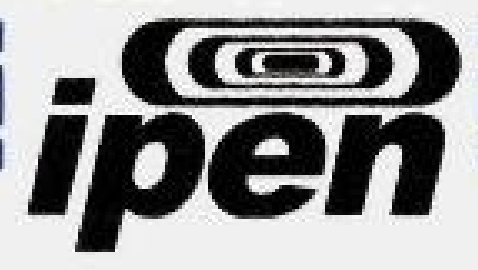

AUTARQUIA ASSOCIADA À UNIVERSIDADE DE SÃO PAULO

\author{
PARQUES TECNOLÓGICOS \\ PROPONDO UM MODELO CONCEITUAL \\ PARA REGIŐES URBANAS \\ O PARQUE TECNOLÓGICO dE SÃo PAULO
}

DESIREEE MORAES ZOUAIN

Tese apresentada como parte dos requisitos para obtenção do Grau de Doutor em Ciências na Area de Tecnologia Nuclear-Aplicaçס̃es.

Orientador:

Dr. José Roberto Rogero

Co-Orientador:

Dr. Guilherme Ary Plonski 
INSTITUTO DE PESQUISAS ENERGÉTICAS E NUCLEARES

Autarquia associada à Universidade de São Paulo

PARQUES TECNOLÓGICOS - PROPONDO UM MODELO CONCEITUAL PARA REGIÕES URBANAS - O PARQUE TECNOLÓGICO DE SÃO PAULO

DESIRÉE MORAES ZOUAIN

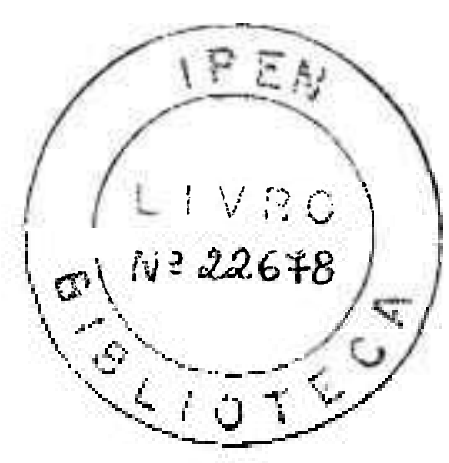

Tese apresentada como parte dos requisitos para obtenção do Grau de Doutor em Ciências na Área de Tecnologia Nuclear - Aplicações.

Orientador:

Dr. José Roberto Rogero

Co-orientador:

Dr. Guilherme Ary Plonski

SÃO PAULO

2003 
Aos queridos Edson, Luciana e Daniella, que me auxiliaram a transformar um sonho em doce realidade. 


\section{Agradecimentos}

Agradeço aos Professores José Roberto Rogero e Guilherme Ary Plonski pela atenção e segura orientação.

Agradeço ao Dr. Cláudio Rodrigues, Superintendente do IPEN, por estimular e apoiar o desenvolvimento desta pesquisa.

Agradeço a Dra. Conceição Vedovello que, com sua grande experiência no tema, auxiliou-me a aprimorar minha pesquisa bibliográfica e o processo da pesquisa de campo.

Agradeço às pessoas que gentilmente responderam ao instrumento de pesquisa e às entrevistas, permitindo o aprofundamento dos conhecimentos a respeito das experiências nacionais e internacionais, algumas ainda muito recentes, de parques científicos e tecnológicos.

Agradeço ao Dr. Samuel Jerozolimski que contribuiu para que eu pudesse conhecer melhor o movimento de parques tecnológicos e incubadoras tecnológicas em Israel.

Agradeço aos meus colegas da Assessoria de Relações Institucionais do IPEN que souberam compreender e apoiar-me durante o desenvolvimento desta pesquisa.

Finalmente, agradeço ao meu marido Edson, grande companheiro, pela paciência, carinho e compreensão durante todo o período de realização desta pesquisa. 
"Nunca ande pelo caminho traçado, pois ele conduz somente até onde os outros foram."

(Alexander Graham Bell) 


\title{
PARQUES TECNOLÓGICOS - PROPONDO UM MODELO CONCEITUAL PARA REGIÕES URBANAS - O PARQUE TECNOLÓGICO DE SÃO PAULO
}

\author{
Desirée Moraes Zouain
}

\section{RESUMO}

Este trabalho propõe um modelo conceitual de Parque Tecnológico adaptado aos requisitos da sociedade do conhecimento, contextualizado para regiões urbanas, de média a densamente povoadas, ou metropolitanas. O modelo é particularizado para a cidade de São Paulo, focalizando o entorno da Cidade Universitária - campus da Universidade de São Paulo, na capital, região onde se encontra uma grande densidade de instituições de pesquisa e organizações de apoio ao desenvolvimento científico e à inovação tecnológica, tais como: o Instituto de Pesquisas Energéticas e Nucleares (IPEN), o Instituto de Pesquisas Tecnológicas (IPT), o Instituto Butantã e o Centro Incubador de Empresas Tecnológicas (CIETEC). O modelo considera a alteração da vocação econômica da cidade de São Paulo, a mudança física de empresas de grande porte de setores tradicionais, a alta taxa de desemprego e o mercado extremamente competitivo, fatos esses que são desafios para a implementação de políticas que possibilitem a substituição de atividades declinantes por atividades nascentes, mais competitivas e que auxiliem na atração de investimentos para a cidade. Para apoiar o desenvolvimento do modelo, é construído um panorama de experiências nacionais e estrangeiras em parques tecnológicos, detalhando aspectos estratégicos, estruturais, gerenciais e operacionais, tendo sido analisadas sete experiências nacionais e três experiências internacionais, por meio da aplicação de um instrumento de pesquisa e entrevistas. O modelo conceitual é elaborado tomando por base três pilares que se apresentam importantes para o sucesso das experiências analisadas durante a pesquisa de campo, a saber: a dinâmica das relações entre os atores envolvidos, a inserção e relação com o meio urbano e as características das empresas e respectivos estágios de desenvolvimento. O modelo proposto reúne quatro grupos de atividades no seu contexto: as atividades de um centro incubador de empresas tecnológicas; as atividades das empresas graduadas ou maduras e micro e pequenas e médias empresas, externas ao sistema, baseadas no conhecimento, bem como instalações de pesquisa e desenvolvimento de grandes corporações em parceria com instituições de pesquisa instaladas na região, e as atividades do Parque Tecnológico propriamente dito, entidade que suporta as ações previstas no modelo. $O$ presente modelo propõe um passo além da idéia de estruturação de um parque urbano, prevendo um núcleo gestor e coordenador, composto por algumas de suas estruturas organizacionais, e a disseminação desse parque na cidade, permitindo irradiar ações coordenadas no meio urbano. 


\title{
TECHNOLOGY PARKS - BUILDING UP A MODEL TO URBAN REGIONS - THE TECHNOLOGY PARK OF SAO PAULO
}

\author{
Desirée Moraes Zouain
}

\section{ABSTRACT}

A conceptual model of Technology Park is established, adapted to the knowledge society requirements. The focus is on medium and highly dense population areas and global megacities, mainly in developing countries. The model is particularized to the Sao Paulo city and the neighbourhood of the University of Sao Paulo campus. This region has a high density of research institutions and other organizations that support scientific, technology and innovation activities; among these organizations are: the Institute for Nuclear and Energy Research (IPEN), the Institute for Technology Research (IPT), the Butanta Institute and the Incubator Center for Technology Enterprises (CIETEC). The model considers the changes in the economic vocation of the Sao Paulo city, the removal of traditional industry sectors organizations from the region, the unemployment rates and the highly competitive global market. These challenges ask for policies that can attract new economic activities, more competitive in the global market, and new investors. To support the research activities it is applied a questionnaire and interviews to seven national and three international technology parks experiences. The conceptual model is based on three main aspects which are considered by these experiences very important to the success of the technology parks, as follows: the dynamics of the players relation, the urban intervention of the project and the companies characteristics and development stages. The proposed model concerns to four groups of activities: the technology incubator center activities; the graduate or mature companies from the incubator center or other micro, small or medium knowledge based companies, from outside the system; the cooperative research activities among private organizations and research institutions; the Technology Park services and managing activities. This model innovates concerning the conception of a managing and coordinator core, located inside the University campus, and by the dissemination and irradiation of the Technology Park activities and benefits to the city, forming innovative clusters and establishing a dense knowledge network. 


\section{SUMẢRIO}

Página

1 INTRODUÇÃO

2 OBJETIVOS E CONTRIBUIÇÕES ORIGINAIS 6

3 REVISÃO DA LITERATURA E FUNDAMENTAÇÃO TEÓRICA 10

3.1 Os desafios da Sociedade (economia) do conhecimento 10

$\begin{array}{ll}3.2 \text { Os efeitos da globalização dos mercados } & 17\end{array}$

3.3 Os parques científicos e tecnológicos 31

3.3.1 Apresentação de definições e terminologias 32

3.3.2 Principais organizações internacionais que agrupam e formam 42 redes de parques científicos e tecnológicos e principais indicadores mundiais relativos ao movimento

3.3.3 Breve revisão da experiência do Vale do Silício (Califórnia Universidade de Stanford)

3.3.4 Aspectos positivos e negativos do movimento de parques científicos e tecnológicos

3.4 Desenvolvimento urbano e as megacidades globais: as características regionais da cidade de São Paulo e da região da Cidade Universitária

3.4.1 Mega cidades globais e seus impactos na prosperidade das nações

3.4.2 A classificação da rede urbana brasileira e o processo de configuração das metrópoles no Brasil

3.4.3 Caracterização das regiões metropolitanas do Estado de São Paulo; os movimentos urbanos na Grande São Paulo

3.4.4 As regiões vizinhas à Cidade Universitária - características gerais e perspectivas

4 METODOLOGIA DA PESQUISA

4.1 Método da pesquisa

4.1.1 Bases lógicas da pesquisa

4.1.2 Complementação do paradigma hipotético-dedutivo com o paradigma holístico-interpretativo 
5.1 Consolidação dos resultados da pesquisa de campo

Página

6 ANÁLISE E DISCUSSÃO DOS RESULTADOS

6.1 Caracterização das experiências analisadas

6.1.1 Pólo de Informática de São Leopoldo

6.1.2 Parque de Desenvolvimento Tecnológico - PADETEC

6.1.3 Porto Alegre Tecnópole

6.1.4 Londrina Tecnópolis

6.1.5 Porto Digital

6.1.6 Pólo de Alta Tecnologia de Campinas

6.1.7 Parque Tecnológico do Rio de Janeiro

6.1.8 Kyriat Weizmann Science Park

6.1.9 Parque Tecnológico de Andalucía S.A

6.1.10 TAGUSPARQUE S.A.

6.2 Discussão e interpretação dos resultados

7.1 As questões da pesquisa e a concepção de parques científicos e tecnológicos urbanos

7.2 As características e estruturas de negócios inseridas no modelo e suas relações com os atores envolvidos

7.2.1 Conceito 1: a dinâmica das relações entre os atores

7.2.2 Conceito 2: Estágios de desenvolvimento das empresas e respectivas formas de instalação e permanência no parque

7.2.3 Conceito 3: Disseminação das ações do parque no meio urbano

7.3 Estruturas que integram a organização

7.4 Propostas para o Núcleo do Parque Tecnológico de São Paulo

8.1 Primeira assertiva: a proximidade entre os atores envolvidos

8.1.1 A proximidade dos atores como fator de sucesso dos parques tecnológicos

8.1.2 Discussão sobre a primeira assertiva

8.2 Segunda assertiva: relações com o meio urbano e aos aspectos de desenvolvimento regional 
Página

8.2.1 Evolução tecnológica e a questão urbana 195

8.2.2 Localização de parques tecnológicos e sua inserção no tecido urbano

8.2.3 Discussão sobre a segunda assertiva

8.3 Terceira assertiva: a dinâmica das relações entre os atores envolvidos e às estruturas que promovem essas relações

8.3.1 Modelos ternários e "habitats" de inovação

8.3.2 Discussão sobre a terceira assertiva

9 CONCLUSÕES E RECOMENDAÇÕES 


\section{LISTA DE TABELAS}

TAB. 3.1 - Indicadores quantitativos da emergência da Sociedade do Conhecimento - aspectos gerais

TAB. 3.2 - Indicadores da emergência da Sociedade do Conhecimento 15 no Brasil

TAB. 3.3 - Aspectos de consenso que caracterizam o processo de globalização

TAB. 3.4 - O advento dos "Estados-regiões"

TAB. 3.5 - Principais definições adotadas para Parques Científicos e Tecnológicos

TAB. 3.6 - Características dos modelos de Parques Tecnológicos classificação histórico-geográfica de Sanz

TAB. 3.7 - Experiências selecionadas por Benko e Castells\&Hall 38

TAB. 3.8 - Dados estatísticos referentes à IASP

TAB. 3.9 - Associações Nacionais e Regionais, no mundo, catalogadas pela IASP

TAB. 3.10 - Principais indicadores do movimento de parques científicos e tecnológicos no mundo

TAB. 3.11 - Parques Científicos e Tecnológicos - "Granjas do Conhecimento"

TAB. 3.12 - Parques Científicos e Tecnológicos - balanço entre aspectos positivos e negativos

TAB. 3.13- Maiores aglomerados urbanos do mundo em 2000

TAB. 3.14 - Características das Regiões Metropolitanas e São Paulo

TAB. 3.15 - Plano Metropolitano da Grande São Paulo 1994/2010 -

Diretrizes Metropolitanas

TAB. 3.16 - Comparativo da evolução do número e do faturamento de empresas sediadas na Grande São Paulo, na última década

TAB. 3.17 - Principais dados/indicadores da infra-estrutura científicotecnológica de São Paulo

TAB. 3.18 - Características das Subprefeituras que envolvem a Cidade 
TAB. 4.1 - Aplicação do método científico hipotético-dedutivo e da pesquisa social ao planejamento e execução das atividades deste trabalho

TAB. 5.1 - Dados cadastrais das experiências analisadas na pesquisa de campo

TAB. 5.2 - Matriz lógica das experiências selecionadas (nacionais e internacionais)

TAB. 5.3 - Dimensão (A) - localização de Parques de C\&T

TAB. 5.4 - Dimensão (B) - contexto sócio-econômico, político e cultural da região

TAB. 5.5 - Dimensão (C) - Legislação de apoio

TAB. 5.6 - Dimensão (D) - modelo e estrutura adotado

TAB. 5.6.1 - Objetivos estratégicos

TAB. 5.6.2 - Características do modelo adotado

TAB. 5.7 - Dimensão $(E)$ - gerenciamento do parque

TAB. 5.8 - Dimensão (F) - Aspectos financeiros, incentivos ao investimento

TAB. 5.9 - Dimensão (G) - Marketing e comunicação

TAB. 5.10 - Dimensão $(H)$ - Formação e treinamento

TAB. 5.11 - Dimensão (l) - Resultados obtidos e avaliação de impacto na região

TAB. 6.1 - Matriz-resumo das principais contribuições advindas da pesquisa de campo

TAB. 6.2 - Consolidação dos resultados da apuração da pesquisa de campo, interpretação e comentários - conclusão referente à pesquisa de campo

TAB. 7.1 - Pressupostos que norteiam os projetos de parques científicos 168 e tecnológicos urbanos e as questões de pesquisa

TAB. 7.2 - Matriz Lógica proposta para o Parque Tecnológico de São Paulo 


\section{LISTA DE FIGURAS}

FIG. 3.1 - Apresentação de uma forma gráfica para exprimir a "espiral

Página do conhecimento"

FIG. 3.2 - O "diamante" de Porter $(1989,0.88)$ - determinantes da 22 vantagem nacional

FIG. 3.3 - Quatro etapas do desenvolvimento competitivo nacional 23

FIG. 3.4 - Economia impulsionada pela inovação 24

FIG. 3.5 - Novas tendências de ocupação na cidade de São Paulo 67

FIG. 4.1 - Dimensões consideradas na pesquisa de campo 77

FIG. 7.1 - Modelo conceitual do Parque Tecnológico 175

FIG 7.2 - Diagrama dos estágios que apóiam o crescimento do negócio 182

FIG. 7.3 - Estruturas que compõem o modelo conceitual do Parque 190 Tecnológico 


\section{INTRODUÇÃO}

"We are at the dawn of a new industrial order. We are leaving behind a world in which scale, efficiency and replication were everything. We are taking our first tentative steps into a world where imagination, experimentation, and agility are, if not everything, at least the essential catalysts for wealth creation. Resource allocation worked fine for the old world, but companies need something more, and quite different, if they are to capture their fair share of wealth in the new world." (Gary Hamel) ${ }^{1}$

O fenômeno da globalização dos mercados, que vem se desenvolvendo de forma acelerada, introduz novas demandas e desafios com relação a políticas e a mecanismos que promovam a geração e a disseminação do conhecimento como base para a competitividade empresarial e o crescimento econômico (Albagli, 1999; Cassiolato \& Lastres, 1999; Salomão, 1998; Terra, 2000).

Dentre esses mecanismos, encontram-se sistemas e formas de cooperação que visam o estabelecimento de relações profícuas e duradouras entre as universidades e instituições de pesquisa com o setor empresarial, permitindo sua constante renovação e capacitação para a competitividade.

Vários estudos abordam, na atualidade, o advento de uma dessas formas de cooperação que se traduz nos chamados Parques Científicos $e$ Tecnológicos. Esses modelos têm mostrado resultados positivos no âmbito internacional, tanto no que se refere às expectativas dos órgãos governamentais, coordenadores de políticas públicas, que têm como principal objetivo o desenvolvimento regional, bem como das empresas que a eles se associam.

De acordo com diversos autores (Parejo, 1992, Medeiros, 1996a, 1996b; Sanz, 1998; Spolidoro, 1997; Spolidoro, 1999), os parques científicos e tecnológicos podem ser considerados importantes instrumentos para 0 desenvolvimento regional e, de forma geral, apresentam as seguintes características:

\footnotetext{
${ }^{1}$ HAMEL, G. Bringing Silicon Valley Inside. Harvard Business Review, p. 71-84, SeptemberOctober 1999.
} 
> São iniciativas componentes de políticas públicas para incentivo à inovação nas empresas; contribuem para o aumento da competitividade das empresas regionais ou em sua área de influência;

> São iniciativas impulsionadoras para a criação de empresas inovadoras, intensivas em conhecimento e novas tecnologias, geralmente "spin-off" de instituições de pesquisa e ensino, que se situam nas proximidades;

> São iniciativas com base em áreas físicas, onde as empresas inovadoras ou intensivas em conhecimento estão localizadas, que podem ser delimitadas ou disseminadas na cidade, tendência esta mais inovadora;

> Promovem a interação dessas empresas com instituições de ensino, pesquisa, desenvolvimento tecnológico e de informação, localizadas em um campus de universidade ou em regiões que acumulam instituições dessa natureza;

> Auxiliam a evitar a degradação do tecido urbano, revitalizando antigas áreas resultantes do paradigma da Sociedade Industrial;

$>$ Possuem uma entidade gestora para atuar como facilitadora nas questões imobiliárias, de entrosamento entre as empresas, para fins de divulgação, para estimular ações compartilhadas de obtenção de financiamentos, de gestão da infra-estrutura comum, de transferência de tecnologia, para estabelecimento de redes com outras iniciativas semelhantes, entre outras ações.

A formatação ou configuração de parques tecnológicos no Brasil, embora representem experiências muito jovens ou ainda em projeto ou em implantação, caracteriza-se por empresas que estão reunidas num mesmo local, dentro do campus da universidade, ao lado deste ou em uma área próxima. Existe uma entidade coordenadora concebida para facilitar a integração universidadeempresa e para gerenciar o uso das instalações existentes. Estão disponíveis, para venda ou locação, terrenos ou prédios, os quais abrigam uma incubadora ou condomínio de empresas.

No Brasil, pesquisas sobre a ocorrência deste fenômeno indicam a concepção do parque tecnológico como a forma mais completa de cooperação universidades/centros de pesquisa - empresa, pois concentra os seguintes 
benefícios (Medeiros, 1992; Medeiros, 1996a; Stal, 1998): a proximidade espacial entre todos os atores deste processo de cooperação; a presença de institutos de pesquisa e ensino; a aglomeração de empresas envolvidas diretamente com a tecnologia disponibilizada pelas instituições de pesquisa; a captação de projetos de inovação tecnológica conjuntos entre o setor privado $e$ as instituições de pesquisa, resultantes de ações governamentais de caráter estratégico, visando o desenvolvimento local; a disponibilidade de uma estrutura organizacional, formal ou informal; a presença de incubadoras de empresas que dispõem de infraestrutura física e administrativa bem como colocam à disposição dos incubados diversos senviços.

Embora existam, na atualidade, muitos trabalhos sobre os parques científicos e tecnológicos, são observadas lacunas na literatura no que tange aos estudos e pesquisas sobre parques tecnológicos em centros urbanos ou em regiões metropolitanas, particularmente em países em desenvolvimento e no Brasil (as experiências e estudos são numerosos, neste tema, porém para clusters em municípios do interior ou em regiões fora dos grandes centros urbanos).

No contexto da cidade de São Paulo, em 1998 começaram a surgir no âmbito do Instituto de Pesquisas Energéticas e Nucleares (IPEN), do Instituto de Pesquisas Tecnológicas (IPT) e da Universidade de São Paulo (USP) discussões sobre a possibilidade de implantar um Parque Tecnológico na Cidade de São Paulo, nas cercanias da Cidade Universitária. Esta iniciativa se originou a partir do amadurecimento de algumas ações isoladas existentes Cidade Universitária tais como: a implantação do CIETEC (Centro Incubador de Empresas de Base Tecnológica), o projeto da Incubadora de Cooperativas Populares, a Incubadora de Empresas de Biotecnologia e a instalação de diversas associações setoriais. Associado a isto, estava o reconhecimento das mudanças que estão ocorrendo com relação à alteração da vocação econômica da cidade de São Paulo. A mudança física de empresas de grande porte de setores tradicionais, a alta taxa de desemprego e o mercado extremamente competitivo se tornaram desafios para a implementação de políticas públicas que possibilitassem a substituição de atividades declinantes por atividades nascentes, mais competitivas e que auxiliassem na atração de investimentos para a cidade. 
A partir das discussões iniciais, essas entidades estruturaram uma proposta à Secretaria de Ciência, Tecnologia e Desenvolvimento Econômico e Turismo do Estado de São Paulo (SCTDET/SP) que consistia na implantação de um Parque Tecnológico como forma de contribuir com a política de atração de investimentos de qualidade; contribuir para a alteração da vocação econômica da região metropolitana de São Paulo; criar novas perspectivas para a revitalização urbana das cercanias da Cidade Universitária; intensificar a interação da Universidade e dos Institutos de Pesquisa localizados no campus com empresas criando uma motivação para a participação dos pesquisadores do campus; estimular a ampliação dos empreendimentos bem sucedidos a partir das incubadoras do campus; contribuir para o incremento de exportações com alto valor agregado; auxiliar na alteração do modelo "emprego" para "ocupação e renda".

A partir do reconhecimento dos pressupostos apresentados, a SCTDET/SP capitaneou esforços em torno de ações que visavam gerar um - modelo de referência atualizado para parques tecnológicos urbanos.

Em decorrência da importância estratégica colocada sobre o tema, surge a idéia de desenvolver esta pesquisa, como forma de contribuir com a formulação de um modelo conceitual de parque tecnológico urbano bem como identificar e analisar experiências, preferencialmente já em implantação ou operação, nacionais e internacionais.

A presente pesquisa é dividida em duas fases: a primeira tem por objetivo construir um panorama de experiências nacionais e estrangeiras em parques tecnológicos, detalhando aspectos estratégicos, estruturais, gerenciais e operacionais, principais impactos e resultados, sendo analisadas sete experiências nacionais e três experiências internacionais previamente selecionadas e que concordaram em participar da pesquisa. A segunda parte caracteriza-se pelo desenvolvimento de um modelo conceitual de parque tecnológico para regiōes urbanas adaptado aos requisitos da sociedade do conhecimento, sendo o mesmo, em seguida, particularizado para a região da cidade de São Paulo. 
O texto está estruturado em nove capítulos, a saber:

$>$ Nos capítulos 1 e 2, introdução e objetivos, são apresentadas a contextualização da pesquisa, a importância do problema identificado, a comparação deste trabalho com outros similares, os pressupostos, os objetivos, as questões da pesquisa e suas contribuições originais;

$>$ No capítulo 3 são apresentadas a revisão da literatura e a fundamentação teórica;

No capítulo 4 é apresentada a metodologia da pesquisa;

$>$ Nos capítulos 5 e 6 são apresentados, analisados e discutidos os resultados da primeira fase da pesquisa e identificados subsídios para a segunda fase da pesquisa;

> Nos capítulos 7 e 8 são apresentadas a formulação do modelo conceitual, a discussão sobre o modelo e suas limitações;

$>$ No capítulo 9 são apresentadas as conclusões e recomendações.

A estrutura do texto conta ainda com as referências bibliográficas e com uma bibliografia recomendada. 


\section{OBJETIVOS E CONTRIBUIÇÕES ORIGINAIS}

\section{Os pressupostos desta pesquisa são:}

De caráter amplo:

- O advento do mercado global insere no contexto da competitividade das empresas uma maior demanda por produtos e serviços de alta qualidade e intensivos em conhecimento e inovação; o mercado globalizado é característico da economia do conhecimento;

- Como resposta ao paradigma da economia do conhecimento, são essenciais as políticas públicas e estratégias que promovam, entre outras ações, a competitividade das empresas e a sinergia entre os diversos setores da sociedade em prol do desenvolvimento econômico e do bem estar social;

- As megalópoles mundiais (com mais de 10 milhões de habitantes), estando São Paulo entre as cinco maiores cidades do mundo (Tóquio, Cidade do México, Nova York e Bombaim), demandam políticas públicas que possam solucionar o crescimento desordenado, criar soluções de inclusão social, atraídas para as cidades pelas oportunidades aparentes, revitalizar a interação entre as classes sociais no ambiente urbano, criar novas formas de atração de investimentos e capital em ações baseadas no conhecimento, e que contenham alto índice de consciência ambiental.

De caráter específico:

- Na região da cidade de São Paulo, e municípios adjacentes que compõem a região metropolitana, particularmente na região da Cidade Universitária, existe uma alta densidade de instituições de ensino e pesquisa, com pessoas altamente qualificadas, atuantes na fronteira do conhecimento ou na inovação tecnológica, com características adequadas para a estruturação de iniciativas tais como parques científicos e tecnológicos; 
- Na região do entorno do campus da Universidade de São Paulo observa-se várias áreas degradadas que podem ser revitalizadas pela implantação de iniciativas tais como parques científicos e tecnológicos e suas ações disseminadas no meio urbano;

- Existem dificuldades importantes para promover a sinergia entre os atores demandantes e ofertantes de conhecimento e inovação tecnológica;

- Iniciativas tais como os "habitats" de inovação, entre estes os parques científicos e tecnológicos, são mecanismos que facilitam essa sinergia, proporcionando um ambiente de fertilização cruzada.

Referentes aos modelos conceituais de parques científicos e tecnológicos em meio urbano:

- São iniciativas que apóiam o desenvolvimento regional, dinamizando a atividade econômica local por meio de:

- formação e crescimento de empresas,

- aumento das atividades comerciais e de exportação baseadas em produtos e serviços com alto valor agregado,

- geração de emprego e renda;

- São iniciativas que envolvem empreendimentos imobiliários que possam oferecer a infra-estrutura necessária e que tornam compatível esta estrutura com o ambiente urbano e seus planos de desenvolvimento e diretor;

- São iniciativas que incorporam em seus planos o apoio ao desenvolvimento sustentável e a recuperação de áreas degradadas ou economicamente deprimidas nas cidades;

- São iniciativas que pressupõem uma base científica e tecnológica de apoio; que tentam estabelecer ou otimizar, por meio de estruturas organizacionais formais ou informais, a disseminação do conhecimento. 


\section{Proposições deste estudo:}

Objetivo superior:

- Adequar e aprimorar modelos de "habitats" de inovação, no caso parques tecnológicos dimensionados para as peculiaridades de grandes centros urbanos em regiōes emergentes, de modo a incentivar a sinergia entre os atores e a possibilitar impactos sociais e econômicos positivos para essas regiões.

Objetivos imediatos:

- Identificar e compreender os fatores críticos de sucesso em iniciativas nacionais e internacionais caracterizadas como parques científicos e tecnológicos, implantados em regiões urbanas de média a densamente povoadas;

a Caracterizar um modelo conceitual para parque tecnológico disseminado em meio urbano, particularizando o modelo para um Parque Tecnológico na cidade de São Paulo.

\section{Contribuições Originais da Proposição do Trabalho:}

- A pesquisa propõe a formulação de um modelo conceitual de parque tecnológico em meio urbano, particularizando para o Parque Tecnológico de São Paulo, como instrumento de apoio a políticas públicas para o desenvolvimento de regiões urbanas. Ao contrário dos trabalhos identificados na pesquisa bibliográfica e estudos exploratórios realizados, esta pesquisa não se restringe a um estudo de caso, mas sim elabora um modelo conceitual que auxilia os gestores na condução de projetos de parques tecnológicos urbanos;

- A pesquisa contribui para suprir a carência de estudos e pesquisas sobre parques científicos e tecnológicos urbanos, particularmente em países em desenvolvimento.

São as seguintes as questões da pesquisa:

- Como um modelo de parque tecnológico pode contribuir para proporcionar alternativas, baseadas no conhecimento e na inovação tecnológica, para o desenvolvimento das regiões urbanas, particularmente para a cidade de São Paulo?

- Como um modelo de parque tecnológico pode aproveitar a alta densidade de instituições de ensino e pesquisa existente na região, 
de forma a contribuir com iniciativas "estruturantes"1 para a organização da sociedade local, frente aos desafios do novo paradigma do conhecimento?

- Que características são recomendadas para um parque tecnológico urbano, como instrumento para estimular a sinergia entre os atores demandantes e ofertantes de conhecimento e inovação tecnológica?

1 "Essas iniciativas se caracterizam por serem intervenções localizadas e especificas, terem o poder de modificar um conjunto de grande amplitude da realidade a partir da ação sobre seus aspectos parciais, e serem formuladas com base num conjunto de axiomas definidos a partir das características das transiçōes de paradigmas, do novo paradigma e do domínio considerado." (Spolidoro, 1997) 


\section{REVISÃO DA LITERATURA E FUNDAMENTAÇÃO TEÓRICA}

Neste capítulo são apresentados os aspectos relativos à revisão da literatura e à fundamentação teórica que permitiram o desenvolvimento do tema da pesquisa.

O capítulo foi organizado em temas relacionados aos pressupostos e objetivos deste estudo, de forma a contextualizar a pesquisa, a saber: os desafios da sociedade (economia) do conhecimento, os efeitos da globalização dos mercados, os parques científicos e tecnológicos, o desenvolvimento urbano e as megacidades globais com foco nas características regionais da cidade de São Paulo e a região da Cidade Universitária.

Para construir a argumentação foi adotado o seguinte método: são identificados autores e estudiosos dos temas abordados; em seguida, são analisados pensamentos desses estudiosos que contribuem para a construção da argumentação, sendo esses pensamentos expressos e organizados na forma de tabelas ou comentários; ao final de cada tema abordado, são apresentados os comentários e conclusões desta autora sobre cada aspecto abordado. Nos itens relativos a parques científicos e tecnológicos e às características regionais, os comentários e conclusões estão disseminados no texto.

\subsection{Os desafios da Sociedade (economia) do conhecimento}

"O conhecimento está rapidamente se transformando no único fator de produção, deixando de lado capital e mão-de-obra. Pode ser prematuro (e certamente presunçoso) chamar a nossa sociedade de "sociedade de conhecimento"; por enquanto, temos somente uma economia do conhecimento."

(Peter Drucker) ${ }^{1}$

"O conhecimento é ensejado pelo estabelecimento de relações de cooperação entre entes... que se reconhecem distintos, mas que percebem o potencial de desenvolvimento existente numa relação marcada pela reciprocidade... O desconhecimento, por sua vez, resulta do tratamento dos interlocutores não como potenciais parceiros, mas como objetos a serem explorados oportunisticamente, a partir dos quais se pode obter vantagens unilaterais."

(Guilherme Ary Plonski)

\footnotetext{
${ }^{1}$ DRUCKER, P. Sociedade pós-capitalista. Tradução de Nivaldo Montingelli Jr. São Paulo: Pioneira; São Paulo: Publifolha, 1999, p. 5. Título original: Post-capitalist society.

${ }^{2}$ PLONSKI,G.A. Questões tecnológicas na sociedade do des(conhecimento). In: SANTOS, L.W.; ICHIKAWA, E.Y.; SENDIN, P.V.; CARGANO, D.F. (Org.) Ciência, tecnologia e sociedade: 0 desafio da interação. Londrina: IAPAR, 2002. p. 83-99.
} 
Entre os pressupostos apresentados no capítulo 2 deste estudo, foram indicados o advento da sociedade (economia) do conhecimento e, como uma de suas características, o mercado globalizado que introduz novas demandas e desafios para as organizações, para a sociedade em geral e para as regiões.

Apresenta-se, portanto, a argumentação referente ao paradigma da sociedade do conhecimento e sua relação com a pesquisa em curso baseando-se nos seguintes princípios e pensamentos de estudiosos do tema:

- A geração e a disseminação do conhecimento como fator de vantagem competitiva e de transformação das sociedades e das organizacōes:

- "a gestão competente do conhecimento é determinante da capacidade das sociedades, regiões, organizações e pessoas lidarem com $o$ ambiente em acelerada transformação $e$ crescente complexidade que caracteriza a passagem do milênio"(Plonski, 2002);

- e, na mesma linha: a geração de conhecimento e sua disseminação e incorporação em novas tecnologias e produtos é fonte segura para alcançar vantagem competitiva; no âmbito das empresas essas atividades caracterizam a empresa "criadora de conhecimento" (que tem como negócio a inovação contínua) (Nonaka, 2000);

- A espiral do conhecimento e a inovacão sistemática nas empresas - 0 novo paradigma:

- a "espiral do conhecimento" - "a conversão do conhecimento individual em recursos disponiveis para outras pessoas é a atividade central da empresa criadora de conhecimento" (a conversão do conhecimento tácito em conhecimento explícito ${ }^{3}$ ) (FIG. 3.1 apresenta uma forma gráfica para introduzir o processo da "espiral do conhecimento de Nonaka") (Nonaka, 2000);

\footnotetext{
${ }^{3}$ Para Nonaka (2000), o conhecimento tácito consiste em habilidades técnicas (know-how) e em uma dimensão cognitiva (envolve modelos mentais, crenças e perspectivas de difícil manifestação), ambas as dimensões de difícil especificação e disseminação; o conhecimento explícito é formal e sistemático e facilmente comunicado. O processo de disseminação do conhecimento para a promoção da inovação sistemática tem um estágio nevrálgico que é a transformação do conhecimento tácito em explícito, ou seja, sua padronização e, em seguida, o desenvolvimento de novos conhecimentos tácitos decorrentes das experiências absorvidas no processo.
} 
- e, na mesma linha, Lundvall (2000) também comenta sobre conhecimento como informação ou como habilidade humana (conhecimento tácito):

"The most important dividing line in the analysis of knowledge and learning goes between knowledge as information and knowledge as tacit skills. Information is knowledge that has been reduced into bits and than can be transmitted between localities and agents through telecommunications networks. Tacit knowledge is constituted by skills and routines embodied in people and embedded in organizations." (Lundvall, 2000a)

- o "conhecimento aplicado ao conhecimento" - "o conhecimento está hoje sendo aplicado, de forma sistemática e determinada, para definir que novo conhecimento é necessário, se ele é viável e o que precisa ser feito para torná-lo eficaz...ele está sendo aplicado à inovação sistemática ("revolução gerencial"s); (Drucker, 1999);

- Indicadores da sociedade do conhecimento e a situação brasileira:

- Em seu livro "Gestão do Conhecimento - o grande desafio empresarial", Terra (2000) apresenta como indicadores quantitativos da emergência da Sociedade do Conhecimento: “a importância da inovação tecnológica para o crescimento econômico e a competitividade empresarial" (vide TAB. 3.1); "a evolução dos setores de informática e telecomunicações" (vide TAB. 3.1); "a importância relativa dos ativos intangíveis" (vide TAB. 3.1); "os impactos econômicos e sociais dos niveis de educação e qualificação profissional" (vide TAB. 3.1);

- Ainda citando Terra (2000), particularizando sua análise para a situação brasileira, o autor apresenta fatos e dados que são indicativos dos aspectos relativos à emergência da sociedade do conhecimento no Brasil e de suas condições e óbices para alavancar a competitividade baseada no conhecimento (vide

\footnotetext{
4 Para Drucker (1999), "Fornecer conhecimento para descobrir como o conhecimento existente pode ser mais bem aplicado para produzir resultados é...aquilo que entendemos por gerência... Esta terceira mudança na dinâmica do conhecimento pode ser chamada de "Revolução Gerencial". Peter Drucker, resgata a concepção de "gerência" como uma função genérica de todas as organizações - "é o órgão genérico da sociedade do conhecimento".
} 
TAB. 3.2 onde se encontram discriminados alguns indicadores apresentados pelo autor).

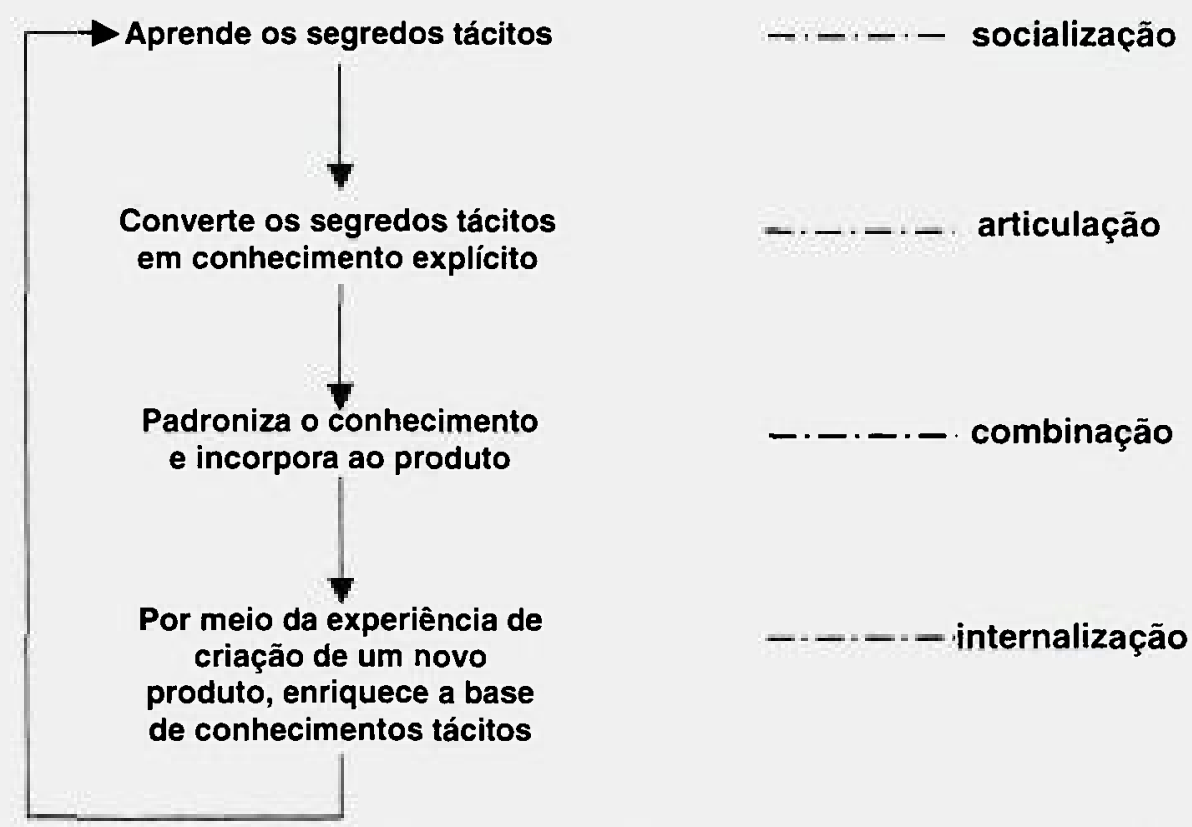

FIGURA 3.1: Apresentação de uma forma gráfica para exprimir a "espiral do conhecimento" de Nonaka.

TABELA 3.1 - Indicadores quantitativos da emergência da Sociedade do Conhecimento - aspectos gerais (Terra, 2000) ${ }^{5}$

\begin{tabular}{|c|c|}
\hline $\begin{array}{c}\text { Sinais quantificáveis da } \\
\text { Sociedade do } \\
\text { Conhecimento } \\
\end{array}$ & Indicadores mais significativos \\
\hline $\begin{array}{l}\text { "A importância da inovação } \\
\text { tecnológica para o } \\
\text { crescimento econômico e a } \\
\text { competitividade } \\
\text { empresarial." }\end{array}$ & $\begin{array}{l}\text { "A inovação tecnológica tem sido responsável por } \\
\text { cerca de } 70 \% \text { do crescimento econômico e, talvez, } \\
\text { por entre } 80 \text { a } 90 \% \text { dos ganhos de produtividade;" } \\
\text { "No conjunto dos países da OCDE, mais de } 50 \% \text { do } \\
\text { PIB está baseado em setores intensivos em } \\
\text { conhecimento;" } \\
\text { "A participação dos setores high-tech no total das } \\
\text { exportações cresceu de cerca de } 16 \% \text { em } 1970 \text { para } \\
\text { cerca de } 26 \% \text { em } 1993 ; " \\
\text { "Entre } 1995 \text { e } 1998 \text { o setor high-tech foi responsável } \\
\text { por } 35 \% \text { do crescimento do PIB americano. Os } \\
\text { preços nesse setor vêm caindo a uma taxa anual de } \\
7 \% \text { e contribuindo para a manutenção de um baixo } \\
\text { índice inflacionário, na década de } 1990, \text { nos EUA;" } \\
\text { "Vários estudos apontam para taxas privadas de } \\
\text { retorno sobre investimentos em P\&D entre } 20 \text { e } 30 \%\end{array}$ \\
\hline
\end{tabular}

${ }^{5} \mathrm{~A}$ composição desta tabela foi feita a partir de uma seleção de indicadores apresentados por Terra (2000), em seu livro "Gestão do Conhecimento - o grande desafio empresarial", às páginas 25 a 31. 


\section{Sinais quantificávejs da Sociedade do Conhecimento}

\section{Indicadores mais significativos}

e para taxas sociais desses mesmos investimentos superiores a $50 \%$;"

- "Estudo com mais de 100 empresas intensivas em tecnologia, nos EUA, mostrou que existia uma forte correlação entre posição de mercado e capacidade inovadora. Quase metade das vendas das empresas líderes era advinda de produtos lançados nos últimos cinco anos."

"A evolução dos setores de informática e telecomunicações."

"...existem...mais de 200 milhões de computadores e mais de 15 bilhões de chips instalados em diversos tipos de máquinas e equipamentos;"

"Em 1997,... os investimentos nos setores de informática chegaram a cerca de US\$ 225 bilhões correspondendo ao dobro dos investimentos nos setores tradicionais" (nos EUA), revertendo a situação anterior onde os investimentos tradicionais em equipamentos industriais eram superiores;"

- "Estima-se que em cerca de uma década a potência do supercomputador de hoje passará a ser a potência do computador de mesa;"

- "O valor de mercado de empresas como Microsoft, Cisco, Lucent e AOL e outras empresas baseadas em tecnologias de software são absolutamente fenomenais."

"A importância relativa dos ativos intangíveis."

"Com o desenvolvimento de um mercado de capitais, não existe mais país rico ou pobre de capital, quando se trata de investimentos...O investimento externo direto no mundo cresceu de US\$112 bilhões para US\$1,023 trilhão entre 1967 e 1987;"

- "O valor de mercado das empresas tende a ser muito maior do que o valor patrimonial, em virtude do valor dos ativos intangiveis (patentes, marcas, etc...); "

"Os impactos econômicos e sociais dos níveis de educação e qualificação profissional."
"Os trabalhadores de fábricas costumavam ter baixíssima qualificação no início da industrialização; hoje, nos EUA, cerca de $16 \%$ já possuem alguma educação de nível superior e $5 \%$ chegam a se graduar;"

"Algumas projeções estimam que, no ano 2000, 85\% de todos os empregos nos EUA e $80 \%$ daqueles na Europa serão intensivos em conhecimento, software e tecnologia e que na Alemanha, em 2010, apenas $10 \%$ dos empregos estarão concentrados no setor manutatureiro;"

- "Estima-se que, em 2006, cerca de $50 \%$ da população americana estará empregada na indústria de informática ou em setores que utilizam intensamente a informática;"

- "A desigualdade de renda... estaria aumentando, em grande parte, por causa do impacto do 


\begin{tabular}{|c|c|}
\hline Sinais quantificáveis da & Indicadores mais significativos \\
\hline & $\begin{array}{l}\text { Conhecimento... cada ano de estudo implica um } \\
\text { aumento de } 2,8 \% \text { nos salários e que a diferença de } \\
\text { salários entre universitários e não-universitários } \\
\text { também está aumentando" (nos EUA); }\end{array}$ \\
\hline $\begin{array}{l}\text { Conclusões do autor (Terra, } \\
\text { 2000): }\end{array}$ & $\begin{array}{l}\text { Na Sociedade do Conhecimento: } \\
\text { - ...a posição de cada indivíduo depende, de forma } \\
\text { crescente, do produto de conhecimento que ele } \\
\text { tenha logrado desenvolver ou construir ao longo de } \\
\text { sua vida." } \\
\text {... "os vários indicadores apresentados para } \\
\text { empresas e países colocam... o conhecimento como } \\
\text { recurso fundamental a ser buscado, desenvolvido, } \\
\text { incentivado e protegido." }\end{array}$ \\
\hline
\end{tabular}

TABELA 3.2 - Indicadores da emergência da Sociedade do Conhecimento no Brasil (Terra, 2000) ${ }^{6}$

\begin{tabular}{|c|c|}
\hline $\begin{array}{c}\text { Aspectos associados à } \\
\text { emergência da Sociedade } \\
\text { do Conhecimento }\end{array}$ & Indicadores mais significativos \\
\hline $\begin{array}{l}\text { Evolução de investimentos } \\
\text { em tecnologia - impactos } \\
\text { no cenário empresarial } \\
\text { brasileiro. }\end{array}$ & 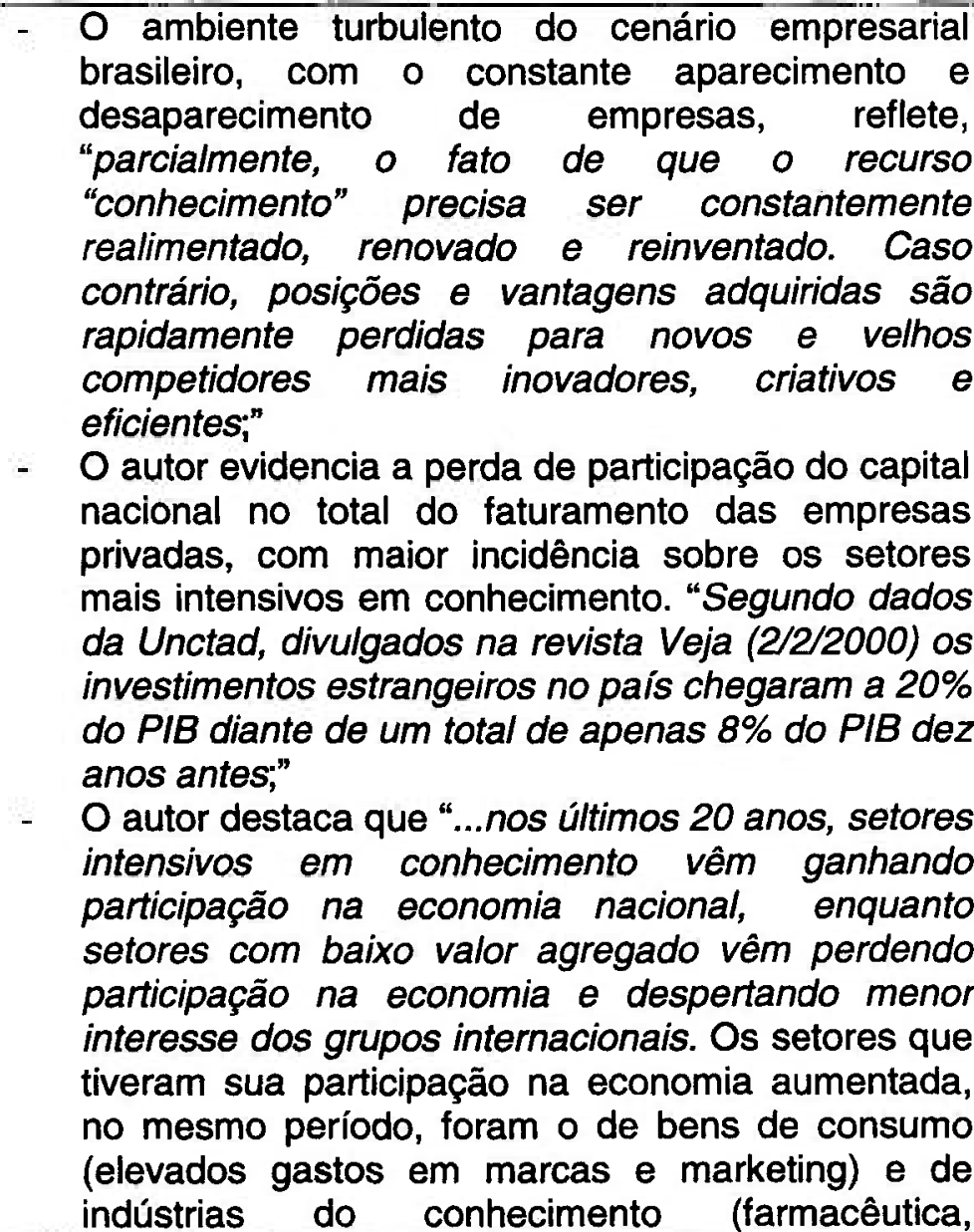 \\
\hline
\end{tabular}

${ }^{6}$ A composição desta tabela foi feita a partir de uma seleção de indicadores apresentados por

Terra (2000), em seu livro, às páginas 31 a 45. 


\begin{tabular}{|c|c|}
\hline $\begin{array}{l}\text { Aspectos associados à } \\
\text { emergência da Sociedade } \\
\text { do Conhecimento }\end{array}$ & Indicadores mais significativos \\
\hline \multirow[b]{2}{*}{$\begin{array}{l}\text { Conclusão do autor (Terra, } \\
2000 \text { ) }\end{array}$} & $\begin{array}{l}\text { computação e eletroeletrônicos); } \\
\text { Entre os setores intensivos em conhecimento que } \\
\text { mais cresceram no país, na década de } 90 \text {, destaca- } \\
\text { se o setor de informática. Este setor ..."dobrou seu } \\
\text { faturamento no período, saindo de US\$ } 7,1 \text { bilhões } \\
\text { em } 1991 \text { para US\$ } 14,1 \text { bilhöes em } 1997 \text {, com } \\
\text { grande destaque para os setores de software e } \\
\text { serviços técnicos;" }\end{array}$ \\
\hline & $\begin{array}{l}\text {...também no Brasil, são os setores intensivos em } \\
\text { tecnologia ou conhecimento que devem sustentar o } \\
\text { crescimento econômico daqui para a frente." }\end{array}$ \\
\hline $\begin{array}{l}\text { A relação educação, } \\
\text { competitividade e } \\
\text { desenvolvimento no Brasil. }\end{array}$ & $\begin{array}{l}\text {..."em comparação com outros paises em } \\
\text { desenvolvimento, a escolaridade média do brasileiro } \\
\text { é muito baixa: } 3,8 \text { anos contra } 8,7 \text { dos argentinos; } \\
7,5 \text { dos chilenos e } 11,0 \text { dos coreanos"; o autor } \\
\text { correlaciona a baixa escolaridade aos baixos } \\
\text { indices de produtividade que o país apresenta; } \\
\text {..."verifica-se que, a exemplo das estatísticas } \\
\text { americanas,... existe também no Brasil uma grande } \\
\text { correlação entre nivel de escolaridade, taxa de } \\
\text { ocupação e rendimento financeiro do } \\
\text { trabalho;...pesquisa da Unesco e da ocDE } \\
\text { envolvendo dados de } 22 \text { países referentes a 1999, } \\
\text { mostra que ... o Brasil apresenta as maiores } \\
\text { diferenças salariais (474\%) entre pessoas com } \\
\text { diploma universitário e aquelas que concluíram } \\
\text { apenas o ensino fundamental." }\end{array}$ \\
\hline $\begin{array}{l}\text { Conclusão do autor } \\
\text { (Terra, 2000) }\end{array}$ & $\begin{array}{l}\text {..."os índices de escolaridade do país ainda se encontram } \\
\text { em patamares bastante baixos, mesmo em comparação } \\
\text { com países com niveis similares de renda." } \\
\text { "O desafio ... não envolve apenas um aumento expressivo } \\
\text { nos investimentos em P\&D, educação, treinamento ou } \\
\text { tecnologia de informação, pois tão ou mais importante é a } \\
\text { produtividade desses investimentos"... }\end{array}$ \\
\hline
\end{tabular}

Concluindo, observa-se que a argumentação enfocada neste item, com relação ao pressuposto apresentado no capítulo 2 relativo ao paradigma da sociedade (economia) do conhecimento, aponta para a necessidade de desenvolvimento de políticas públicas e estratégias que estimulem, entre outras ações, de forma coordenada e produtiva:

- A competitividade das empresas pela gestão do conhecimento, em seu amplo sentido, e pela criação de ambientes organizacionais indutores da inovação tecnológica sistemática; 
- O compartilhamento do conhecimento decorrente das atividades de entidades de ensino e pesquisa e da experiência e visão de mercado das empresas, proporcionando uma sinergia potencialmente criativa e geradora de novas idéias e produtos;

- O aumento dos niveis de escolaridade e conseqüente inclusão social de indivíduos que estão fora do mercado de trabalho, considerando o ambiente da economia do conhecimento.

\subsection{Os efeitos da globalização dos mercados}

“...durante o tempo em que estive no Banco Mundial, pude ver com meus próprios olhos o efeito devastador que a globalização pode ter sobre países em desenvolvimento, em especial sobre as populações pobres desses países. Acredito que a globalização - a remoção de barreiras ao livre comércio e a maior integração das economias nacionais - pode ser uma força favorável, com potencial de enriquecer todas as pessoas do mundo, em especial as menos favorecidas. Entretanto, também acredito que, se for esse o caso, a maneira como a globalização tem sido gerenciada,...bem como as políticas que têm sido impostas aos paises em desenvolvimento no processo da globalização, precisa ser radicalmente repensada."

(Joseph E. Stiglitz) ${ }^{7}$

"O desejo de equilibrar o tribal e o universal sempre existiu. Agora, a democracia e a revolução nas telecomunicações (que dissemina a idéia da democracia e a torna premente) alçaram essa necessidade de equilíbrio entre o tribal e o universal a um patamar novo."

(John Naisbitt)

Ao abrir este item, apresenta-se algumas definições relacionadas aos termos "globalização" e "economia global", como subsídios para o texto que se segue:

- Economia Global (Global Economy) - "an economy with the capacity to work as a unit in real time on a planetary scale" (Castells, 1998);

- "Globalisation is a process in which geographic distance becomes less a factor in the establishment and sustenance of border crossing, long distance economic, political and sociocultural relations. People become aware of this fact. Networks of relations and dependencies therefore become potentially border

\footnotetext{
7 STIGLITZ, J.E. A globalização e seus malefícios: a promessa não-cumprida de benefícios globais. Tradução de Bazán Tecnologia e Lingüística. São Paulo: Futura, p. 10, 2001. Título original: Globalization and its discontents.

${ }^{8}$ NAISBITT, J. Paradoxo global. Tradução de Ivo Korytowski. Rio de Janeiro: Campus; São Paulo: Publifolha, p. 17, 1999. Título original: Global paradox.

${ }^{9}$ CASTELLS, M. The rise of the network society. Oxford: Blachwell Publishers, p. 92, 1998.
} 
crossing and worldwide. This potential internationalization of relations and dependencies causes fear, resistance, actions and reactions." (Guillén, 2001) ${ }^{10}$

Analisa-se, neste item, o pressuposto apresentado no capítulo 2: "o advento do mercado global insere no contexto da competitividade das empresas uma maior demanda por produtos e serviços de alta qualidade e intensivos em conhecimento e inovação; o mercado globalizado é característico da economia do conhecimento". Discute-se, portanto, o papel das empresas, das nações e das regiões no contexto da competitividade e o desenvolvimento e o impacto da inovação (ou dos sistemas de inovação) na prosperidade desses atores.

Apresenta-se, a seguir, a argumentação referente a esse pressuposto e sua relação com a pesquisa em curso baseando-se nos seguintes princípios e pensamentos de estudiosos do tema, a saber:

- O processo da globalização - o conceito nas últimas décadas; (Cassiolato \& Lastres, 1999)

- A globalização e as mudanças na competição: as características de uma nação que contribuem para que suas empresas criem e mantenham vantagem competitiva (Porter, 1989);

- A globalização diminui a importância dos estados-nações e faz ascender os estados-regiões? Discussões baseadas nas posições de Ohmae (1999);

- O paradoxo global: "quanto maior a economia mundial, mais poderosos são os seus protagonistas menores" (Naisbitt, 1999).

- O contraponto: os malefícios da globalização (Stiglitz, 2002)

\section{- O processo da globalizacão - o conceito nas últimas décadas:}

Cassiolato \& Lastres (1999) evocam a falta de consistência conceitual que envolve o termo "globalização" na conjuntura atual. Ao desenvolver o tema em seu livro, os autores apresentam uma discussão em torno da conjugação de fenômenos que levam à caracterização da globalização. Neste sentido, destacamse alguns aspectos que consistem em consenso entre estudiosos pesquisados

${ }^{10}$ GUILLÉN, M. The limits of convergence: globalization and organizational change in Argentina, South Korea and Spain. Princeton, NJ: Princeton University Press, 2001. Ambas as definições estão disponiveis na página da Internet da International Association of Science Parks (IASP): http://wnwwiaspws. 
pelos autores, quando se trata de aspectos relacionados ao processo de globalização. Os aspectos mencionados são apresentados na TAB. 3.3.

TABELA 3.3 - Aspectos de consenso que caracterizam o processo de globalização (Cassiolato \& Lastres, 1999) ${ }^{11}$

\begin{tabular}{l} 
Aspectos de consenso com relação \\
ao processo de globalização \\
\hline ...diante de um ambiente de \\
mudanças e incertezas, um grande \\
número de países respondeu aos \\
novos desafios com a adoção de \\
políticas de cunho liberal as quais \\
atribuem ao mercado a prerrogativa \\
de prover a auto-regulação \\
econômica."
\end{tabular}
de prover
econômica."

..."associado ao desenvolvimento do novo paradigma tecno-econômico, destaque-se a acelerada difusão das novas tecnologias de informação $e$ comunicação (TICs), que possibilitaram radical ruptura quanto à extensão dos contatos e de trocas de informações possiveis entre os atores, individuais e coletivos, mediante a diferenciação e ampliação de sistemas, canais, redes e organizações de geração, tratamento e difusão de informações."

Conclusão dos autores:

\section{Comentários relacionados}

Este comentário relaciona-se à diminuição de barreiras nacionais e regionais resultante de políticas macroeconômicas que prevaleceram na década de 80 em diversas regiões e países no mundo. As ações associadas a essas políticas envolviam desregulamentações e privatizações $e$, nos casos dos países em desenvolvimento, essas políticas visavam a atração de capital externo como solução para os problemas de competitividade das nações no mercado globalizado.

As tecnologias de informação e comunicação introduziram diversos avanços significativos facilitando o processamento, o armazenamento e transmissão de dados. Essas tecnologias permitiram o desenvolvimento de novos hábitos e processos comunicacionais que caracterizam, como dizem os autores, "...o que se convencionou denominar de "revolução informacional, e que caracterizou "...a conformação de uma nova era, para cuja caracterização concorrem diferentes designações: sociedade ou economia da informação ou do conhecimento; paradigma tecno-econômico das tecnologias da informação e comunicação, etc..."

Os autores consideram que a junção dos dois aspectos apresentados, a saber, o movimento de liberalização e desregulação dos mercados e o advento do paradigma das tecnologias de informação e comunicação, consistem no ..."elemento catalisador do processo de globalização nas últimas décadas."'”

Conseqüências do novo
paradigma:

- estabelecimento de uma nova dinâmica tecnológica e econômica, em nível internacional, onde 0 conhecimento "torna-se um ativo primordial de competição, ao mesmo tempo em que vêm-se impondo novas formas de organização e interação entre as empresas $e$ entre estas e outras instituições...e favorecendo rápidas mudanças nas estruturas de pesquisa, produção e comercialização."

- Os autores adicionam que o processo de

\footnotetext{
${ }^{11}$ A composição desta tabela foi feita a partir de uma seleção de aspectos relativos à globalização abordados por Cassiolato \& Lastres (1999), em seu livro, às páginas 39 a 51.
} 


\begin{tabular}{|c|c|}
\hline $\begin{array}{l}\text { Aspectos de consenso com relação } \\
\text { ao processo de globalização }\end{array}$ & Comentários relacionados \\
\hline & $\begin{array}{l}\text { globalização envolve também } \begin{array}{c}\text { mudanças } \\
\text { políticas, comerciais, financeiras, culturais e }\end{array} \\
\text { sociais que vêm delineando uma nova forma de } \\
\text { organização espacial econômica, caracterizada } \\
\text { principalmente pela concentração da atividade } \\
\text { produtiva (e dos fluxos de comércio, informação e } \\
\text { conhecimento) na Triade (EUA, Japão e países } \\
\text { da Europa Ocidental) - blocos econômicos } \\
\text { hegemônicos. } \\
\text {-...a globalização principalmente daquelas } \\
\text { atividades mais estratégicas, além de concentrar- } \\
\text { se nos paises da Triade...é vista como } \\
\text { provocando um processo de polarização } \\
\text { crescente entre blocos, países, regiões e grupos } \\
\text { sociais. }\end{array}$ \\
\hline
\end{tabular}

- A globalização e as mudanças na competição: as características de uma nação que contribuem para que suas empresas criem e mantenham vantagem competitiva

Como foi visto no item anterior, um dos principais ativos para a competitividade das empresas é o conhecimento, associado a estratégias de pesquisa, produção e comercialização em nível global. Porter (1989), em seu livro "A Vantagem Competitiva das Nações", aborda um interessante aspecto com relação ao sucesso internacional de determinadas empresas, levantando um paradoxo: embora haja uma natural indução no sentido de que a internacionalização das empresas, no processo global, leve a uma diminuição da importância das nações, o autor, em suas pesquisas, contradiz essa tendência, mostrando que "A vantagem competitiva é criada e mantida através de um processo altamente localizado".

"O papel do país sede parece ser tão forte quanto sempre foi mais ainda. Embora a globalização da competição possa, aparentemente, tornar a nação menos importante, em lugar disso parece fazê-la mais importante. Com menos impedimentos ao comércio para proteger as empresas e indústrias internas não-competitivas, a nação sede adquire significação crescente, porque é fonte do conhecimento e da tecnologia que sustenta a vantagem competitiva." (Porter, 1989)

Ao estabelecer uma teoria para compreender a vantagem competitiva das nações, Porter (1989) criou a figura de um "diamante". Nesta figura são representados os determinantes, a saber, os atributos que caracterizam o ambiente de competição das empresas, como um sistema, e que promovem ou 
criam barreiras à vantagem competitiva. Sendo um sistema, o "diamante" é "mutuamente fortalecedor", os países teriam maior probabilidade de êxito competitivo nos segmentos de empresas onde o "diamante" do país é o mais favorável. Isto significa dizer que os países alcançam êxito não por meio de ações isoladas de empresas, mas sim por grupos ou segmentos de empresas (indústrias) que atuam como um sistema. Na FIG. 3.2, apresenta-se o "diamante" de Porter, contendo os determinantes da vantagem nacional.

Analisando a economia de uma nação, segundo Porter, "a economia de um país contém uma mistura de grupos, cuja constituição e fontes de vantagem (desvantagem) competitiva refletem o estado do desenvolvimento da economia".

$O$ desenvolvimento competitivo das economias das nações, segundo Porter (1989) apresenta quatro etapas que o impulsionam. Na FIG. 3.3 são apresentadas essas etapas.

No interesse desta pesquisa, qual seja analisar o pressuposto apresentado, explora-se a etapa da economia impulsionada pela inovação. $O$ autor usa o modelo do "diamante" para ilustrar os determinantes da vantagem nacional e suas interações na etapa da inovação. Na FIG. 3.4, encontra-se a representação gráfica do "diamante" relacionado à economia impulsionada pela inovação.

A partir do exposto na FIG. 3.4, pode-se conduzir ao pensamento de que na economia impulsionada pela inovação é possivel observar-se um maior número de grupos ou segmentos de empresas capazes de competir, tendo em vista uma conjunção de determinantes, a saber:

- Condições de demanda - há uma crescente sofisticação da demanda, tanto por parte do consumidor, que se torna mais exigente de comodidades e acirra a rivalidade interna, bem como por parte do surgimento de clientes-empresários mais sofisticados; ${ }^{12}$

- Condições de fatores - no caso da etapa de inovação, são criados fatores de produção avançados e as desvantagens seletivas de fatores provocam a busca pela inovação; neste contexto, é

\footnotetext{
12 Segundo Porter (1989), este aparecimento de clientes-empresários mais sofisticados gera uma animação interna favorável que provoca uma constante busca por inovação, fazendo com que surjam indústrias de apoio de classe mundial.
} 
importante ressaltar que, em decorrência, as instituições de ensino e pesquisa bem como a infra-estrutura de desenvolvimento tecnológico tendem a se sofisticar;

- Estratégias, estrutura e rivalidade das empresas - na economia impulsionada pela inovação, as empresas estabelecem estratégias globais de atuação nos mercados;

- Indústrias correlatas e de apoio - o país conta com indústrias abastecedoras e correlatas e estas são bem desenvolvidas.

As condiçōes que, no país, govemam a maneira pela qual as empresas são criadas, organizadas e dirigidas, mais a natureza da rivalidade intema.

A posiçăo do país nos fatores de produção, como trabalho especializado ou infraestrutura, necessários à competição em determinado segmento.

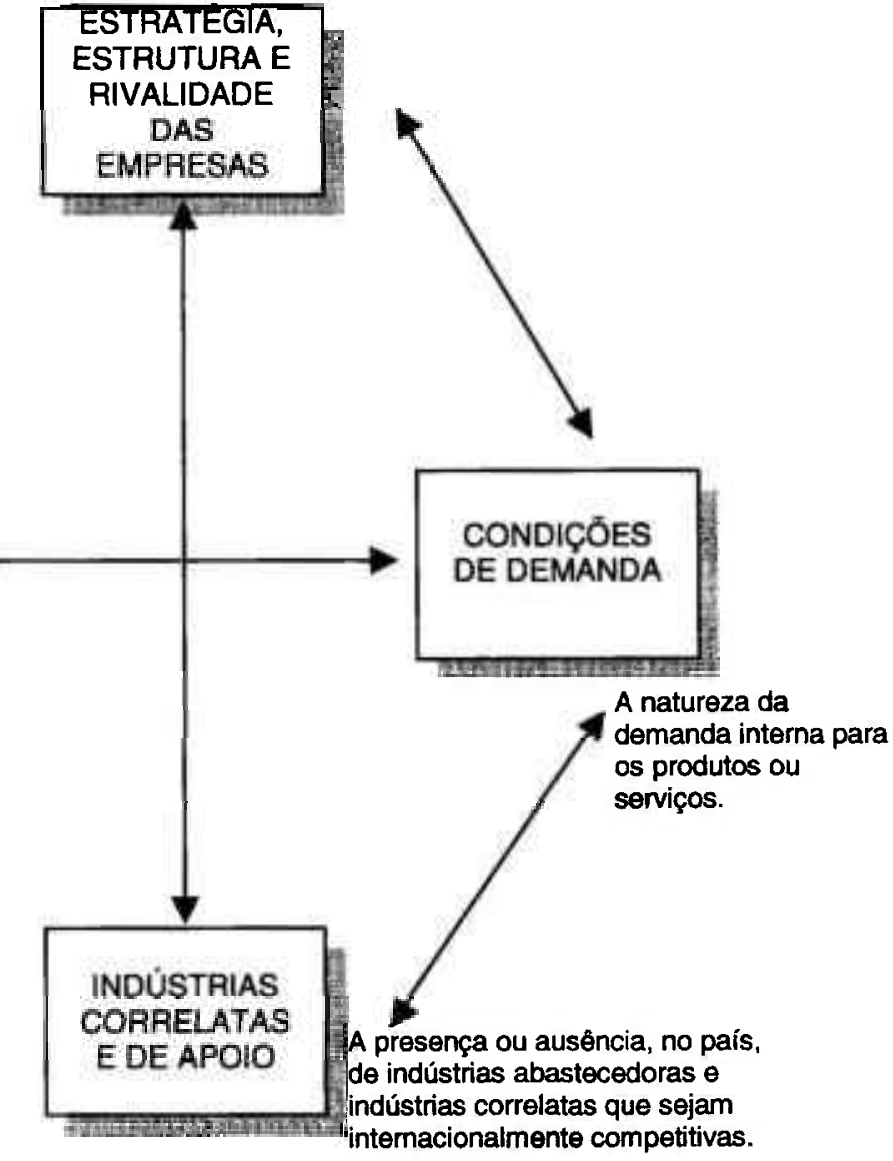

FIGURA 3.2: O "diamante" de Porter (1989, p. 88) - determinantes da vantagem nacional (a título de esclarecimento, foram inseridas as definições dos determinantes, que não constam na figura original do autor). 


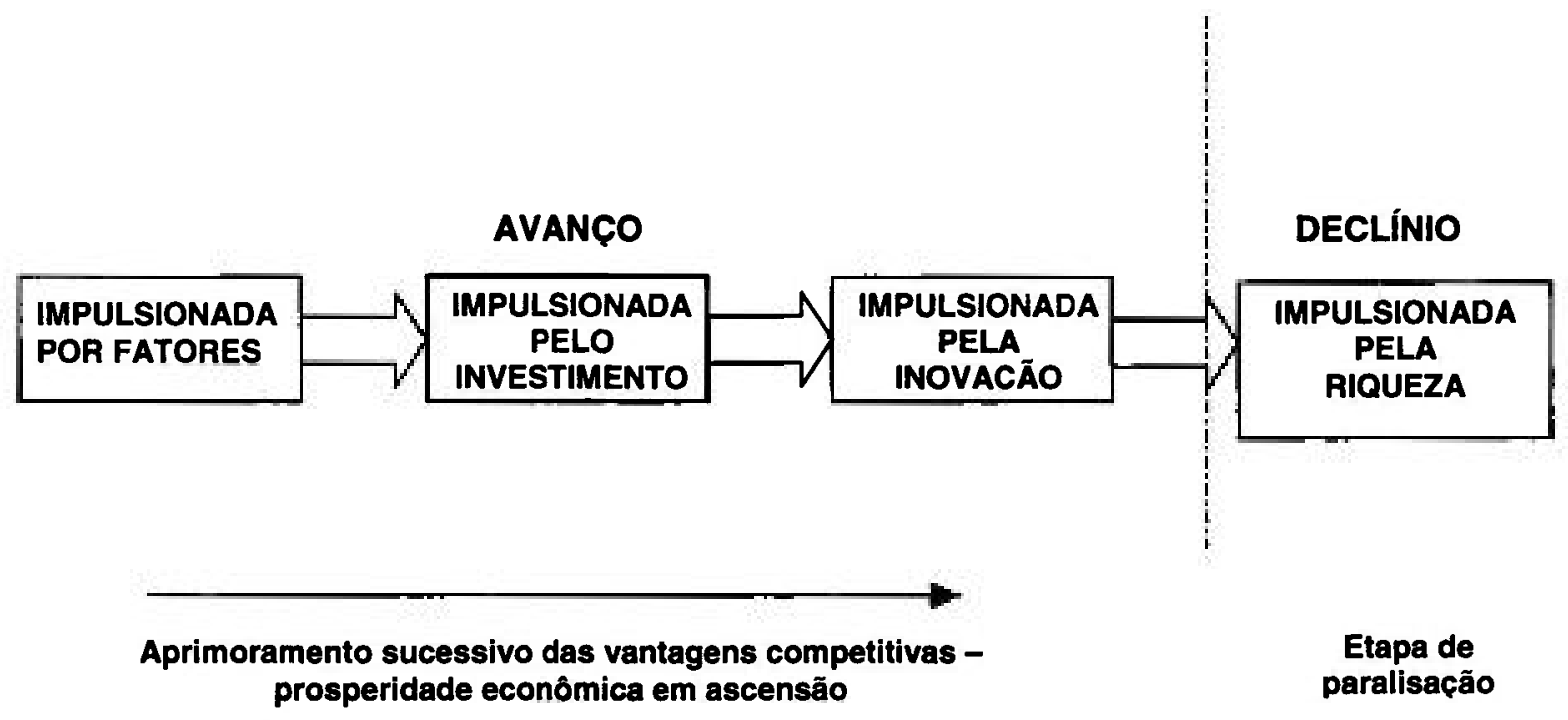

FIGURA 3.3: Quatro etapas do desenvolvimento competitivo nacional (Porter, 1989 , p.614) (a parte inferior da figura não consta do desenho original do autor; ela foi acrescida com 0 intuito de esclarecer 0 envolvimento das etapas apresentadas com o crescimento do país).

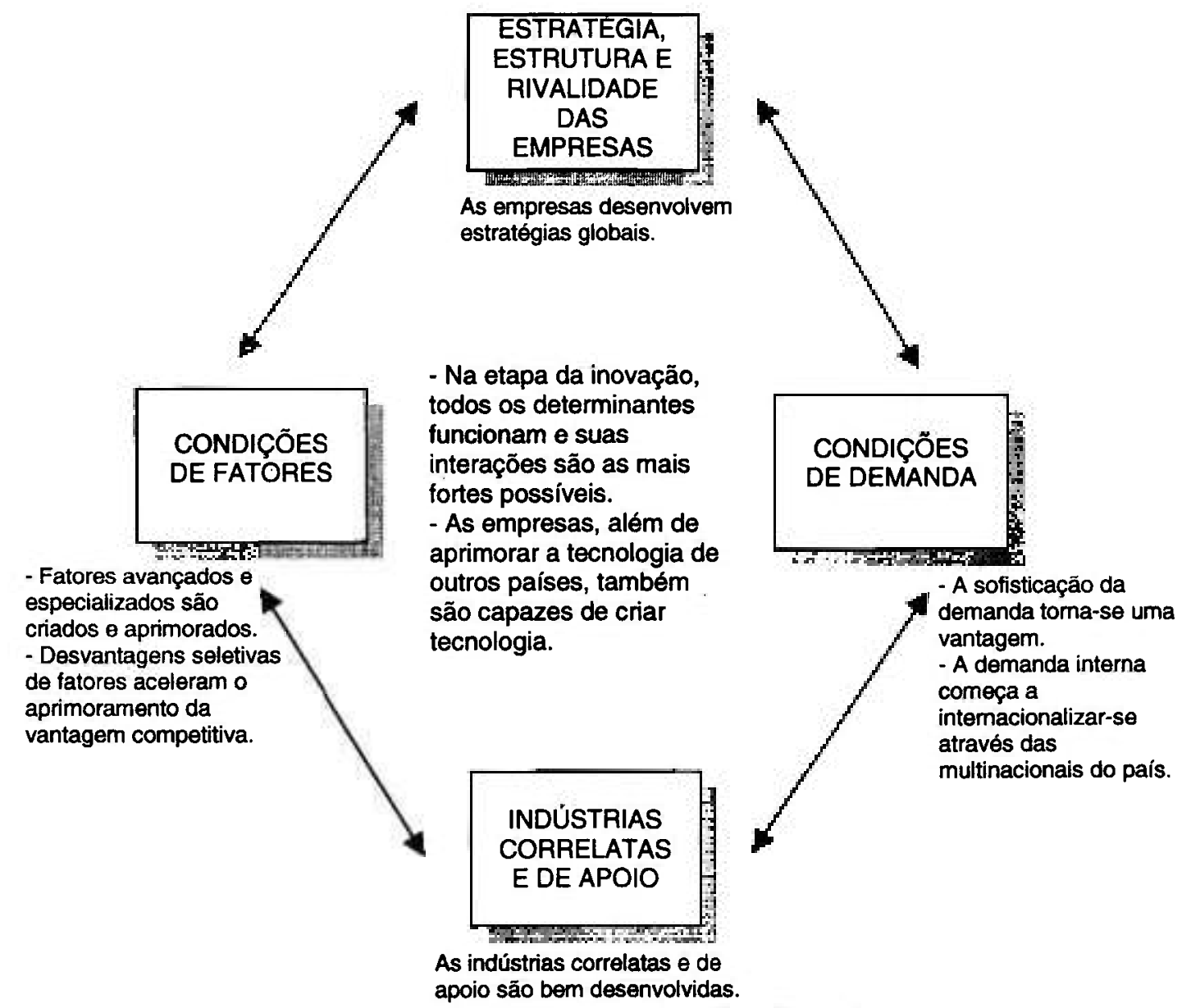

FIGURA 3.4: Economia impulsionada pela inovação (no desenho original, os quadros são totalmente escuros, para demonstrar que todos os determinantes funcionam; aqui optou-se por escrever esta informação no centro da figura). Porter (1989, p. 622). 
Conclui-se que a economia impulsionada pela inovação apresenta vantagens sob o ponto de vista de prosperidade econômica.

Destaca-se também o papel do governo e suas estratégias e ações na economia impulsionada pela inovação. Neste contexto há uma nova filosofia de intervenção do estado:

"A alocação de capital, proteção, controles de licenciamento, subsídios de exportação e outras formas de intervenção direta perdem relevância ou efetividade na competição baseada na inovação. $O$ ímpeto de inovar, as habilitações para fazê-lo e os sinais que guiam as direções de inovação devem vir, em grande parte, do setor privado. Quando a economia se amplia e aprofunda, o governo não pode pretender acompanhar todas as indústrias existentes e novas e todas as ligaçōes entre elas...Em lugar disso, os esforços governamentais são melhor dirigidos para as formas indiretas, como estímulo à criação de fatores cada vez mais adiantados, melhoria da qualidade de demanda interna, estímulo à formação de novos negócios, preservação da rivalidade interna ..." (Porter, 1989)

- A globalização diminui a importância dos estados-nacões e faz ascender os estados-regiões? Argumentos baseados nas posições de Ohmae (1999)

Foi apresentada, no item anterior, a visão de Porter, que conduz à importância dos sistemas nacionais, dos estados-nações, para a prosperidade e a competitividade. Observa-se nesta etapa a contraposição dos estados-regiões aos estados-nações no mundo globalizado.

Neste sentido, um dos estudiosos dessa teoria é Ohmae (1999) que, em seu livro "O Fim do Estado-Nação", trata do enfraquecimento dos estadosnações em sua capacidade de priorizar a lógica global nas suas políticas e estratégias, com suas possibilidades e impactos relacionados ao mercado globalizado. $O$ autor apresenta a contraposição aos estados-nações, introduzindo as regiōes que ultrapassam as fronteiras territoriais e estruturam zonas econômicas naturalmente formadas a partir de aproximações comerciais e culturais. Os estados-regiões consistem em unidades econômicas (na maioria das vezes com características culturais convergentes) cujo foco não é local e, portanto, são regiões que recebem de forma confortável (ou mesmo estimulam) o capital e produtos estrangeiros (essas regiōes podem, inclusive, estar localizadas dentro de um estado-nação).

"...eles acolhem favoravelmente tudo que contribuir para empregar produtivamente sua população, para melhorar sua qualidade de vida e para dar-lhe acesso aos melhores e mais baratos produtos de 
qualquer parte do mundo...Os Estados-regiões também aproveitam os excedentes gerados por essas atividades para elevar ainda mais a qualidade de vida de seu provo, e não para financiar o mínimo público ou para subsidiar indústrias obsoletas." (Ohmae, 1999, p.83)

Ohmae não defende um posicionamento contrário aos estados-nações (no que tange aos governos centrais); o autor ressalta as grandes oportunidades criadas por essas regiões quando as mesmas são tratadas como "portōes de entrada" para a economia global e, portanto, podem trazer benefícios para as nações e suas populações. Transcreve-se abaixo um pequeno trecho do autor onde ele fala sobre a prosperidade regional, citando como um dos exemplos de futuro o Estado de São Paulo.

"Onde existe a prosperidade, sua base é regional. E quando uma região prospera, sua boa fortuna espalha-se pelos territórios adjacentes dentro e fora da federação política a que pertence. O progresso econômico dentro e ao redor de Bangcoc, por exemplo, levou os investidores a explorar opções em outros pontos da Tailândia... 0 mesmo poder-se-ia dizer de São Paulo - se o governo central brasileiro aprender a tratá-la como um genuíno Estado-regiāo e permitir que se integre à economia global. Caso o faça, ao menos uma região no Brasil poderia aderir à OECD dentro de cerca de dez anos. Caso não o faça - devido a preocupações com o mínimo público ou ao medo de que o equilibrio entre as regióes seja sacrificado - o país como um todo poderá até sair da lista das economias recém-industrializadas." (Ohmae, 1999, p. 95)

Apresenta-se, na TAB. 3.4, alguns "Estados-regiões" apontados por

Ohmae.

TABELA 3.4 - O advento dos "Estados-regiões" 13

\begin{tabular}{l|l}
\hline \multicolumn{1}{c|}{$\begin{array}{c}\text { Uniōes Regionais já } \\
\text { Estabelecidas }\end{array}$} & \multicolumn{1}{c}{ Uniões Regionais Emergentes } \\
\hline Norte da Itália & $\begin{array}{l}\text { Zona Econômica Integrada do Nordeste da Ásia: } \\
\text { integra o delta do Tumen com o projeto do nordeste da } \\
\text { Ásia. Pretende criar uma Zona Econômica Especial } \\
\text { com raio de 150 km com Vladivostok no centro e } \\
\text { Nakhodka, estabelecendo um importante vínculo entre } \\
\text { a Ásia e a Europa por meio da ferrovia transiberiana. }\end{array}$ \\
\hline $\begin{array}{l}\text { Baden-Würtemberg (alto do } \\
\text { Reno) }\end{array}$ & $\begin{array}{l}\text { Projeto Delta do Tumen: cria um complexo comercial } \\
\text { e de transporte de US\$ 30 bilhões estendendo-se por } \\
\text { Rajin (Coréia do Norte), Hunchun (China) e Posyet } \\
\text { (Rússia). }\end{array}$ \\
\hline País de Gales & Coréia do Norte e do Sul \\
\hline San Diego/Tijuana & $\begin{array}{l}\text { República da China Meridional Província de } \\
\text { Guangdong, Província de Fujian e Hong-Kongl } \\
\text { Taiwan (esta região engloba uma populacão de cerca }\end{array}$ \\
\hline
\end{tabular}

\footnotetext{
${ }^{13} \mathrm{~A}$ composição desta tabela foi feita a partir de uma seleção de aspectos relativos aos Estadosregiōes abordados por Ohmae (1999), em seu livro, às páginas 73 a 95 .
} 


\begin{tabular}{|c|c|}
\hline $\begin{array}{l}\text { Uniōes Regionais já } \\
\text { Estabelecidas }\end{array}$ & Uniōes Regionais Emergentes \\
\hline & $\begin{array}{l}\text { de } 120 \text { milhões de pessoas e um Produto Interno Bruto } \\
\text { combinado de US } \$ 310 \text { bilhões. }\end{array}$ \\
\hline $\begin{array}{l}\text { Osaka e a região de Kansai } \\
\text { (Japão) }\end{array}$ & $\begin{array}{l}\text { Hong-Kong e Shenzhen (China): foi a primeira Zona } \\
\text { Econômica Especial estabelecida na China. O projeto } \\
\text { do Centro Tecnológico e Científico da China pretende } \\
\text { que a região se torne o Vale do Silicio chinês. }\end{array}$ \\
\hline $\begin{array}{l}\text { Vale do Silício/Bay Área de San } \\
\text { Francisco na Califórnia }\end{array}$ & Yunnan (China)-Laos-Vietnã \\
\hline $\begin{array}{l}\text { Pusan (extremidade sul da } \\
\text { península da Coréia) e as } \\
\text { cidades de Fukuoka e } \\
\text { Kitakyushu (no norte da ilha } \\
\text { japonesa de Kyushu) }\end{array}$ & $\begin{array}{l}\text { "Sepzone" - a cidade de Ho Chi Minh estará atraindo } \\
\text { capital estrangeiro como uma zona de processamento } \\
\text { de exportações. }\end{array}$ \\
\hline $\begin{array}{l}\text { Tóquio e regiões adjacentes } \\
\text { (Japão) }\end{array}$ & $\begin{array}{l}\text { Triângulo de Maior Crescimento (estreito de } \\
\text { Malaca): conecta Penang, Medan (Sumatra) e Phuket } \\
\text { (Tailândia) }\end{array}$ \\
\hline $\begin{array}{l}\text { Triângulo da Pesquisa: Carolina } \\
\text { do Norte (EUA) }\end{array}$ & $\begin{array}{l}\text { Triângulo do Crescimento: Cingapura, Johor } \\
\text { (Malásia)e as ilhas Riau (Indonésia). }\end{array}$ \\
\hline $\begin{array}{l}\text { A região francesa de Rhône-Alps } \\
\text { (Lyon, com estreitos vínculos } \\
\text { com a ltália) }\end{array}$ & \\
\hline $\begin{array}{l}\text { Laguedoc-Roussilon (Toulouse, } \\
\text { com estreitos vínculos com a } \\
\text { Catalunha, na Espanha) }\end{array}$ & . \\
\hline
\end{tabular}

Conclusões na visão de Ohmae:

- "Os Estados-regiōes acolhem favoravelmente o investimento estrangeiro. Eles acolhem favoravelmente a propriedade estrangeira. Eles acolhem favoravelmente os produtos estrangeiros".

- "Os Estados-regiões são portões de entrada à economia global tão eficazes porque suas características definidoras são moldadas pelas exigências dessa economia."

- "Os Estados-regiões têm que ser suficientemente pequenos para seus cidadãos compartilharem de interesses como consumidores, mas de tamanho suficiente para justificar economias não de escala,... mas de serviços ...essenciais à participação na economia global."

- ...por estarem voltados para a economia global, e não para suas nações hospedeiras, os Estados-regiões ajudam a criar um espírito internacionalista que neutraliza muitos dos tipos comuns de tensão social."

- "A essência do desafio... não é resolver todos os problemas em nivel local, mas possibilitar sua solução aproveitando os recursos globais. A eficácia dos Estados-regiōes depende de sua capacidade de explorar soluções globais." 
- O paradoxo global: "quanto maior a economia mundial, mais poderosos são os seus protagonistas menores" (Naisbitt, 1999)

No item anterior, foi abordado o tema da formação de uniões regionais como forma de atuar em dimensão global. Neste item, aborda-se um interessante aspecto que está muito ligado ao tema desta pesquisa, a saber, o espírito empreendedor.

Para desenvolver o tema na economia global, buscou-se o tratamento dado por Naisbitt (1999) quando coloca o paradoxo citado no início deste item.

O panorama mundial aponta para o declínio dos Estados-nações, para a formação de uniões regionais (alianças econômicas), para a economia baseada num mercado global, para a revolução nas comunicações, para a disseminação dos sistemas democráticos, para a fragmentação das grandes empresas em confederações de pequenas empresas e empreendedores. Como diz Naisbitt (1999):

"Quanto mais universais nos tornamos, mais tribalmente agimos, o que, no paradoxo global, também significa partes menores e em maior número."

"Com a nova ênfase no tribal em um mundo cada vez mais global, o mantra da Nova Era "pense globalmente, aja localmente" vira de ponta-cabeça. Ele é agora: "Pense localmente, aja globalmente." (Naisbitt, 1999, p.18)

O comentário do autor reforça sua teoria de que quanto mais cresce a economia global, mais significativa é a atuação dos atores menores; os grandes atores da economia global estão ficando menores e mais compactos. $\mathrm{E}$, neste ponto, entra em questão a figura do empreendedor. Ou seja, as grandes empresas, para enfrentarem a nova era, como aborda Naisbitt, estão se fragmentando em novas formas e alianças, entre elas estão as confederações de pequenas empresas e empreendedores. As tendências apontam para uma capacidade cada vez maior de empresas de pequeno e médio porte (atuando em redes e confederações) de competir no mercado, por serem mais inovadoras e ágeis do que as grandes empresas.

A cooperação, as alianças estratégicas, a atuação em redes, facilitadas pela revolução nas telecomunicações e nos sistemas de informações, são as soluções encontradas pelas empresas que, ao invés de buscarem estratégias de crescimento, procuram tornar-se redes de unidades de negócios de menor porte, que possam suplantar as dificuldades e barreiras burocráticas. 
"A metáfora quase perfeita à transição de toda sorte de burocracia para unidades pequenas e autônomas é a mudança do "mainframe" para os computadores pessoais interligados em redes." (Naisbitt, 2002)

Sob os pontos de vista cultural e político, o retorno ao tribalismo pode ser observado, no mundo, por meio dos seguintes aspectos:

- os idiomas das minorias estão retomando sua importância no contexto da herança dos povos;

- os governos centrais, como estruturas governamentais importantes, estão sendo gradualmente transformados; a estrutura do poder está sendo modificada: “do dilema esquerda contra direita para o dilema local versus global ou universal versus tribal'(Naisbitt, 2002).

\section{- O contraponto: os malefícios da globalizacão (Stiglitz, 2002)}

Stiglitz, Prêmio Nobel de Economia de 2001, em seu livro "A globalização e seus malefícios", faz uma análise das expectativas não cumpridas, dos benefícios da globalização, bem como levanta as necessidades de mudanças nas instituições econômicas internacionais, de forma a auxiliar a busca por uma estabilidade econômica global. O pensamento de Stiglitz (2002) é usado nesta pesquisa como o contraponto na análise do processo de globalização. Este contraponto é estruturado a partir dos aspectos negativos da globalização e seus impactos na sociedade e economias globais.

Segundo Stiglitz (2002), ao lado de diversos benefícios observados com a globalização (como, por exemplo, o sucesso da Ásia Oriental baseado nas novas oportunidades de comércio e no acesso a mercados e ao conhecimento), muitos problemas decorrem desse processo, principalmente em nações do mundo em desenvolvimento, afetadas pelas regras impostas por instituições econômico-financeiras internacionais, tais como o Fundo Monetário Internacional, - Banco Mundial e a Organização Mundial do Comércio.

Existem diversos aspectos que devem ser observados quando da discussão de soluções para os problemas gerados pela globalização. Em primeiro lugar, conforme Stiglitz, é preciso entender que a maior parte dos problemas está relacionada à forma como vem sendo gerido o processo de globalização e, neste caso, aponta-se para uma necessária reforma nas instituições econômico- 
financeiras internacionais que são responsáveis pelos impactos do processo de globalização.

No entanto, as posições radicais muitas vezes extemadas por ativistas em reuniões dessas instituições, não têm apresentado contribuições para a solução dos problemas. É preciso considerar que o processo de globalização tem trazido benefícios para regiões e populações (maior ação da sociedade civil, em busca de democracia e justiça social, reformas sociais em diversas nações, entre outros). Portanto, que caminhos precisam ser trilhados para buscar soluções para os impactos negativos da globalização? Stiglitz (2002) propõe uma estratégia de reforma "multidirecionada": em arranjos econômicos internacionais, de "mentalidades" nas nações desenvolvidas e nas instituições econômicofinanceiras internacionais, de forma a que estas venham a refletir, em suas políticas, ações de real interesse "global", que beneficiem o meio ambiente, que considerem as posições dos pobres, que promovam a democracia e regras mais justas de comércio internacional; governos mais eficazes nos países em desenvolvimento ("com judiciários fortes $e$ independentes, responsabilização democrática, abertura e transparência, bem como fim da corrupção que vem sufocando a eficácia do setor público e o crescimento do setor privado" (Stiglitz, 2002)).

Finalizando este item, observa-se que a argumentação enfocada com relação ao pressuposto apresentado no capítulo 2 , referente ao advento dos mercados globalizados e suas conseqüências nas empresas, nas nações e nas regiões, aponta para as seguintes reflexões:

- Dois aspectos são considerados como catalisadores do processo de globalização, a saber: os movimentos de liberalização e desregulamentação dos mercados, e os novos paradigmas decorrentes da revolução nas tecnologias de informação e comunicação;

- Neste cenário global estabelecido com os novos movimentos econômicos e tecnológicos, o conhecimento torna-se um importante ativo para a competitividade das empresas e das organizações; bem como, em decorrência deste fato, novos arranjos entre empresas, novos tipos de organizações e de redes de organizações e instituições estão surgindo; 
- As nações, neste contexto, e seus governos, devem estruturar estratégias e ações em apoio ao desenvolvimento de uma economia impulsionada pela inovação; os governos devem apresentar um novo estilo de intervenção do estado na vida da nação: ao invés de estratégias diretas de proteção, de alocação de capital, de controles e subsídios, devem desenvolver ações indiretas, tais como estímulos à inovação nas empresas, à melhoria e à diversificação da demanda interna, à formação de novos e melhores negócios, à maior participação da iniciativa privada nos programas de desenvolvimento, entre outras;

- O advento dos estados-regiões ou das uniões regionais representa estratégias com resultados positivos, capazes de fortalecer as regiões na lógica global; essas estruturas transcendem barreiras territoriais e se estruturam com base em zonas econômicas formadas por aproximações e interesses comerciais e culturais; elas podem ser formadas, até mesmo, dentro de nações, integrando regiões à economia global; estas regiões, por sua vez, podem constituir-se em atração de prosperidade para outras regiões adjacentes;

- Novas estratégias empresariais estão sendo observadas na economia global; as grandes empresas estão se fragmentando em busca de um posicionamento mais ágil e inovador para se tornarem mais competitivas; novas oportunidades estão surgindo para os atores menores, entre eles os pequenos e médios empreendedores; observa-se a formação de diferentes tipos de alianças e confederações de pequenas empresas e empreendedores; as grandes empresas buscam estratégias de atuação em redes de unidades de negócios de menor porte;

- No contraponto, o processo de globalização agrava problemas existentes nos países e regiões menos desenvolvidas do planeta; a maior parte dos problemas são ocasionados por políticas impostas pelas instituições econômico-financeiras internacionais que, por sua vez, são fortemente influenciadas por nações desenvolvidas e seus interesses diretos; são necessárias reformas na gestão 
dessas instituições bem como em sua governança, de maneira que possa existir uma maior participação dos países em desenvolvimento, buscando-se o estabelecimento de ações que venham a disseminar os benefícios do processo de globalização e amainar os seus malefícios.

\subsection{Os parques científicos e tecnológicos}

"Science parks and incubators have had varying effects on local and regional economic development around the world. Some have been extremely robust and others have had average to little success. The original "raisons d'etre" for the science park phenomenon that began in the 1950s, especially those related to universities and research institutes, were to foster enterprise development by creating a special environment for innovation to occur and to optimize the value of land assets."

(Frank J. Giunta) $^{14}$

Neste item apresenta-se uma visão geral do movimento de parques científicos e tecnológicos, no interesse desta pesquisa. A organização da revisão deste fenômeno está assim estruturada:

- Item 3.3.1: apresentação das definições e terminologias referentes ao tema, bem como algumas formas de classificação; a situação dos Parques Tecnológicos no Brasil;

- Item 3.3.2: apresentação das principais organizações internacionais que agrupam e formam redes de parques científicos e tecnológicos (muitas delas aglutinando também as incubadoras de empresas), os principais indicadores mundiais relativos ao movimento;

- Item 3.3.3: uma breve discussão da situação atual de uma experiência importante que é considerada como início do movimento de parques científicos e tecnológicos: o Vale do Silício (Califómia - Universidade de Stanford). Não se pretende, portanto, realizar uma revisão dos aspectos históricos desta experiência, uma vez que esses já foram bastante explorados anteriormente. $O$ objetivo desta abordagem é trazer alguns aspectos estratégicos, de adaptação às mudanças globais e

${ }^{14}$ GIUNTA, F.J. The emerging paradigm of new urbanism in science park development. In: $\mathrm{V}$ WORLD CONFERENCE ON SCIENCE PARKS. October 29-31, 1996, Rio de Janeiro. Proceedings... Rio de Janeiro: AURRP/IASP/ANPROTEC, 1996, p. 17. 
locais, que impactaram essas experiências. A abordagem será realizada com base em estudos desenvolvidos por Saxenian (1996) e Murphy (1997);

- Item 3.3.4: Breve discussão de aspectos positivos e negativos do movimento de parques científicos e tecnológicos.

\subsection{1: Apresentação de definições e terminologias}

$\mathrm{Na}$ busca por experiências internacionais que possam contribuir para este estudo, inferiu-se que a implantação de Parques de Ciência e Tecnologia, e de mecanismos similares, iniciou-se nas décadas de 1960 e 1970, tendo como países pioneiros os Estados Unidos e a Inglaterra.

Como será abordado no item 3.3.3, este movimento tem suas origens na Universidade de Stanford (Califórnia - Estados Unidos), culminando na experiência conhecida como o "Vale do Silicio". Esta experiência influenciou uma série de modelos mundiais de criação de espaços que privilegiassem e estimulassem 0 desenvolvimento da relação entre a atividade acadêmica das universidades (centros de pesquisa) e a iniciativa privada, com vistas a gerar negócios inovadores, a criar oportunidades para evitar a evasão de cérebros da região, a apoiar o desenvolvimento regional, entre outras ações de caráter econômico e imobiliário.

Dada a necessidade imperativa de se fazer um maior uso dos artefatos científicos e tecnológicos - ou das chamadas infra-estruturas científicotecnológicas - como fatores promotores do desenvolvimento econômico principalmente face à crescente competitividade econômica, conforme abordado em itens anteriores neste capítulo, esse movimento tem se espalhado mundialmente, detectando-se um grande desenvolvimento na década de 1990, principalmente entre as chamadas economias em desenvolvimento ou emergentes. Assim, a experiência internacional, no que se refere ao planejamento, implantação e operacionalização de Parques de Ciência e Tecnologia, consiste em aspecto essencial ao presente estudo no sentido de prover informações diversificadas sobre os diferentes modelos adotados, sobre os aspectos que nortearam tais opções, seus principais atores, bem como os principais estímulos e obstáculos enfrentados na sua execução.

Discussões têm sido realizadas com relação às terminologias utilizadas pelas iniciativas internacionais bem sucedidas. De acordo com 
Torkomian (1996), os termos Science Park e Research Park são geralmente utilizados em países anglo-saxões, encontrando-se, ainda outras terminologias tais como Tecnópole (França, Japão e Itália), Casas de Inovação (Suécia), Centros de Inovação (Alemanha), porém deve-se considerar que, na visão da presente pesquisa, essas terminologias encerram diferentes objetivos.

É importante mencionar as diferenças entre as definições para Science Park e para Parque Tecnológico, demonstradas por Bolton (1997), quando se refere às visões da UK Science Parks Association e do European Union's SPRINT Programme:

- Science Parks (Parques Científicos) - normalmente tem ligações formais e operacionais com instituições de ensino superior ou com centros de pesquisa; é projetado para encorajar a formação e o crescimento de empresas baseadas em conhecimento e outras organizações normalmente residentes no local; tem uma gerência que está ativamente engajada na transferência de tecnologia e práticas de negócios em apoio às organizações residentes;

- Parques Tecnológicos - são desenvolvidos com o objetivo de acomodar empresas engajadas na aplicação comercial de alta tecnologia, com atividades que incluem P\&D, produção e vendas. Distingue-se da concepção de Science Parks devido à sua grande ênfase na produção, sendo o envolvimento acadêmico não essencial.

Fazendo um paralelo com os aspectos que estão sendo abordados para o desenvolvimento do modelo alvo desta pesquisa, pode-se considerar que o modelo a ser desenvolvido deverá ser híbrido, pois, neste caso, o envolvimento acadêmico é fator de grande importância para o desenvolvimento dos objetivos estratégicos da proposta desta pesquisa.

Outro aspecto importante destacado por Bolton (1997) em seu texto está relacionado às características estruturais e estratégicas dos Parques Científicos ou Tecnológicos. Para isto, ele classifica os parques em "estáticos" ou "dinâmicos". São as seguintes as características apresentadas para cada uma das classificações:

- Estático - é similar a um estado industrial, porém com prédios e instalações bem estruturadas e projetadas e buscam como arrendatários empresas baseadas em conhecimento; 
a Dinâmico - é projetado dentro de um conceito desenvolvimentista de crescimento do negócio. Ele tem por objetivo criar massa crítica de indústrias baseadas no conhecimento que se instalam na região, ou, pelo menos, formam um cluster. Também objetiva manter uma ligação com os centros locais de ensino superior e de pesquisas, de forma a ativar as ações de disseminação e gestão do conhecimento.

Como definições mais comumente adotadas, apresenta-se, na TAB. 3.5, aquelas veiculadas por associações internacionais do setor, bem como a visão da ANPROTEC - Associação Nacional de Entidades Promotoras de Empreendimentos de Tecnologias Avançadas (2002), apresentada em seu "Glossário Dinâmico de Termos na Área de Tecnópolis, Parques Tecnológicos e Incubadoras de Empresas", lançado em setembro de 2002.

TABELA 3.5 - Principais definições adotadas para Parques Científicos e Tecnológicos

\begin{tabular}{l|c}
\hline Fonte & \multicolumn{1}{c}{ Definição } \\
\hline ANPROTEC & $\begin{array}{c}\text { (a) Complexo industrial de base científico-tecnológica } \\
\text { planejado, de caráter formal, concentrado e cooperativo, } \\
\text { que agrega empresas cuja produção se baseia em } \\
\text { pesquisa tecnológica desenvolvida em centros de P\&D } \\
\text { vinculados ao Parque; } \\
\text { (b) Empreendimento promotor da cultura da inovação, da } \\
\text { competitividade, do aumento da capacitação empresarial } \\
\text { fundamentado na transferência de conhecimento e } \\
\text { tecnologia, com o objetivo de incrementar a produção de } \\
\text { riqueza. }\end{array}$ \\
\hline IASP ${ }^{15}$ & $\begin{array}{l}\text { Um Parque Cientifico é uma organização gerida por profissionais } \\
\text { especializados, cujo objetivo fundamental é incrementar a } \\
\text { riqueza de sua comunidade promovendo a cultura da inovação e } \\
\text { da competitividade das empresas e instituições geradoras de } \\
\text { conhecimento instaladas no parque ou associadas a ele. } \\
\text { Com este objetivo, um Parque Científico estimula e gere o fluxo } \\
\text { de conhecimento e tecnologia entre universidades, instituições } \\
\text { de pesquisa, empresas e mercados; promove a criação e o } \\
\text { crescimento de empresas inovadoras mediante mecanismos de } \\
\text { incubação e de "spin-off", e proporciona outros serviços de valor } \\
\text { agregado assim como espaço e instalações de alta qualidade. }\end{array}$ \\
\hline
\end{tabular}

15 IASP - International Association of Science Parks. Disponivel em: http://www.iasp.ws/; acesso em 15/03/2003.

${ }^{16}$ Em sua definição, a IASP considera a expressão "Parque Científico" também para "Parque Tecnológico" ou "Tecnópolis", embora reconheça que podem existir diferenças entre projetos definidos com essas expressões. As definições, nesta tabela, são apresentada em português, por meio de tradução livre do texto original (em inglês), de responsabilidade desta autora. 


\begin{tabular}{|c|c|}
\hline Fonte & Definição \\
\hline AURP $^{17}$ & $\begin{array}{l}\text { A definição da AURP engloba parques científicos e incubadoras } \\
\text { tecnológicas, considerando-os como: } \\
\text { - Áreas e prédios, existentes ou planejados, projetados, } \\
\text { principalmente, para instalações de pesquisa e } \\
\text { desenvolvimento, públicas e privadas, para empresas } \\
\text { baseadas em ciência e alta tecnologia, e para serviços de } \\
\text { apoio; } \\
\text { Possuem um contrato e/ou são de propriedade e mantêm um } \\
\text { relacionamento operacional com uma ou mais universidades } \\
\text { ou outras instituições de educação superior e pesquisa } \\
\text { científica; } \\
\text { Têm uma função de promoção de pesquisa e } \\
\text { desenvolvimento, por meio da universidade em parceria com } \\
\text { a industria, assessorando no crescimento de novos negócios, } \\
\text { e promovendo desenvolvimento econômico; } \\
\text { Têm uma função de auxiliar a transferência de tecnologia e } \\
\text { práticas de negócios entre a universidade e os arrendatários. } \\
\text { parque ou a incubadora podem ser entidades para fins } \\
\text { lucrativos ou sem fins lucrativos, de propriedade, total ou parcial, } \\
\text { da universidade ou de uma entidade relacionada à universidade. } \\
\text { Alternativamente, o parque ou a incubadora podem ser de } \\
\text { propriedade de uma entidade não-universitária, mas que tem } \\
\text { contrato ou uma relação formal com a universidade, incluindo } \\
\text { "joint venture" ou "cooperative venture" entre um parque } \\
\text { científico privado e a universidade. }\end{array}$ \\
\hline $\begin{array}{l}\text { Luis Sanz (Diretor } \\
\text { Geral da IASP) }\end{array}$ & $\begin{array}{l}\text { Um Parque Científico ou Tecnológico é um espaço, físico ou } \\
\text { cibernético, gerido por pessoal especializado, que provê serviços } \\
\text { com valor agregado, tendo por objetivo principal aumentar a } \\
\text { competitividade das regiões ou territórios sob sua influência, por } \\
\text { meio do estímulo à cultura da qualidade e inovação entre os } \\
\text { negócios associados e as instituições baseadas no } \\
\text { conhecimento, organizando a transferência de conhecimento e } \\
\text { tecnologia, de suas respectivas fontes para as empresas e o } \\
\text { mercado, fomentando a criação de novas e sustentáveis } \\
\text { empresas baseadas no conhecimento e processos de "spin-off". } \\
\text { Esta definição foi amplamente divulgada, e era utilizada pelo } \\
\text { autor antes que a IASP formalizasse sua versão oficial, em } \\
\text { fevereiro de } 2002 \text {, apresentada anteriormente nesta tabela. A } \\
\text { definição de Sanz envolve tanto a concepção de parques } \\
\text { científicos e tecnológicos como projetos baseados em } \\
\text { propriedades, como também as novas tendências de Parques } \\
\text { "virtuais". Outro importante aspecto trata-se da constatação de } \\
\text { que o conhecimento não é desenvolvido somente na } \\
\text { universidade ou centros de pesquisa, embora esses sejam } \\
\text { reconhecidamente atores importantes neste processo. A } \\
\text { definição de Sanz também contempla a idéia de que os parques } \\
\text { científicos e tecnológicos são instrumentos para apoiar o } \\
\text { desenvolvimento regional. }\end{array}$ \\
\hline
\end{tabular}

\footnotetext{
${ }^{17}$ AURP - Association of University Research Parks; disponível em: http://www. aurrp.org; acesso em 15/03/2003.

${ }^{18}$ Disponível em: http://www/iasp.ws/information/verdefinicion.php?idnot=7; acesso em 15/03/2003.
} 


\begin{tabular}{|c|c|}
\hline Fonte & Definição \\
\hline UKSPA $^{19}$ & $\begin{array}{l}\text { Um Parque Científico é uma iniciativa de apoio aos negócios e } \\
\text { de transferência de tecnologia que: } \\
\text { - Encoraja e apóia os negócios baseados em conhecimento, } \\
\text { promovendo seu crescimento; } \\
\text { - Provê um ambiente onde negócios grandes e internacionais } \\
\text { podem desenvolver interações específicas e próximas com } \\
\text { um centro de criação de conhecimento, para seu mútuo } \\
\text { benefício; } \\
\text { - Tem uma ligação formal e operacional com centros de } \\
\text { criação de conhecimento tais como universidades, institutos } \\
\text { de educação superior e organizações de pesquisa. }\end{array}$ \\
\hline
\end{tabular}

No interesse deste estudo, considera-se a terminologia de "Parque Tecnológico" para o modelo a ser desenvolvido, inseridas nesta terminologia também características de parques científicos, principalmente a estreita interação com o meio acadêmico. Adota-se a definição da IASP como a mais abrangente, adicionando-se a ela a visão de Sanz no que tange às novas tendências de formação de parques virtuais, bem como a realidade da diversificação das fontes de conhecimento, em diferentes tipos de organizações, gerando um fluxo multidirecionado de interação para a inovação e apoio ao desenvolvimento regional.

Duas abordagens interessantes, sob o ponto de vista de organização geográfica das experiências mais relevantes, foram encontradas durante 0 desenvolvimento deste estudo, são elas:

- A classificação histórico-geográfica de Sanz (1998), que aponta os seguintes modelos: o modelo californiano, o modelo britânico, o modelo do norte europeu ou escandinavo, o modelo mediterrâneo (sul europeu - França, Espanha, Itália e Portugal) e o modelo japonês; na TAB. 3.6, encontram-se as principais características dos modelos mencionados;

- Outra classificação está relacionada aos casos considerados mais relevantes, em termos de desenvolvimento regional, dentre as pesquisas realizadas por Benko (1991), Castells \& Hall (1994) apud Tavares (1998), que encontram-se na TAB. 3.7. Nessa tabela combinam-se as experiências selecionadas por cada um dos

\footnotetext{
${ }^{19}$ UKSPA - United Kingdom Science Park Association; disponivel em: http://www.ukspa.org.uk; acesso em 15/03/2003.
} 
autores Benko (1991) e Castells \& Hall (1994) apud Tavares (1998), consideradas as mais relevantes com relação aos efeitos positivos sobre as regiões de influência.

TABELA 3.6 - Características dos modelos de Parques Tecnológicos classificação histórico-geográfica de Sanz (1998)

\begin{tabular}{c}
\hline Modelo \\
Modelo Californiano
\end{tabular}
"Science Park")

(a Inglaterra apresentou um boom na implantação de parques científicos na década de 1980; o modelo inglês tem buscado se fortalecer principalmente por meio da participação ativa das universidades)

\section{Características}

São iniciativas promovidas, ou muito vinculadas, a Universidades;

- São ligadas a setores tecnológicos de ponta, emergentes e de altíssimo valor agregado;

- Aproveitam, ao máximo, a capacidade de atração da região, bem como o valor comercial das pesquisas desenvolvidas pelas Universidades, na criação de empresas;

- Trata-se de um fenômeno espontâneo, ou seja, não há um planejamento inicial; não existem intenções prévias de constituir-se em um elemento de desenvolvimento regional;

- Concentram a atenção sobre a criação de novas empresas (tecnológicas), por meio do "spin-off" de departamentos e laboratórios das Universidades, bem como das próprias empresas instaladas no Parque;

- São projetos auto-financiados, e autosuficientes, capazes, inclusive, de proporcionar retorno de investimento a seus promotores.

- São criados por universidades $e$ instalados em seus campi,

- São caracterizados por mínima presença de atividades industriais manufatureiras, centrandose em atividades de pesquisa de desenvolvimento, laboratórios de empresas, entre outras;

- As incubadoras de empresas são consideradas elementos importantes nos Parques (na concepção de que as incubadoras de empresas sejam concebidas para facilitar a criação de novas empresas, proporcionando apoio para estudos de viabilidade, formação empresarial, apoio logístico e assessoramento para os novos projetos empresariais).

\begin{tabular}{|c|c|}
\hline $\begin{array}{l}\text { Modelo Norte-Europeu } \\
\text { (também pode ser identificado } \\
\text { como "Modelo Escandinavo") } \\
\text { Este modelo e afeito não só } \\
\text { aos países escandinavos, mas } \\
\text { também a outras regiōes tais } \\
\text { como a Finlândia e Benelux; } \\
\text { foi também reproduzido fora da } \\
\text { Europa, com variações, na } \\
\text { Austrália e em alguns países } \\
\text { asiáticos. }\end{array}$ & $\begin{array}{l}\text { Modelo que deu certo em regiões de elevado } \\
\text { desenvolvimento econômico ou de grande } \\
\text { crescimento, e com uma cultura empresarial e } \\
\text { de livre concorrência bem consolidadas; } \\
\text { Trata-se do modelo que apresenta o maior } \\
\text { número de casos de êxito, pois conjuga, de } \\
\text { forma equilibrada, as melhores características } \\
\text { de outros modelos existentes; } \\
\text { Tem como características: } \\
\text { o Áreas de pequena a média extensão; } \\
\text { o Projetos promovidos com participação de }\end{array}$ \\
\hline
\end{tabular}




\begin{tabular}{|c|c|}
\hline Modelo & Características \\
\hline & $\begin{array}{l}\text { Universidades, organizações públicas (na } \\
\text { maioria das vezes as municipalidades) e } \\
\text { iniciativa privada; } \\
\text { Oferta reduzida de áreas, enfatizando-se o } \\
\text { oferecimento de edifícios (para venda, aluguel } \\
\text { ou leasing); } \\
\text { o Possuem equipes de gestão especializadas, } \\
\text { muito envolvidas nos aspectos de fomento à } \\
\text { transferência de tecnologia e à inserção } \\
\text { comercial no mercado internacional de } \\
\text { produtos e serviços de seus usuários. }\end{array}$ \\
\hline $\begin{array}{l}\text { Modelo Mediterrâneo } \\
\text { Desenvolvido em países do } \\
\text { Sul da Europa (França, } \\
\text { Espanha, Itália e Portugal), } \\
\text { baseado no modelo de Sophia- } \\
\text { Antipolis (Nice, França). } \\
\text { (A França, tem um modelo que se } \\
\text { baseia na forte presença dos } \\
\text { agentes governamentais, das } \\
\text { universidades, centros de } \\
\text { pesquisa e grandes empresas, } \\
\text { incluindo multinacionais; a } \\
\text { Península lbérica, cujo movimento } \\
\text { de implantação de parques de } \\
\text { ciência e tecnologia iniciou-se } \\
\text { mais tarde, na década de 1990, } \\
\text { tem como principal interesse para } \\
\text { este estudo o fato de se tratar de } \\
\text { regiōes emergentes em termos de } \\
\text { desenvolvimento econômico, } \\
\text { similar à situação brasileira.) }\end{array}$ & $\begin{array}{l}\text { Parques são geralmente promovidos por entidades } \\
\text { públicas (principalmente municipalidades, organizações } \\
\text { governamentais regionais); } \\
\text { São concebidos como instrumentos de desenvolvimento } \\
\text { regional; } \\
\text { Estão relacionados à ocupação de grandes áreas de } \\
\text { extensão. }\end{array}$ \\
\hline
\end{tabular}

TABELA 3.7 - Experiências selecionadas por Benko e Castells\&Hall

\begin{tabular}{l|l}
\hline \multicolumn{1}{c|}{ Experiência } & \multicolumn{1}{c}{ País } \\
\hline Vale do Silício & Estados Unidos da América \\
\hline Rodovia 128 & Estados Unidos da América \\
\hline Tsukuba & Japão \\
\hline Cité Scientifique Paris-Sud & França \\
\hline Sophia-Antipolis & França \\
\hline Cambridge & Inglaterra \\
\hline
\end{tabular}

Juntando-se a essas visões, destacam-se também as seguintes áreas onde essas experiências florescem: na América do Norte ressalyando ainda o advento dos parques tecnológicos metropolitanos canadenses; Israel, onde existe 
um esforço local no sentido de criação de incubadoras $\theta$ parques tecnológicos com o intuito de gerar novos postos de trabalho para os profissionais altamente qualificados disponiveis; a Coréia - o desenvolvimento coreano tem tido como atores-chave o forte investimento em educação (principalmente na formação de engenheiros e técnicos altamente qualificados) e na implementação de considerável infra-estrutura tecnológica, merecendo destaque os Parques de Ciência e Tecnologia; a Índia - na região de Bangalore, conhecida como o Silicon Valley da Índia, existem interessantes experiências - trata-se de uma região com elevada densidade tecnológica, com Institutos, Centros de Pesquisas e Universidades, bem como parques como o Software Technology Parks of India Bangalore. As tendências mostram que o movimento de parques tecnológicos se dissemina pelo mundo todo, com previsão de expansão nos próximos anos.

No Brasil o movimento de parques tecnológicos é tardio. Algumas experiências pioneiras foram lançadas nas décadas de 80-90. Essas experiências, em sua maioria, sofreram o impacto da descontinuidade de ações, da falta de políticas específicas para apoio a esse tipo de iniciativas, da resistência por parte dos ambientes acadêmicos-universitários, da falta de formalização, atuando, quase sempre, com características de incubadoras de empresas. Entre as primeiras iniciativas brasileiras encontram-se (Medeiros et al., 1992): A Fundação Parque Tecnológico da Paraíba (PAQTC-PB), em Campina Grande; A Companhia de Desenvolvimento do Pólo de Alta Tecnologia de Campinas (CIATEC), em São Paulo; o Parque de Software de Curitiba (CIC Companhia de Desenvolvimento de Curitiba); o Parque Alfa - Conselho das Entidades Promotoras do Pólo Tecnológico da Grande Florianópolis (CONTEC), em Santa Catarina; o Parque de Desenvolvimento Tecnológico (PADETEC) da Universidade Federal do Ceará (UFC), em Fortaleza; a Fundação Parque de Alta Tecnologia de São Carlos (PARQTEC-SCAR), em São Paulo.

De fato, pela primeira vez, a ANPROTEC, em sua publicação "Panorama 2002" (ANPROTEC, 2002, p. 32-33), apresenta um levantamento da situação dos parques tecnológicos no Brasil, apontando para um crescimento dessas iniciativas no Brasil a partir da década de 90 . As tendências do estudo mostram que deve haver uma considerável expansão de parques tecnológicos, nos próximos anos, disseminados em todas as regióes do país, com maior ocorrência nos estados das regiōes sul e sudeste. 
As mudanças com relação ao apoio político e para financiamento desses projetos no Brasil podem ser sentidas com o advento de programas governamentais recentemente lançados. Exemplifica-se, em nivel federal, no âmbito dos Fundos Setoriais do Ministério da Ciência e Tecnologia, a criação do Fundo Verde-Amarelo - Interação Universidade-Empresa. Este programa foi criado com o objetivo principal de "estimular o desenvolvimento tecnológico brasileiro, mediante programas de pesquisa científica e tecnológica que intensifiquem a cooperação de universidades, centros de pesquisa e institutos tecnológicos com o setor produtivo, contribuindo assim para acelerar o processo de inovação tecnológica no País."

O Fundo Verde-Amarelo foi instituído com base em um arcabouço legal bem desenvolvido, prevendo o recolhimento de recursos financeiros para prover o programa, a saber:

- Lei $n^{\circ} 10.168(29 / 12 / 2000)$ - institui a contribuição de intervenção de domínio econômico destinada a financiar o Programa de Estímulo à Interação Universidade-Empresa para $\circ$ Apoio à Inovação, e dá outras providências;

- Decreto $n^{0} 3.949$ (03/10/2001) - regulamenta a lei $n^{\circ} 10.168$;

- Portaria MCT 619 (24/10/2001) - institui o Comitê Gestor com a finalidade de administrar a aplicação dos recursos repassados ao Fundo nacional de Desenvolvimento Científico e Tecnológico FNDCT, para financiar atividades de pesquisa científica e desenvolvimento tecnológico do Programa de Estímulo à Interação Universidade-Empresa para o Apoio à Inovação;

- Lei $\mathrm{n}^{\circ} 10.332$ (19/12/2001) - institui mecanismo de financiamento para o Programa de Ciência e Tecnologia para o Agronegócio, para o Programa de Fomento à Pesquisa em Saúde, para o Programa de Biotecnologia e Recursos Genéticos - Genoma, para o Programa de Ciência e Tecnologia para o Setor Aeronáutico e para o Prógrama de Inovação para Competitividade, e dá outras providências.

${ }^{20}$ Disponivel em http://www.finep.gov.br/fundos_setoriais/verde amarelo/; acesso em 17/03/2003. 
$\mathrm{Na}$ chamada por edital do Fundo Verde-Amarelo referente especificamente aos Parques Tecnológicos, são contemplados dois grupos de apoio: ao Apoio à Elaboração de Plano de Investimento para Parques Tecnológicos e ao Apoio à Implantação de Parques Tecnológicos. Destaca-se, na regulamentação dos Editais, a obrigatória apresentação, nos projetos propostos, de contrapartida financeira por parte de instituições intervenientes correspondente a, no mínimo, $100 \%$ dos recursos solicitados ao FNDCT, muito embora possam ser considerados os aportes de recursos financeiros, aos projetos, realizados a partir de seis meses anteriores à data de lançamento do edital em questão. Tal exigência visa sedimentar as intenções das instituições intervenientes e parceiras com relação ao projeto proposto.

Outras legislações de apoio a projetos de Parques Tecnológicos começam a serem observadas no país, porém de caráter mais regional, como regulamentação de uso da terra, ações de incentivos fiscais, entre outras, que poderão ser vista, por exemplo, em algumas das iniciativas analisadas na pesquisa de campo associada a este estudo.

Como comentários finais, com relação a este item, observa-se uma diminuição progressiva das fragilidades institucionais e políticas registradas, com relação aos Parques Tecnológicos no Brasil, em décadas anteriores. As experiências internacionais bem sucedidas, entre elas estando algumas que já prestam serviços de consultoria a empreendimentos brasileiros em projeto e implantação, têm estimulado o desenvolvimento de novas iniciativas no país. No entanto, ainda são observadas algumas dificuldades que se colocam no caminho do desenvolvimento dos parques, entre elas:

- Maior coordenação entre as políticas de apoio aos empreendimentos, nos diversos níveis de governo (federal, estadual e municipal);

- Um arcabouço legal melhor desenvolvido para regulamentar às atividades de relação entre os empresários e as entidades acadêmicas e de pesquisa e estimular a participação destas entidades nas políticas de desenvolvimento baseado no conhecimento; 
- Formulação de estratégias para captação de interesse da iniciativa privada para apoio aos projetos e participação direta no seu desenvolvimento;

- Nos casos dos parques em regiōes urbanas, melhor articulação com Planos Diretores das cidades e inserção em políticas e planos de desenvolvimento regionais;

- Melhores políticas de comunicação e divulgação para esclarecimento da sociedade local e captação do seu interesse para os projetos.

\subsubsection{Principais organizações internacionais que agrupam e formam redes} de parques científicos e tecnológicos e principais indicadores mundiais relativos ao movimento

Conforme já foi introduzido no item anterior, paralelo ao fenômeno dos parques científicos e tecnológicos, surgem as associações, regionais, nacionais e internacionais, que agrupam esses empreendimentos, ou mesmo, formam redes.

Entre as principais associações destaca-se a Associação Internacional de Parques Científicos - a IASP $^{21}$, criada em 1984, sediada em Málaga, na Espanha, que pode ser considerada a associação de mais amplo espectro de atuação, no que concerne a regiões do mundo que agrega, estando presente em 57 países, por meio de seus associados. A IASP atua como uma rede mundial e, por isso mesmo, sua definição de parques científicos e tecnológicos procura englobar diversos modelos, tentando estabelecer um rol de requisitos mínimos para essas iniciativas.

A IASP é uma organização internacional sem fins lucrativos, independente e auto-suficiente sob o ponto de vista financeiro, que promove uma rede mundial de organizações e profissionais, baseados no conhecimento. Tem como principais objetivos:

- Auxiliar no desenvolvimento de novos Parques Científicos e Tecnológicos;

- Encorajar parcerias entre os diversos atores envolvidos em Parques Científicos e Incubadoras de Empresas;

\footnotetext{
${ }^{21}$ Todos os dados sobre a IASP, veiculados neste item, estão disponiveis em: http://www.iasp.ws.
} 
- Fomentar a formação de redes internacionais entre os seus membros;

- Incrementar a consciência sobre a importância e a abrangência dos Parques Científicos e Tecnológicos entre os tomadores de decisão e promotores de políticas públicas.

$\mathrm{Na}$ TAB. 3.8, encontram-se os principais dados estatísticos referentes à atuação da IASP, desde sua fundação.

Além da IASP, existem outras importantes associações, na maior parte de caráter nacional, entre as quais inclui-se a associação brasileira, a ANPROTEC. Na TAB. 3.9, encontra-se uma lista dessas associações, conforme dados veiculados pela IASP.

TABELA 3.8 - Dados Estatísticos referentes à IASP

\begin{tabular}{l|c}
\hline Número de membros (novembro/2002) & 251 \\
\hline Países que contam com membros da IASP & 57 \\
\hline Número de empresas instaladas por membros da IASP & 48.000 \\
\hline Membros do Conselho Internacional da IASP & 17 \\
\hline Número de membros da equipe da IASP (em Málaga e em & 7 \\
Beijing) & \\
\hline
\end{tabular}

TABELA 3.9 - Associações Nacionais e Regionais, no mundo, catalogadas pela IASP em sua página na Internet

\begin{tabular}{|c|c|c|}
\hline Nome da Associação & País & Página na Internet \\
\hline $\begin{array}{l}\text { AIPYPT-Asociación de } \\
\text { Incubadoras de Empresas, } \\
\text { Parques y Polos } \\
\text { Tecnológicos de la } \\
\text { República Argentina } \\
\end{array}$ & Argentina & www.aipypt.org.ar \\
\hline $\begin{array}{l}\text { ANZABI-Australian \& New } \\
\text { Zealand Association of } \\
\text { Business Incubation }\end{array}$ & $\begin{array}{l}\text { Australia e Nova } \\
\text { Zelândia }\end{array}$ & www.anzabi.com.au \\
\hline $\begin{array}{l}\text { Technology Parks and } \\
\text { Incubators Australia Ltd. }\end{array}$ & Australia & www.TechParksandlncubatorsAust.com \\
\hline $\begin{array}{l}\text { VTO-Association } \\
\text { Austrian of } \\
\text { Centers }\end{array}$ & Austria & www.vtow.inna.at \\
\hline $\begin{array}{lr}\text { EBN-European } & \text { Business } \\
\text { and Innovation } & \text { Centre } \\
\text { Network } & \\
\end{array}$ & Bélgica & www.ebn.be \\
\hline $\begin{array}{l}\text { ANPROTEC-Associação } \\
\text { Nacional de Entidades } \\
\text { Promotoras de } \\
\text { Empreendimentos de } \\
\text { Tecnologias Avançadas } \\
\end{array}$ & Brazil & www.anprotec.org.br \\
\hline BARDA-Bulgarian & Bulgaria & www barda.org \\
\hline
\end{tabular}




\begin{tabular}{|c|c|c|}
\hline Nome da Associação & País & Página na Internet \\
\hline $\begin{array}{l}\text { Association of Regional } \\
\text { Development Agencies and } \\
\text { Business Centers }\end{array}$ & & \\
\hline $\begin{array}{l}\text { BBIA-Beijing Business } \\
\text { Incubation Association }\end{array}$ & China & www.bjventure.net.cn \\
\hline $\begin{array}{ll}\text { CASTIP-China } & \text { Association } \\
\text { of Science \& } & \text { Technology } \\
\text { Industry Parks } & \\
\end{array}$ & China & www.chinatorch.gov.cn \\
\hline $\begin{array}{ll}\text { TEKEL-Finnish } & \text { Science } \\
\text { Park Association } & \\
\end{array}$ & Finlândia & www.tekel.fi \\
\hline $\begin{array}{l}\text { FTEI-France Technopoles } \\
\text { Enterprises Innovation }\end{array}$ & França & www.ftei.org \\
\hline $\begin{array}{l}\text { ADT-Arbeitsgemeinschaft } \\
\text { Deutscher Technologie - } \\
\text { und Gründerzentren e.V. }\end{array}$ & Alemanha & www.adt-online.de \\
\hline $\begin{array}{l}\text { VISZ-Entrepreneurial } \\
\text { Incubators Association } \\
\text { Hungary }\end{array}$ & Hungria & www.visz.hu \\
\hline $\begin{array}{l}\text { Association of EC Business } \\
\& \text { Innovation Centres in } \\
\text { Ireland }\end{array}$ & Irlanda & www.shannon-dev.ie \\
\hline $\begin{array}{l}\text { APSTI-Associazione Parchi } \\
\text { Scientifici e Tecnologici } \\
\text { Italiani }\end{array}$ & Itália & www.tno.it/apsti/aphome.htm \\
\hline $\begin{array}{l}\text { JANBO-Japan Association } \\
\text { of New Business Incubation } \\
\text { Organization }\end{array}$ & Japan & www.janbo.gr.jp \\
\hline 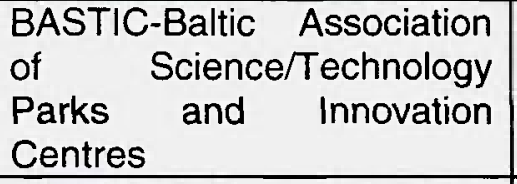 & Latvia & www.innovation.Iv/BASTIC.htm \\
\hline $\begin{array}{l}\text { AMIEPAT-Asociación } \\
\text { Mexicana de Incubadoras } \\
\text { de Empresas y Parques } \\
\text { Tecnológicos }\end{array}$ & México & www.dip.udg.mx/tecnopol.htm \\
\hline $\begin{array}{l}\text { The Norwegian Science } \\
\text { Park Association }\end{array}$ & Noruega & www.fin.no/fin/ \\
\hline $\begin{array}{l}\text { PBICA-Polish Business and } \\
\text { Innovation } \\
\text { Association }\end{array}$ & Polônia & www.sooipp.org.pl \\
\hline $\begin{array}{l}\text { TECNOPARQUES- } \\
\text { Associação Portuguesa de } \\
\text { Parques de Ciência e } \\
\text { Tecnologia } \\
\end{array}$ & Portugal & www.tecnoparques.pt \\
\hline AT-Association Technopark & Rússia & www.technopark.al.ru \\
\hline $\begin{array}{l}\text { KOBIA-Korean Business } \\
\text { Incubator Association }\end{array}$ & Coréia do Sul & www.kobia.or.kr \\
\hline $\begin{array}{lr}\text { APTE-Asociación } & \text { de } \\
\text { Parques Tecnológicos y } & \text { y } \\
\text { Científicos de España } & \\
\end{array}$ & Espanha & www.apte.org \\
\hline $\begin{array}{l}\text { SWEDEPARK-Swedish } \\
\text { Technology Parks in } \\
\text { Cooperation }\end{array}$ & Suécia & www.swedepark.se \\
\hline
\end{tabular}




\begin{tabular}{l|l|l}
\hline \multicolumn{1}{c|}{ Nome da Associação } & \multicolumn{1}{c}{ País } & \multicolumn{1}{c}{ Página na Internet } \\
\hline $\begin{array}{l}\text { UKSPA-The United } \\
\text { Kingdom Reino Unido } \\
\text { Association }\end{array}$ & www.ukspa.org.uk \\
\hline $\begin{array}{l}\text { United Kingdom Business } \\
\text { Incubation }\end{array}$ & Reino Unido & www.ukbi.co.uk \\
\hline $\begin{array}{l}\text { AURP-Association of } \\
\text { University Research Parks }\end{array}$ & Estados Unidos & www.aurrp.org \\
\hline $\begin{array}{l}\text { NBIA-National Business } \\
\text { Incubation Association }\end{array}$ & Estados Unidos & www.nbia.org \\
\hline
\end{tabular}

Outras formas de associações também têm sido observadas com relação aos parques científicos e tecnológicos no mundo. Além de participarem em associações nacionais e internacionais, muitos deles atuam ou formalizam alianças com outros parques, em outros países, baseadas em interesses comuns, na maior parte das vezes visando a internacionalização de suas empresas associadas, expandindo sua atuação em termos de operação e, até mesmo, proporcionando a criação de subsidiárias e escritórios regionais. Outro objetivo importante com essas alianças tem sido a promoção do desenvolvimento das regiões, de forma recíproca, ativando e promovendo mercados internacionais para produtos e serviços gerados nas localidades onde estão instalados os clusters ou parques. A promoção da internacionalização de suas empresas é considerada uma importante ação de promoção que a gestão do parque científico e tecnológico deve desenvolver, uma vez que amplia os horizontes de atuação das empresas, bem como apoio ao desenvolvimento regional, por meio da ampliação da atuação da região nos mercados globais.

Como um dos exemplos dessa aliança, pode-se citar a "The International Science Park Alliance", uma aliança formada entre quatro parques científicos e tecnológicos em diferentes continentes, sendo eles: The Oxford Science Park, The University Science Center (Philadelphia, EUA), Kyoto Research Park (Japão), The Australian Technology Park (Sydney, Austrália). Esta aliança foi estabelecida com os seguintes objetivos: estimular a troca de conhecimentos e tecnologias entre empresas instaladas nos parques; encorajar e auxiliar as empresas situadas nos parques a expandir suas operações, criando 
subsidiárias e escritórios em outros continentes; promover, reciprocamente, os parques nos territórios de influência ${ }^{22}$.

Abordando o tema dos indicadores mundiais do movimento de parques científicos e tecnológicos, admite-se que os dados veiculados pela IASP são os que apresentam o mais amplo espectro de informações sobre este assunto sendo, portanto, adotados por este estudo. Na TAB. 3.10, apresenta-se um breve resumo dos principais indicadores do movimento de parques científicos e tecnológicos no mundo.

TABELA 3.10 - Principais indicadores do movimento de parques científicos e tecnológicos no mundo ${ }^{23}$

\begin{tabular}{|c|c|c|}
\hline Indicador & Dados & Comentários \\
\hline $\begin{array}{l}\text { Criação de parques } \\
\text { C\&T (periodo) - } \\
\text { tendências do } \\
\text { movimento }\end{array}$ & $\begin{array}{l}1960-69: 2 \% \\
1970-79: 2 \% \\
1980-89: 30 \% \\
1990-99: 48 \% \\
2000-02: 18 \%\end{array}$ & $\begin{array}{l}\text { A maioria dos parques existentes no } \\
\text { mundo foi criada na década de } 90 \text {; } \\
\text { observe-se porem que, somente em } \\
\text { dois anos do novo século, foram } \\
\text { criados } 18 \% \text { dos parques, o que } \\
\text { confirma a tendência de crescimento } \\
\text { do movimento. }\end{array}$ \\
\hline $\begin{array}{l}\text { Áreas ocupadas por } \\
\text { parques C\&T, no } \\
\text { mundo }\end{array}$ & $\begin{array}{l}\text { Até } 200.000 \mathrm{~m}^{2}: 51 \% \\
200.000-600.000 \mathrm{~m}^{2}: 21 \% \\
600.000-1.000 .000 \mathrm{~m}^{2}: 5 \% \\
>1.000 .000 \mathrm{~m}^{2}: 20 \% \\
\text { (na pesquisa feita, } 2 \% \text { não } \\
\text { informaram a área) }\end{array}$ & $\begin{array}{l}\text { Observe-se que a maioria dos } \\
\text { parques possui áreas consideradas } \\
\text { de pequena a média }(71 \%) \text {, embora } \\
\text { haja uma ocorrência significativa de } \\
\text { modelos que ocupam grandes áreas } \\
\text { de extensão }(20 \%) \text {. }\end{array}$ \\
\hline $\begin{array}{l}\text { Área construída nos } \\
\text { parques C\&T }\end{array}$ & $\begin{array}{l}\text { Até } 15.000 \mathrm{~m}^{2}: 27 \% \\
15.000-40.000 \mathrm{~m}^{2}: 22 \% \\
40.000-80.000 \mathrm{~m}^{2}: 14 \% \\
>80.000 \mathrm{~m}^{2}: 35 \% \\
\text { (na pesquisa feita, } 2 \% \text { não } \\
\text { informaram a área } \\
\text { construída) }\end{array}$ & $\begin{array}{l}\text { Observe-se que } 49 \% \text { possuem área } \\
\text { construida de pequeno a médio porte } \\
\text { e que } 49 \% \text { possuem áreas } \\
\text { construídas de médio a grande } \\
\text { portes. Os modelos, com relação a } \\
\text { áreas construídas, podem apresentar } \\
\text { alta densidade de edificações. } \\
\text { Conforme as estatisticas da IASP, } \\
39 \% \text { dos parques no mundo } \\
\text { apresentam áreas verdes em mais de } \\
30 \% \text { de seu território. }\end{array}$ \\
\hline $\begin{array}{l}\text { Planos para } \\
\text { expansão dos } \\
\text { parques C\&T }\end{array}$ & $\begin{array}{l}89 \% \text { têm intenções de } \\
\text { expandir o parque; } \\
10 \% \text { não têm intenções de } \\
\text { expandir o parque; } \\
\text { (na pesquisa feita, 1\% não } \\
\text { informou a intenção) }\end{array}$ & $\begin{array}{l}\text { Observe-se que a maioria dos } \\
\text { parques tem intenções de expandi- } \\
\text { los. Esta expansão pode-se dar por } \\
\text { agregação de novos terrenos, } \\
\text { construção de novas instalações para } \\
\text { arrendamento ou venda, entre outras } \\
\text { iniciativas. }\end{array}$ \\
\hline $\begin{array}{l}\text { Número de } \\
\text { integrantes, } \\
\text { conntĥminns nns }\end{array}$ & $\begin{array}{l}\text { Menos de } 50: 53 \% \\
50-100: 18 \%\end{array}$ & $\begin{array}{l}\text { Observe-se que os parques C\&T } \\
\text { privilegiam a qualidade (e não a } \\
\text { quantidade) de seus residentes, }\end{array}$ \\
\hline
\end{tabular}

${ }^{22}$ As informações sobre os parques mencionados e a aliança podem ser encontrados em: http://www.oxfordsp.com/ ; acesso em: 18/03/2003.

${ }^{28}$ As estatísticas sobre parques científicos e tecnológicos no mundo, baseadas nas pesquisas realizadas pela IASP, encontram-se disponiveis em: http://www.laspworld.org/information.php. Acesso em: 17/03/2003. A maior parte dos dados é de novembro de 2002. 


\begin{tabular}{|c|c|c|}
\hline Indicador & Dados & Comentários \\
\hline $\begin{array}{l}\text { condôminos, nos } \\
\text { parques C\&T } \\
\text { (incluindo empresas } \\
\text { e outras } \\
\text { organizações) }\end{array}$ & $\begin{array}{l}\text { 101-200: } 18 \% \\
201-400: 5 \% \\
>400: 4 \% \\
\text { (na pesquisa feita, } 2 \% \text { nāo } \\
\text { informaram o número de } \\
\text { condôminos) }\end{array}$ & $\begin{array}{l}\text { tendo em vista que } 53 \% \text { têm até } 50 \\
\text { integrantes e que } 36 \% \text { têm entre } 50 \text { e } \\
200 \text { integrantes. }\end{array}$ \\
\hline $\begin{array}{l}\text { Empregos gerados } \\
\text { nos parques C\&T }\end{array}$ & $\begin{array}{l}\text { Menos de } 300: 42 \% \\
\text { 300-800: } 10 \% \\
801-1500: 12 \% \\
\text { 1501-3000: } 13 \% \\
>3000: 21 \%\end{array}$ & $\begin{array}{l}\text { Observe-se que os parques C\&T } \\
\text { geram, em sua maioria, até } 1500 \\
\text { empregos, sendo que } 42 \% \text { deles } \\
\text { geram até } 300 \text { empregos, sendo } \\
\text { portanto, geradores de postos de } \\
\text { trabalho para a região em que atuam, } \\
\text { principalmente para a mão-de-obra } \\
\text { qualificada.. }\end{array}$ \\
\hline $\begin{array}{l}\text { Localização } \\
\text { parques C\&T }\end{array}$ & $\begin{array}{l}\text { Áreas não urbanas: } 1 \% \\
\text { Próximo a cidades pequenas: } \\
5 \% \\
\text { Próximo a cidades médias: } \\
4 \% \\
\text { Próximo a cidades grandes } \\
\text { (até } 25 \mathrm{~km} \text { ): } 15 \% \\
\text { Em cidades pequenas (até } \\
500.000 \text { habitantes): } 44 \% \\
\text { Em cidades médias ( } 500.000- \\
1 \text { milhão de habitantes): } 7 \% \\
\text { Em cidades grandes } \\
\text { (> 1milhão de habitantes): } \\
24 \%\end{array}$ & $\begin{array}{l}\text { Observe-se que a grande maioria dos } \\
\text { parques (75\%) está localizada em } \\
\text { cidades. O maior número de parques } \\
\text { urbanos está relacionado a cidades } \\
\text { pequenas com até } 500.000 \\
\text { habitantes. }\end{array}$ \\
\hline $\begin{array}{lr}\text { Localização } & \text { dos } \\
\text { parques C\&T } & \text { com } \\
\text { relação } & \text { às } \\
\text { universidades } & \end{array}$ & $\begin{array}{l}\text { Localizados dentro do } \\
\text { campus: } 27 \% \\
\text { Localizados em terrenos da } \\
\text { universidade, porém não } \\
\text { dentro do campus: } 17 \% \\
\text { Localizados em outros } \\
\text { lugares: } 50 \% \\
\text { (na pesquisa } 6 \% \text { não deram } \\
\text { informações sobre este item) }\end{array}$ & $\begin{array}{l}\text { Observe-se que } 44 \% \text { dos parques } \\
\text { estão localizados em terrenos de } \\
\text { universidades, confirmando a estreita } \\
\text { relação entre os parques e as } \\
\text { universidades. }\end{array}$ \\
\hline $\begin{array}{lr}\text { Distância } & \text { dos } \\
\text { parques C\&T } & \text { com } \\
\text { relação } & \text { às } \\
\text { universidades } & \end{array}$ & $\begin{array}{l}\text { Localizados no campus ou } \\
\text { adjacentes a ele: } 48 \% \\
\text { Localizados próximo à } \\
\text { universidade (até } 5 \mathrm{~km} \text { ): } 28 \% \\
\text { De } 5-20 \mathrm{~km} \text { da universidade: } \\
11 \% \\
\text { Mais de } 20 \mathrm{~km} \text { da } \\
\text { universidade: } 4 \% \\
\text { (na pesquisa } 9 \% \text { não } \\
\text { informaram sobre este item) }\end{array}$ & $\begin{array}{l}\text { Observe-se que } 76 \% \text { das ocorrências } \\
\text { de parques C\&T estão muito } \\
\text { próximas das universidades, } \\
\text { corroborando o que foi dito no item } \\
\text { anterior. }\end{array}$ \\
\hline $\begin{array}{l}\text { Ações e interesses } \\
\text { que os parques C\&T } \\
\text { compartilham com } \\
\text { as universidades }\end{array}$ & $\begin{array}{l}\text { Escritório de Transferência de } \\
\text { Tecnologia instalado no } \\
\text { parque: } 33 \% \\
\text { Pesquisadores no parque: } \\
66 \% \\
\text { Compartilhamento de } \\
\end{array}$ & $\begin{array}{l}\text { E interessante ressaltar o fato de que } \\
33 \% \text { das universidades preferem que } \\
\text { seus escritórios de transferência de } \\
\text { tecnologia estejam localizados no } \\
\text { parque, como forma de aproximar-se } \\
\text { dos seus clientes. }\end{array}$ \\
\hline
\end{tabular}




\begin{tabular}{|c|c|c|}
\hline Indicador & Dados & Comentários \\
\hline & $\begin{array}{l}\text { serviços com a universidade: } \\
68 \% \\
\text { Compartilhamento de infra- } \\
\text { estrutura científica: } 49 \%\end{array}$ & 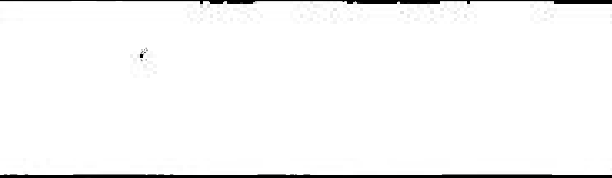 \\
\hline $\begin{array}{l}\text { Equipe de gestão do } \\
\text { parque C\&T } \\
\text { (número de } \\
\text { empregados } \\
\text { trabalhando em } \\
\text { tempo integral) }\end{array}$ & $\begin{array}{r}1-5: 34 \% \\
6-10: 31 \% \\
11-15: 15 \% \\
16-20: 7 \% \\
>20: 13 \%\end{array}$ & $\begin{array}{l}\text { Observe-se que as equipes de gestão } \\
\text { dos parques são bem enxutas, sendo } \\
\text { que } 65 \% \text { deles têm equipes de } \\
\text { gestão de até } 10 \text { empregados. }\end{array}$ \\
\hline $\begin{array}{l}\text { Tipo de } \\
\text { empreendimentos e } \\
\text { empreendedores } \\
\text { nos parques C\&T }\end{array}$ & $\begin{array}{l}\text { Empresas de serviços: } 51 \% \\
\text { Empresas industriais: } 18 \% \\
\text { Atividades de pesquisa } \\
\text { (básica e aplicada): } 26 \% \\
\text { Outras: } 5 \%\end{array}$ & $\begin{array}{l}\text { A maior parte das empresas situadas } \\
\text { nos parques são de serviços. }\end{array}$ \\
\hline $\begin{array}{l}\text { Estágio em que as } \\
\text { empresas vão para } \\
\text { os parques C\&T }\end{array}$ & $\begin{array}{l}\text { Empresas já existentes que } \\
\text { vão para o parque: } 54 \% \\
\text { Novas empresas: } 29 \% \\
\text { Empresas nascidas em } \\
\text { incubadoras: } 10 \% \\
\text { "spin-offs": } 7 \%\end{array}$ & $\begin{array}{l}\text { Os dados são de novembro de } 2001 \text {. } \\
\text { A IASP declara que em pesquisas } \\
\text { mais recentes, o número de ex- } \\
\text { incubados e de "spin-off" vêm } \\
\text { crescendo nos parques C\&T. }\end{array}$ \\
\hline $\begin{array}{l}\text { Setores } \\
\text { tecnológicos } \\
\text { preponderantes nos } \\
\text { parques C\&T }\end{array}$ & $\begin{array}{l}\text { Tecnologia da informação e } \\
\text { comunicações: } 26 \% \\
\text { Biotecnologia e ciências da } \\
\text { vida: } 20 \% \\
\text { Eletrônica e computadores: } \\
19 \% \\
\text { Setor agro-alimentar: } 9 \% \\
\text { Meio ambiente: } 8 \% \\
\text { Novos materiais: } 6 \% \\
\text { Farmacêuticos: } 5 \% \\
\text { Outros: } 7 \%\end{array}$ & $\begin{array}{l}\text { Observe-se que tecnologia de } \\
\text { informação, biotecnologia e eletrônica } \\
\text { e computação são as áreas mais } \\
\text { privilegiadas nos parques C\&T, } \\
\text { confirmando as tendências mundiais } \\
\text { de mercados. }\end{array}$ \\
\hline
\end{tabular}

\subsubsection{Breve revisão da experiência do Vale do Silício (Califórnia - Universidade de Stanford)}

É interessante colocar, neste momento, uma breve discussão sobre a experiência que é considerada a precursora dos parques científicos e tecnológicos. $E$, neste caso, não se faz aqui uma revisão de dados históricos sobre o parque de Stanford, já amplamente divulgados, porém realiza-se uma análise, por intermédio de estudos de alguns especialistas no tema (Saxenian, 1996; Murphy, 1997) do seu desenvolvimento e visão de futuro para o empreendimento.

Segundo Saxenian (1996), que em seu livro "Regional Advantage Culture and Competition in Silicon Valley and Route 128' faz uma análise 
comparativa entre esses dois fenômenos, o sucesso do Vale do Silício, na Califórnia, se deve, em grande parte, ao estilo descontraído e de busca de resultados que acabou por atrair os maiores cérebros, as melhores idéias e também, no arrasto dos acontecimentos, capitalistas (na maioria capital de risco), criando um modelo industrial, com diversos tipos de combinações possíveis, funcionando como uma rede. Este ambiente aberto e a infra-estrutura de conhecimento disponivel proporcionaram as condições necessárias, dinâmicas, para a geração de tecnologias, cada vez mais inovadoras, ultrapassando, no caso da comparação feita por Saxenian, o fenômeno da "Route 128". Por outro lado, as empresas da "Route 128" atuaram sempre buscando a regulamentação, ações protecionistas e a maior participação de recursos financeiros federais (como política de apoio à competitividade) nas atividades de P\&D desenvolvidas na região, tendo afugentado a inserção de dinheiro novo (privado) na região (Massachussets) quando, após os esforços mencionados, já haviam sido reenergizadas áreas competitivas e captados recursos federais para desenvolvimento.

O sucesso do Vale do Silício já transpôs fronteiras. Observa-se, em termos internacionais, uma busca por imitar esse modelo em diversas regiões, tais como: no Japão, que desenvolve a "Ilha do Silício" em Kyushu; Taiwan, que está criando uma "Ilha do Silício" própria; a Coréia que tenta criar a "Península do Silício" (Ohmae, 1999). A lição que se tira dessa exposição, segundo Saxenian (1996) é que devem ser desenvolvidas políticas que possam auxiliar as empresas a reagir rapidamente às mudanças provocadas pelos mercados e não protegê-las e isolá-las da concorrência e dos impactos externos.

Zera Murphy (1997), então Diretora de Administração e Relações Empresarias da Universidade de Stanford, em seu trabalho, aborda a decisão de desenvolver um plano estratégico para o parque tecnológico de Stanford, preparando o futuro do empreendimento. Aborda-se este estudo na presente pesquisa pelo fato de que, mesmo um empreendimento de sucesso, necessita ser periodicamente avaliado e ter seus rumos re-direcionados de forma a adequá-los às necessidades de seus clientes e aos anseios de suas comunidades afins.

Segundo Murphy (1997), uma das maiores vantagens apresentadas pelo parque tecnológico é a localização, adjacente a Stanford: 
"...é na realidade essa localização associada ao desenvolvimento de vínculos adicionais com a universidade, que garante ao parque um nicho de mercado e permite que ele seja muito mais resistente à recessão do que os muitos parques empresariais do mercado. Especificamente, durante o nosso estudo, percebemos que os parques tecnológicos verdadeiramente bem-sucedidos e flexíveis apresentam uma combinação das seguintes características importantes:

- Infra-estrutura e benfeitorias de alta qualidade;

- Uma base científica ou de pesquisa voltada para o futuro;

- Forte vínculo com uma universidade ou com um complexo de pesquisa; $e$

- Grandes arrendatários com um foco ou natureza especializados." (Murphy, 1997)

Como resultado dos estudos para o Plano Estratégico (com ampla participação da comunidade e com apoio de consultores especializados) mencionado por Murphy, são apontados os seguintes aspectos (vide Murphy, 1997, p. 17):

- O parque tem uma sólida posição no mercado principalmente por causa do seu vínculo com a Universidade de Stanford;

- A vantagem competitiva do parque é constantemente desafiada por outros locais (nacionais e internacionais) que oferecem melhores condições para os arrendatários (melhores preços, melhores instalações, mais próximos a regiões residenciais);

- Os vínculos acadêmicos são fortes em nível individual. As empresas têm gerado uma quantidade limitada de pesquisas patrocinadas na Universidade (o que entra de recursos significativos são resultado de doações, que também são feitas em equipamentos);

- Existe uma falta de identidade do parque, e mesmo algumas pessoas que nele trabalham não estão cientes das atividades do parque.

- A política inconstante sobre políticas de arrendamento e de gerenciamento de resíduos tóxicos gera problemas com os arrendatários;

- Desenvolve-se uma atuação conjunta da cidade de Palo Alto, a Universidade de Stanford e as empresas do parque no sentido de 
fazer frente aos déficits orçamentários e para estabelecer políticas locais para o crescimento da região.

Segundo a autora, e concluindo o tema, originalmente a universidade tinha um papel muito voltado ao investidor imobiliário, posição esta que, no Plano Estratégico proposto, está sendo mudada para uma atitude mais ativa e empreendedora. No entanto, é preciso que se diga, que os fatores de sucesso do empreendimento continuam basicamente os mesmos: idéias simples, que levem a atuações de longo termo, tais como - formalização de alguns novos programas para atração de interesse para a infra-estrutura da Universidade e de vínculos não-acadêmicos que captem o interesse da comunidade para o sucesso do parque, estabelecer alianças em outros países por meio da atuação internacional da Universidade de Stanford, e melhorar as condições de estacionamento no campus (aliás, este é um problema enfrentado por diversos parques no mundo, segundo pode ser observado durante o desenvolvimento desta pesquisa).

\subsubsection{Aspectos positivos e negativos do movimento de parques científicos e tecnológicos}

Concluindo o item 3.3, realiza-se, neste texto, um paralelo entre os aspectos positivos e os negativos relacionados ao movimento dos parques científicos e tecnológicos.

Nos primórdios do advento de modelos de parques científicos e tecnológicos o principal objetivo dessas iniciativas estava, quase sempre, direcionado ao incremento da transferência de tecnologia do meio acadêmico para o meio empresarial. Com a evolução do movimento, houve uma alteração positiva na abordagem dessas iniciativas, passando as mesmas a atuar em atividades de amplo aspecto, relacionadas ao apoio às empresas e, em decorrência, havendo maior interação com políticas de desenvolvimento econômico e social das regiões. Como conseqüência dessa evolução, surgem e se disseminam diversos modelos de parques científicos e tecnológicos, constatando-se que a eficiência e os resultados desses dependem de uma série de fatores, estando entre eles desde aspectos relacionados à gestão dos parques até a aproximação com as políticas e características sócio-econômicas das regiões de influência, bem como fatores de localização, sendo a proximidade com 
instituições de pesquisa considerada importante para a captação de interesse para o projeto e para o sucesso dos empreendimentos.

Estudiosos do tema, entre eles Luis Sanz (2001), concordam que o principal objetivo estratégico dos parques científicos e tecnológicos na atualidade é facilitar o acesso de suas empresas, e das regiões, à Economia do Conhecimento. Luiz Sanz apresenta sua argumentação neste sentido, fazendo uma comparação entre a atuação dos parques científicos e tecnológicos e uma granja, inferindo a idéia de que os parques seriam uma "Granja do Conhecimento". Na TAB. 3.11 encontra-se o paralelo elaborado por Sanz entre os processos de uma granja e sua produção agrícola e os parques científicos e tecnológicos.

TABELA 3.11 - Parques Científicos e Tecnológicos - "Granjas do Conhecimento" (Sanz, 2001)

\begin{tabular}{|c|c|c|}
\hline $\begin{array}{c}\text { Granja } \\
\text { (produtos agrícolas) }\end{array}$ & $\begin{array}{l}\text { Parques C\&T } \\
\text { Conhecimento }\end{array}$ & \\
\hline Arar e preparar a terra & $\begin{array}{l}\text { Preparar a infra-estrutura adequada (física ou } \\
\text { virtual) }\end{array}$ & \\
\hline Semear & $\begin{array}{l}\text { Metodologia de incubação ou spin-off } \\
\text { Capital semente } \& \text { capital de risco } \\
\text { Vínculos com a universidade } \\
\text { Atração de novos investimentos industriais } \\
\text { Programas de formação ad hoc }\end{array}$ & $\begin{array}{l}\text { As sementes } \\
\text { conhecimento }\end{array}$ \\
\hline $\begin{array}{l}\text { Fertilizar e cuidar da } \\
\text { planta }\end{array}$ & $\begin{array}{l}\text { Serviços com valor agregado } \\
\text { Redes e trabalho em rede }\end{array}$ & \\
\hline A colheita & $\begin{array}{l}\text { Empresas incubadas com êxito } \\
\text { Desenvolvimento de produtos/serviços inovadores } \\
\text { Patentes }\end{array}$ & $\begin{array}{l}\text { Empresas baseadas } \\
\text { no conhecimento }\end{array}$ \\
\hline Distribuição e venda & $\begin{array}{l}\text { Transferência de conhecimento } \\
\text { Transferência de tecnologia } \\
\text { Vendas (offe on-line), licenças e franquias }\end{array}$ & $\begin{array}{l}\text { Conhecimento global } \\
\text { Mercados globais }\end{array}$ \\
\hline
\end{tabular}

Não obstante os inúmeros aspectos positivos apresentados sobre os parques científicos e tecnológicos, observa-se que existe ainda um longo caminho a seguir. Aproveita-se, encerrando a discussão sobre o tema, a análise de Sanz (1998) a respeito dos aspectos negativos das experiências de parques científicos e tecnológicos, realizando um balanço necessário e importante para os formuladores de novos projetos e de políticas que envolvem essas experiências (vide TAB. 3.12). 
TABELA 3.12 - Parques científicos e tecnológicos - balanço entre aspectos positivos e negativos (Sanz, 1998)

\begin{tabular}{|c|c|}
\hline Aspectos positivos & Aspectos negativos \\
\hline $\begin{array}{l}\text { São impulsionadores de uma maior } \\
\text { consciência social e coletiva sobre a } \\
\text { importância dos papéis da tecnologia e da } \\
\text { inovação. }\end{array}$ & $\begin{array}{l}\text { A contrapartida do apoio público aos } \\
\text { parques (sem o qual não teriam sido } \\
\text { criados), é de uma freqüente e excessiva } \\
\text { "dependência" política, com um prejudicial } \\
\text { cerceamento da liberdade de gestão com } \\
\text { critérios empresariais. }\end{array}$ \\
\hline $\begin{array}{l}\text { Criaram e aperfeiçoaram, juntamente com } \\
\text { as incubadoras, uma série de metodologias } \\
\text { para a criação de novas empresas } \\
\text { inovadoras (spin-offe outros processos). }\end{array}$ & $\begin{array}{l}\text { A vinculação prática e real com as } \\
\text { universidades é, em muitos casos, menor } \\
\text { do que o desejável e, inclusive, insuficiente. }\end{array}$ \\
\hline $\begin{array}{l}\text { Adotaram e desenvolveram o conceito de } \\
\text { trabalho em rede (e pela globalização). }\end{array}$ & $\begin{array}{l}\text { Com freqüência se detecta um excessivo } \\
\text { peso do aspecto "imobiliário", em } \\
\text { detrimento de outros aspectos que } \\
\text { realmente agregam valor às empresas. }\end{array}$ \\
\hline $\begin{array}{l}\text { Contribuíram para a introdução da cultura } \\
\text { de qualidade na gestão global das } \\
\text { empresas. }\end{array}$ & $\begin{array}{l}\text { Pequena presença (os parques não a } \\
\text { fomentam suficientemente) de iniciativas de } \\
\text { capital semente e de capital de risco } \\
\text { vinculados ao projeto do parque e a suas } \\
\text { empresas. }\end{array}$ \\
\hline $\begin{array}{l}\text { Contribuíram, em geral, para um impacto } \\
\text { positivo em suas regiōes de influência, e } \\
\text { não somente para as empresas instaladas } \\
\text { em suas dependências (este fenômeno é } \\
\text { mais claro em regiões de baixo ou médio } \\
\text { desenvolvimento econômico). }\end{array}$ & $\begin{array}{l}\text { Freqüentes confusões a respeito do papel } \\
\text { dos parques na captação de investimentos } \\
\text { internacionais para sua região. }\end{array}$ \\
\hline
\end{tabular}

\subsection{Desenvolvimento urbano e as megacidades globais: as características} regionais da cidade de São Paulo e da região da Cidade Universitária

"A globalização não é um processo novo nem sinônimo necessariamente de modernidade ou qualidade de vida...O lado positivo da cidade global... só existe em partes da cidade, mesmo entre as líderes da globalização. Estamos falando de Manhattan e da London City. Ou, quando se trata de São Paulo, da Paulista, da Oscar Freire, dos Jardins, da Berrini."

(S.R.Schiffer, 1997) ${ }^{24}$

"If you live in a city, you have no choice but to share the same urban environment with millions of impoverished, dispossessed people. No one can ignore the issues of migrant people and city slums".

$$
\text { (M. Sato, 2001) })^{25}
$$

"Alguns estudiosos da cidade falam de uma era pós-industrial, de uma cidade pós-industrial onde tempo e espaço são redefinidos.

\footnotetext{
${ }^{24}$ Texto extraído de entrevista com a arquiteta e pesquisadora Sueli Ramos Schiffer, para a revista "Notícias FAPESP", n²3, agosto de 1997, p. 126.

${ }^{25}$ Texto extraído de entrevista com a pesquisadora do United Nations Centre for Human Settlements (Habitat) para a revista "Network", uma publicação oficial da Japan International Cooperation Agency (JICA), v. 13, outubro de 2001, p. 4.
} 
Nela não existe mais a necessidade de concentração, uma vez que sob o paradigma eletrônico-nuclear os terminais e bancos de dados podem estar dispersos pelo território. Por isso a cidade pode, pela primeira vez em sua história, não ser mais imã, rompendo seu impulso originário. Se isso corresponde a um mundo transformado inteiramente em cidade, a um mundo sem cidades ou ao mundo depois das cidades, só o futuro poderá dizer."

(R. Rolnik, 1995) ${ }^{26}$

“...A filosofia reencontra o médium (meio e mediação) de seus primórdios - a Cidade - numa escala colossal e completamente isolada da natureza. $A$ arte, também reconhece suas condiçóes iniciais, dirigese para um novo destino, o de servir à sociedade urbana e à vida quotidiana nessa sociedade. Quanto às ciências, não podem evitar o confronto com esse novo objeto sem que renunciem a sua especificidade, deixando o campo livre para uma delas...Elas travam contato...com uma exigência de totalidade e de síntese. Fato que obriga a conceber uma estratégia do conhecimento, inseparável da estratégia politica, ainda que distinta dela. Segundo qual eixo e em que horizontes pensar essa estratégia do saber? Na direção da entrada para a prática de um direito: o direito à cidade...à vida urbana, condição de um humanismo e de uma democracia renovados."

(H. Lefebvre, 2001)

Neste item são apresentadas as características da região da cidade de São Paulo e do entorno da Cidade Universitária, considerando os aspectos de desenvolvimento urbano de megacidades globais, como é o desta cidade.

A organização deste item está assim estruturada:

- Item 3.4.1 - breve abordagem sobre o fenômeno das "megacidades" globais e seus impactos na prosperidade das nações, inserindo a cidade de São Paulo neste contexto;

- Item 3.4.2 - breve comentário sobre a classificação da rede urbana brasileira e o processo de configuração das metrópoles no Brasil;

- Item 3.4.3 - características das regiões metropolitanas do Estado de São Paulo; os movimentos urbanos na Grande São Paulo;

- Item 3.4.4 - as regiões vizinhas à Cidade Universitária características gerais e perspectivas.

\subsubsection{Mega cidades globais e seus impactos na prosperidade das nações}

A rápida urbanização do mundo e seus impactos nas nações e na vida das pessoas nos aglomerados urbanos tem sido discutida por órgãos internacionais e pesquisadores. As cidades são consideradas focos da civilização

\footnotetext{
${ }^{26}$ Rolnik, R. O que é cidade. São Paulo: Brasiliense, 1995, p.84.
} 
e, ao mesmo tempo, fontes de problemas sociais, corrupção e outros males da sociedade moderna. A grande questão entre os pesquisadores está em como tornar operacionais essas mega cidades, como transformá-las em regiões que contribuam para a prosperidade das nações e de suas populações. Os números impressionam: por volta do ano 2030 , sessenta por cento da população mundial estará habitando regiões urbanas (Zwingle, 2002).

O crescimento demográfico mundial tem seus números mais expressivos nas cidades de países em desenvolvimento que, de forma geral, são os menos equipados para proporcionar meios de transporte, habitação, água e esgoto (saneamento básico), entre outros serviços. As Nações Unidas, nos trabalhos de preparação da United Nations Conference on Human Settlements Habitat II, levantou dados estatísticos (UNCHS, 2001) que comprovam essa tendência.

Entre as informações disponibilizadas encontram-se:

- O número total de aglomerações urbanas com população de 500.000 habitantes ou mais era de 438 em 1980; por volta do ano 2010, este número deverá mais que dobrar, alcançando 892 aglomerações urbanas e o número de pessoas residindo nessas cidades crescerão cinco vezes, de 745 milhões para 3,8 bilhões de pessoas;

- Em 1950, apenas três das dez maiores cidades do mundo estavam localizadas em países em desenvolvimento (Shanghai, Buenos Aires e Calcutá); em 1990, outras quatro cidades daqueles países foram adicionadas a esta estatística (Beijin, Bombaim, Cidade do México e São Paulo). Por volta do ano 2010, é estimado que oito das dez maiores cidades estarão nos países em desenvolvimento.

Em levantamento feito pela Prefeitura de São Paulo (utilizando como fontes relatórios das Nações Unidas, do Instituto Brasileiro de Geografia e Estatística - IBGE e pela Fundação SEADE), apresentado na TAB. 3.13, são identificados como maiores aglomerados urbanos do mundo, em 2000, as seguintes cidades: Tóquio, Cidade do México, Bombaim, São Paulo (aqui considerando a região metropolitana de São Paulo), Nova lorque, Lagos, Los Angeles, Calcutá, Xangai e Buenos Aires. 
TABELA 3.13 - Maiores aglomerados urbanos do mundo em $2000^{27}$

\begin{tabular}{c|c|c}
\hline Aglomerados Urbanos $^{28}$ & Países & População (em milhões) \\
\hline Tóquio & Japão & 26,4 \\
\hline Cidade do México & México & 18,1 \\
\hline Bombaim & India & 18,1 \\
\hline $\begin{array}{c}\text { Região Metropolitana de São } \\
\text { Paulo }\end{array}$ & Brasil & 17,8 \\
\hline Nova lorque & Estados Unidos & 16,6 \\
\hline Lagos & Nigéria & 13,4 \\
\hline Los Angeles & Estados Unidos & 13,1 \\
\hline Calcuta & India & 12,9 \\
\hline Xangai & China & 12,9 \\
\hline Buenos Aires & Argentina & 12,6 \\
\hline
\end{tabular}

As megalópoles, conforme comentado pelo pesquisador urbanista Greg Whiley para a Megacities 2000 Foundation (MEGACITIES, 2001), uma fundação criada em 1994 por intermédio da ação da UNESCO junto à Academy of Architecture (USA), são fruto de movimentos ocorridos principalmente a partir da segunda metade do século 20 , onde a população rural se deslocou para um ou dois principais centros urbanos nos países. Elas contam com uma população de mais de 10 milhões de pessoas e, como já foi comentado, com tendência de rápido crescimento. Por volta do ano 2015 algumas mega cidades poderão ter uma população de mais de 20 milhões de habitantes, tais como: Cidade do México e São Paulo, na América Latina, Lagos e Cairo na África, Karachi, Deli, Bombaim, Calcutá, Beijin, Shanghai e Jakarta na Ásia.

Os números das grandes aglomerações, apresentados neste item, remetem para uma discussão sobre a atividade econômica, nessas cidades, e seus impactos regionais e nacionais, considerando os mercados globais. Quais seriam então os fatores necessários para caracterizar essas megalópoles como megacidades globais?

Para ser uma megacidade global o fator importante não é a densidade de população e sim a concentração de empresas do setor financeiro e de atividades de serviço de ponta que acumulam conhecimento, e que são capazes de atrair investimentos de alto valor agregado. Essas cidades-região constituem

\footnotetext{
27 Disponivel em: http://www.preteitura.sp.gov.br; acesso em 18/03/2003.

20 O conceito de aglomerado urbano utilizado é o adotado pela Prefeitura de São Paulo: "é o território contíguo habitado com densidade residencial, desconsiderando-se os limites administrativos."
} 
unidades espaciais fundamentais da economia globalizada e atores políticos relevantes no cenário mundial (SCOTT, 1999). Isso se deve ao fato de que as atividades econômicas mais dinâmicas, intensivas em tecnologia, estão interconectadas em forma de redes densas. As redes estimulam a criatividade e a inovação, permitem a recombinação e a mudança nas empresas em rapidez compatível com a velocidade de alteração dos mercados e tecnologias, e facilitam as transações entre os atores de uma cidade-região e destes com o resto do mundo.

\subsubsection{A classificação da rede urbana brasileira e o processo de configuração das metrópoles no Brasil}

Ao tratar de proposições e políticas para o desenvolvimento nacional, é importante observar-se que o Brasil é um país eminentemente urbano, uma vez que $78 \%$ de sua população está nas cidades (Lacerda et al., 1998); cidades estas que podem ser classificadas, segundo estudo do IPEA/BGE/SEADE/UNICAMP (1999), em: metrópoles globais, metrópoles nacionais, metrópoles regionais, centros regionais e centros sub-regionais, formando um total de 111 centros urbanos, no país, que atuam como nós de uma intensa rede urbana. O estudo do IPEA/IBGE/SEADE/UNICAMP (1999) que estabelece a Nova Rede Urbana Nacional, aponta o Rio de Janeiro e São Paulo como as duas metrópoles globais do país, abrangendo 60 municípios e concentrando 17,3\% da população total do Brasil.

O processo de metropolização no Brasil iniciou-se nas décadas de 60 e 70 quando as grandes cidades, em sua maioria capitais de estados da federação, sofreram um significativo processo de crescimento relativo, principalmente, à expansão populacional e industrial, adicionando-se a isso a conurbação de núcleos urbanos periféricos à cidade central, caracterizando um modelo de organização espacial baseado na existência de um centro e uma periferia. São as seguintes as fases de metropolização características no Brasil (Lacerda et al., 1998):

- Décadas de 60/70 - início do processo, com a metrópole apresentando uma área central e uma periferia, estando esta última caracterizada por uma ocupação desordenada de áreas por migrantes de baixa renda, surgindo o fenômeno dos loteamentos 
clandestinos e das invasões, com severo comprometimento do meio ambiente da região e criando uma dualidade entre o "centro" (zona rica e próspera) e a "periferia" (zona pobre e com infra-estrutura deficiente);

- Décadas de 70/80 - período marcado pela substituição das antigas construções e estruturas por novas, caracterizando ampla verticalização de áreas residenciais que apresentavam melhores condições ambientais e de status; esta fase é caracterizada por uma forte especulação imobiliária e um empobrecimento das regiões centrais, provocado pela migração interna das populações. Nesta fase, agravam-se os problemas da periferia, pelo aumento da densidade de construções, deficiência nos serviços de infraestrutura, e o agravamento dos impactos sobre o meio ambiente decorrentes das ocupações desordenadas;

- Anos 90 - registram-se menores taxas de crescimento das grandes metrópoles, no que tange à expansão da população; verifica-se um considerável recuo no modelo centro/periferia, característico de períodos anteriores; o movimento de migração interna na metrópole cria áreas significativas de segregação marcadas por desigualdades na distribuição de renda e na oferta de bens e serviços públicos.

Obsenva-se, portanto, que as metrópoles brasileiras tornaram-se espaços com altos índices de fragmentação e desarticulação, como resultado de um rápido e desordenado processo de urbanização.

O processo de urbanização no Brasil é resultado direto das transformações econômicas observadas no país, nos últimos anos, principalmente relação aos efeitos da globalização, que impactam entre outros, o processo de migração interna e a estrutura do emprego urbano. De acordo com Motta (2001), esse processo apresenta como características, os seguintes aspectos:

- "Interiorização do fenômeno urbano;

- Acelerada urbanização das áreas de fronteira econômica;

- Crescimento das cidades médias;

- Periferização dos centros urbanos;

- Formação e consolidação de aglomerações urbanas de caráter metropolitano e não-metropolitano." (Motta, 2001). 
No Brasil, apenas São Paulo e Rio de Janeiro inserem-se e participam do fenômeno global. Voltando ao pensamento de Naisbitt citado anteriormente neste capítulo - "pense localmente, aja globalmente" - para não perder suas características e fatores diferenciais frente aos impactos gerados pela rede global (processo de "homogeinização"), faz-se necessária a valorização das características locais, com um intenso processo de geração de valor, de criação de cultura e de conhecimento.

E neste ponto, remete-se às diretrizes de descentralização política e administrativa que tem levado a uma revisão dos processos de planejamento urbano e a novas formas de participação da população (como os movimentos de gestão participativa já implantados em algumas prefeituras brasileiras) nos destinos de suas cidades, valorizando os aspectos culturais e ambientais do meio urbano.

\subsubsection{Caracterização das regiōes metropolitanas do Estado de São Paulo; os movimentos urbanos na Grande São Paulo}

O Estado de São Paulo possui três regiōes metropolitanas, a de São Paulo, a da Baixada Santista, e a região do entorno de Campinas. As três regiões metropolitanas paulistas atuam como uma rede integrada, com funções produtivas complementares, englobando também, nessa rede densa, as concentrações urbanas do Vale do Paraíba, de Sorocaba e de outras áreas, nesse perímetro. A Empresa Paulista de Planejamento Metropolitano S/A, vinculada à Secretaria de Economia e Planejamento do Estado de São Paulo atua diretamente na formulação de diretrizes, planos e programas dedicados ao desenvolvimento das metrópoles paulistas, e regiões do entorno e, neste sentido desenvolve estudos sobre essa rede metropolitana, denominada de Complexo Metropolitano Expandido (CME). O CME apresenta dados relevantes para os formuladores de políticas públicas: corresponde a um território de $42.737 \mathrm{~km}^{2}$ (17,18\% do território do Estado de São Paulo), concentra cerca de 26,3 milhões de habitantes, o que significa $71,13 \%$ da população estadual. Mais importante do que os dados relativos à densidade demográfica, essas regiões metropolitanas apresentam um Produto Interno Bruto (PIB) superior a alguns países europeus (como a Dinamarca e a Noruega), correspondendo, em 1997, a 223,8 bilhões de dólares $(78,6 \%$ do total do Estado de São Paulo e $27,8 \%$ do PIB nacional). 
Especificamente, as três regiões metropolitanas abrigam $58 \%$ da população do

Estado de São Paulo (21,4 milhões de habitantes), correspondendo a $13 \%$ da população total do País, e ocupam uma área de cerca de $14 \mathrm{mil} \mathrm{km}^{2}$. Na TAB. 3.14 são apresentados dados e comentários sobre as características das regiões metropolitanas de São Paulo (EMPLASA, 2003).

TABELA 3.14 - Características das Regiões Metropolitanas de São Paulo ${ }^{29}$

\begin{tabular}{|c|c|c|}
\hline Região Metropolitana & \begin{tabular}{|c|}
$N^{\circ}$ de \\
municípios
\end{tabular} & Comentários \\
\hline $\begin{array}{l}\text { São Paulo - Lei } \\
\text { Complementar } \\
\text { Federal } n^{0} 14, \text { de } \\
08 / 06 / 73 \text { e Lei } \\
\text { Complementar } \\
\text { Estadual } n^{\circ} 94 \text {, de } \\
29 / 05 / 74 .\end{array}$ & 39 & $\begin{array}{l}\text { Um em cada } 10 \text { brasileiros mora na Grande São Paulo, o que } \\
\text { significa dizer que o contingente populacional da região é } \\
\text { aproximada mente } 66 \% \text { superior ao da Região Metropolitana } \\
\text { do Rio de Janeiro, a segunda maior do país. A região é o } \\
\text { maior pólo de riqueza nacional, com um Produto Interno Bruto } \\
\text { (PIB) em torno de US } \$ 9,1 \text { bilhões (16,7\% do total nacional) } \\
\text { e renda per capita de US\$5 } 545 \text {. } \\
\text { "A Grande São Paulo detém a centralização do comando do } \\
\text { grande capital privado: aqui estão as sedes brasileiras dos } \\
\text { mais importantes complexos industriais, comerciais e } \\
\text { principalmente financeiros, que controlam as atividades } \\
\text { econômicas privadas. Esses fenômenos fizeram surgir e } \\
\text { condensar na Região Metropolitana uma série de serviços } \\
\text { sofisticados, definidos pela intima dependência da circulação } \\
\text { e transporte de informações: planejamento, publicidade, } \\
\text { marketing, finanças e consultorias, entre outros." }\end{array}$ \\
\hline $\begin{array}{l}\text { Baixada Santista - Lei } \\
\text { Complementar } n^{\circ} 815 \text {, } \\
\text { de } 30 / 07 / 96 \text {. }\end{array}$ & 9 & $\begin{array}{l}\text { Caracterizada por uma área litorânea, a região possui uma } \\
\text { população fixa de mais de } 1,4 \text { milhão de habitantes que, nos } \\
\text { períodos de férias e feriados, tem seu número duplicado. A } \\
\text { região é responsável por mais de um terço do comércio } \\
\text { exterior do país, por meio do porto de Santos, o maior } \\
\text { complexo da América do Sul (responsável por cerca de } 43 \% \\
\text { do movimento nacional de contêineres). A região conta ainda } \\
\text { com o parque industrial de Cubatão, importante pólo } \\
\text { siderúrgico nacional. Todo esse movimento industrial e } \\
\text { portuário, bem como as atividades comerciais, serviços e } \\
\text { turismo, são responsáveis pela geração de um PIB de US\$ } \\
7,4 \text { bilhões e renda per capita de US\$ } 5023 \text {. } \\
\text { O rápido crescimento de Santos, Cubatão e Guarujá, e a } \\
\text { impossibilidade de comportar as populações aderentes à } \\
\text { região, levou ao crescimento de outros municipios vizinhos } \\
\text { (São Vicente Praia Grande e Vicente de Carvalho) que } \\
\text { constituem, em grande parte, cidades dormitórios, } \\
\text { praticamente contínuos (conurbados). A região, em } \\
\text { decorrência dos mesmos fatores que a caracterizam como } \\
\text { expoente no processo de globalização, sofre com graves } \\
\text { problemas ambientais, de infra-estrutura, de transporte, de } \\
\text { habitação e de saneamento. }\end{array}$ \\
\hline $\begin{array}{l}\text { Campinas - Lei } \\
\text { Complementar } n^{\circ} 870 \text {, } \\
\text { de } 19 / 06 / 2000 .\end{array}$ & 19 & $\begin{array}{l}\text { Campinas é a mais nova região metropolitana do Estado. } \\
\text { Esta importante região ganhou, em } 10 \text { anos, cerca de meio } \\
\text { milhão de habitantes. Na região, encontra-se a maior } \\
\text { concentração de empresas de telecomunicações do pais; } \\
\text { outro dado importante é que um terço da carga aérea do } \\
\text { Brasil passa pela Região Metropolitana de Campinas. A }\end{array}$ \\
\hline
\end{tabular}

${ }^{29}$ Os dados inseridos nesta tabela estão disponíveis em: http://www.emplasa.sp.gov.br/metropoles/; acesso em 18/03/2003. 


\begin{tabular}{|l|c|l|}
\hline Região Metropolitana & $\begin{array}{c}\mathrm{N}^{\circ} \text { de } \\
\text { municípios }\end{array}$ & \multicolumn{1}{c}{ Comentários } \\
\hline & $\begin{array}{l}\text { região tem um PIB maior que o da Coréia do Sul e Suiça e } \\
\text { equivalente ao da Espanha. É um dos mais importantes pólos } \\
\text { de pesquisa científica e tecnológica do país. }\end{array}$ \\
\hline
\end{tabular}

Focalizando especificamente a área da Região Metropolitana de São Paulo, o Plano Metropolitano da Grande São Paulo veiculado pela EMPLASA, referente ao período de 1994/2010, propõe, entre suas diretrizes, aspectos que estão relacionados aos impactos da globalização na região. Na TAB. 3.15 encontram-se as diretrizes propostas pelo referido Plano, sob os aspectos de desenvolvimento urbano, estrutura urbana e circulação e transportes.

TABELA 3.15 - Plano Metropolitano da Grande São Paulo 1994/2010 - Diretrizes metropolitanas ${ }^{30}$

\begin{tabular}{|c|c|}
\hline $\begin{array}{c}\text { Desenvolvimento } \\
\text { urbano }\end{array}$ & $\begin{array}{l}\text { 1. Capacitar a Grande São Paulo (GPS) para o } \\
\text { desempenho eficaz de seu papel de principal metrópole } \\
\text { do País e integrante da rede mundial de pólos } \\
\text { econômico-direcionais; } \\
\text { 2. Consolidar as bases para que o desenvolvimento da } \\
\text { GSP seja sustentável tanto na dimensão físico-ambiental } \\
\text { como na perspectiva dos recursos humanos; } \\
\text { 3. Aprimorar o desempenho regional para assentamento } \\
\text { industrial; } \\
\text { 4. Consolidar, na GPS, perfil industrial sustentado nas } \\
\text { inovações tecnológicas em curso e adequação ao } \\
\text { ambiente metropolitano; } \\
\text { 5. Intensificar o processo de modernização da indústria da } \\
\text { GSP; } \\
\text { 6. Modernizar a infra-estrutura de apoio às atividades de } \\
\text { comércio exterior; } \\
\text { 7. Fortalecer, na GSP, a atividade terciária de apoio à } \\
\text { produção; } \\
\text { 8. Incentivar a geração de emprego e a melhoria no perfil } \\
\text { de distribuição da renda; } \\
\text { 9. Garantir condições para o desenvolvimento econômico } \\
\text { dos municípios situados total ou majoritariamente em } \\
\text { unidades de conservação ambiental; } \\
\text { 10. Contribuir para o re-ordenamento institucional nas } \\
\text { questões afeitas à organização territorial da Metrópole, } \\
\text { com vistas a reduzir as atuais dificuldades para o } \\
\text { desenvolvimento de atividades econômicas e a garantir } \\
\text { maior efetividade na preservação ambiental. }\end{array}$ \\
\hline Estrutura urbana & $\begin{array}{l}\text { 1. Promover a adoção de princípios de ordenamento do uso } \\
\text { e ocupação do solo, comuns para a GSP, que reduzam } \\
\text { as disparidades de tratamento do território metropolitano } \\
\text { e que favoreçam a observância de critérios técnicos no }\end{array}$ \\
\hline
\end{tabular}

${ }^{30}$ Informações que constam nesta tabela, adaptada, estão disponiveis em

http://www.emplasa.sp.gov.br/planos projetos/Diretrizes1.asp; acesso em 21/03/2003. 


\begin{tabular}{|c|c|}
\hline & $\begin{array}{l}\text { assentamento urbano; } \\
\text { 2. Promover maior eqüidade nas condições de localização } \\
\text { intra-urbanas na GSP, com ênfase para a } \\
\text { homogeinização da acessibilidade pelo sistema de } \\
\text { transporte público; } \\
\text { 3. Promover a expansão do centro metropolitano e a } \\
\text { consolidação de pólos sub-regionais e zonais de } \\
\text { comércio e serviços, que favoreçam a descentralização } \\
\text { do emprego terciário; } \\
\text { 4. Estimular a descentralização, em curso, das atividades } \\
\text { industriais de maior porte e impacto e propiciar seu } \\
\text { assentamento em áreas periféricas; } \\
\text { 5. Reconhecer e estimular o processo de renovação urbana } \\
\text { em curso, visando garantir a recuperação e/ou } \\
\text { preservação de padrões urbanos adequados às funções } \\
\text { metropolitanas; } \\
\text { 6. Ampliar o Cinturão Verde da Metrópole, proteger e } \\
\text { expandir o sistema de áreas verdes intra-urbanos; }\end{array}$ \\
\hline $\begin{array}{c}\text { Circulação e } \\
\text { transportes }\end{array}$ & $\begin{array}{l}\text { 1. Potencializar áreas retroportuárias e complementares às } \\
\text { funçōes dos três aeroportos metropolitanos, de forma a } \\
\text { acomodar as atividades de suporte aos mesmos e por } \\
\text { eles induzidas; } \\
\text { 2. Implantar melhorias e consolidar, em bases infra- } \\
\text { estruturais e de operação em alta qualidade técnica, o } \\
\text { sistema ferroviário de cargas e passageiros; } \\
\text { 3. Implantar novas ligações e trechos prioritários de } \\
\text { grandes projetos viários regionais; } \\
\text { 4. Executar melhorias e integrar à malha regional trecho de } \\
\text { vias existentes; } \\
\text { 5. Dar continuidade expandir as iniciativas de implantação } \\
\text { de terminais intermodais de carga geral e/ou } \\
\text { especializados, colocando-os à serviço dos troncos } \\
\text { rodoferroviários em áreas periféricas de maior } \\
\text { adensamento urbano; } \\
\text { 6. Implantar rede estrutural de transporte de passageiros de } \\
\text { média capacidade; } \\
\text { 7. Reforçar o processo de integração multimodal dos } \\
\text { sistemas para passageiro da GSP; } \\
\text { 8. Desenvolver programa de melhoramento de operação e } \\
\text { segurança de tráfego nos pontos críticos da malha } \\
\text { regional onde haja ocorrência freqüente de acidentes e } \\
\text { congestionamentos; } \\
\text { 9. Criar base técnica adequada para a melhoria operacional } \\
\text { e de segurança no tráfego. }\end{array}$ \\
\hline
\end{tabular}

O perfil populacional e econômico da região metropolitana de São Paulo impacta, consideravelmente, o Estado de São Paulo e o país. Observe-se também que, nos últimos anos, houve mudanças significativas no perfil econômico dessa região. Segundo Masano (2001),..."Há 15 anos, para cada emprego na indústria havia um no setor de serviços; hoje, para cada emprego na indústria há mais de três no setor de serviços. Além disso, resultado da 
globalização da região, continua o autor, ..."estão sendo observados números recorde de fusões e aquisições, em 2001, sendo mais de $60 \%$ das negociações envolvendo o capital estrangeiro".

$\mathrm{Na}$ TAB. 3.16, analisando dados disponibilizados na edição de 2001 de Melhores e Maiores da revista Exame, Masano (2001) apresenta um levantamento comparativo da evolução, na última década, do número e do faturamento de empresas sediadas na Grande São Paulo, que estão na lista das 500 maiores empresas privadas listadas no anuário da revista Exame.

TABELA 3.16 - Comparativo da evolução do número e do faturamento de empresas sediadas na Grande São Paulo, na última década. (Masano, 2001, adaptado)

\begin{tabular}{|c|c|c|c|c|}
\hline $\begin{array}{l}\text { Evolução do } \\
\text { número de } \\
\text { empresas }\end{array}$ & Origem & Brasileira & Origem & Estrangeira \\
\hline & 1999 & 2000 & 1999 & 2000 \\
\hline Grande São Paulo & 141 & $\overline{76}$ & 89 & 130 \\
\hline Brasil & 353 & 269 & 147 & 231 \\
\hline $\begin{array}{l}\text { Evolução em } \\
\text { Faturamento e } \\
\text { vendas } \\
\text { (US\$ bilhões) }\end{array}$ & : & & . & \\
\hline Grande São Paulo & 32,4 & 37,7 & 35,6 & $\overline{91,3}$ \\
\hline Brasil & 83,9 & 124,3 & 60 & $\overline{158,7}$ \\
\hline
\end{tabular}

Há um acentuado aumento do número de empresas com capital de origem estrangeira instaladas na grande São Paulo, o que corrobora as características de megacidade global, ou seja, a região metropolitana de São Paulo está sendo considerada, internacionalmente, uma área de interesse para investimentos e tecnologia por grandes corporações.

Reforçando essa visão, pode-se citar análise realizada pela equipe coordenada pela pesquisadora Sueli Schiffer que desenvolveu um Projeto Temático, no âmbito da Fundação de Amparo à Pesquisa do Estado de São Paulo - FAPESP, intitulado "Os impactos da globalização sobre São Paulo" (Schiffer, 1997). A análise realizada pelos pesquisadores permitiu confirmar porque São Paulo está incluída no rol das cidades globais. Para o mencionado estudo, os pesquisadores utilizaram os parâmetros propostos por uma pesquisa semelhante realizada na Universidade de Columbia, nos Estados Unidos, sobre cidades globalizadas, líderes, a saber: Nova lorque, Londres e Tóquio. Entre as características das cidades globais encontram-se: 
“...a centralização do controle de capital, o crescimento acelerado do setor de serviços (incluindo financeiro) em detrimento do setor secundário, um processo de desindustrialização acelerado, o crescimento do desemprego para trabalhadores não qualificados, o crescimento do setor informal de trabalho e a maior valorização das áreas imobiliárias onde se instalam atividades e empresas inseridas no processo de globalização". (Schiffer, 1997)

Os pesquisadores classificam, portanto, São Paulo como uma cidade global, pois participa de uma rede de cidades, atuando como um dos nós, nas transações comerciais e financeiras globalizadas, porém, ao contrário de Nova lorque, Londres e Tóquio, por exemplo, não atua como líder, mas sim como nó auxiliar no processo de globalização. Segundo Schiffer (1997):

"Esta cidade funciona como um centro regional de decisões no processo econômico mundial...Em São Paulo podem ser tomadas as decisões sobre o capital relativas ao Mercosul, à América do Sul e mesmo à América Latina."

Os efeitos desse processo podem ser observados com as transformações na ocupação dos espaços na cidade. Em um estudo sobre as mudanças na ocupação dos espaços urbanos em São Paulo, publicado na FOLHA DE SÃO PAULO (2001) observa-se que grandes corporações, principalmente dos setores de tecnologia e farmacêutico, estão visualizando as oportunidades que se apresentam e têm sido protagonistas dessa nova ocupação.

O referido estudo analisa a ocupação de antigos galpões industriais de São Paulo por centros empresariais, áreas residenciais e de lazer (FOLHA DE SÃO PAULO, 2001), revelando que $19,1 \%$ de todos os espaços industriais na cidade já são ocupados por empresas da área de serviços e não do ramo industrial. Na FIG. 3.5, são mostradas as novas tendências de ocupação de antigas áreas industriais de São Paulo.

De acordo com esse estudo, são as seguintes as regiões afetadas por esse movimento e respectivas novas características de ocupação:

- Região da Barra Funda, Lapa e Vila Leopoldina - tendência de concentração de escritórios de alto padrão na Barra Funda; na Vila Leopoldina, instalações de residências e atividades comerciais;

- Região da Avenida do Estado, Belém, Mooca e Tatuapé - tendência de surgimento de área residenciais de todos os padrões, principalmente no Brás e na Mooca; 
- Região da Zonal Sul (Santo Amaro, marginal Pinheiro e Jurubatuba)

- tendência de ocupação por prédios comerciais de escritórios ou de eventos, principalmente na marginal Pinheiros;

- Região Sudoeste - Itaim e Vila Olímpia - concentração de escritórios de tecnologia na área próxima à marginal Pinheiros e no Itaim; nas outras áreas a tendência é de ocupação com flats e residenciais de alto padrão;

- Região do $A B C$ - apresenta indústrias ainda ativas com tendência de saída para outras regiões do país.

Outro movimento interessante apontado pelo estudo diz respeito à ocupação de espaços disponíveis de galpões ao longo das principais vias de acesso ao município de São Paulo (Anhanguera, Castelo Branco, Régis Bittencourt, Anchieta-Imigrantes, Dutra e Fernão Dias). Este movimento tem sido protagonizado por empresas das áreas de logística e distribuição.

Para concluir este item, urbanistas tais como Jorge Wilheim e Raquel Rolnik apontam para o futuro de São Paulo como uma metrópole caracterizada pela descentralização, como forma de superar os problemas e dificuldades atuais. Esta descentralização seria caracterizada pelo desenvolvimento de pólos (centros) nos bairros que contenham uma mistura de atividades, que possam atender a interesses de diversos grupos. Também levantam a necessidade de estabelecimento de uma nova política para o uso e ocupação do solo, um novo zoneamento e para uma requalificação dos espaços do centro expandido da cidade.

\subsection{4 - As regiōes vizinhas à Cidade Universitária - características gerais e perspectivas}

A zona sudoeste, onde se encontra a Cidade Universitária, tem características peculiares, devido à elevada densidade de instituições ligadas ao sistema local de inovação.

Utilizando os modelos ternários usualmente considerados como metáforas de sistemas de inovação, seja o clássico Triângulo de Sábato ou a Triple Helix, verifica-se que os três tipos de atores institucionais têm representantes de excelência nesse espaço. A infra-estrutura científicotecnológica inclui cerca de 5.000 pesquisadores, além de estudantes e profissionais baseados no campus da capital da Universidade de São Paulo - 
USP, no Instituto de Pesquisas Energéticas e Nucleares - IPEN, no Instituto de Pesquisas Tecnológicas - IPT (parceiros no CIETEC - Centro Incubador de Empresas Tecnológicas), no Instituto Butantã, entre outras instituições. A principal agência de financiamento à Ciência e Tecnologia do Estado - a FAPESP, encontra-se próxima à Cidade Universitária. Na TAB. 3.17 apresenta-se alguns dados que validam a visão de excelência da infra-estrutura científico-tecnológica do Estado de São Paulo, veiculadas em estudo realizado pela FAPESP Indicadores de Ciência, Tecnologia e Inovação do Estado de São Paulo (Landi, 2001).

A mudança do perfil econômico no entorno da Cidade Universitária gera uma necessidade e uma oportunidade. Devido à falência ou saída de várias indústrias e empresas tradicionais, esta microrregião vem passando por uma fase de diminuição da atividade econômica local, verificando-se, em decorrência, uma redução no movimento comercial e de serviços, que contribuem para a queda do nível e da qualidade do emprego. Observa-se, portanto, a necessidade (e a oportunidade) de incentivar a criação de empreendimentos que alterem e inovem a vocação econômica da região.

Problemas análogos àqueles enfrentados na zona sudoeste da Região Metropolitana da Grande São Paulo ocorrem em outras regiōes fortemente adensadas - tanto no Estado de São Paulo (na Baixada Santista e na já prevista região metropolitana de Campinas), como em outros estados do País e, ainda, em outras metrópoles da América Latina (Cidade do México, Buenos Aires, Bogotá, Caracas e Lima). Assim, a revitalização de áreas, permitindo aumento de oportunidades de emprego qualificado, incremento da competitividade de empresas, estabelecimento de empreendimentos da economia do conhecimento capazes de sustentar a atividade econômica é uma questão de grande importância para os formuladores de políticas públicas. 


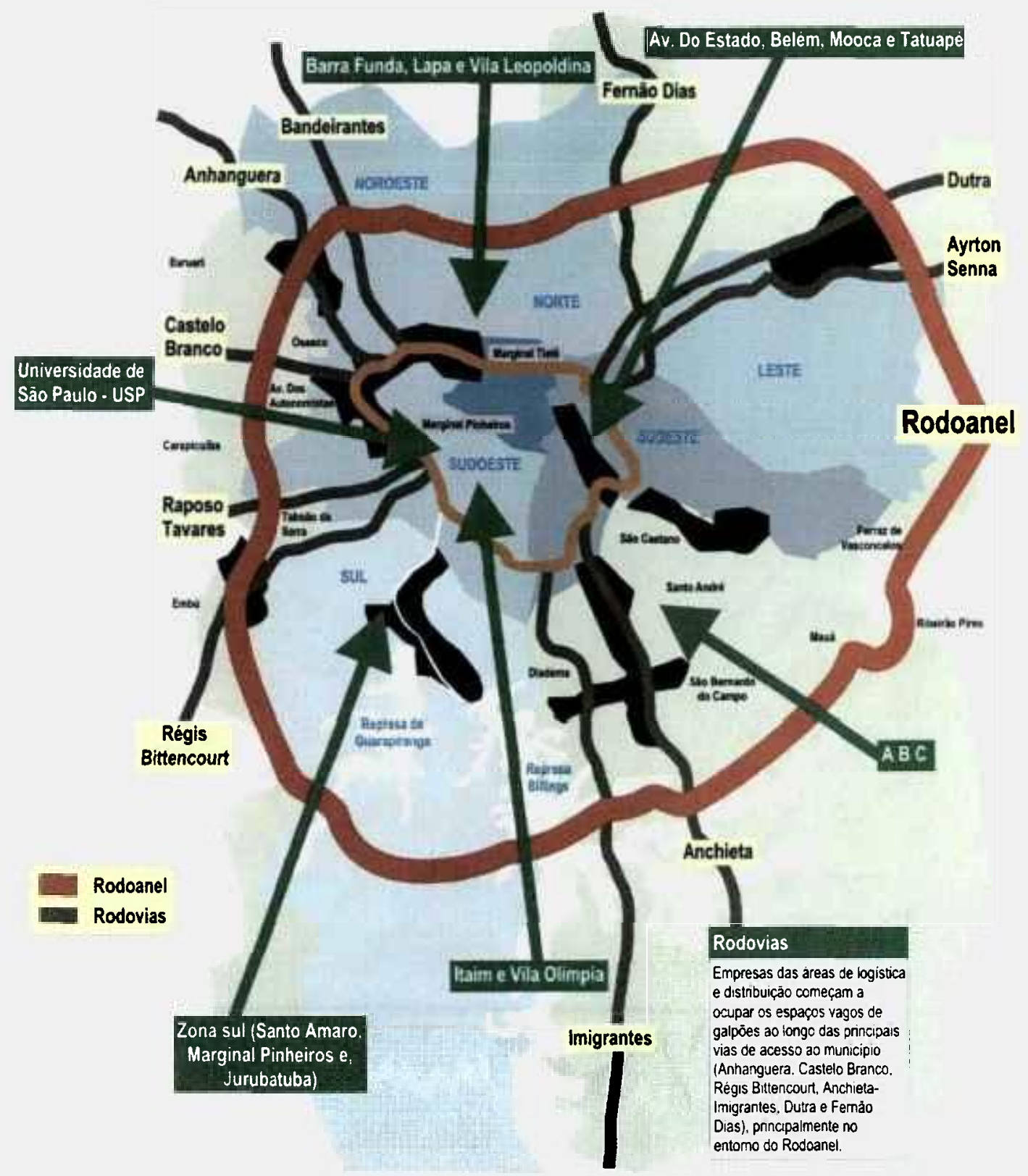

FIGURA 3.5: Novas tendências de ocupação na cidade de São Paulo (FOLHA DE SÃO PAULO, 2001, adaptada para inclusão da região da Cidade Universitária)

TABELA 3.17 - Principais dados/indicadores da infra-estrutura científicotecnológica de São Paulo (Landi, 2001)

Cerca de $70 \%$ da produção científica indexada nas bases do ISI (Institute for Scientific Information, Filadélfia, EUA), originou-se em instituiçöes localizadas no Sudeste.

$O$ perfil de publicaçōes indexadas nas bases do ISI em relação à presença de líderes de pesquisa por estados brasileiros, os números indicam que São Paulo, Rio de Janeiro e Minas Gerais produziram $75 \%$ das publicações indexadas (dados do Diretório dos Grupos de Pesquisa do CNPq).

Dados do Diretório dos Grupos de Pesquisa do CNPq (1997) revelam que os cientistas doutores do Estado de São Paulo correspondem a $41,2 \%$ em relação ao total do Brasil (Dados colhidos e adaptados da publicação "Indicadores C\&T e Inovação do Estado de São Paulo - FAPESP (LANDI, 2001)

Avaliação dos cursos de Pós-Graduaçāo Estado de São Paulo e Brasil (1998) - com base nos dados do MEC/Capes (Brasília/DAV-1999) (adaptado da Tab. 3.27 Indicadores C\&T e Inovação do Estado de SP (LANDI, 2001) 
Mestrado/doutorado (notas de avaliação)

\begin{tabular}{|c|c|c|c|c|c|c|c|c|}
\hline \multicolumn{9}{|c|}{ Mestrado/doutorado (notas de avaliação) } \\
\hline 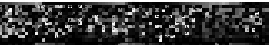 & 7 & 6 & 5 & 4 & 3 & 2 & 1 & GHOHSA \\
\hline São Paulo & 14 & 40 & 139 & 160 & 101 & 8 & 5 & 3 \\
\hline Brasil & 22 & 102 & 287 & 445 & 401 & 46 & 12 & 4 \\
\hline$\%$ SP/Brasil & 63,6 & 39,2 & $\overline{48,4}$ & 36,0 & 25,2 & 17,4 & 41,7 & 75,0 \\
\hline
\end{tabular}

CN-curso novo; CR-curso em reestruturação; AS-sem avaliação

Obs: as notas 7 e 6 säo reservadas somente para programas que contam com doutorado com nível de excelência.

O sistema acadêmico estadual paulista foi capaz de formar e fixar um grande número de pesquisadores, percentual expressivo se comparado às demais regiōes do país.

Pesquigesdores aliwos no segmento academico por dependencia administrativa ( $\%$ )

\begin{tabular}{|l|c|c|c|c|}
\hline $\begin{array}{l}\text { Dependência } \\
\text { Administrativa }\end{array}$ & São Paulo & Sudeste & Outras regiōes & Brasil \\
\hline Federal & 9,7 & 35,8 & 86,9 & 53,0 \\
\hline Estadual & 82,4 & 55,3 & 6,2 & 38,8 \\
\hline Municipal & 0,2 & 0,2 & 0,3 & 0,2 \\
\hline Particular & 7,7 & 8,7 & 6,6 & 8,0 \\
\hline Total & 100 & 100 & 100 & 100 \\
\hline
\end{tabular}

ladaptado da Tab. 4.3 Indicadores C\&T e lnovação do Estado de SP(2001).

Considerando-se os depósitos de patentes, modelos de utilidade e desenho industrial como indicadores de inovação, a tabela abaixo expõe as patentes concedidas por modalidade e origem do depositante (adaptado da Tab. 7.16 Indicadores C\&T e Inovação do Estado de SP(LANDI, 2001) fonte: (NPI):

\begin{tabular}{|c|c|c|c|c|c|c|c|c|c|c|}
\hline Modalidade/origem & 1989 & 1990 & 1991 & 1992 & 1993 & 1984 & 1995 & 1996 & 1997 & 1998 \\
\hline \multicolumn{11}{|l|}{$\begin{array}{l}\text { Patentes de } \\
\text { invencāo }\end{array}$} \\
\hline São Paulo & 279 & 271 & 211 & 151 & 212 & 233 & 280 & 90 & 119 & 223 \\
\hline Brasil & 474 & 453 & 341 & 254 & 378 & 419 & 525 & 189 & 232 & 406 \\
\hline$\%$ SP/BR & 58,9 & 59,8 & 61,9 & 59,4 & 56,1 & 55,6 & 53,3 & 47,6 & 51,3 & 54,9 \\
\hline \multicolumn{11}{|l|}{ Modelo de Utilidade } \\
\hline São Paulo & 328 & 331 & $2 \sqrt{3}$ & 177 & 211 & 352 & 325 & 120 & 183 & 245 \\
\hline Brasil & 506 & 484 & 311 & 253 & 297 & 508 & 484 & 192 & 299 & 385 \\
\hline$\%$ SP/BR & 64,8 & 68,4 & 70,1 & 70,0 & 71,0 & 69,3 & 67,1 & 62,5 & 61,2 & 63,6 \\
\hline \multicolumn{11}{|l|}{ Desenho Industrial } \\
\hline São Paulo & 445 & 346 & 290 & 204 & 225 & 273 & 347 & 413 & 630 & 1308 \\
\hline Brasil & 627 & 598 & 471 & 353 & 364 & 461 & 454 & 557 & 841 & 1722 \\
\hline$\%$ SP/BR & 71,0 & 57,9 & 61,6 & 57,8 & 61,8 & 59,2 & 76,4 & 74,1 & 74,9 & 75,9 \\
\hline \multicolumn{11}{|l|}{ Total } \\
\hline São Paulo & 1052 & 948 & 719 & 532 & 648 & 858 & 952 & 623 & 932 & 1776 \\
\hline Brasil & 1607 & 1535 & 1123 & 860 & 1039 & 1388 & 1463 & 938 & 1372 & 2513 \\
\hline$\% \mathrm{SP} / \mathrm{BA}$ & 65,5 & 61,8 & 64,0 & 61,9 & 62,4 & 61,8 & 65,1 & 66,4 & 67,9 & 70,7 \\
\hline
\end{tabular}

Em 1998, São Paulo contribuiu com $70,7 \%$ do total de depósito de patentes, modelos de utilidades e desenho industrial, somados, em relaçāo ao país.

Os dados comparativos sobre os recursos humanos de pesquisa revelam que na época desses estudos, dos cerca de $\mathbf{4 6 . 0 0 0}$ pesquisadores ativos na área de governo no Brasil, o Estado de São Paulo concentrava aproximadamente $35 \%$ dos pesquisadores do setor público.

\begin{tabular}{|c|c|c|c|c|c|}
\hline (1) & $\begin{array}{l}\text { Total } \\
\text { Pesquisadores } \\
\text { (a) }\end{array}$ & $\begin{array}{l}\text { Pesquisadores/ } \\
\text { PEA(") }\end{array}$ & $\begin{array}{l}\text { Pesquisadores } \\
\text { Governo (b) }\end{array}$ & $\begin{array}{c}\text { (b) } /(a) \\
\%\end{array}$ & $\begin{array}{l}\text { Pesquisadores/ } \\
\text { Mil habltantes } \\
\text { São Paulo }\end{array}$ \\
\hline Brasil & 49.702 & 6,7 & 45.843 & 92,2 & fow \\
\hline Argentina & 21.821 & $\overline{15,0}$ & 18.092 & 82,9 & 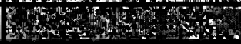 \\
\hline México & 19.434 & 5,5 & 17.428 & 89,7 & 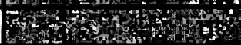 \\
\hline $\begin{array}{c}\text { São Paulo } \\
\text { (1999) }\end{array}$ & & & 15.961 & & 0,45 \\
\hline
\end{tabular}

(*)PEA: população economicamente ativa

(adaptado da Tabela 4.1 mais dados Indicadores C\&T e Inovaçāo do Estado de SP (LANDI, 2001) fonte: OCDE-STEPI-RICYT

Dispêndios com a atividade de P\&D:

$\checkmark \quad$ os gastos médios com P\&D no Estado de São Paulo entre 1995 e 1998 corresponderam a US\$ 2,5 bilhões ao ano, equivalendo, na média, a 0,98\% do PIB paulista;

$\checkmark \quad$ a média de gastos com P\&D no Estado de São Paulo corresponderam a cerca de $38 \%$ do total nacional;

$\checkmark$ a tabela abaixo (adaptado da Tabela 5.3 Indicadores C\&T e inovacão do Estado de SP(LANDI, 
2001)), o dispêndio estadual em P\&D, em percentual, por fonte de recursos, no período de 1995-1998:

\begin{tabular}{|c|c|c|c|c|c|}
\hline Fonte de Recursos & 1995 & 1996 & 1997 & 1998 & $1995-1998$ \\
\hline Governo federal & $31,3 \%$ & $29,4 \%$ & $27,8 \%$ & $26,0 \%$ & $-12,0 \%$ \\
\hline Governo estadual & $37,7 \%$ & $34,4 \%$ & $31,5 \%$ & $35,5 \%$ & $-0,3 \%$ \\
\hline $\begin{array}{c}\text { Empresas } \\
\text { industriais }\end{array}$ & $31,0 \%$ & $36,2 \%$ & $40,7 \%$ & $38,5 \%$ & $31,1 \%$ \\
\hline
\end{tabular}

Observe-se que houve uma significativa redução dos recursos aplicados pelo governo federal e que a aplicação referente ao governo estadual manteve-se estável. É importante ressaltar, no interesse deste estudo, que os dispêndios com P\&D no setor empresarial tiveram uma substancial elevação.

Novas estruturas político-administrativas e a aprovação do Plano Diretor para a cidade de São Paulo, trazem importantes e estratégicas mudanças no planejamento da cidade. O Plano Diretor aprovado na Câmara Municipal contribui para estabelecer a visão, as diretrizes e as previsões que nortearão por dez anos as ações da administração pública, dos agentes econômicos $e$ da sociedade em geral. Segundo 0 arquiteto e urbanista Jorge Wilheim ${ }^{31}$, o plano proposto e amplamente discutido com a sociedade envolve conceitos inovadores de planejamento urbano, prevendo entre outros aspectos:

- a já comentada necessidade de desconcentração da cidade, com previsão de expandir, de forma planejada, em áreas urbanas menos congestionadas, por meio de operações urbanas nas regiões de: Vila Sônia, Vila Leopoldina, Jacu-Pêssego, Celso Garcia e Penha, Carandiru e Vila Maria;

- O Plano evidencia a existência de uma diagonal de oportunidades cruzando a cidade, das divisas com São Caetano e Santo André, passando por Ipiranga, Mooca, Cambuci, Brás e Pari, até o Centro, e prosseguindo pela Barra Funda, Água Branca, Lapa, Pirituba e Perus (estão previstas duas operações urbanas apoiadas por transportes de massa, com vista a reocupar áreas ociosas, revitalizando-as com moradias e atividades que as aproximem do centro - aqui também contemplando o que já foi discutido por outros urbanistas, referente à necessidade de revitalizar a moradia na direção do centro);

- O Plano dá significativa ênfase ao aspecto ambiental da cidade, prevendo cerca de vinte novos parques e parques lineares de fundos de vale de córregos não canalizados, drenagem de áreas em http://www.fortalsampa.hpg.ig.com.br/pdnews001.htm; acesso em 23/03/2003. 
impermeabilizadas ("piscinões", áreas de drenagem natural e "piscininhas");

- O Plano prevê completa reformulação do sistema viário da cidade;

- O Plano estabelece um novo sistema para regulação do uso do solo e contem a expansão de bairros já congestionados.

Sob os aspectos políticos e sociais, são previstas ações para estimular a ampla participação da sociedade, confirmando uma tendência, por meio da criação do Conselho de Política Urbana.

Outra ação política que impactou a administração pública da cidade foi a aprovação da Lei das Subprefeituras e a criação da Secretaria Municipal das Subprefeituras. Nela as antigas Administrações Regionais passam a atuar como Subprefeituras, tendo estes órgãos maior autonomia de ação e orçamentária. A cidade está dividida em 31 subprefeituras, sendo que para o interesse desta pesquisa, caracterizam-se três subprefeituras que são responsáveis por áreas adjacentes ao campus da Cidade Universitária: Butantã, Lapa e Pinheiros. Nessas áreas, assim como nas outras subprefeituras da cidade, está sendo conduzida uma ampla discussão com as comunidades locais a respeito das propostas para o desenvolvimento do Plano Diretor Estratégico nas Subprefeituras. Na TAB. 3.18 encontram-se as características das três Subprefeituras mencionadas.

Observa-se, principalmente nas Subprefeituras do Butantã e da Lapa, áreas de antigos galpões industriais vazios, áreas degradadas e zonas de favelas em contraste com regiões residenciais e comerciais de alto nivel e sofisticação. Pode-se citar como exemplo a Vila Leopoldina, inserida na Subprefeitura da Lapa, onde este quadro é bem característico. Situações como essas consistem em desafios que estão sendo considerados nas chamadas "Operações Urbanas". As Operações Urbanas Consorciadas consistem em um conjunto de intervenções e medidas coordenadas pelo Poder Público Municipal, com a participação dos proprietários, moradores, usuários permanentes e investidores privados, com o objetivo de alcançar em área específica, transformações urbanísticas estruturais, melhorias sociais, valorização ambiental, ampliação e qualificação dos espaços públicos.

Essas áreas estão sendo consideradas para o desenvolvimento e implantação de empreendimentos por parte de empresários do mercado 
imobiliário, já considerando as oportunidades geradas pelas operações urbanas, resultado de estreita colaboração entre comunidades, poder público e iniciativa privada.

Concluindo este item, comenta-se, portanto, a oportunidade de implantação de iniciativas como parques tecnológicos, entre outras, principalmente nas regiões das Subprefeituras de Butantã e Lapa, próximas à Cidade Universitária, que contenham em seus projetos, como características primordiais para sua plena inserção na vida das regiões, conceitos adequados (com uso misto) que possam contribuir para o desenvolvimento e melhoria da qualidade de vida em suas áreas adjacentes, bem como estejam de acordo com os requisitos das operações urbanas planejadas para a região.

TABELA 3.18 - Características das Subprefeituras que envolvem a Cidade Universitária $^{32}$

\begin{tabular}{|l|l|c|}
\hline Subprefeitura & \multicolumn{1}{|c|}{ Características } & \multicolumn{1}{|c|}{ Distritos } \\
\hline Butantã & $\begin{array}{l}\text { Área: } 56,1 \mathrm{~km}^{2} \\
\text { População: } 375.943 \\
\text { habitantes } \\
\text { Por esta região do municipio de São } \\
\text { Paulo passam importantes eixos } \\
\text { rodoviários que fazem a ligação } \\
\text { norte-sul do país, além da ligação } \\
\text { entre a cidade e o interior sul e oeste } \\
\text { do Estado de São Paulo. Também } \\
\text { nesta região encontra-se a Cidade } \\
\text { Universitária (Universidade de São } \\
\text { Paulo), local onde estão também } \\
\text { localizados três dos maiores } \\
\text { institutos de pesquisas científicas e } \\
\text { tecnológicas do país: IPEN, IPT e } \\
\text { Instituto Butantan. }\end{array}$ \\
\hline
\end{tabular}

${ }^{32}$ Dados sobre as subprefeituras disponiveis em http://www.prefeitura.sp.org.br; acesso em 23/03/2003. 


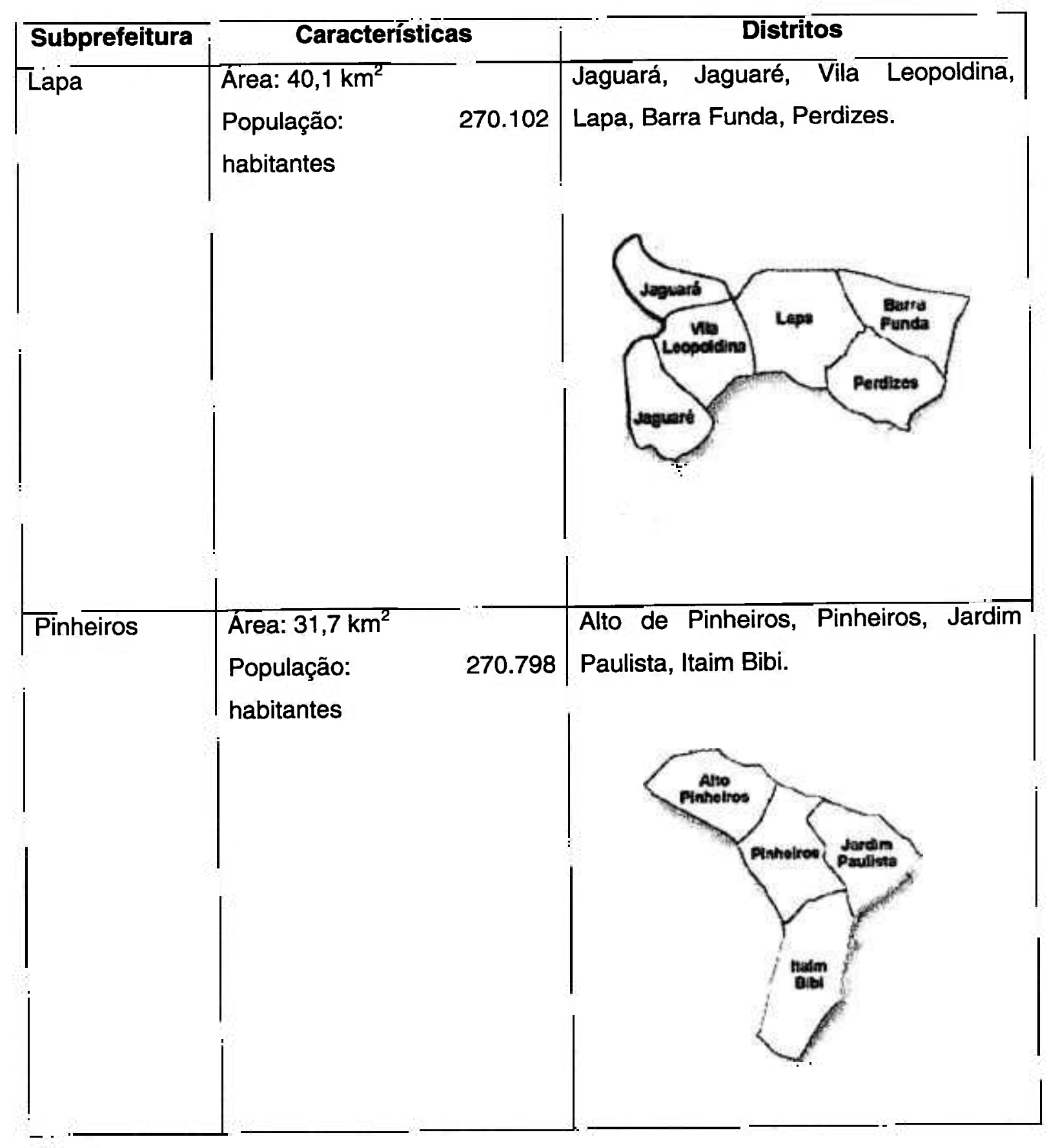




\section{METODOLOGIA DA PESQUISA}

"Um cientista, seja teórico ou experimental, formula enunciados ou sistemas de enunciados e verifica-os um a um. No campo das ciências empíricas, para particularizar, ele formula hipóteses ou sistemas de teorias, e submete-os a teste, confrontando-os com a experiência, através de recursos de observação e experimentação. $A$ tarefa da lógica da pesquisa científica, ou da lógica do conhecimento é, segundo penso, proporcionar uma análise lógica desse procedimento, ou seja, analisar o método das ciências empiricas."

(Karl Raimund Popper) ${ }^{1}$

Neste capítulo são apresentados os aspectos relacionados à metodologia utilizada, introduzindo os tópicos relativos aos objetivos, métodos e instrumentos de pesquisa. Esta pesquisa apresenta aspectos de caráter exploratório, principalmente devido à inovação do tema (parques tecnológicos urbanos) e ao reduzido conjunto de informações existentes no país. Com relação ao envolvimento do pesquisador, a pesquisa se caracteriza na concepção de pesquisa-ação, conforme será visto no transcorrer deste capítulo.

\subsection{Método da pesquisa}

Tendo em vista o objeto deste trabalho, conforme descrito nos capítulos 1 e 2, é importante, na abertura deste item, estabelecer a relação entre a metodologia científica e sua utilização para estudar os fenômenos sociais. Gil (1999) define bem essa relação:

"Pode-se...definir pesquisa social como o processo que, utilizando a metodologia científica, permite a obtenção de novos conhecimentos no campo da realidade social. ${ }^{2}$

Partindo, portanto, dessa correlação, passa-se a discutir e apresentar a metodologia aplicada à presente pesquisa.

\footnotetext{
${ }^{1}$ Texto extraído da obra "A Lógica da Pesquisa Científica", tradução do original "The Logic of Scientific Discovery", $2^{a}$ edição, Editora Cultrix Ltda., 1974, p.27.

${ }^{2}$ Para Gil(1999) "Realidade social é entendida aqui em sentido bastante amplo, envolvendo todos os aspectos relativos ao homem e seus múltiplos relacionamentos com outros homens e instituições sociais".
} 


\subsubsection{Bases lógicas da pesquisa}

$\mathrm{Na}$ TAB. 4.1 é apresentada a aplicação do método científico, bem como a correlação com as etapas da pesquisa social, para o planejamento e execução das atividades desenvolvidas neste trabalho.

O "método hipotético-dedutivo" (ou "método dedutivo de prova"), desenvolvido por Popper (1974), contrário ao raciocínio indutivo, é o adotado no desenvolvimento da metodologia do presente trabalho. 0 método inicia-se pela observação de uma lacuna no conhecimento científico surgindo, portanto, o problema. Para tentar resolver ou explicar as dificuldades do problema identificado, são formuladas hipóteses ou conjecturas, passando-se por um processo de inferência dedutiva (dedução de conseqüências observadas). Em seguida, é desenvolvida uma fase de "tentativa de falseamento" onde evidências empíricas possam falsear a hipótese formulada. A fase final é a de corroboração, ou seja, quando não se consegue mais falsear a hipótese, esta se mostra válida, pois superou todos os testes.

No que se refere à metodologia adotada sob o prisma da pesquisa social, na TAB. 4.1, na coluna de "etapas da pesquisa social", encontram-se embutidas as três fases previstas nos processos clássicos de pesquisa social, a saber: planejamento, coleta de dados, análise e interpretação e redação final do relatório da pesquisa. No caso deste estudo, são consideradas as etapas propostas por Gil (1999), acrescidas de uma fase de elaboração da proposta para - Parque Tecnológico de São Paulo, a partir das observações e resultados obtidos na pesquisa de campo.

\subsubsection{Complementação do paradigma hipotético-dedutivo com o paradigma holístico-interpretativo}

A partir dos estudos exploratórios realizados, tendo em vista o tema de pesquisa proposto, além dos modelos clássicos de pesquisa empirica, constatouse ser necessária a abordagem de elementos subjetivos, de forma a buscar maior proximidade com a realidade do que simplesmente basear-se em fatos. Neste sentido, no presente estudo, adota-se a pesquisa qualitativa, e seus métodos associados em complementação ao paradigma hipotético-dedutivo abordado no item anterior. Neste sentido, em complementação à abordagem positivista e à testabilidade do modelo proposto, encontra-se a abordagem interpretativa da realidade obsenvada. De acordo com Myers (2002), os métodos qualitativos 
caracterizam-se pela imersão do pesquisador no contexto e na perspectiva interpretativa da pesquisa. Entre os métodos qualitativos mais usados encontramse: a pesquisa-ação, estudos de caso e estudos etnográficos. $\mathrm{Na}$ presente pesquisa, tendo em vista o fator inovativo do tema, principalmente se considerarmos o território nacional, o relacionamento, na fase de pesquisa de campo, entre o pesquisador e o pesquisado não ocorre tão somente como um processo de observação das práticas, mas sim, há uma identificação entre ambos (modo cooperativo-participativo)- participação ativa na análise e interpretação dos dados. De acordo com Thiollent (2002),

"...a idéia de pesquisa-ação encontra um contexto favorável quando os pesquisadores não querem limitar suas investigaçōes aos aspectos acadêmicos e burocráticos da maioria das pesquisas convencionais. Querem pesquisas nas quais as pessoas implicadas tenham algo a "dizer"e a "fazer". Não se trata de simples levantamento de dados ou de relatórios a serem arquivados. Com a pesquisa-ação os pesquisadores pretendem desempenhar um papel ativo na própria realidade dos fatos observados."

Ainda segundo Thiollent (2002), a pesquisa-ação é uma estratégia metodológica da pesquisa social caracterizando-se por:

- "há uma ampla e explícita interação entre pesquisadores e pessoas implicadas na situação investigada;

- desta interação resulta a ordem de prioridade dos problemas a serem pesquisados e das soluções a serem encaminhadas sob forma de ação concreta;

- o objeto de investigação não é constituído pelas pessoas e sim pela situação social e pelos problemas de diferentes naturezas encontrados nesta situação;

- o objetivo da pesquisa-acão consiste em resolver ou, pelo menos, em esclarecer os problemas da situação observada;

- há, durante o processo, um acompanhamento das decisões, das ações e de toda a atividade intencional dos atores da situação;

- a pesquisa não se limita a uma forma de ação (risco de ativismo); pretende-se aumentar o conhecimento dos pesquisadores $e$ o conhecimento ou o "nivel de consciência" das pessoas e grupos considerados."

Caracteriza-se, portanto, a presente pesquisa na concepção de pesquisa-ação. 


\section{2 $O$ instrumento de pesquisa}

Para o desenvolvimento do instrumento de pesquisa aplicado às experiências selecionadas, foram definidas as dimensões analisadas na pesquisa de campo. São nove as dimensões propostas (vide FIG. 4.1), a saber:

- Aspectos relacionados à localização: plano estrutural, impacto ambiental, arquitetura, intra-estrutura e serviços;

- O contexto sócio-econômico, político e cultural da região: informações demográficas e econômicas da região; estratégias e políticas e desenvolvimento regional; barreiras culturais;

- Legislação de apoio;

- Missão, metas e estrutura do modelo adotado;

- Aspectos relacionados ao gerenciamento: modelo de gestão; processos de seleção; programas de parceria e participação em redes; proteção à propriedade intelectual;

- Aspectos financeiros e incentivos ao investimento: orçamento e custo operacional; estratégias de auto-sustentação; aproximação com agentes de capital inicial e capital de risco;

- Marketing e comunicação: ações de sensibilização, assessoria de marketing para as empresas;

- Aspectos relacionados à formação e treinamento: treinamento para o empreendedorismo e para gestão de negócios;

- Resultados obtidos e avaliação de impacto na região.

Com base nas dimensões definidas, foi desenvolvido o questionário, apresentado no APÉNDICE A, que foi elaborado em três versões: português, espanhol e inglês. 


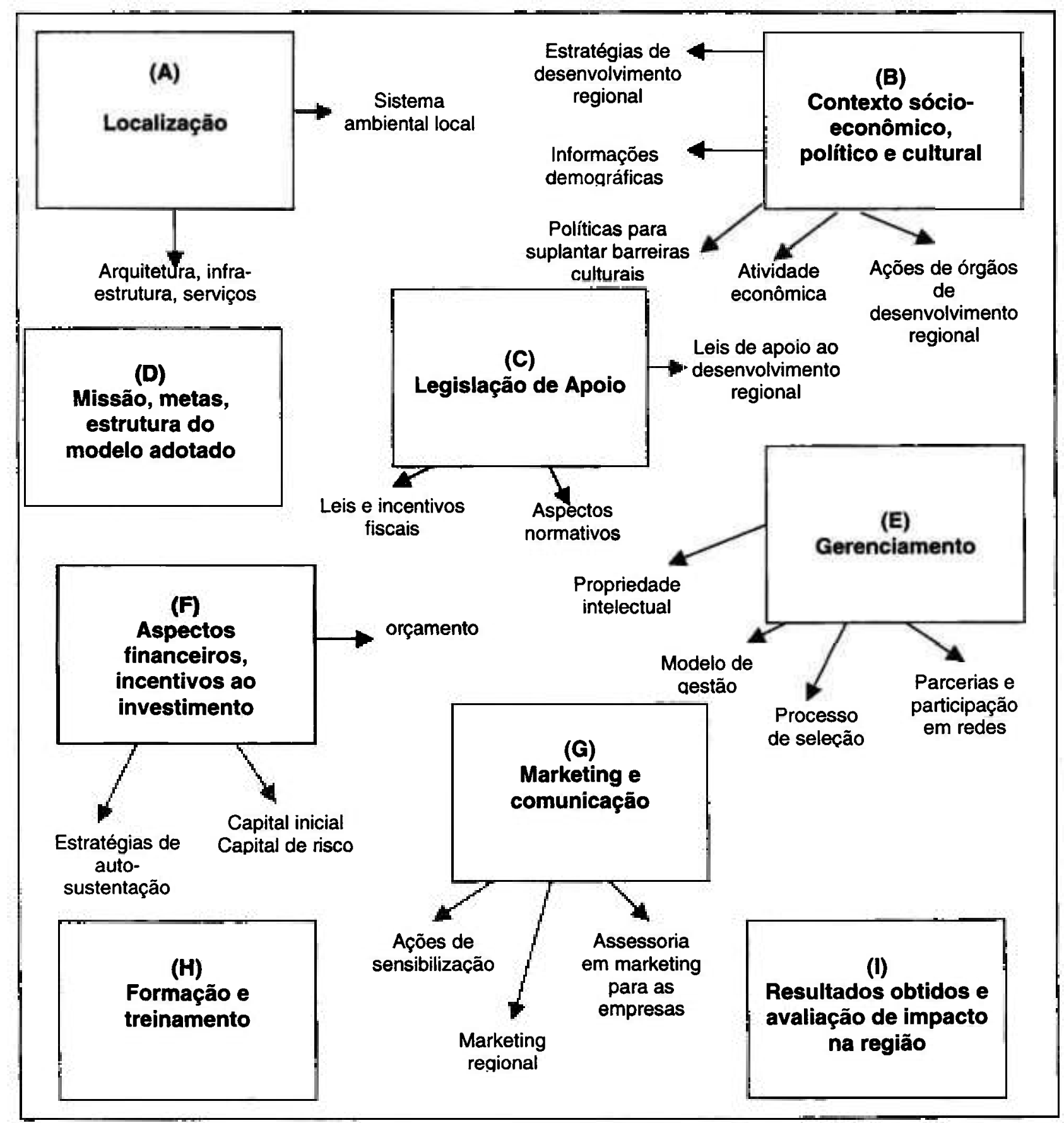

FIGURA 4.1: Dimensões consideradas na pesquisa de campo

$O$ instrumento de pesquisa foi discutido com pesquisadores que atuam nesta área de pesquisa (Professores Doutores Cláudio Rodrigues, Conceição Vedovello, Guilherme Ary Plonski e José Roberto Rogero). Com as sugestões propostas, foi possivel aperfeiçoar e melhorar o instrumento de pesquisa.

O questionário foi aplicado por meio da Internet, após obtida a concordância dos entrevistados para a participação na pesquisa. A aplicação do 
questionário foi acompanhada de uma série de explicações sobre a metodologia e a terminologia utilizada. Algumas dúvidas apresentadas pelos entrevistados foram respondidas por meio eletrônico. Em seguida, os questionários respondidos foram tabulados e preparadas as entrevistas.

Para as experiências estrangeiras, principalmente Portugal e Espanha, os formulários, contatos e esclarecimentos foram todos feitos por meio eletrônico, tendo em vista a impossibilidade de realizar entrevistas pessoais. Quanto a Israel, a vinda de um especialista e pesquisador da área ao Brasil, permitiu a realização da entrevista complementar.

Algumas atualizações das respostas foram necessárias, durante 0 ano de 2002, tendo sido as mesmas incorporadas às respostas fornecidas anteriormente e consideradas nos textos dos capítulos 5 e 6 . 


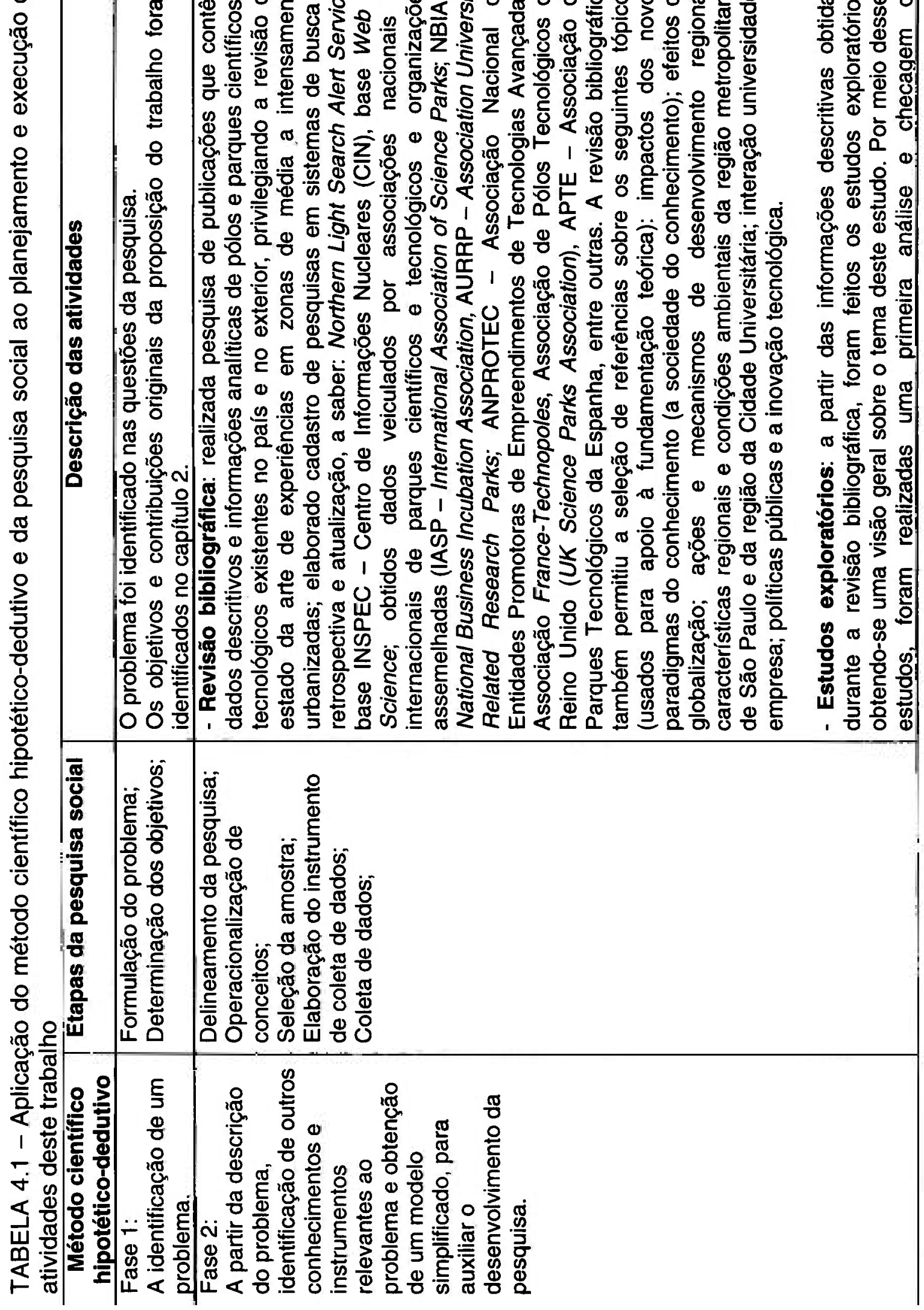




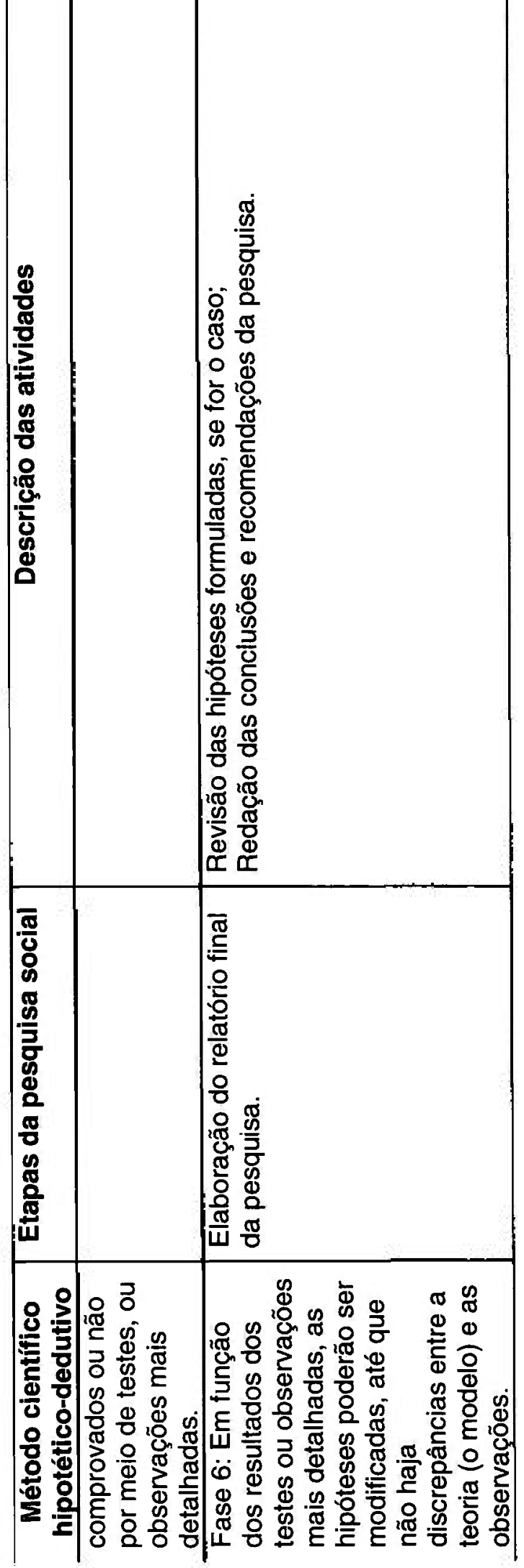




\section{RESULTADOS}

"Se definimos ciência, de acordo com Sir Peter Medawar, como a Arte do Possivel, podemos igualmente definir estatistica e mesmo todas as técnicas de tratamento de dados como a Arte do Conhecimento. Quando reduzimos os dados a indicadores do valor central, grau de dispersão e outras parametrizações, nossa intenção é, em primeiro lugar, obter informação a partir de dados. Em seguida, tentamos convencer-nos de que nossa hipótese é correta (ou não). Finalmente, na etapa mais difícil do processo tentamos convencer terceiros, principalmente por meio de publicações, de que nossos resultados são corretos."

(Júlio César Rodrigues Pereira) ${ }^{\dagger}$

Os capítulos 5 e 6 correspondem à terceira fase da metodologia apresentação, análise e interpretação dos dados - conforme exposto na TAB. 4.1

Os resultados organizados em tabelas e matrizes, apresentados a seguir, foram obtidos a partir da aplicação do instrumento de pesquisa às experiências selecionadas, bem como aos estudos exploratórios realizados. $\mathrm{Na}$ TAB. 5.1 são apresentados os dados cadastrais das experiências analisadas na pesquisa de campo. Foram consideradas na pesquisa as experiências nacionais que, entre as selecionadas, concordaram em participar da pesquisa, bem como as experiências internacionais que, do mesmo modo, concederam em participar deste estudo.

TABELA 5.1 - Dados cadastrais das experiências analisadas na pesquisa de campo

\begin{tabular}{l|l|l}
\hline \multicolumn{1}{c|}{ Nome } & \multicolumn{1}{|c|}{ Dados cadastrais } & \multicolumn{1}{|c}{$\begin{array}{c}\text { Responsável pelas } \\
\text { informações }\end{array}$} \\
\hline $\begin{array}{l}\text { (1) Pólo de Informática } \\
\text { de São Leopoldo (RS) }\end{array}$ & $\begin{array}{l}\text { Av. UNISINOS 950, São Leopoldo, Prédio UNITEC, } \\
\text { CEP 93320-003, Cidade de São Leopoldo, RS } \\
\text { Telefone: (51) 590 8600 } \\
\text { edemar@indus.unisinos.br; } \\
\text { www.polodeinformatica.com.br }\end{array}$ & $\begin{array}{l}\text { Edemar Antônio Wolf } \\
\text { de Paula } \\
\text { Gerente da UNITEC }\end{array}$ \\
\hline $\begin{array}{l}\text { (2) PADETEC - } \\
\text { Parque de } \\
\text { Desenvolvimento } \\
\text { Tecnológico (CE) }\end{array}$ & $\begin{array}{l}\text { Av. do Contorno, bloco 310 - Campus do PICI - - } \\
\text { Universidade do Ceará, Caixa Postal 6022, CEP 60455- }\end{array}$ & $\begin{array}{l}\text { Ary Marques da Silva } \\
\text { Superintendente } \\
\text { Adjunto }\end{array}$ \\
\hline $\begin{array}{l}\text { Telefone: (85) 2874779 } \\
\text { ary@.jadetec.ufc.br; www.padetec.ufc.br }\end{array}$ & \\
\hline
\end{tabular}

I PEREIRA, J.C.R. Análise de Dados Qualitativos - Estratégias Metodológicas para as Ciências da Saúde, Humanas e Sociais. São Paulo, S.P.: Editora Universidade de São Paulo, 1999. 


\begin{tabular}{|c|c|c|}
\hline Nome & Dados cadastrais & $\begin{array}{l}\text { Responsável pelas } \\
\text { informações }\end{array}$ \\
\hline $\begin{array}{l}\text { (3) Porto Alegre } \\
\text { Tecnópole (RS) }\end{array}$ & $\begin{array}{l}\text { Secretaria Municipal da Produção, Indústria e } \\
\text { Comércio, Prefeitura de Porto Alegre, Rua dos } \\
\text { Andradas } 680,2^{\circ} \text { andar, sala 208, Porto Alegre, RS } \\
\text { Telefone: (51) } 2141779\end{array}$ & $\begin{array}{l}\text { Ghissia Hauser } \\
\text { Supervisora }\end{array}$ \\
\hline $\begin{array}{l}\text { (4) Londrina } \\
\text { Tecnópolis (PR) }\end{array}$ & $\begin{array}{l}\text { Associação do Desenvolvimento Tecnológico de } \\
\text { Londrina. Av. Santos Dumont 505, } 2^{\circ} \text { andar, sala 204, } \\
\text { Londrina, Paraná } \\
\text { Telefone: (43) } 3243212 \\
\text { lecnopolis (a) adetec.org.br; www.adetec.org.br }\end{array}$ & $\begin{array}{l}\text { Mauro Silva Ruiz } \\
\text { Gerente técnico } \\
\text { José Antonio Tadeu } \\
\text { Felismino } \\
\text { Coordenador Executivo } \\
\end{array}$ \\
\hline (5) Porto Digital (PE) & $\begin{array}{l}\text { Rua Domingos José Martins, 227, Recife, Pernambuco, } \\
\text { CEP 50030-170 } \\
\text { Telefone: (81) } 34246444 \\
\text { portodigital (a portodigital.org; www.portodigital.org }\end{array}$ & $\begin{array}{l}\text { Maria Paula Gonçalves } \\
\text { Gerente }\end{array}$ \\
\hline $\begin{array}{l}\text { (6) Pólo de Alta } \\
\text { Tecnologia de } \\
\text { Campinas (SP) }\end{array}$ & $\begin{array}{l}\text { CIATEC - Companhia de Desenvolvimento do Pólo de } \\
\text { Alta Tecnologia de Campinas, Rua Lauro Vanucci, } \\
\text { 1020, Jardim Santa Cândida, Campinas, SP, CEP } \\
13087-410 \\
\text { www.ciatec.org.br }\end{array}$ & $\begin{array}{l}\text { José Carlos Valladão de } \\
\text { Mattos } \\
\text { Diretor Superintendente } \\
\text { do CIATEC }\end{array}$ \\
\hline $\begin{array}{l}\text { (7) Parque } \\
\text { Tecnológico do Rio de } \\
\text { Janeiro (RJ) }\end{array}$ & $\begin{array}{l}\text { Parque Tecnológico do Rio de Janeiro, Cidade } \\
\text { Universitária, Caixa Postal 68.568, CEP 21945-970, } \\
\text { Rio de Janeiro, RJ } \\
\text { parqlec (a inc.conpe.ufri.hr }\end{array}$ & $\begin{array}{l}\text { Mauricio Guedes } \\
\text { Gerente }\end{array}$ \\
\hline $\begin{array}{l}\text { (8) Kiryat Weizmann } \\
\text { Science Park (Israel) }\end{array}$ & $\begin{array}{l}\text { Ness Ziona 70400, Israel } \\
\text { Telefone: }(+) 972-8-9301214 \\
\text { Fax: }(+) 972-8-9301211 \\
\text { sharons (a) africa-israel.com; www.africa-israel.com }\end{array}$ & $\begin{array}{l}\text { Samuel Jerozolimski } \\
\text { Consultor } \\
\text { Sharon Chetrit } \\
\text { Diretor } \\
\end{array}$ \\
\hline $\begin{array}{l}\text { (9) Parque } \\
\text { Tecnológico de } \\
\text { Andalucia S.A. } \\
\text { (Espanha) }\end{array}$ & $\begin{array}{l}\text { Rua Maria Curie, 35, Campanillas, 29590, Málaga, } \\
\text { Espanha } \\
\text { Telefone: (34) } 52619114 \\
\text { Fax: (34) } 52619117 \\
\text { fromera@ cst.pta.es; spalomo@cst.pta.es; www.pta.es }\end{array}$ & $\begin{array}{l}\text { Sonia Palomo das } \\
\text { Neves }\end{array}$ \\
\hline $\begin{array}{l}\text { (10) TAGUSPARQUE } \\
\text { S.A. (Portugal) }\end{array}$ & $\begin{array}{l}\text { TagusPark - Parque de Ciência e Tecnologia, Núcleo } \\
\text { Central, 100, 2780, Oeiras, Portugal } \\
\text { Telefone: }(351-1) 4226900 / 6001 \\
\text { taguspark@taguspark.pt; } \text { www.taguspark.p1 }\end{array}$ & $\begin{array}{l}\text { Nuno Vasconcelos } \\
\text { Presidente da Comissão } \\
\text { Executiva }\end{array}$ \\
\hline
\end{tabular}

Para auxiliar na análise das experiências selecionadas e identificar as práticas de sucesso, foi elaborada uma matriz lógica (adaptada do conceito Logical Framework ou Logframe) (Ribeiro et al., 1998; Maximiniano, 1997; Roger et al., 1996), acrescida da seleção das práticas de sucesso identificadas. Na TAB. 5.2 é apresentada essa matriz para cada uma das experiências analisadas.

\subsection{Consolidação dos resultados da pesquisa de campo}

Nas TAB. 5.3 a TAB. 5.11 são mostrados os resultados da pesquisa consolidados por dimensão analisada, durante a pesquisa de campo, conforme apresentado no capítulo 4 deste estudo, onde é desenvolvida a metodologia proposta. 


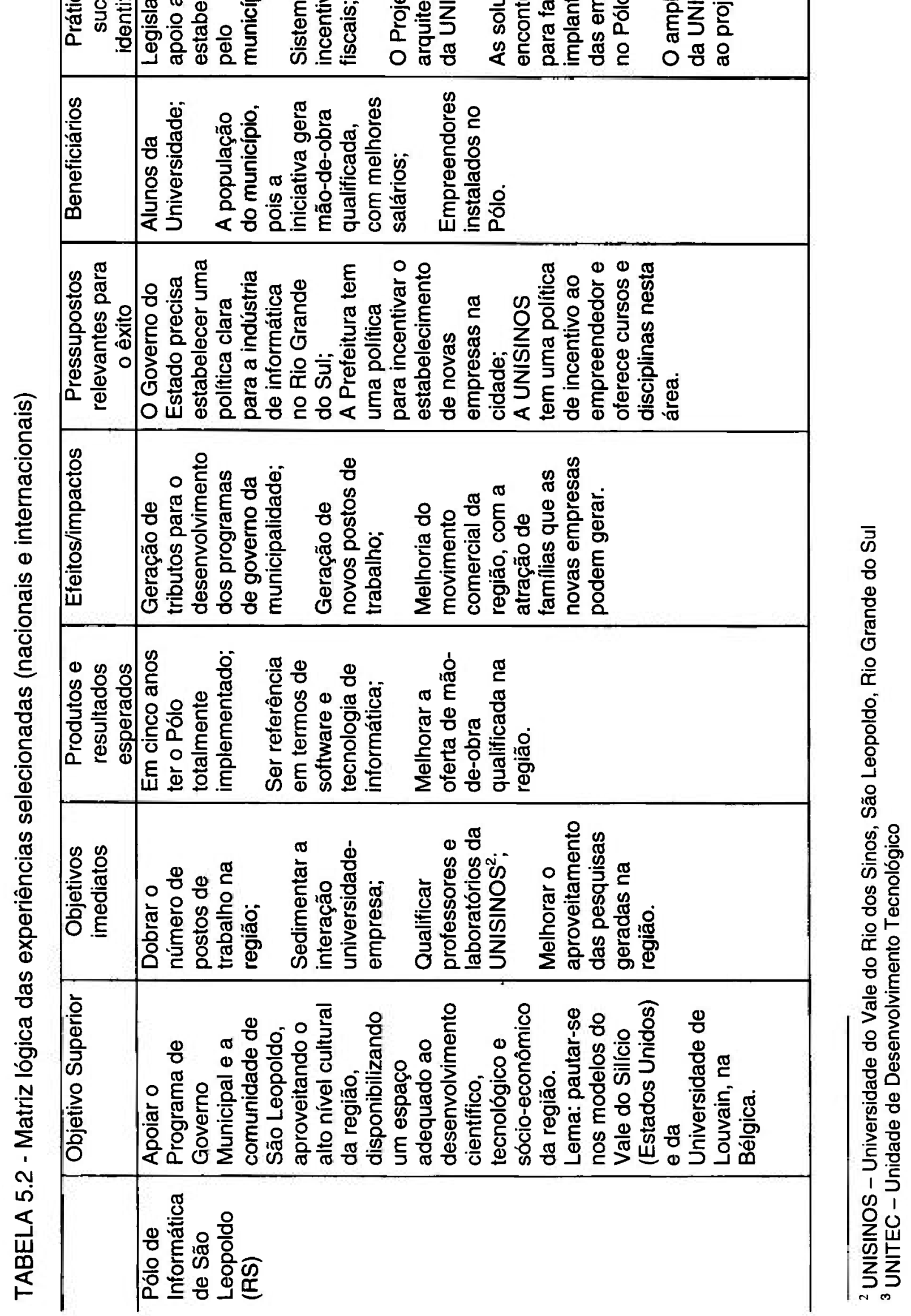




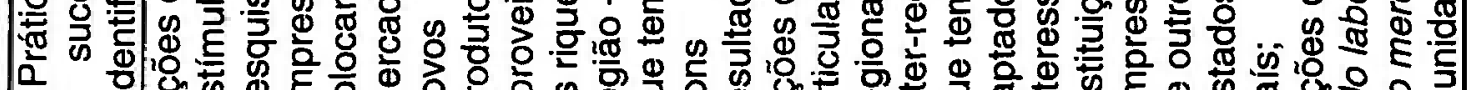

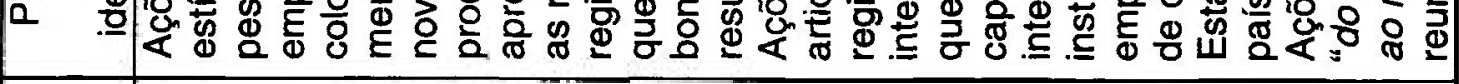

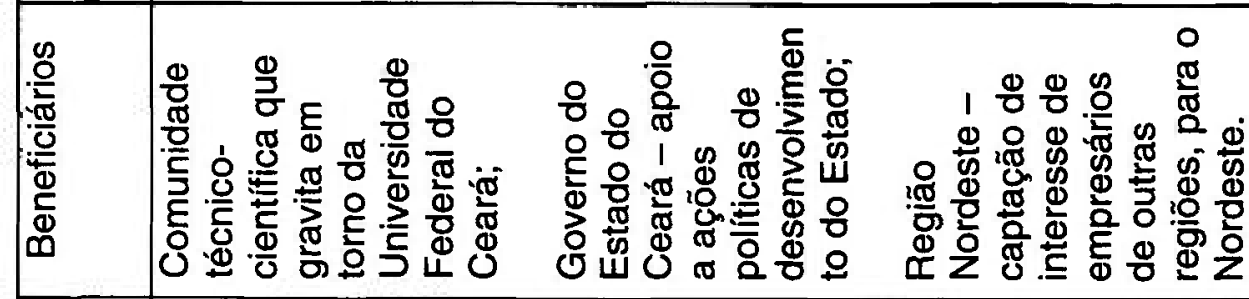

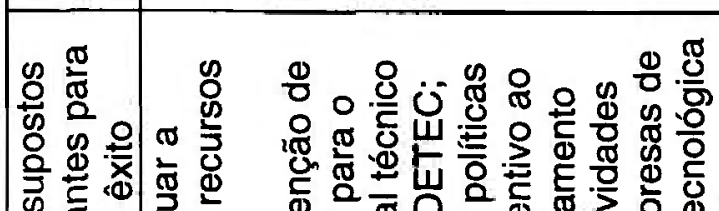

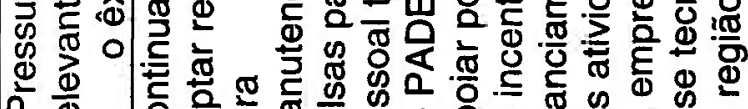

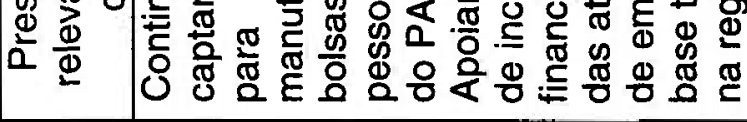

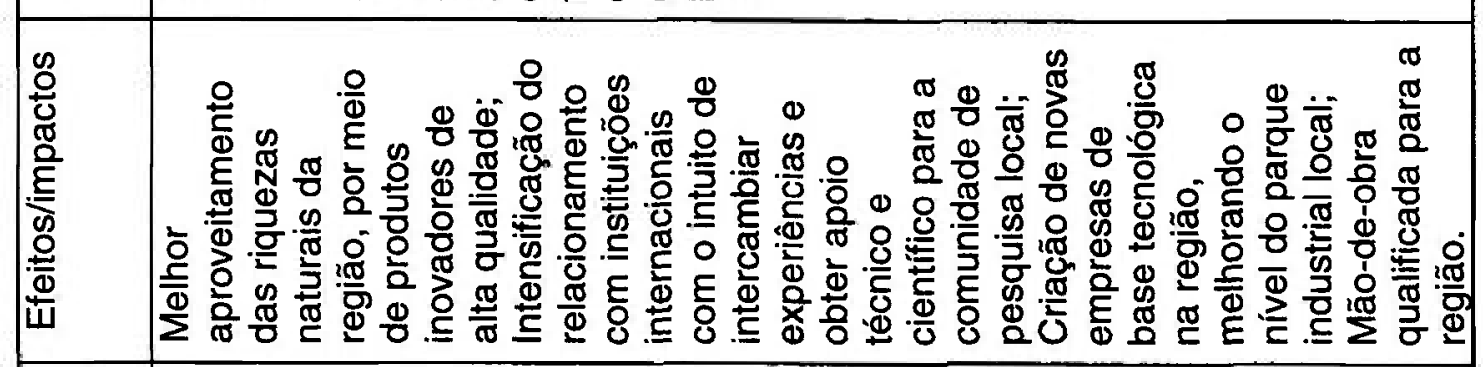

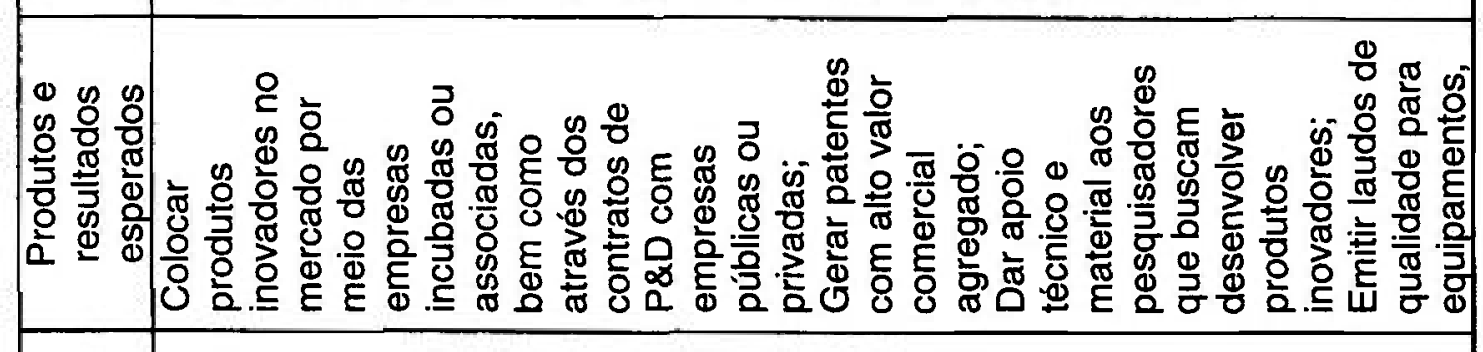

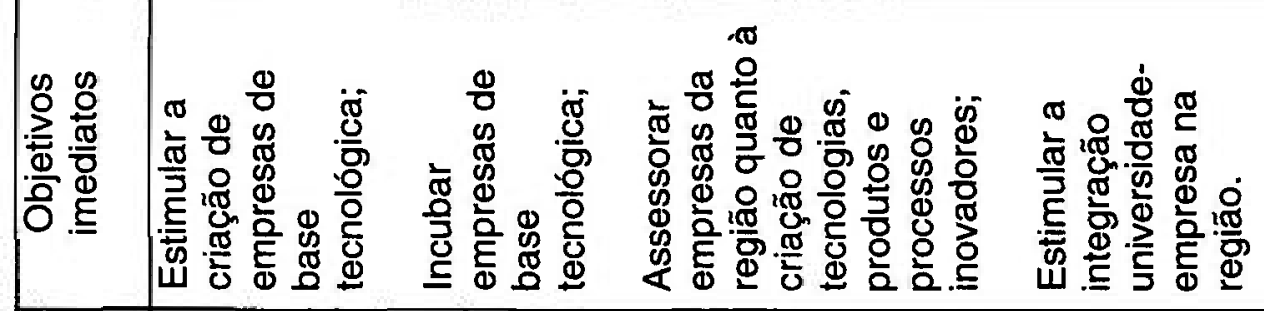

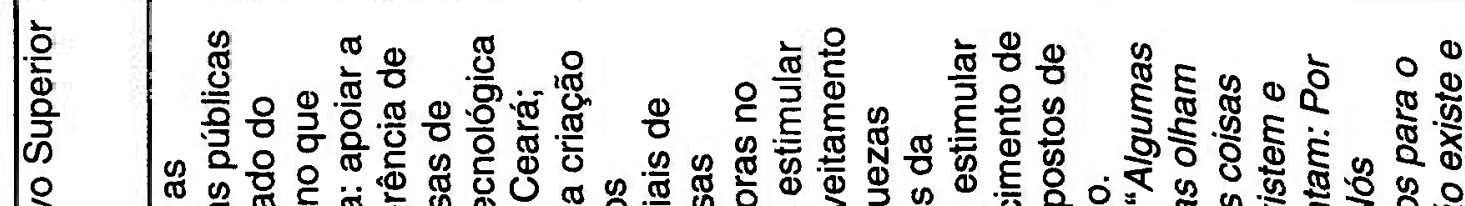

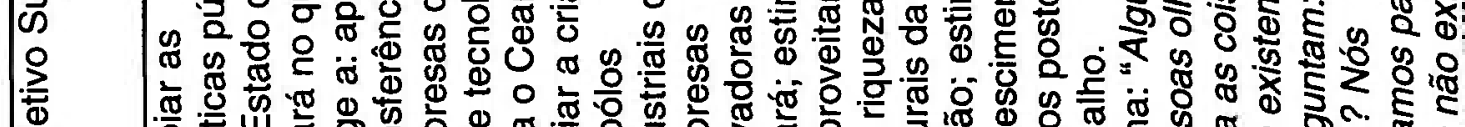
旁

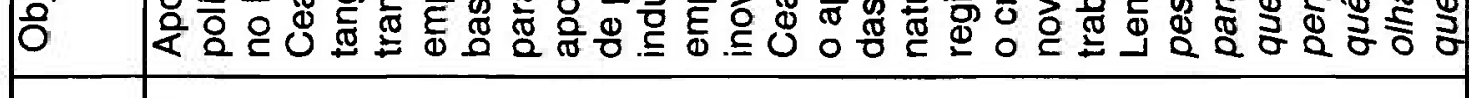

岕 


\begin{tabular}{|c|c|c|}
\hline 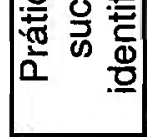 & 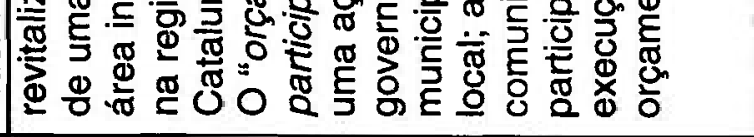 & $\mid$ \\
\hline 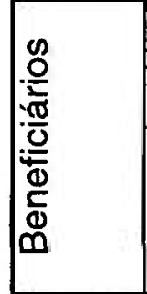 & & 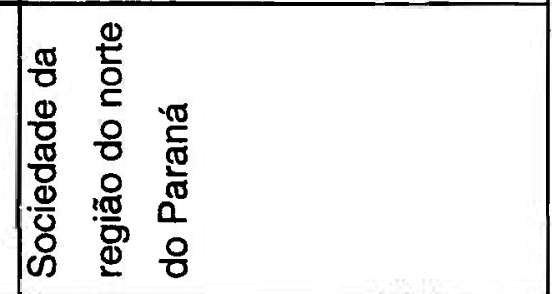 \\
\hline 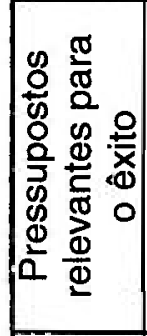 & 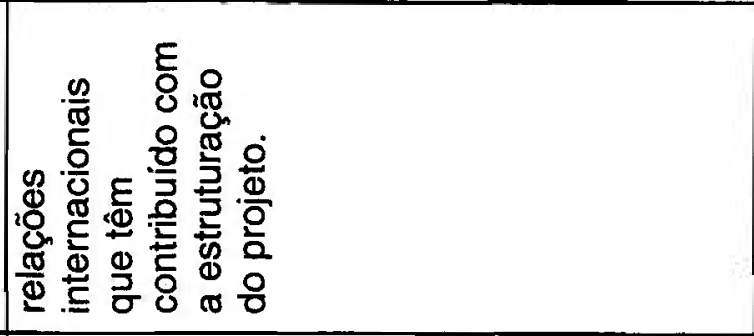 & 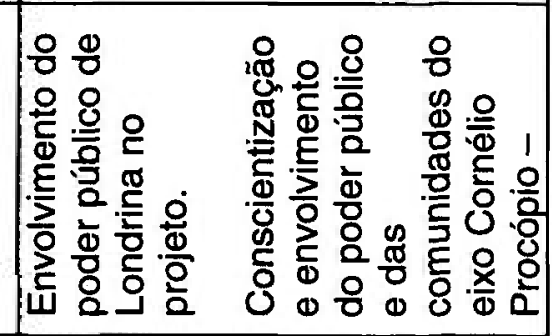 \\
\hline 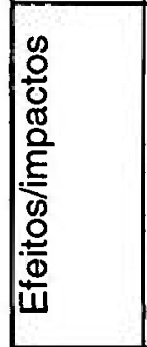 & 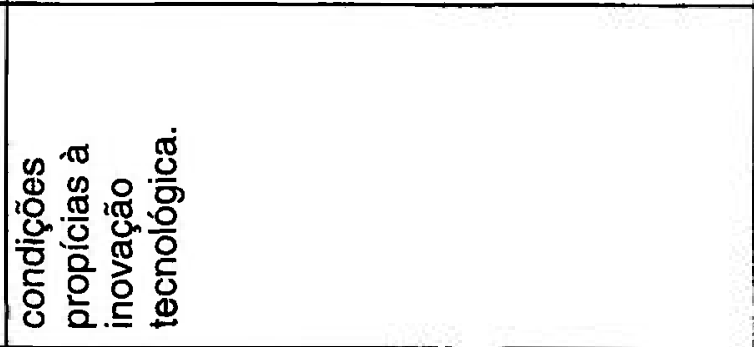 & 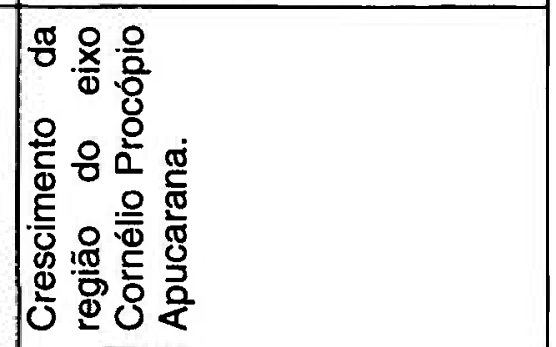 \\
\hline 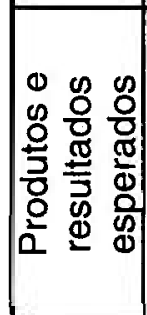 & 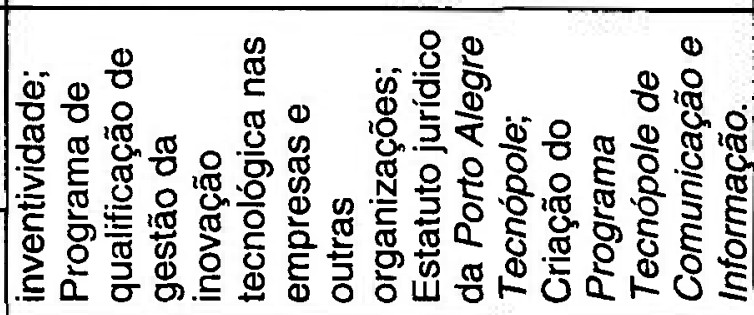 & 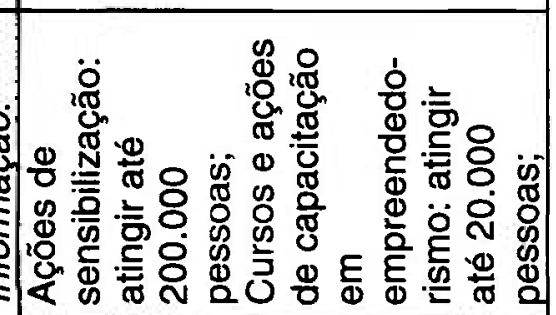 \\
\hline 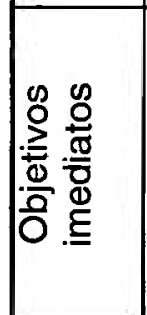 & & 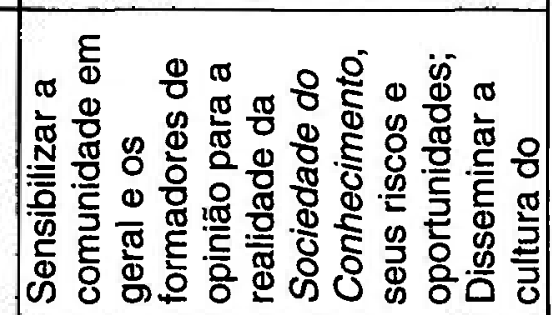 \\
\hline 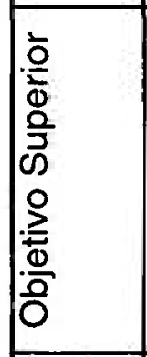 & & 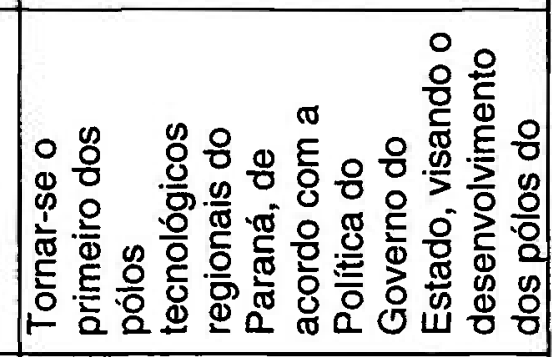 \\
\hline & & 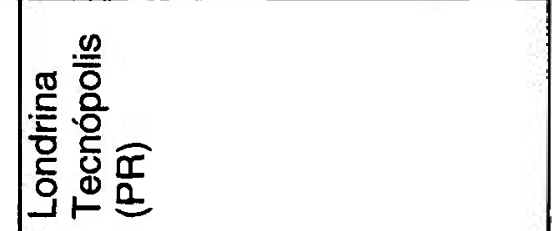 \\
\hline
\end{tabular}




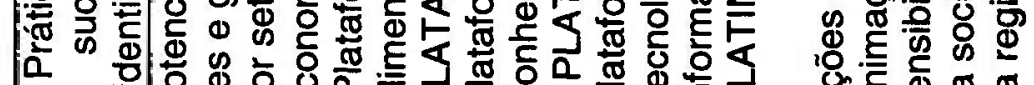

\begin{tabular}{|c|c|}
\hline$\perp \quad$ 의 & 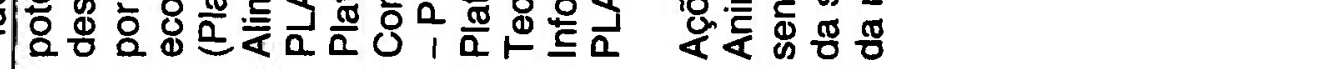 \\
\hline 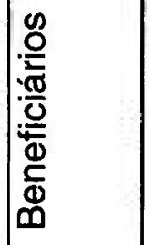 & \\
\hline 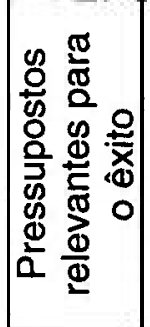 & 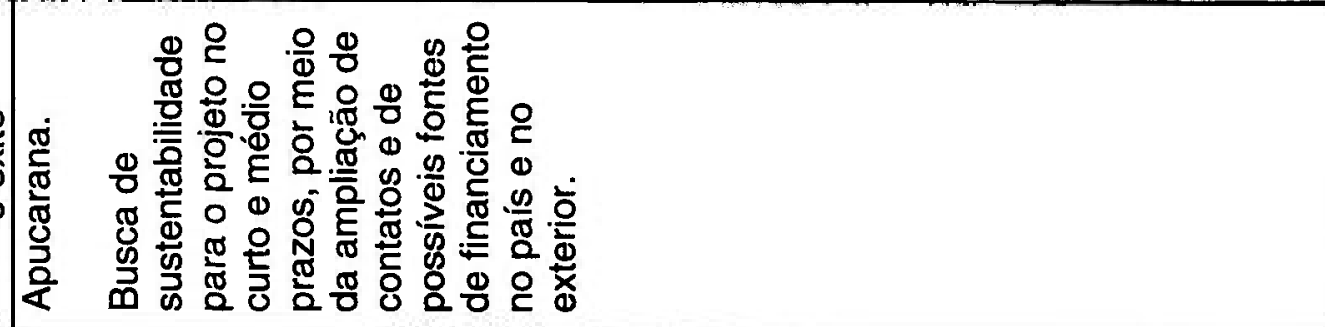 \\
\hline 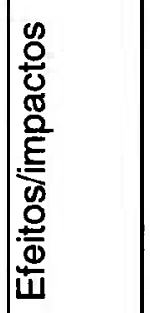 & \\
\hline 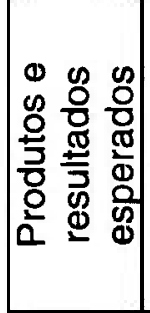 & 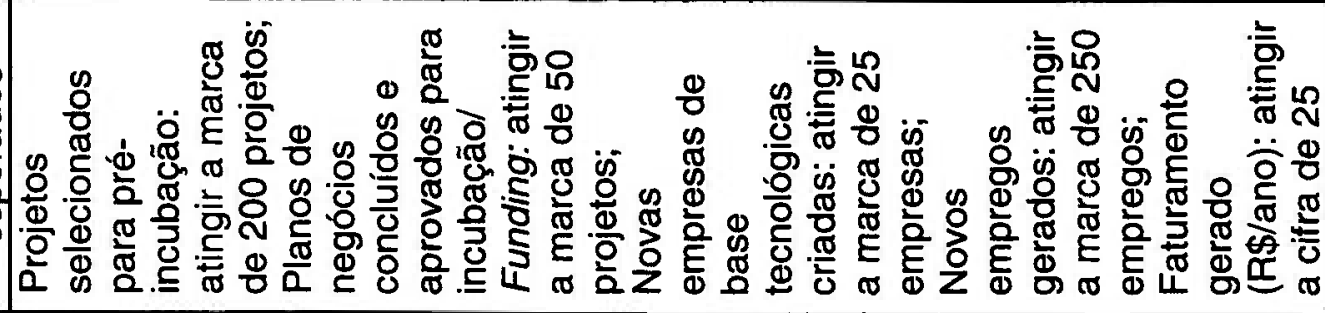 \\
\hline 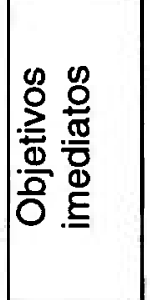 & 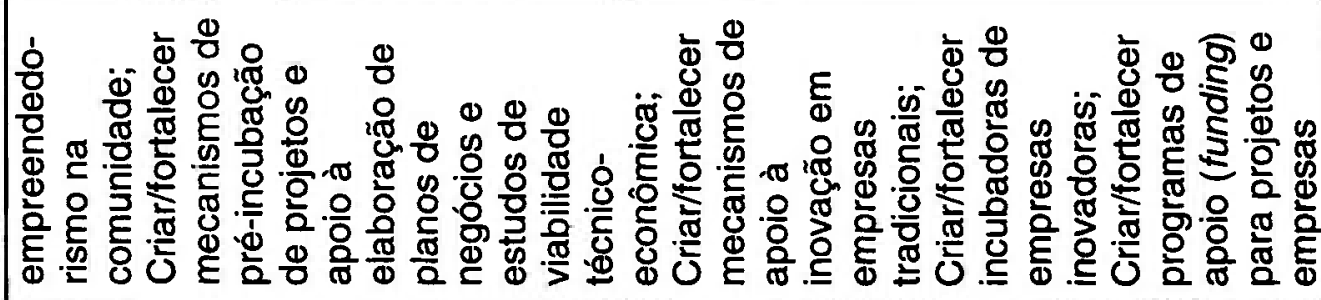 \\
\hline 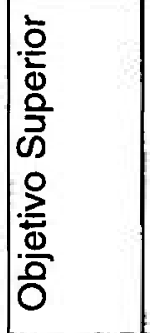 & 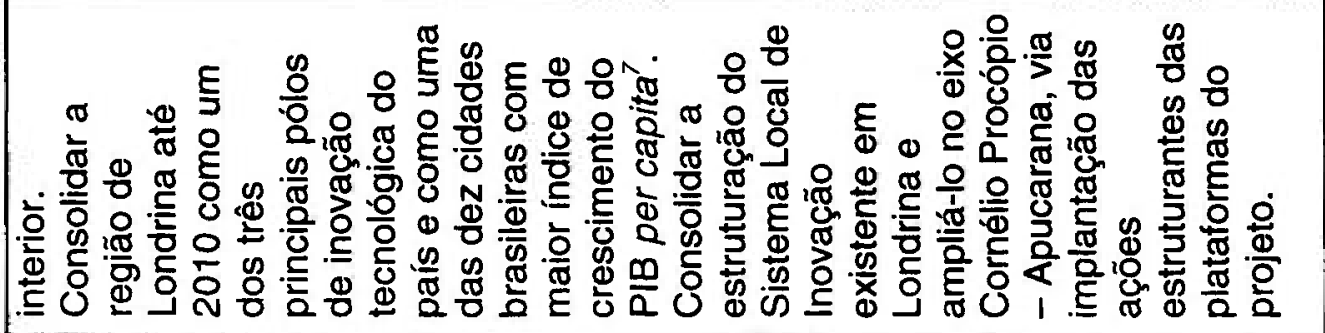 \\
\hline & \\
\hline
\end{tabular}




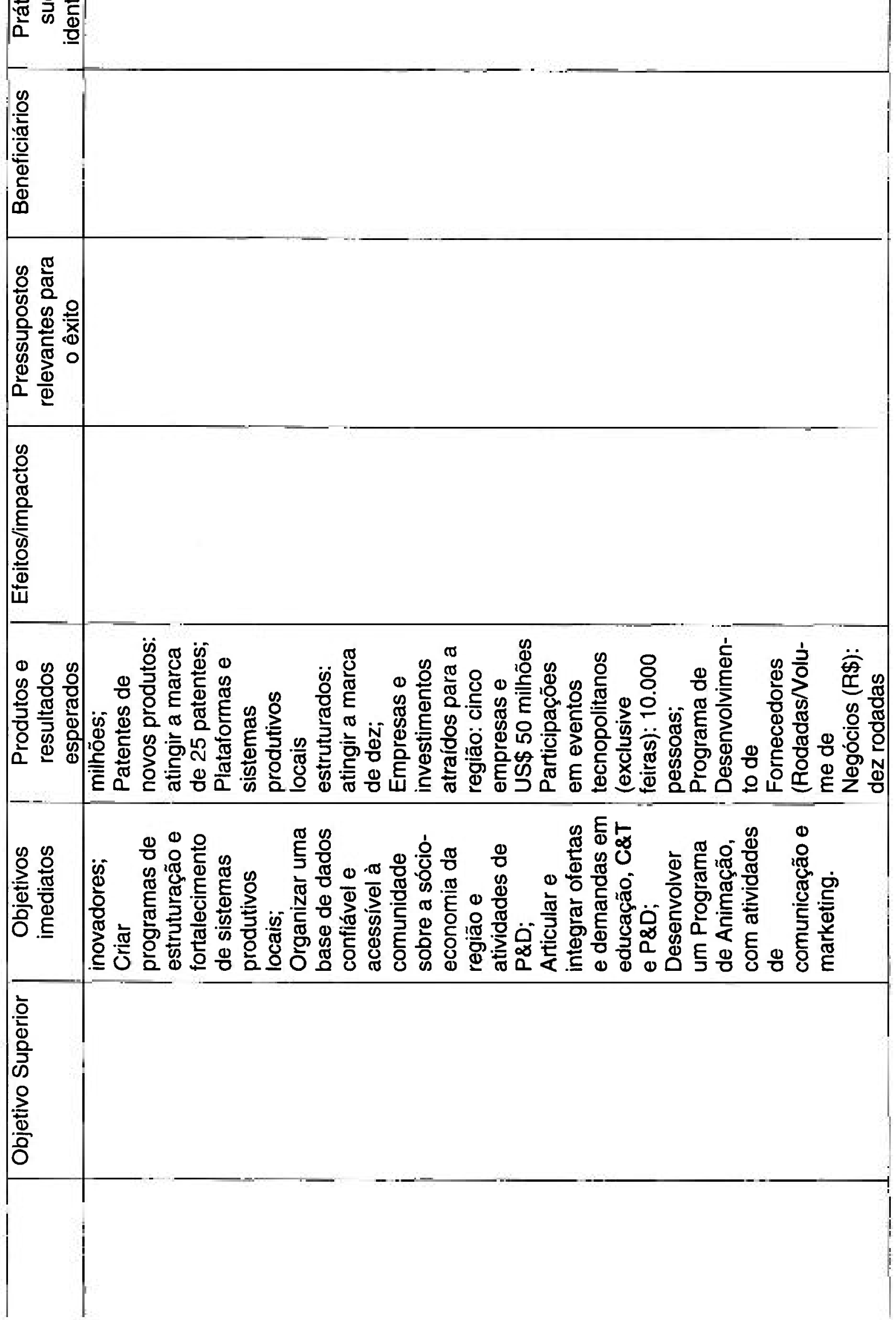









\begin{tabular}{|c|c|c|}
\hline \% & & 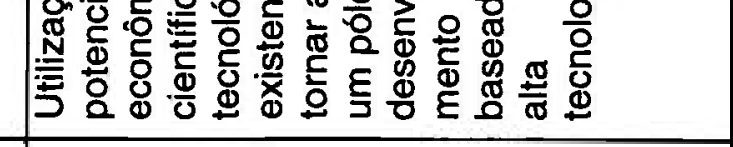 \\
\hline 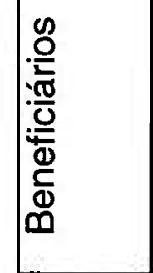 & & 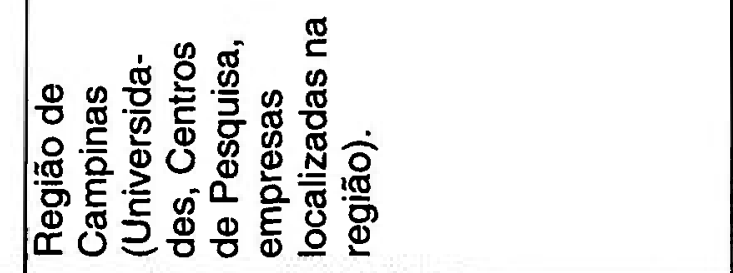 \\
\hline 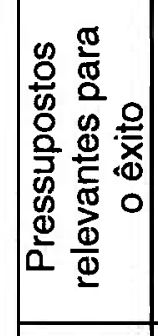 & & 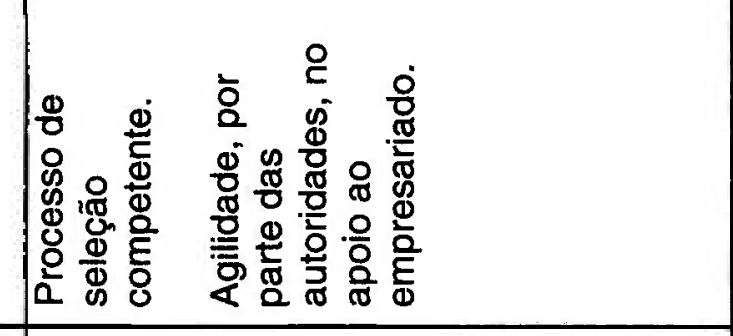 \\
\hline 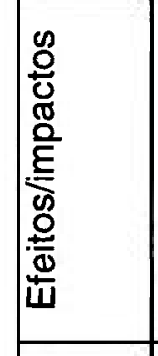 & 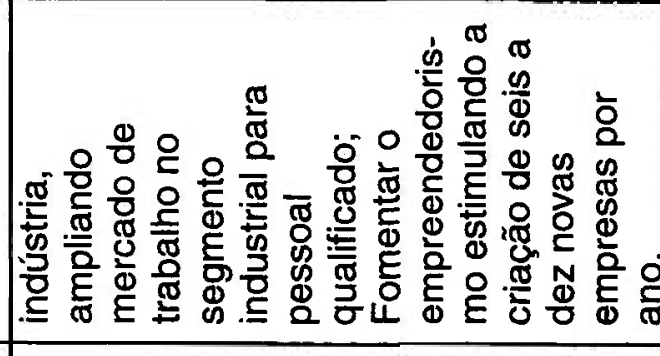 & 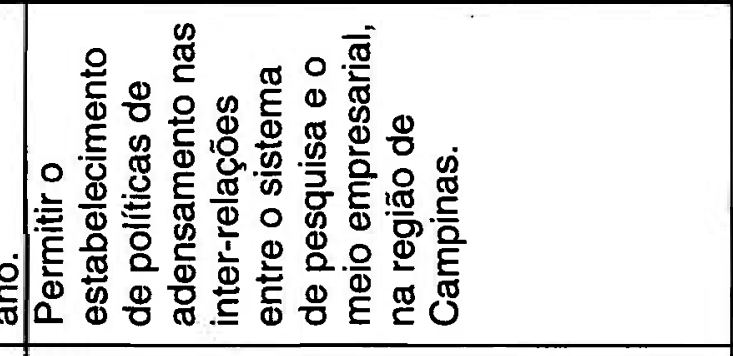 \\
\hline 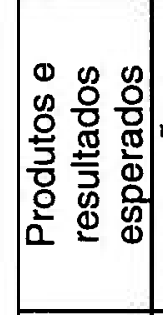 & 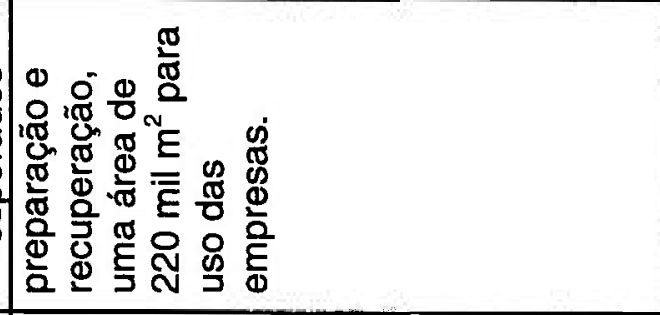 & 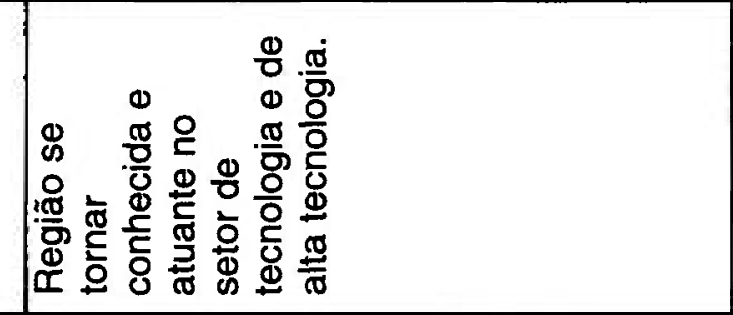 \\
\hline 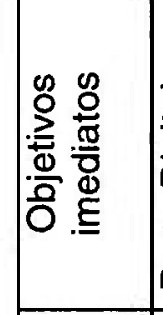 & 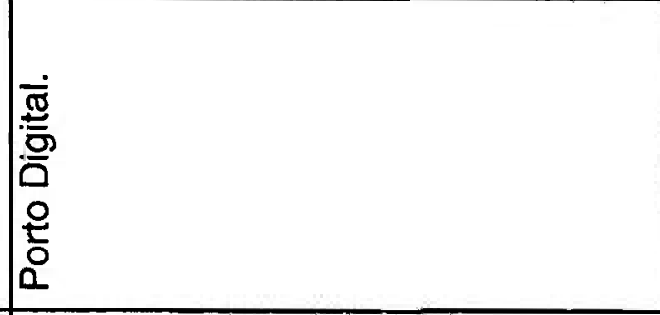 & 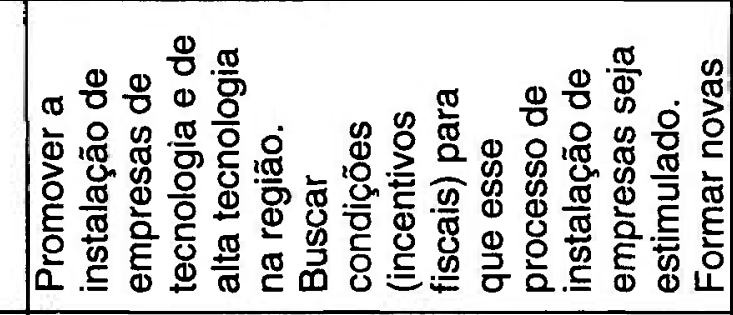 \\
\hline 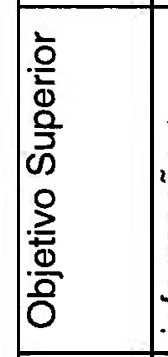 & 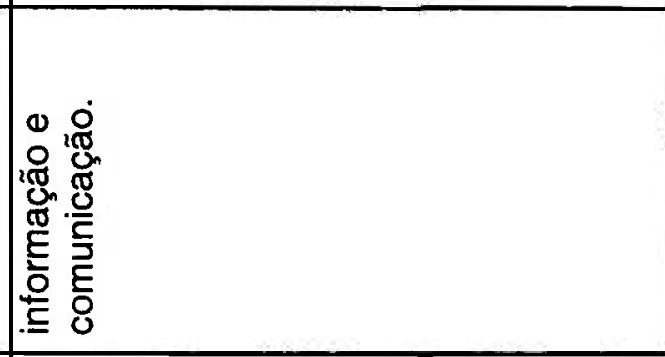 & 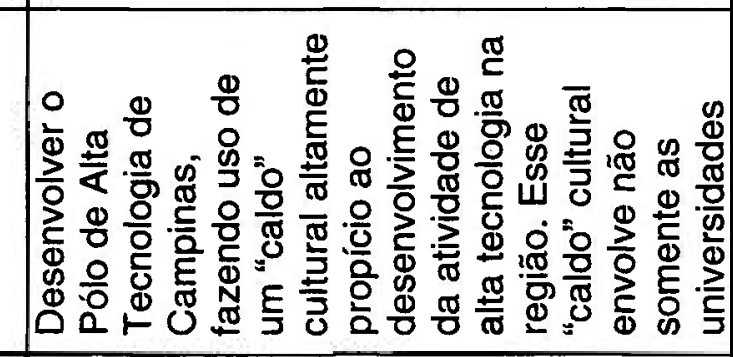 \\
\hline & & 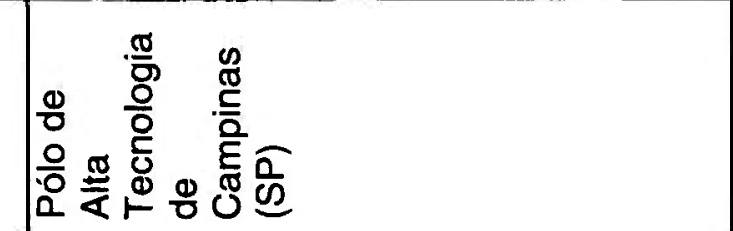 \\
\hline
\end{tabular}




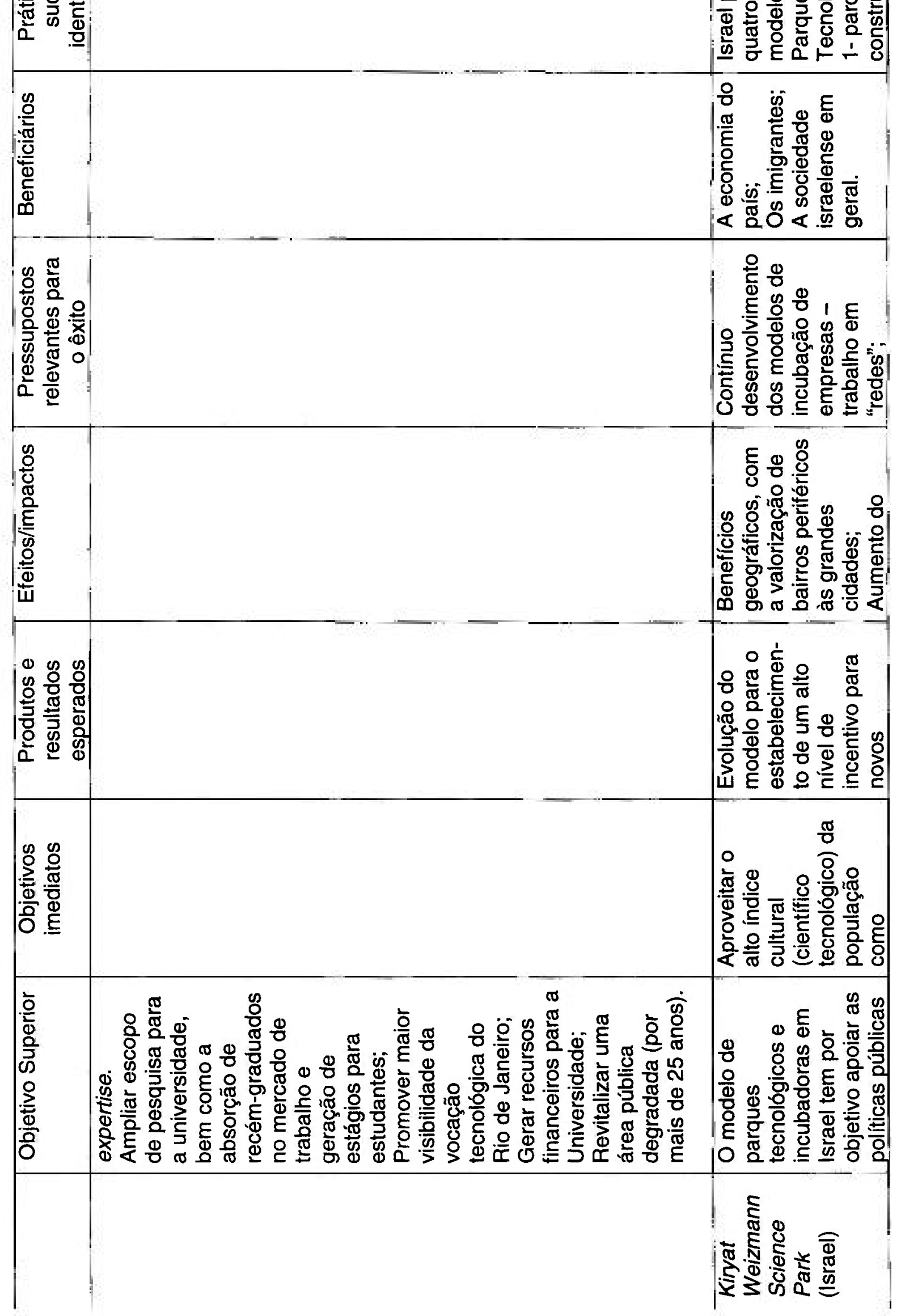




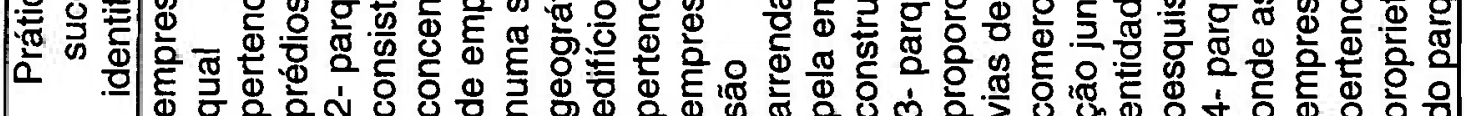

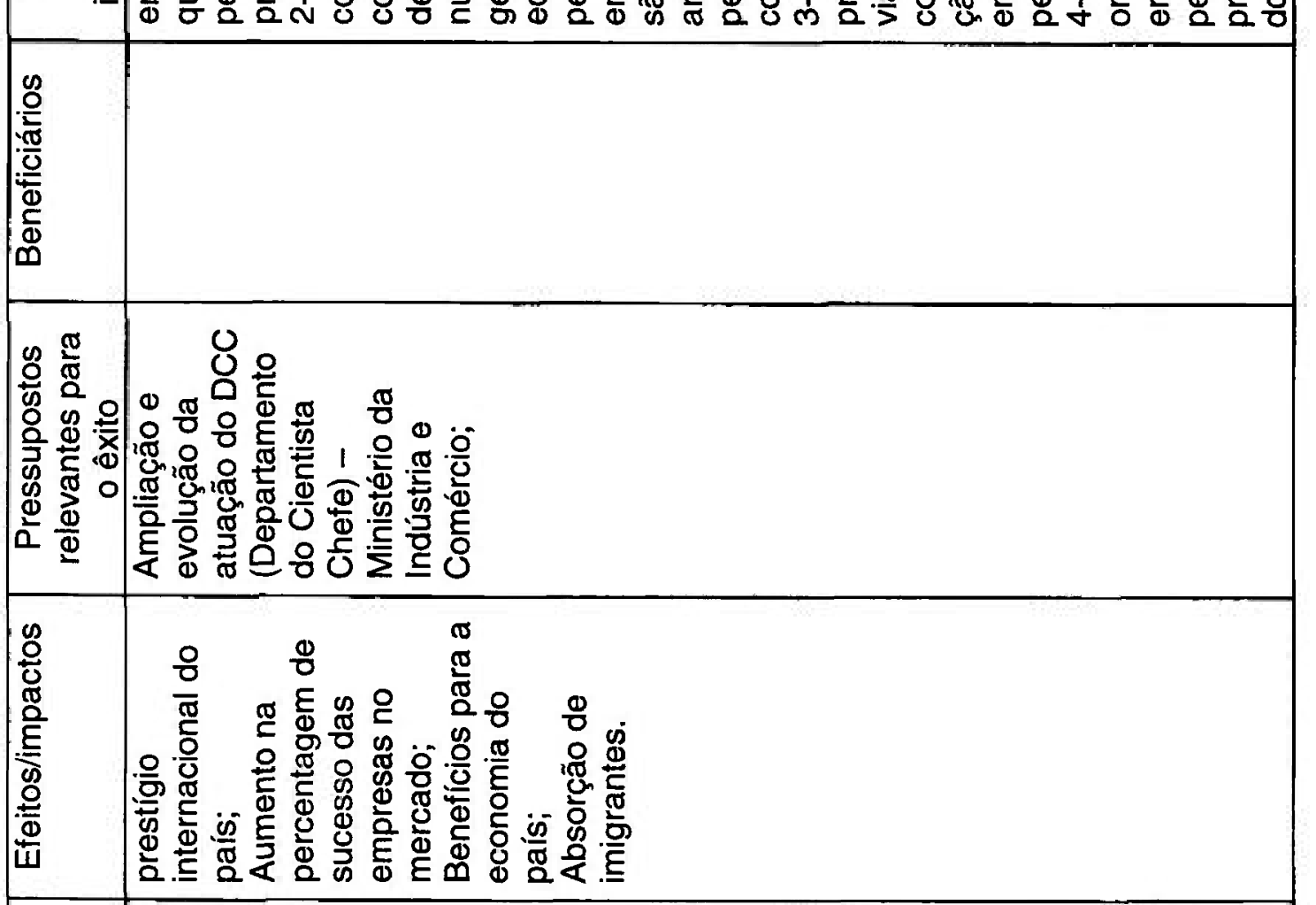

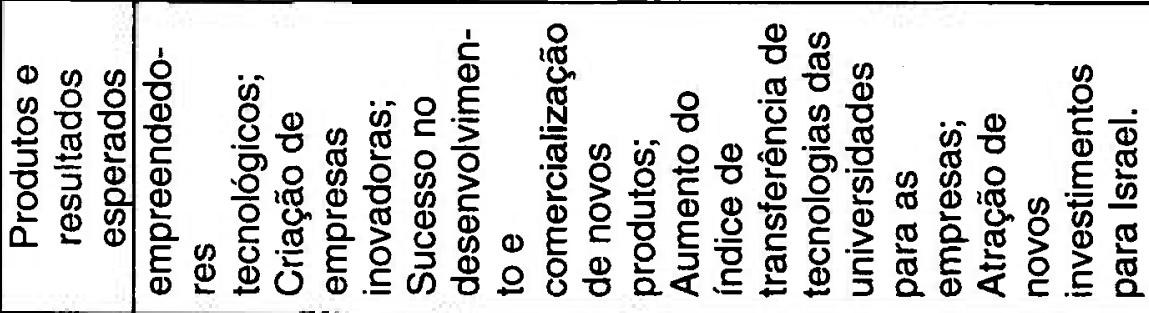

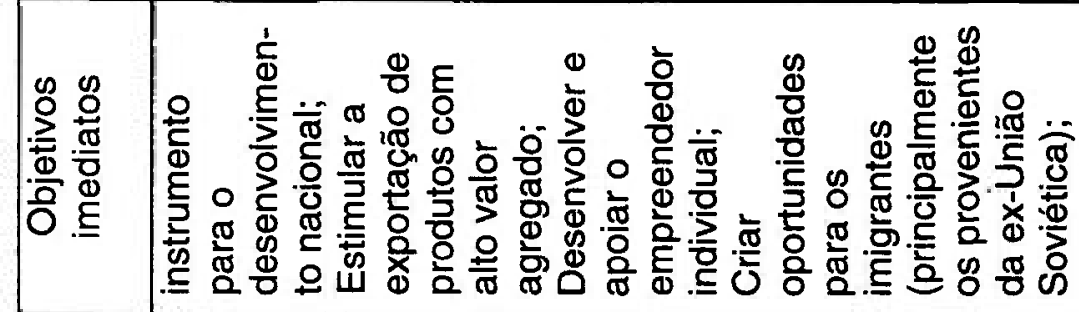

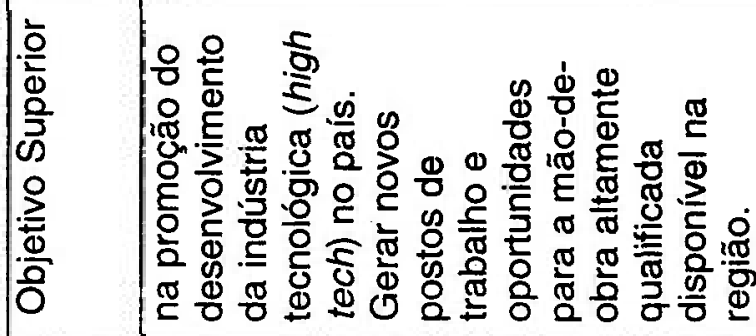









\begin{tabular}{|c|c|c|}
\hline : & & 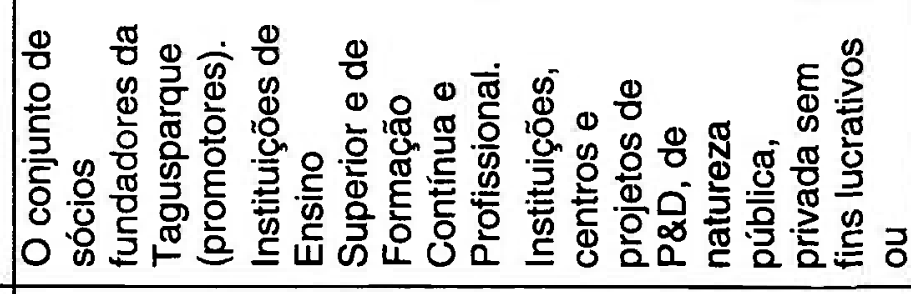 \\
\hline 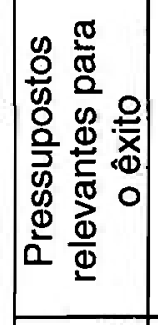 & & 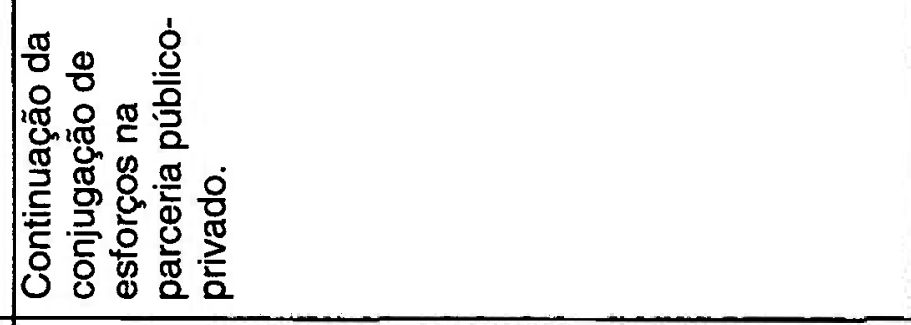 \\
\hline 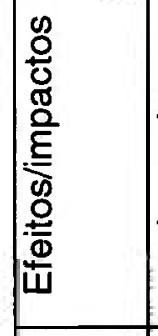 & 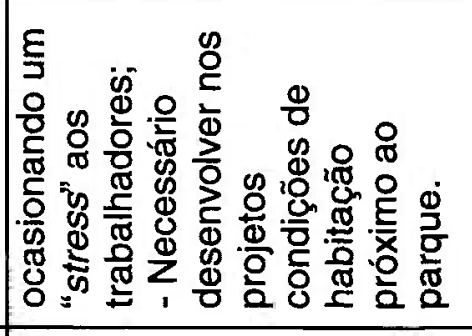 & 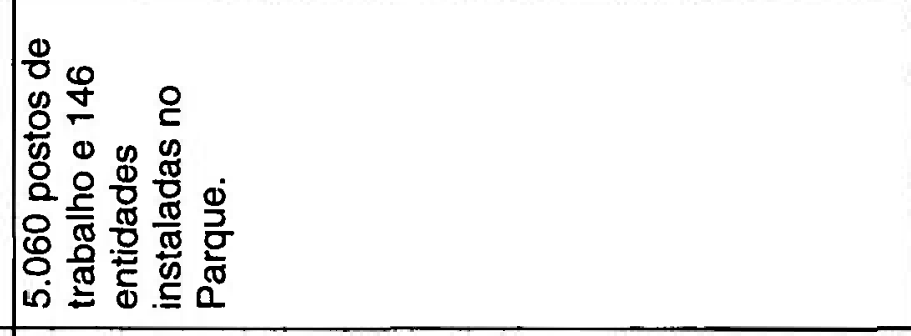 \\
\hline 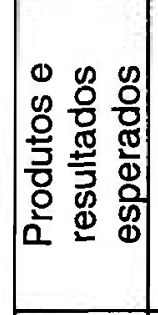 & & 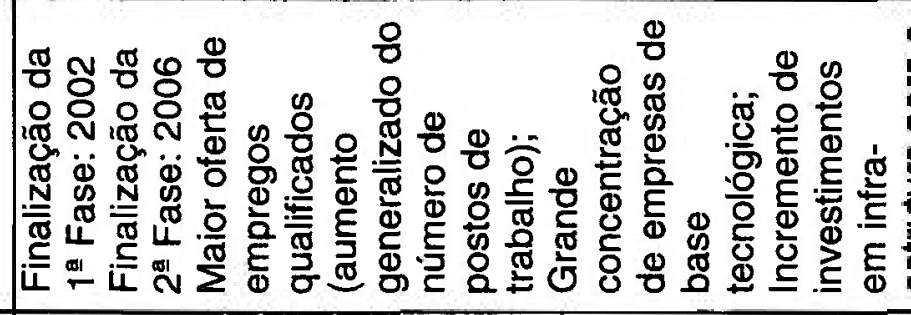 \\
\hline 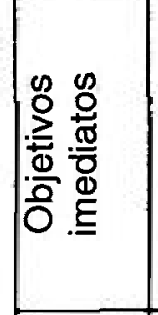 & & 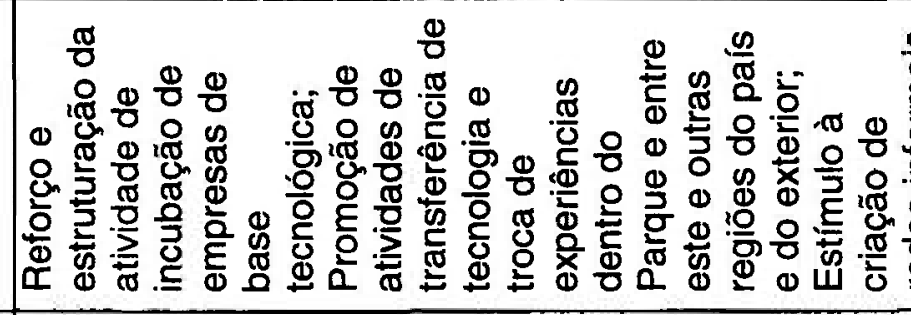 \\
\hline 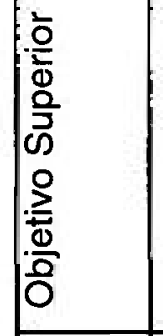 & . & 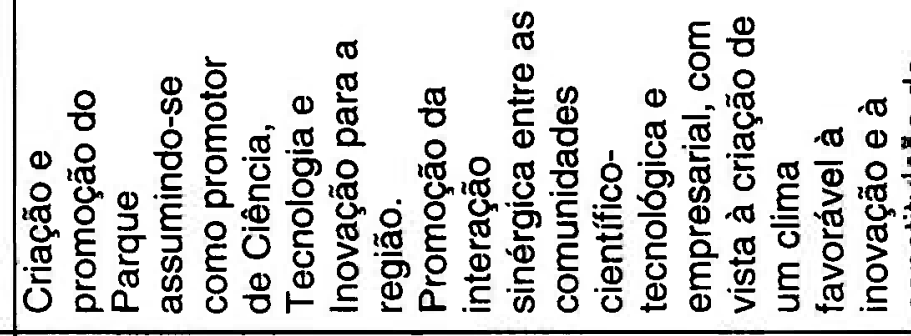 \\
\hline & & 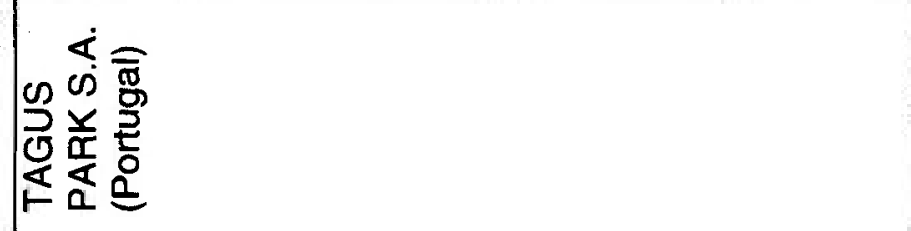 \\
\hline
\end{tabular}




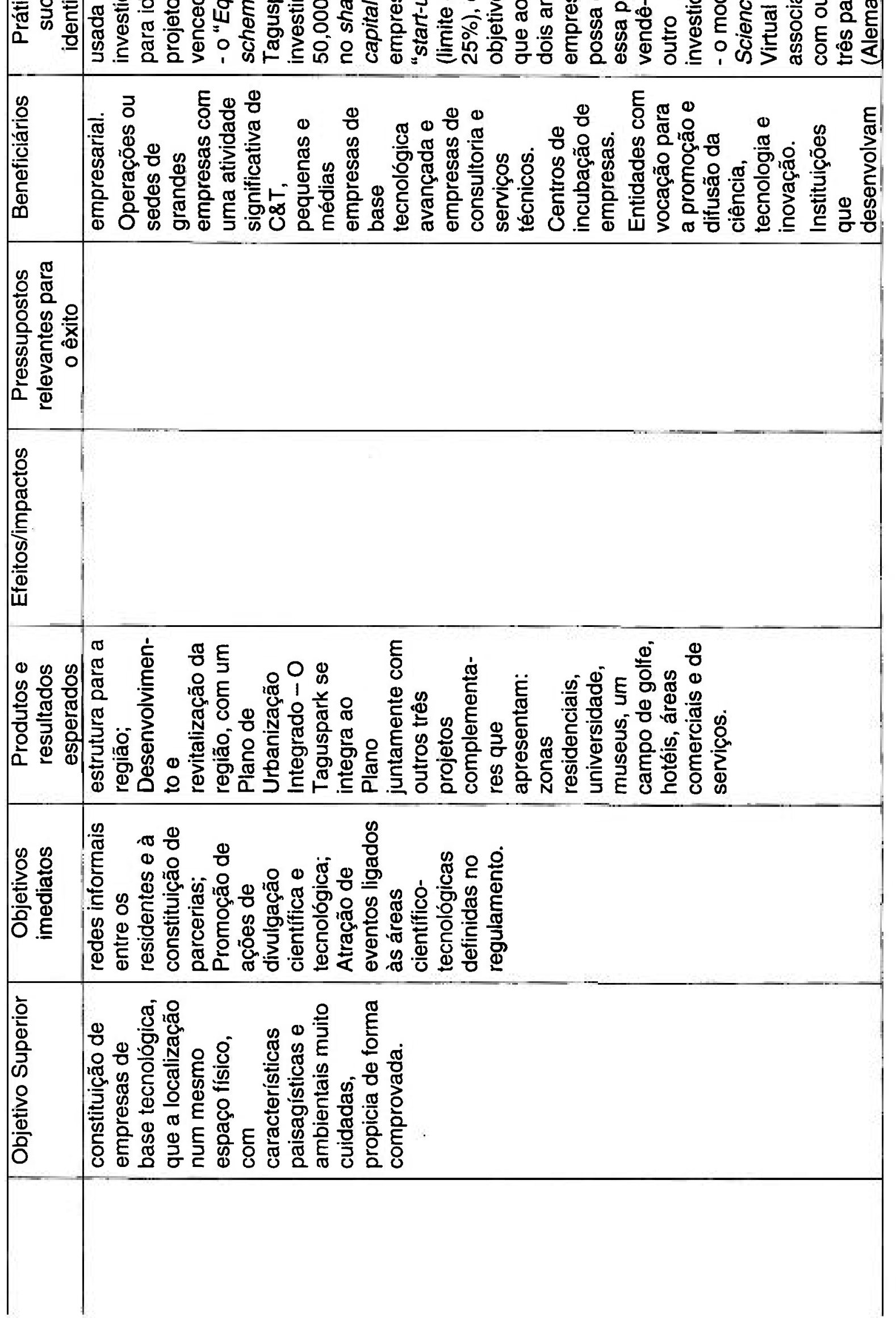




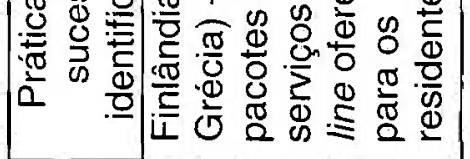

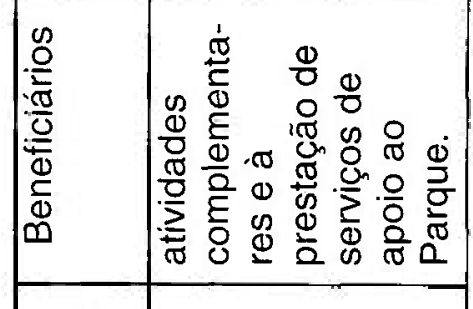

일 $\frac{\pi}{2}$

总

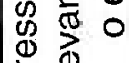

는

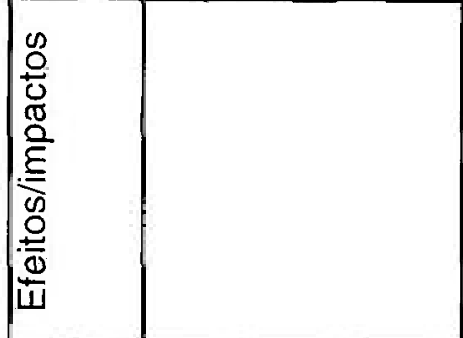

0

녹 $\frac{\Phi}{5} \frac{\pi}{5}$

ฉ.

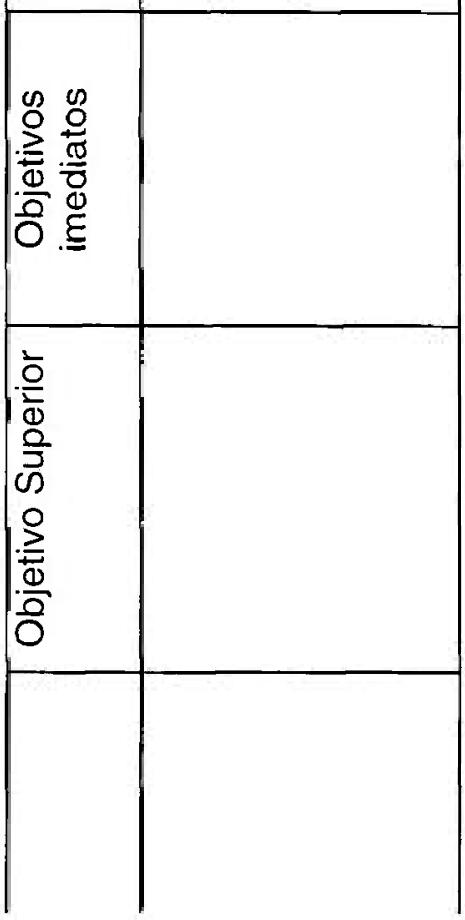

है 


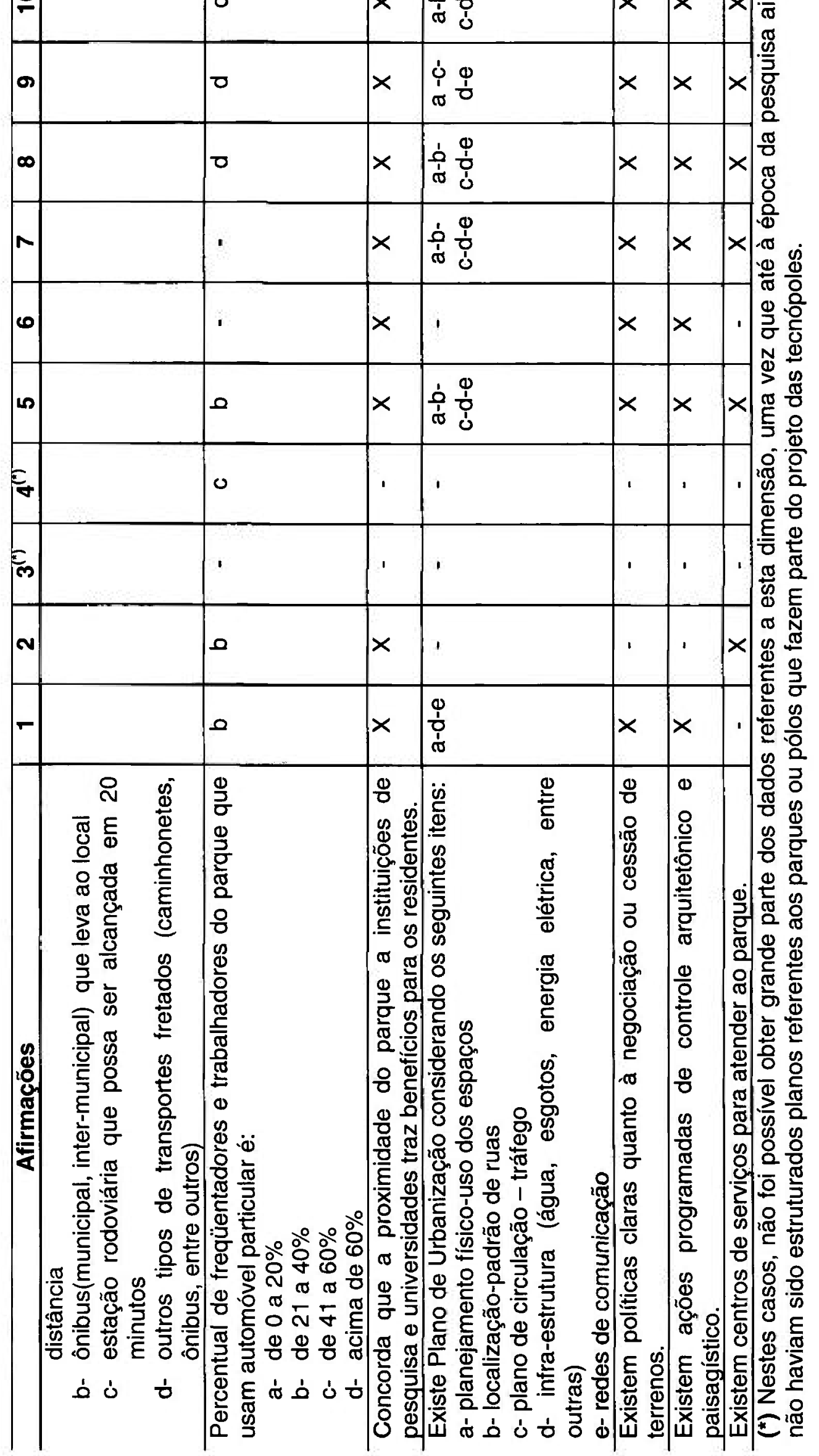




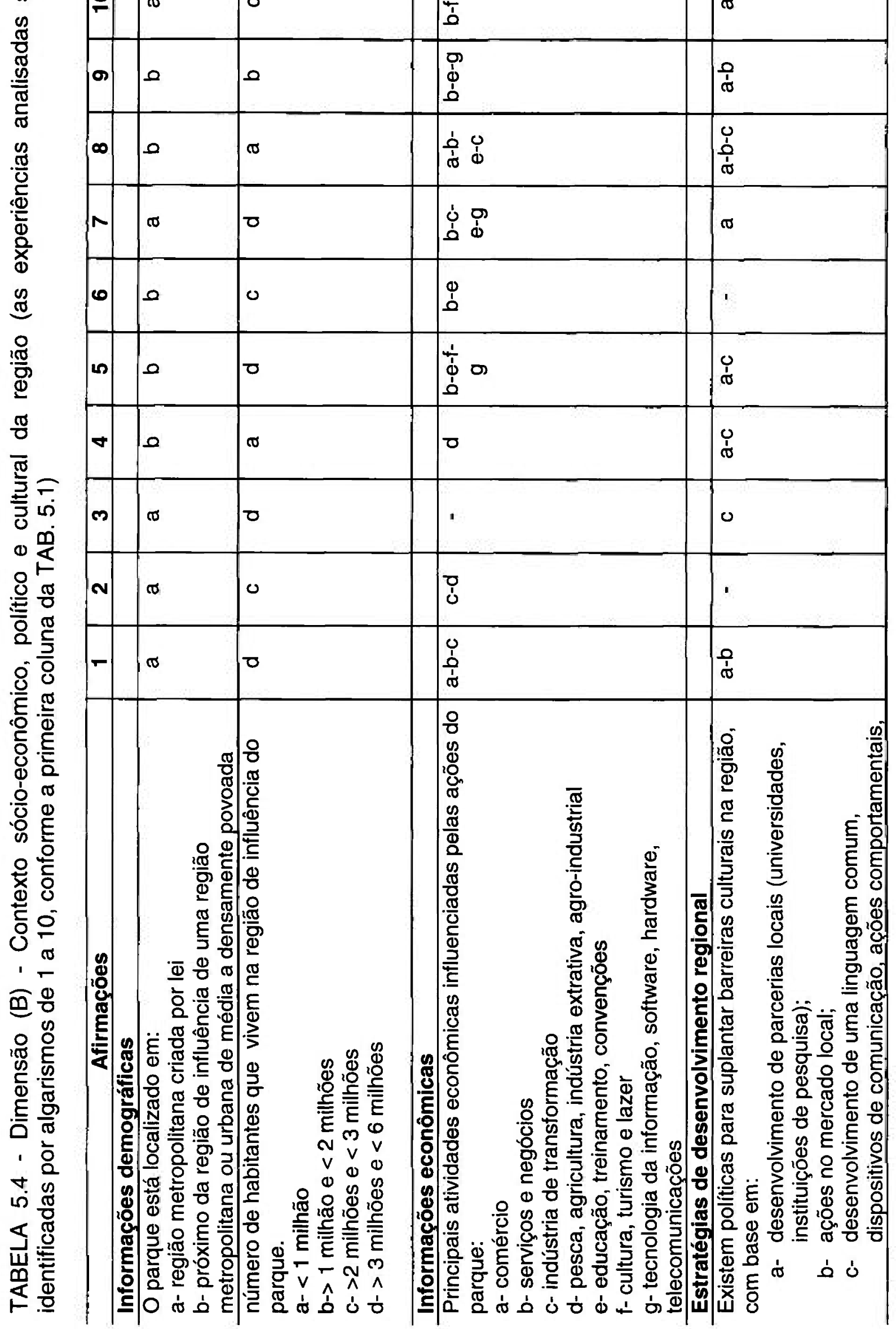




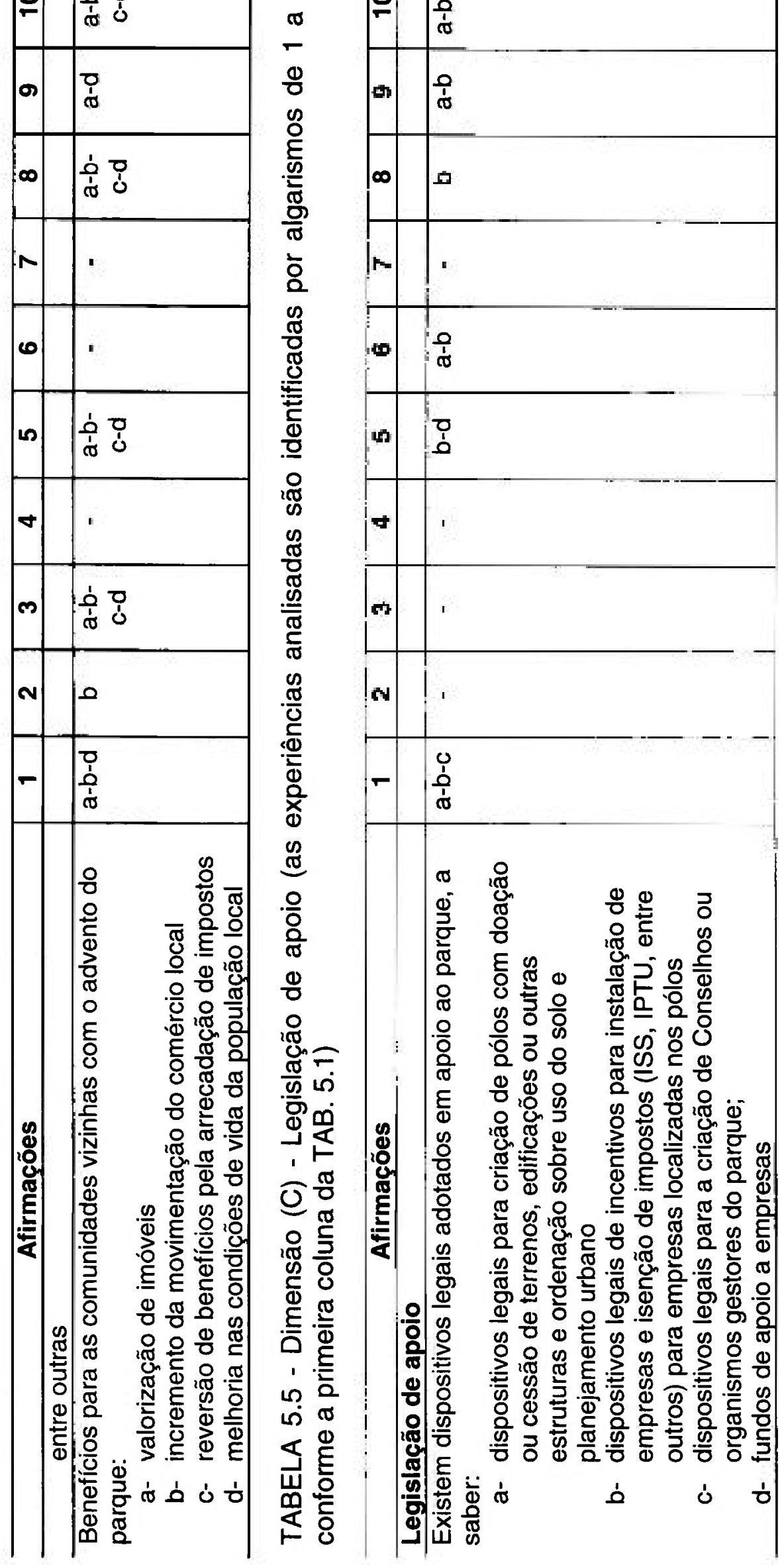




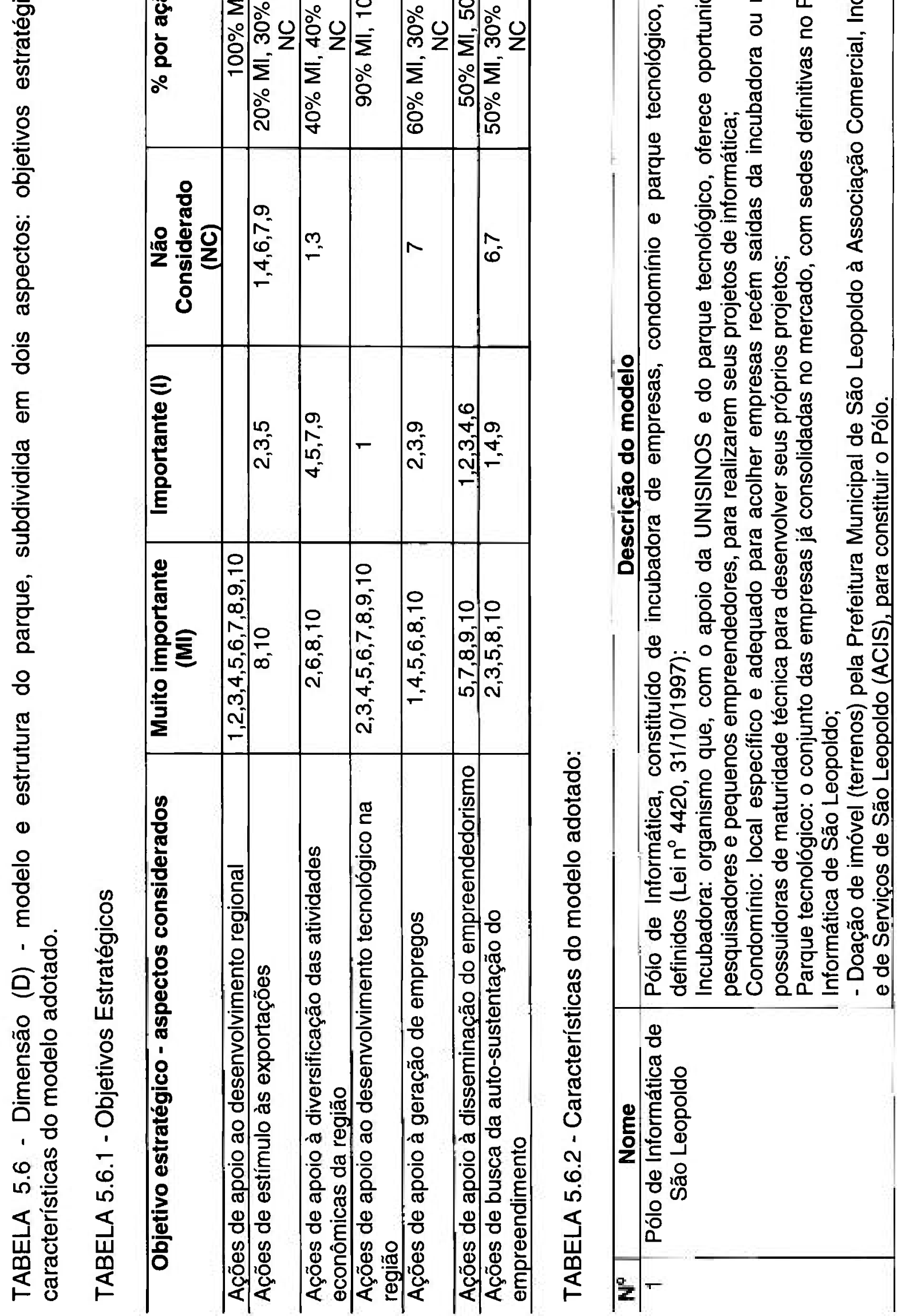




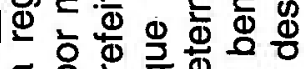

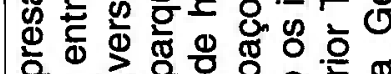

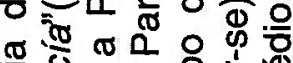

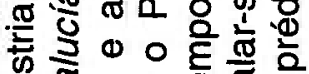

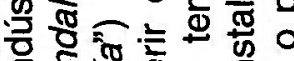
s ₹

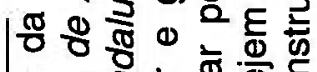

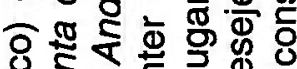

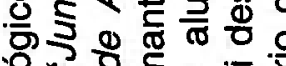

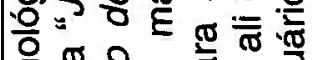
类

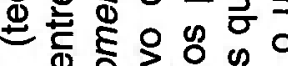

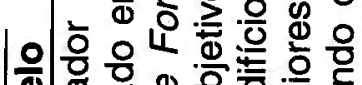

\%)

- E

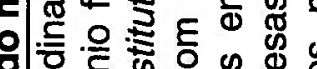
일

용

잉

फे ه.

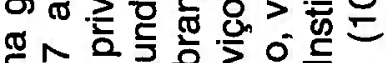

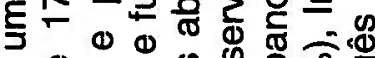

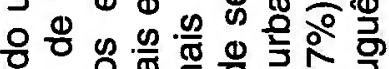

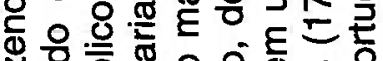

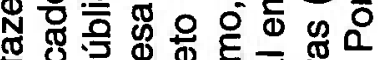

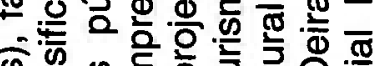
कि \% 政

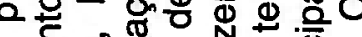

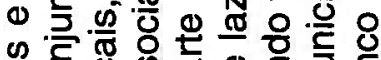

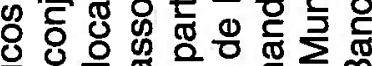

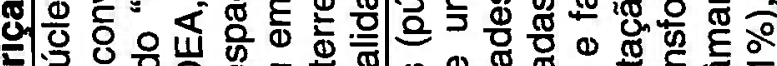

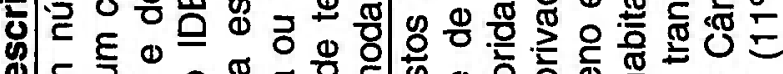
可 等

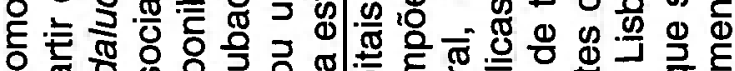

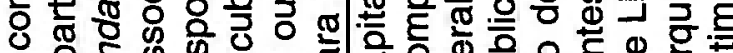

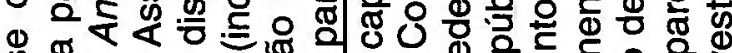
策

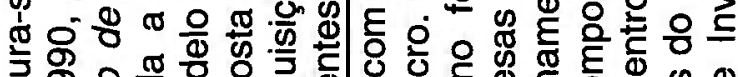

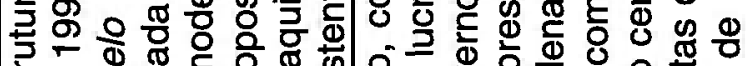

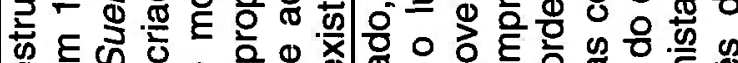
\% 등

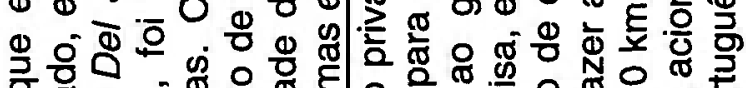
웜

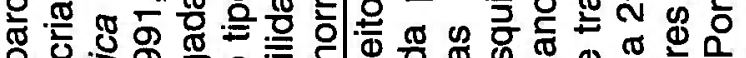

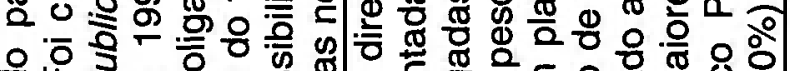

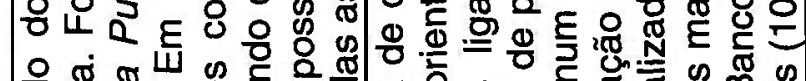

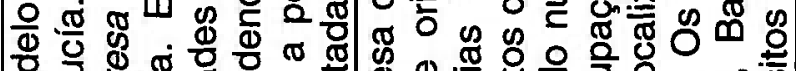

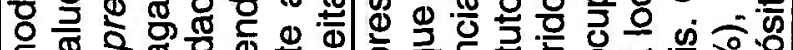

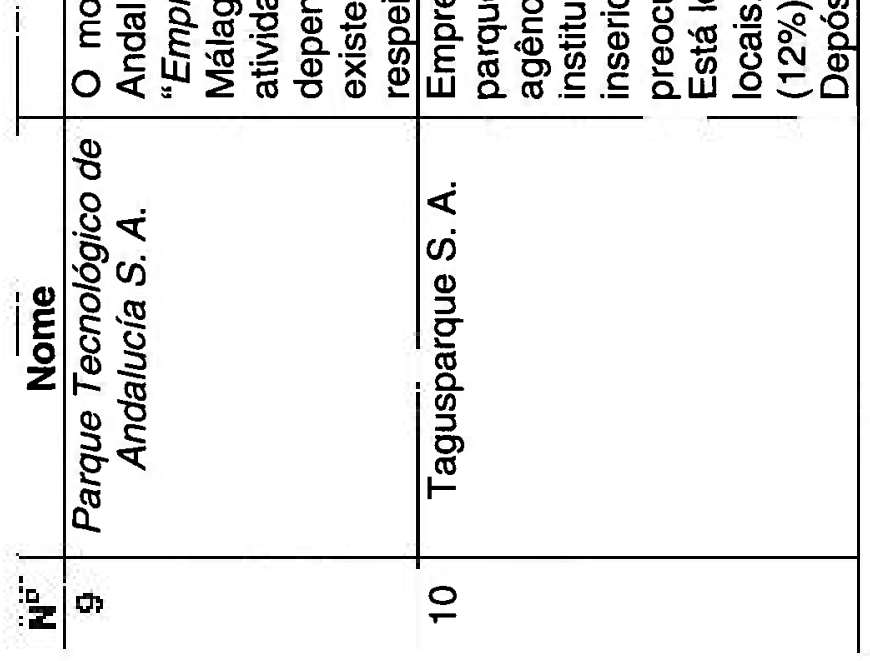

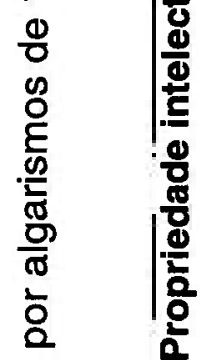

s. $\frac{\alpha}{0}$

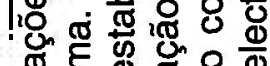

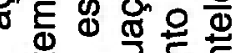

辰 0

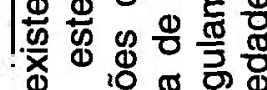

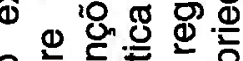

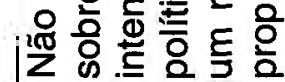

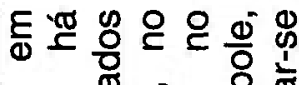

势

政 类。

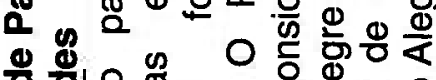

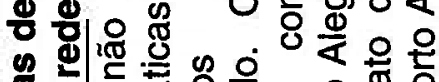

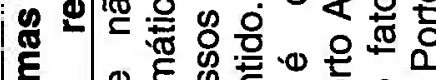
署 은 음

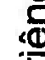

8

d

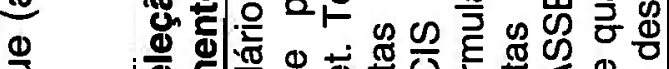

喜

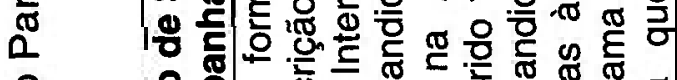

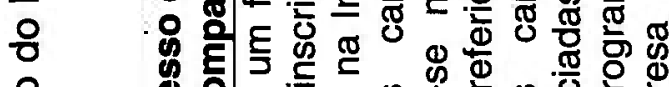

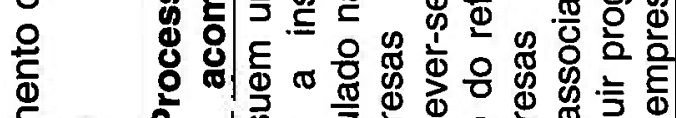

है

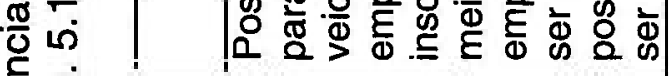

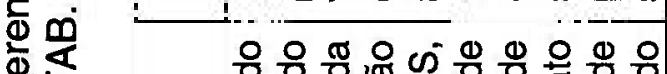

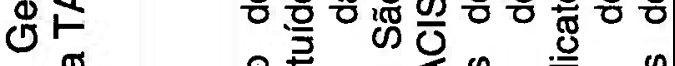

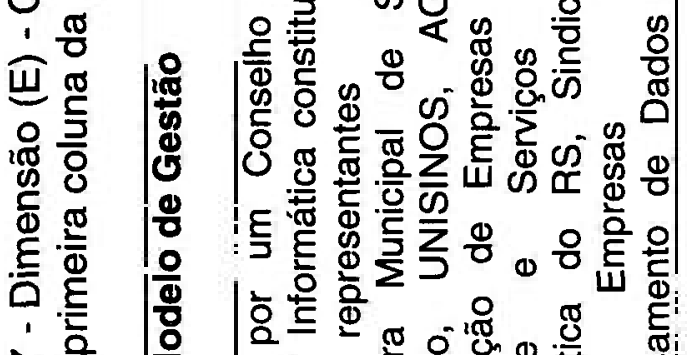

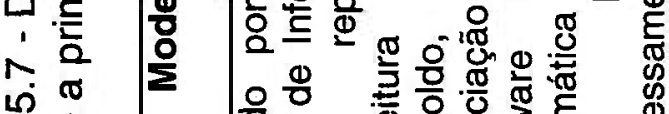

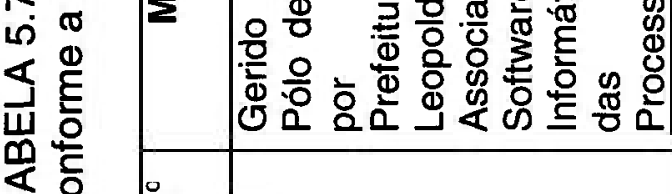

近 


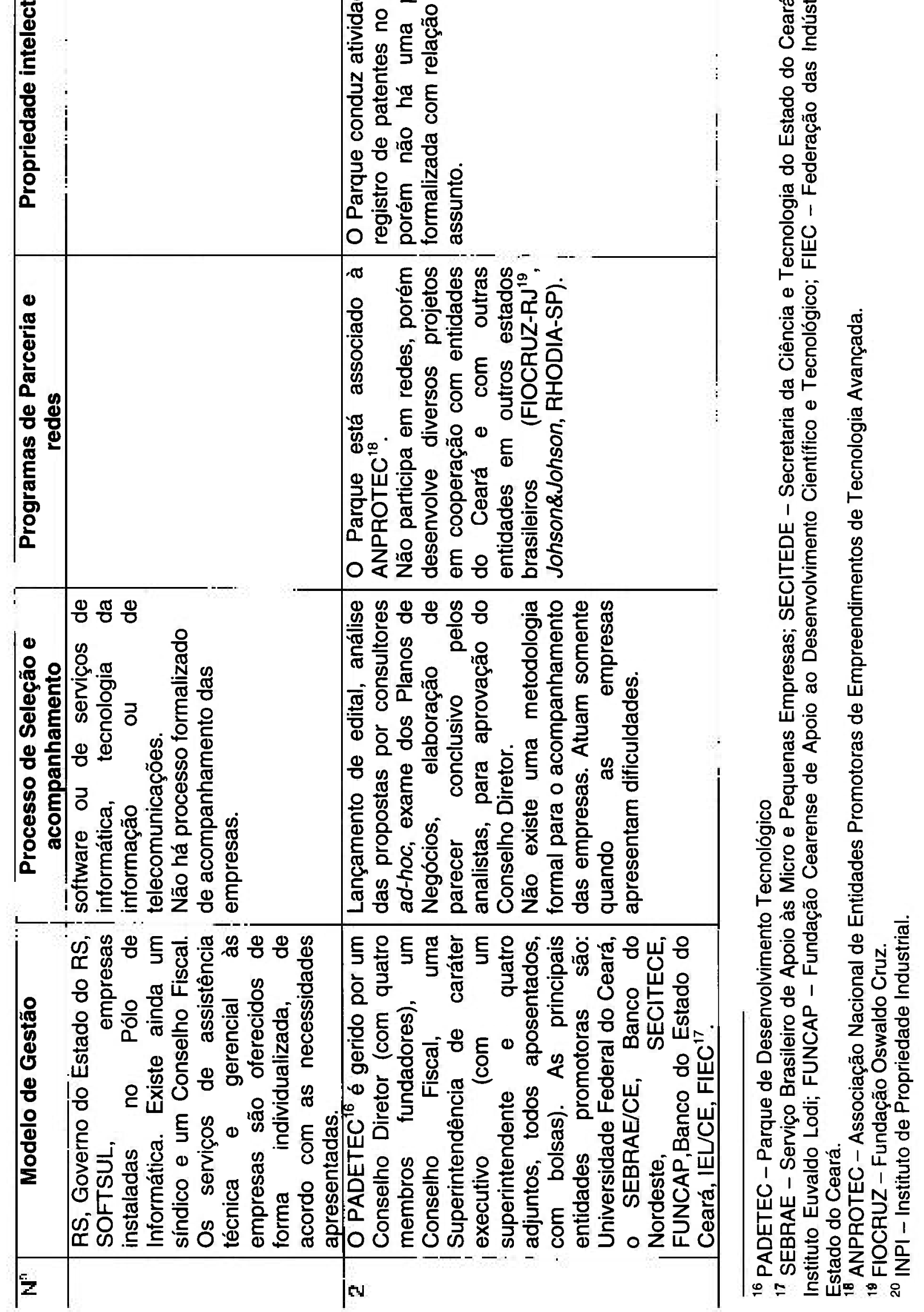




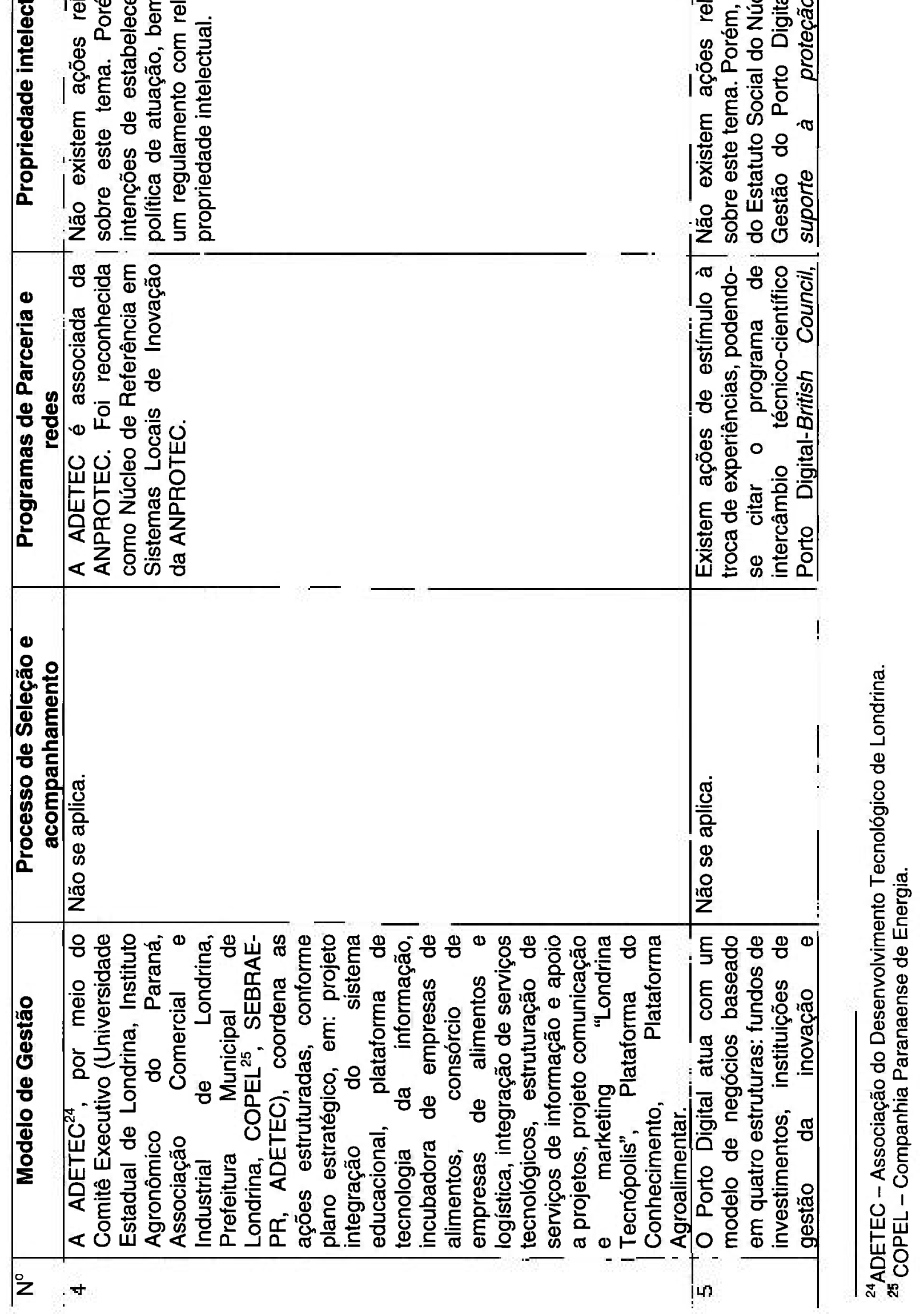




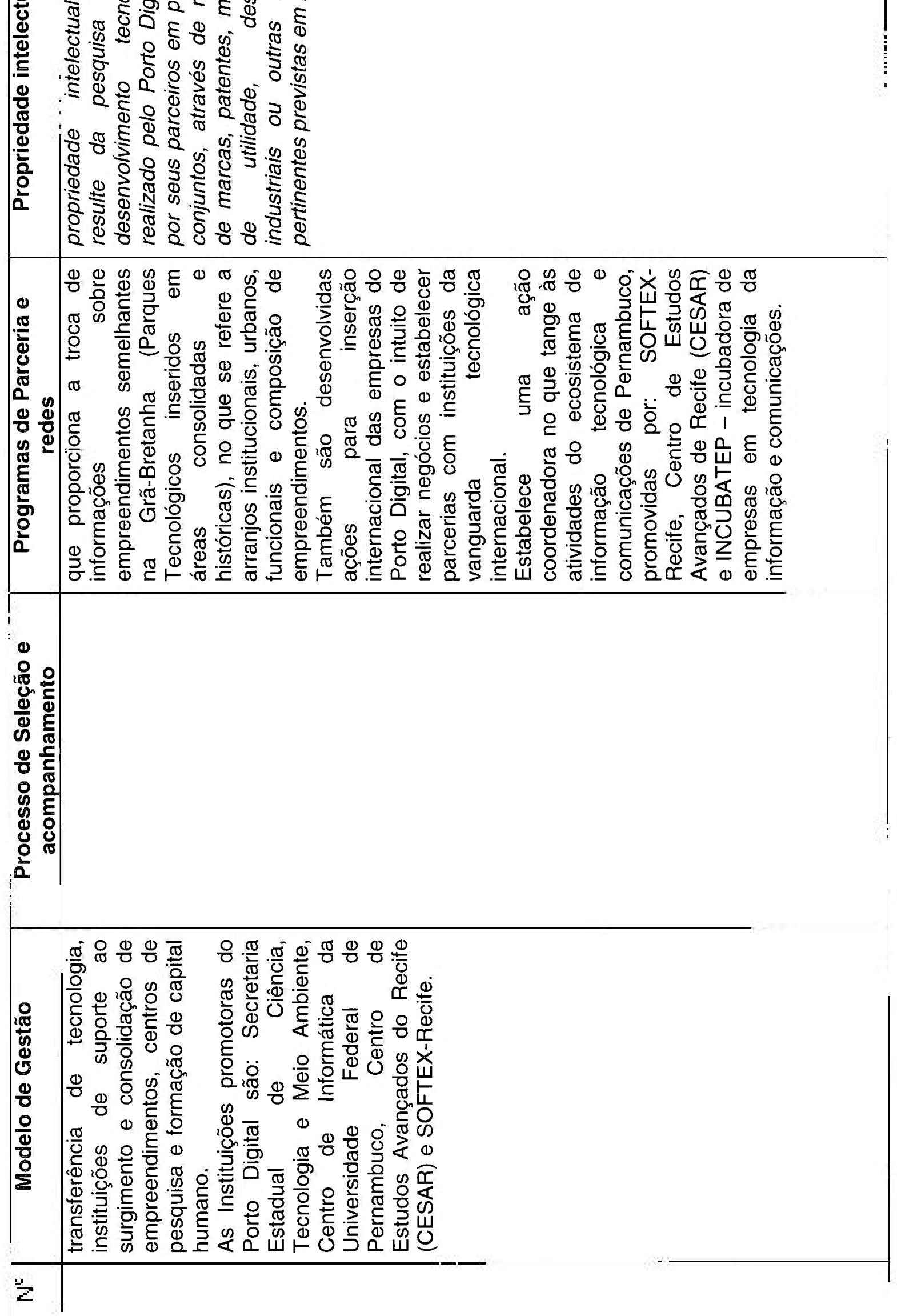




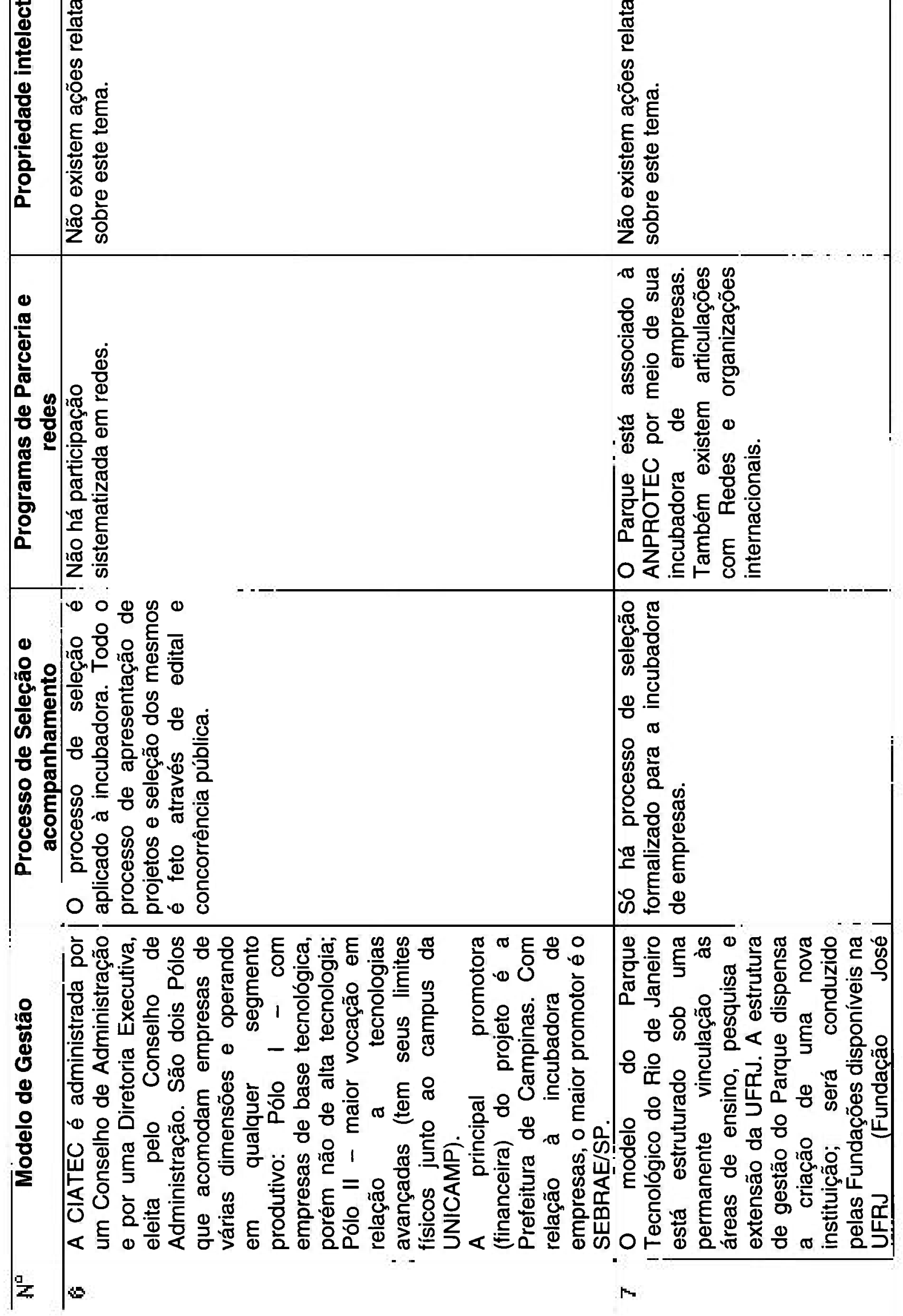




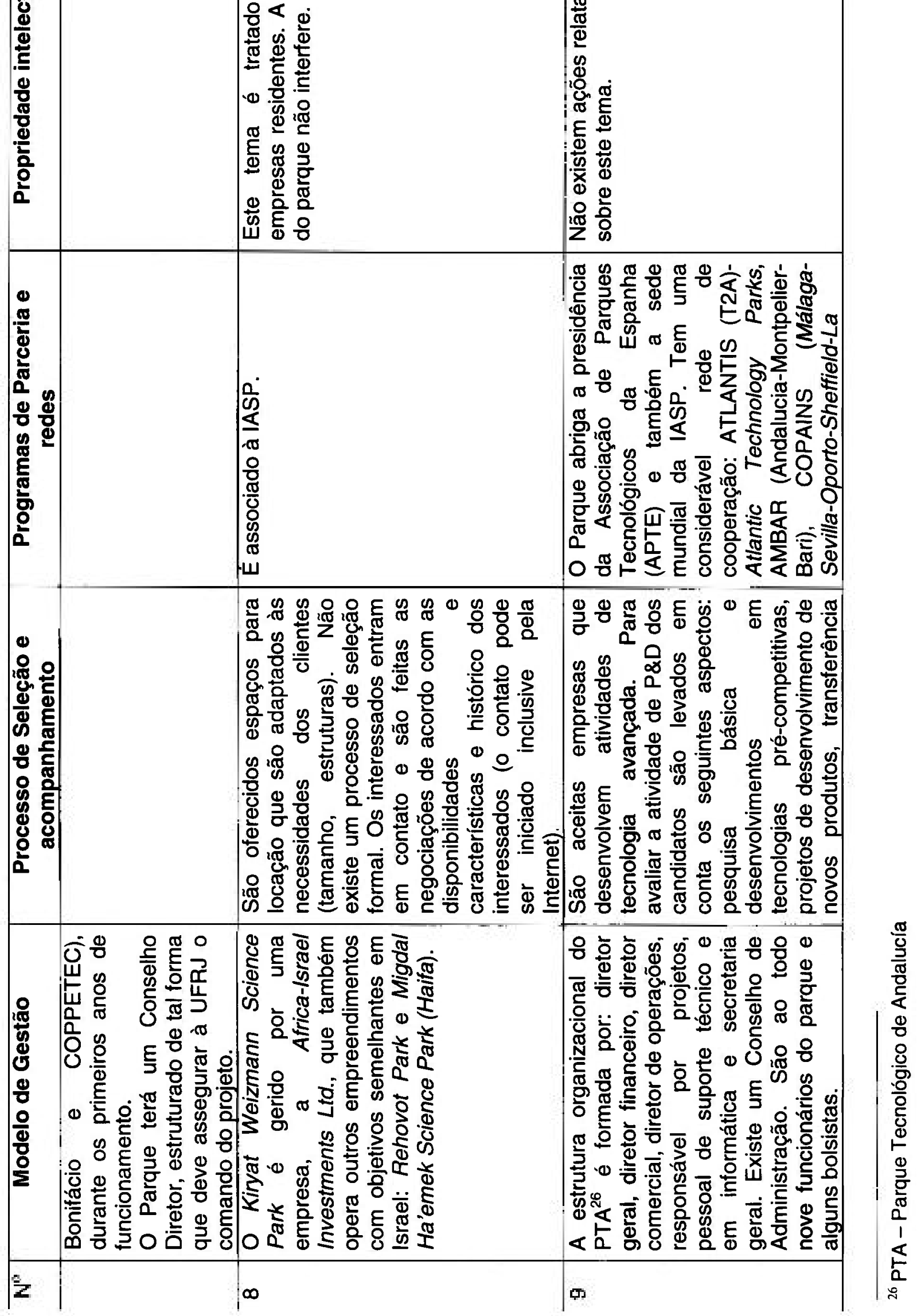




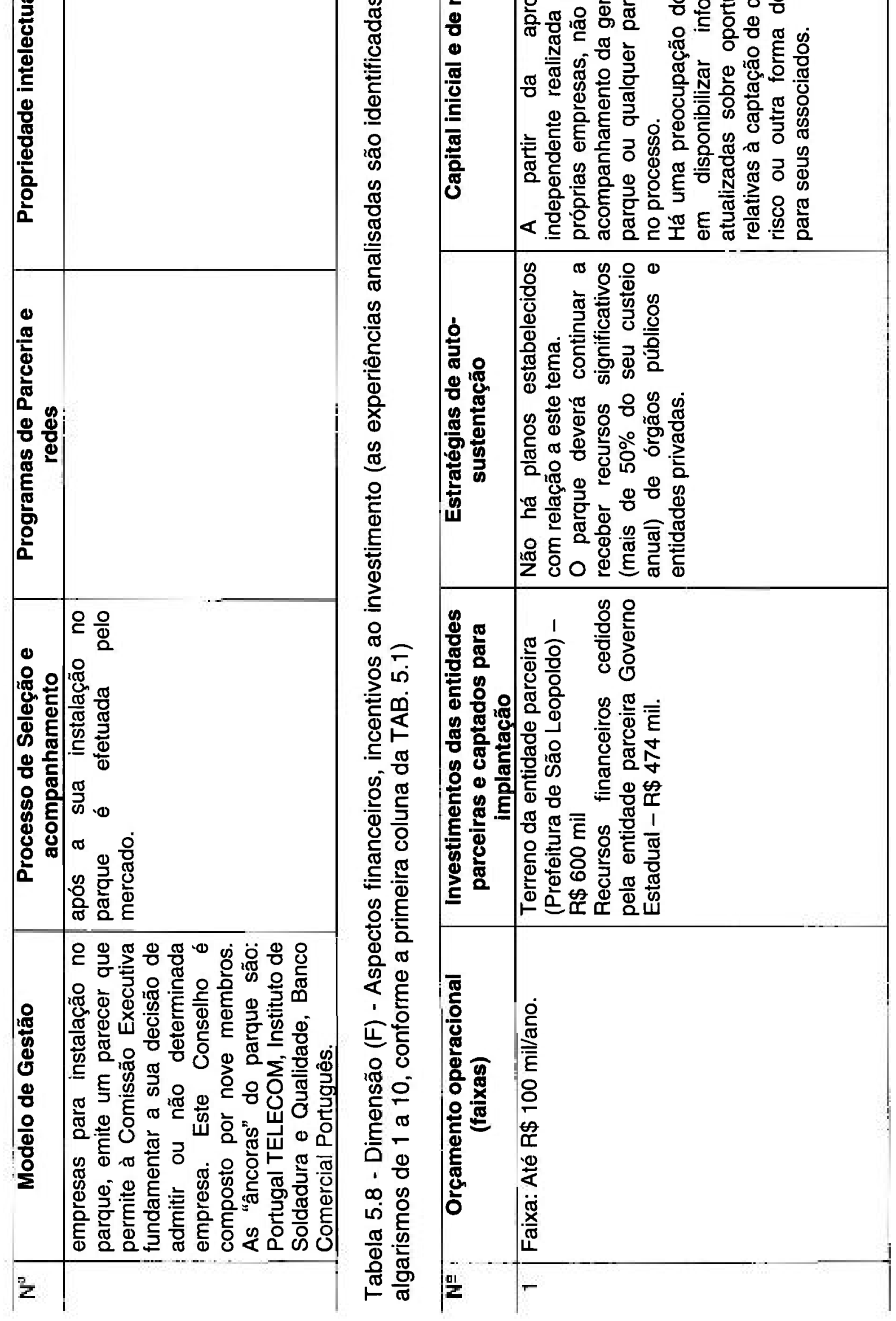




\begin{tabular}{|c|c|c|c|c|}
\hline 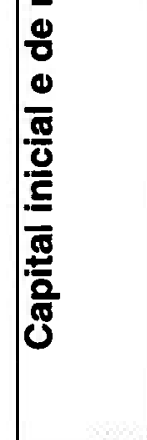 & 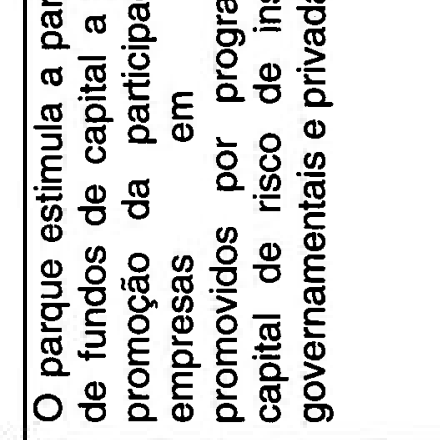 & 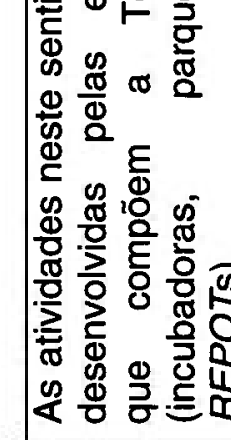 & 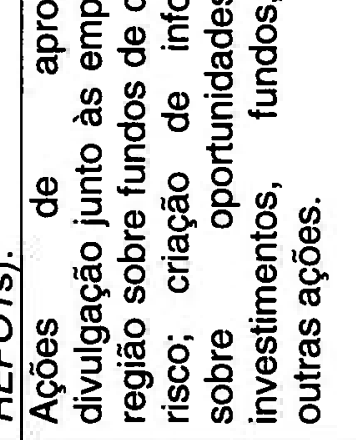 & 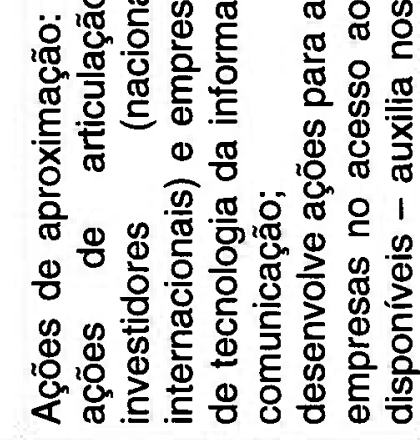 \\
\hline 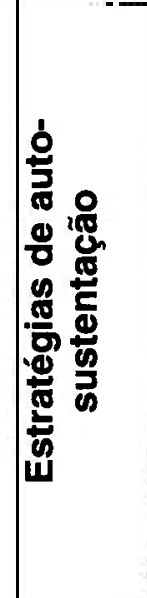 & 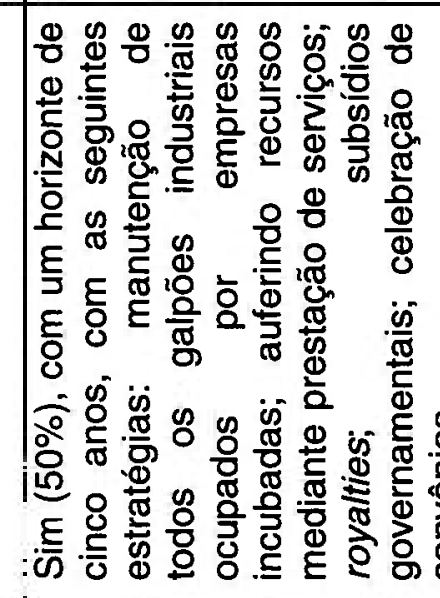 & 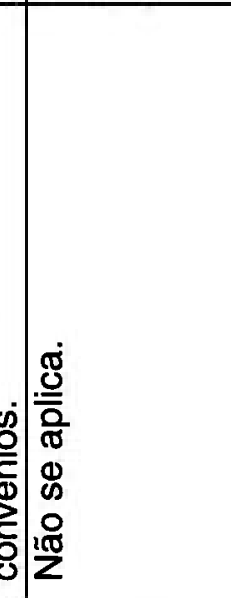 & 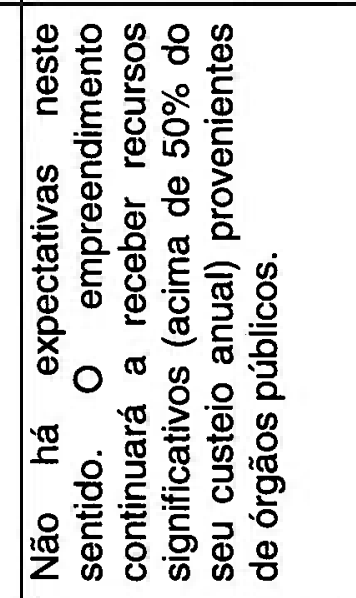 & 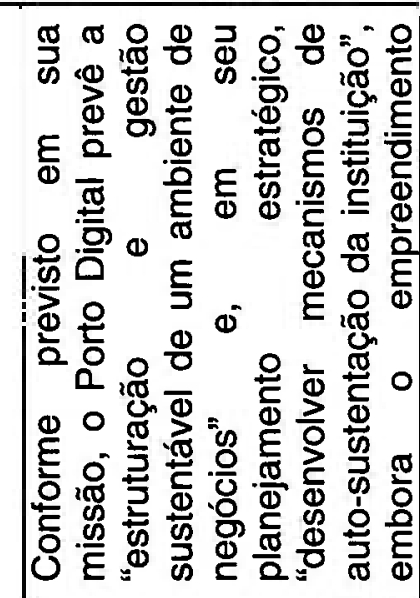 \\
\hline 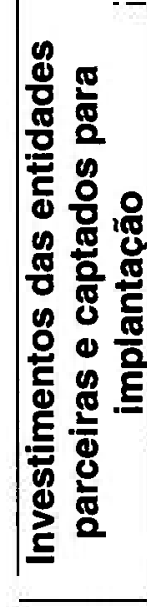 & 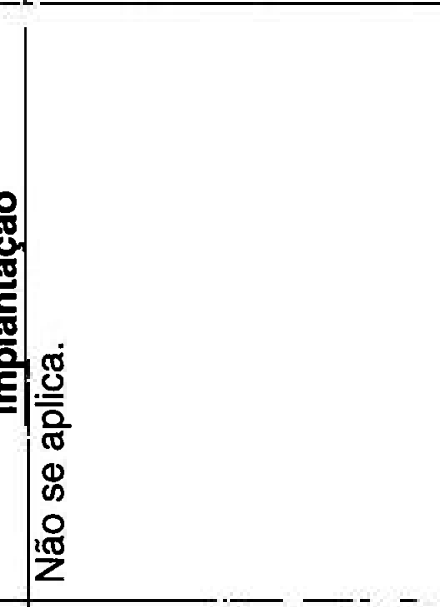 & 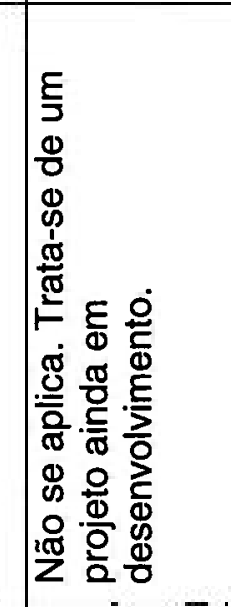 & 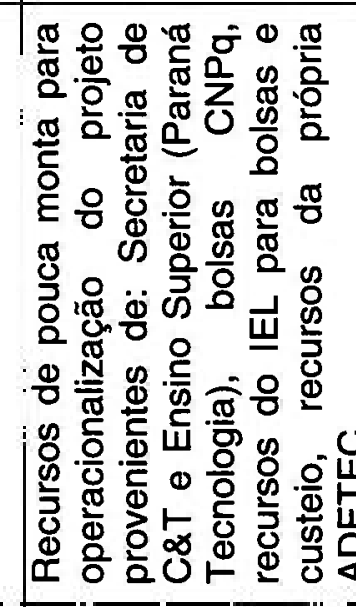 & 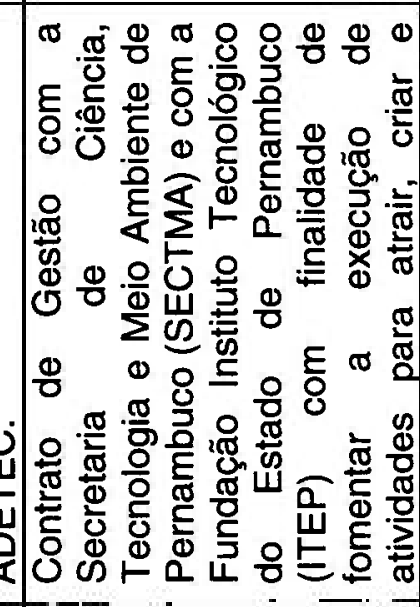 \\
\hline 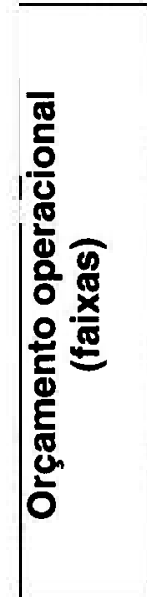 & 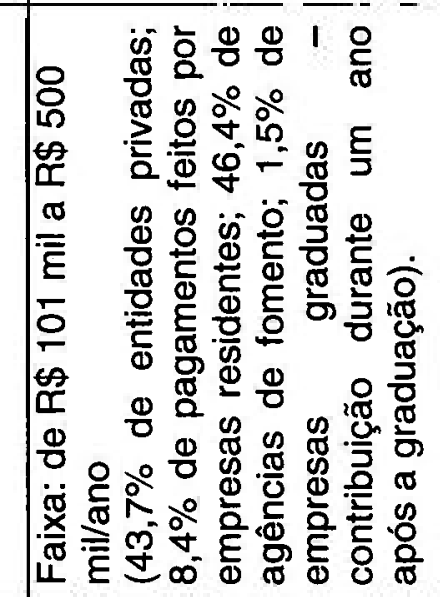 & 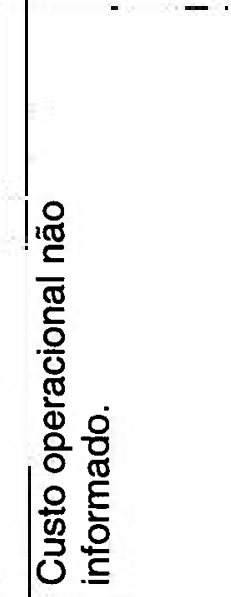 & 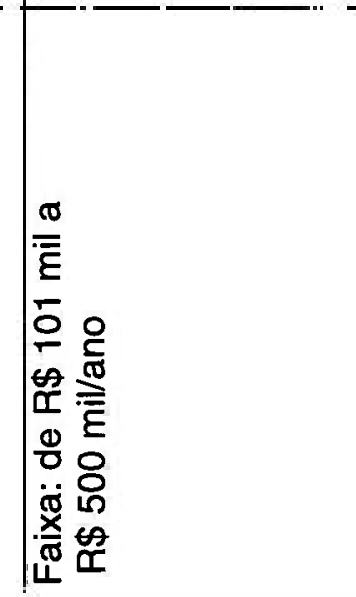 & 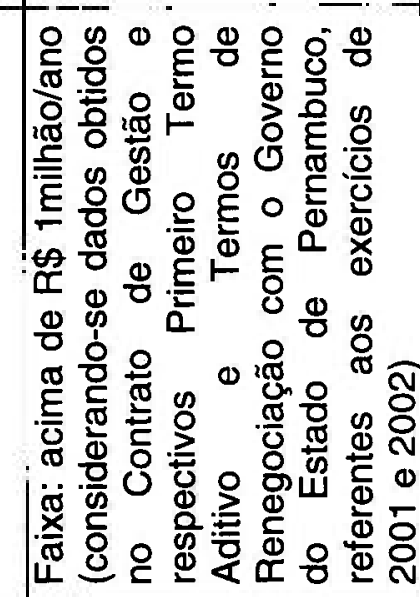 \\
\hline & ev & $m$ & + & in \\
\hline
\end{tabular}




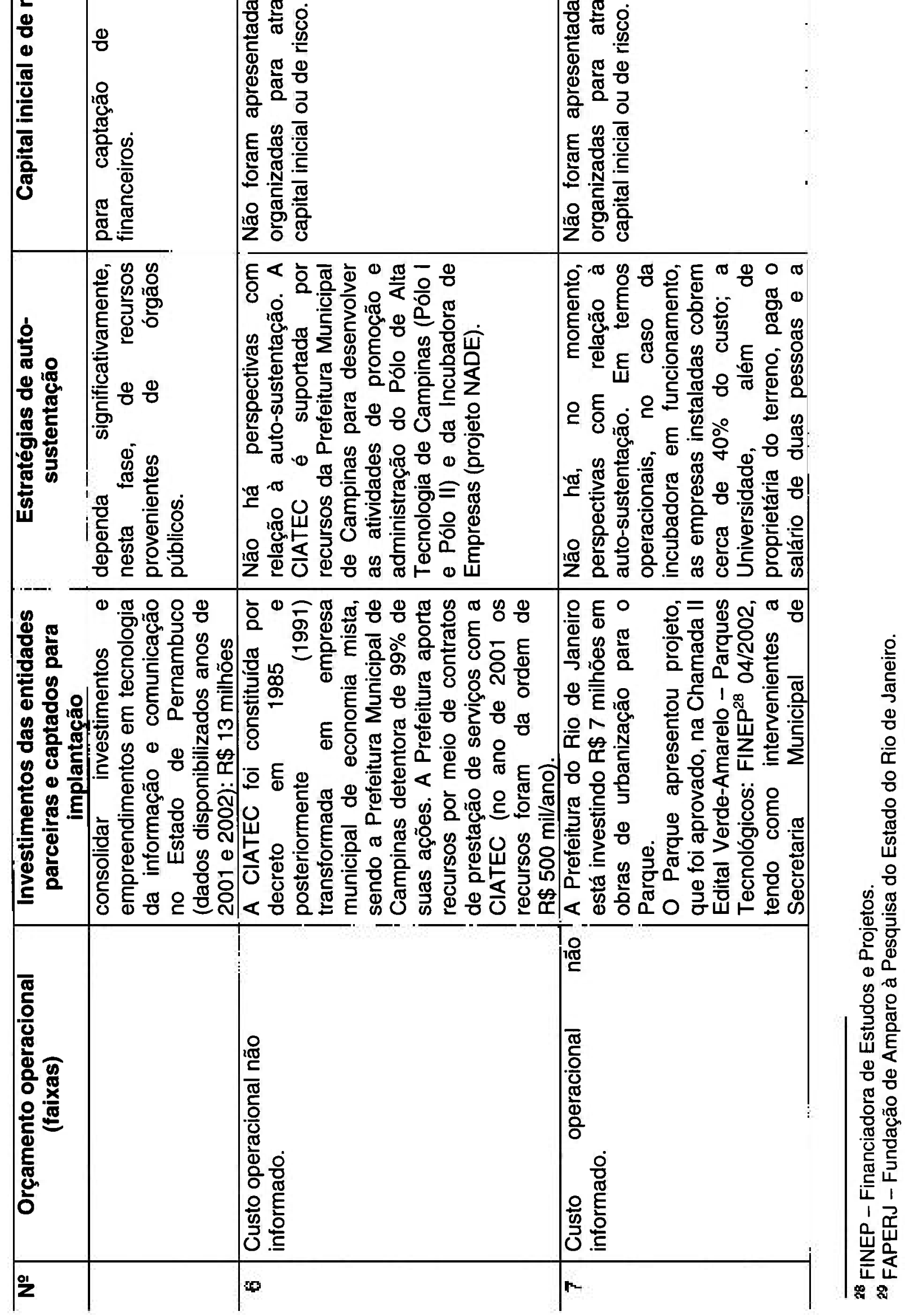




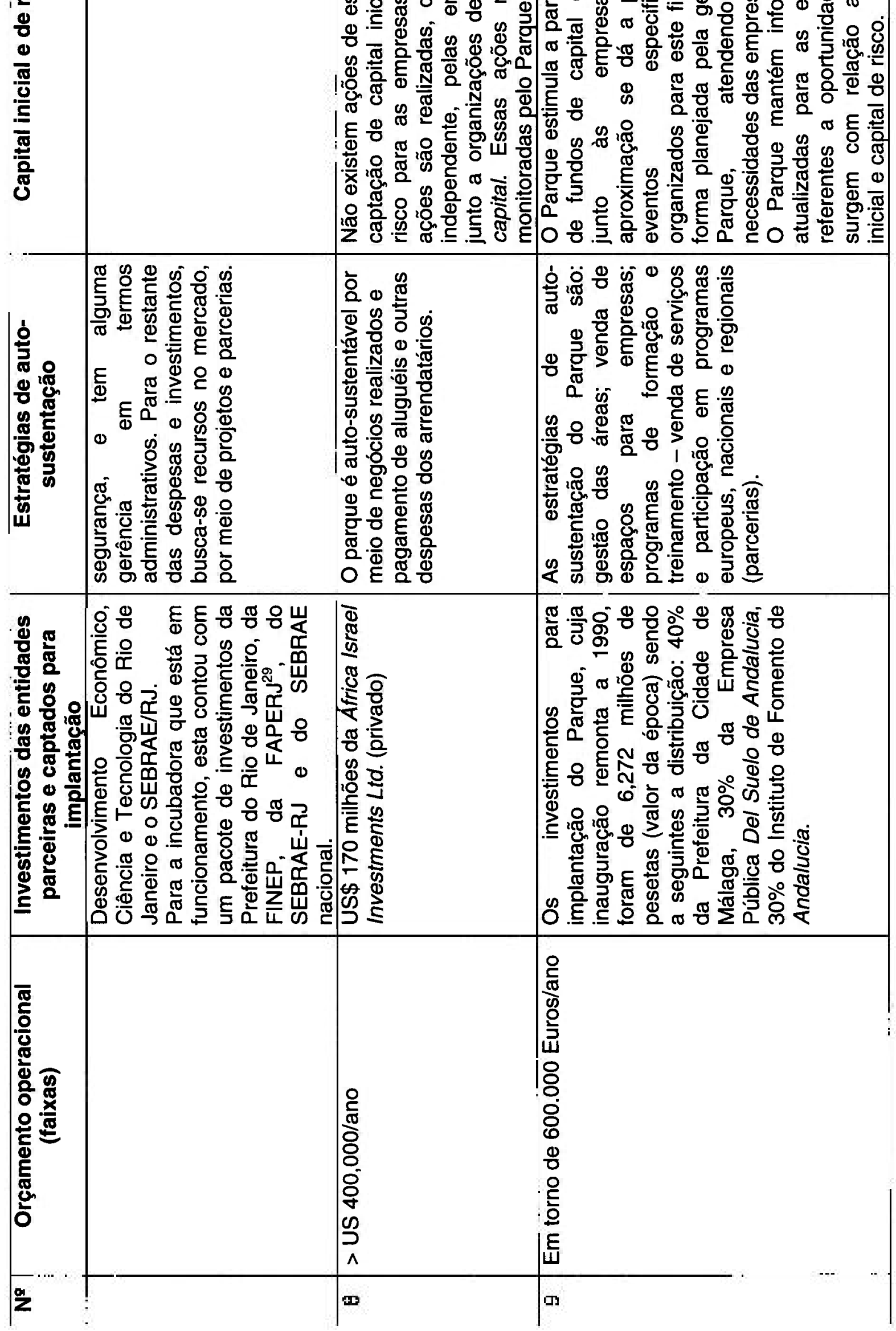




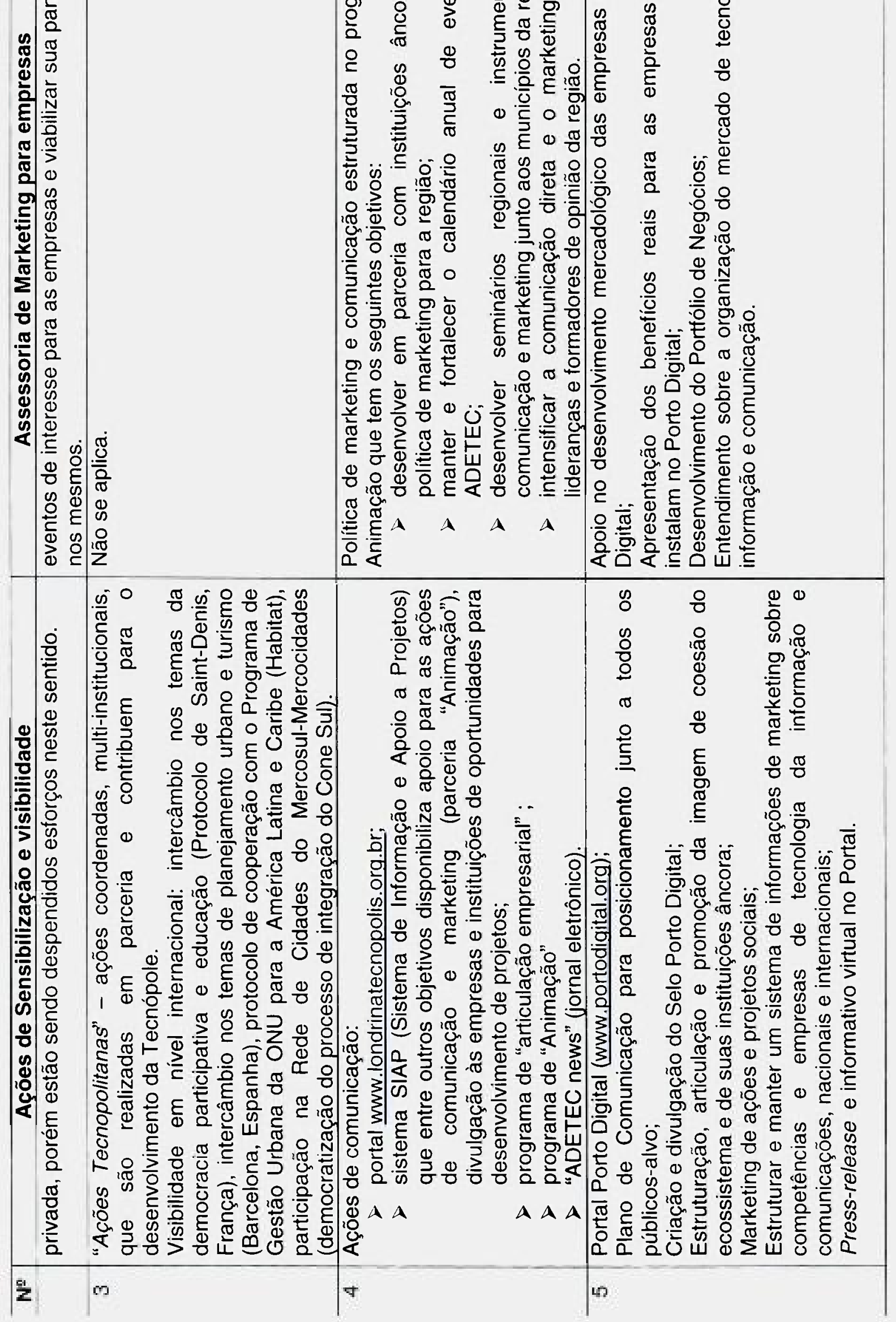




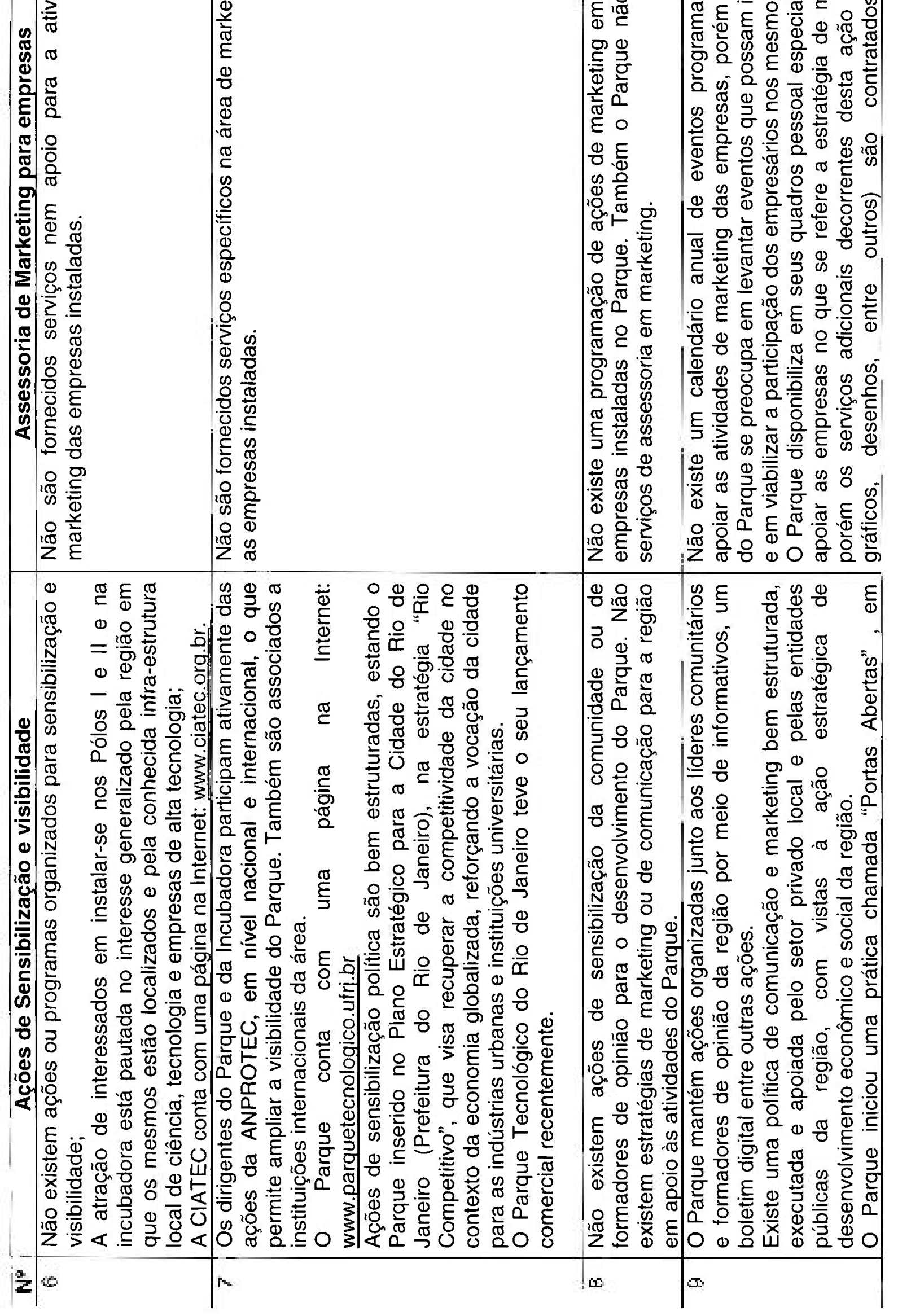




\begin{tabular}{|c|c|c|c|c|c|c|}
\hline 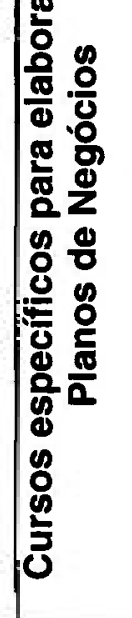 & 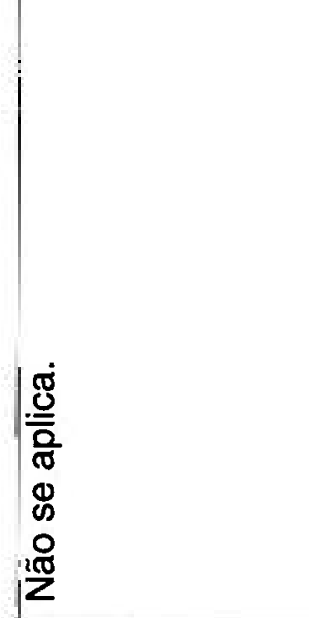 & 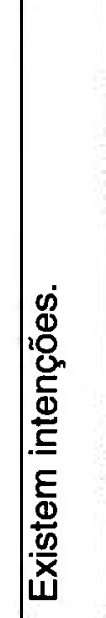 & 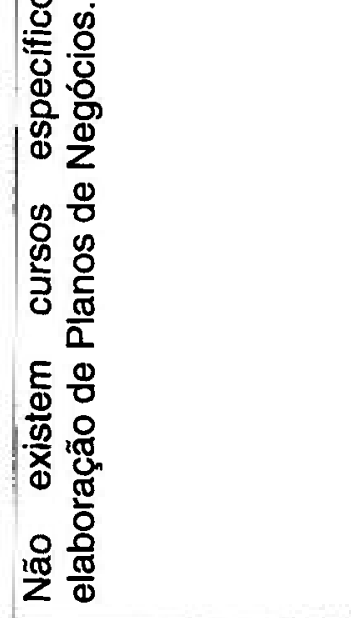 & & 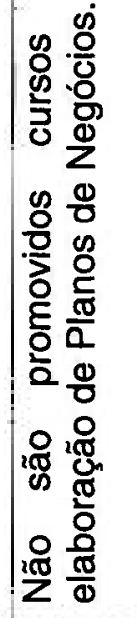 & 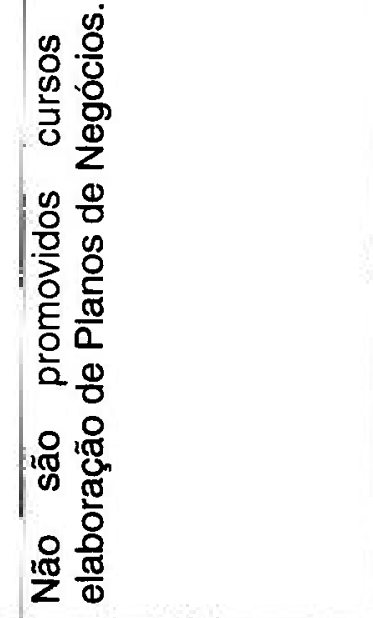 \\
\hline 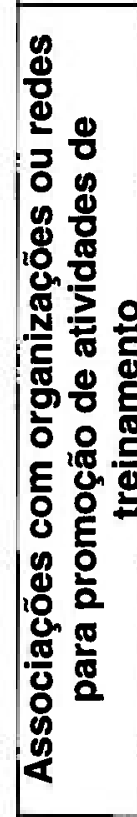 & 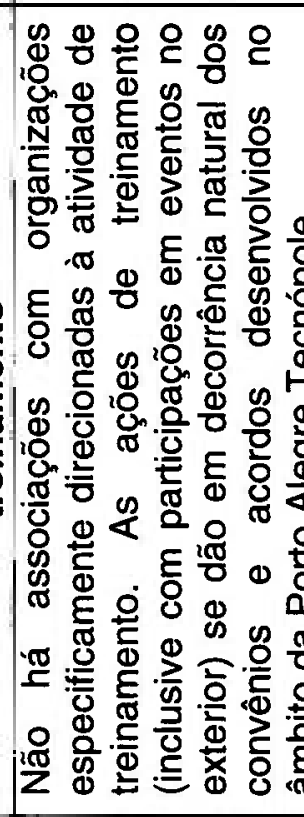 & 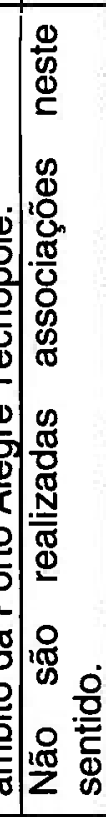 & 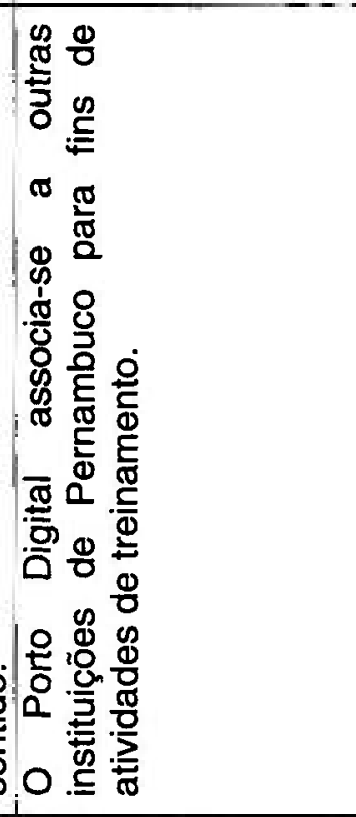 & & 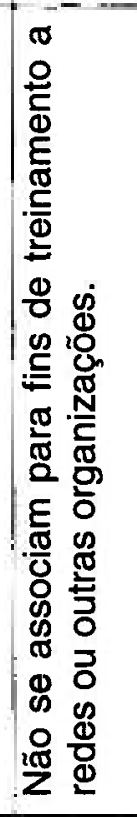 & 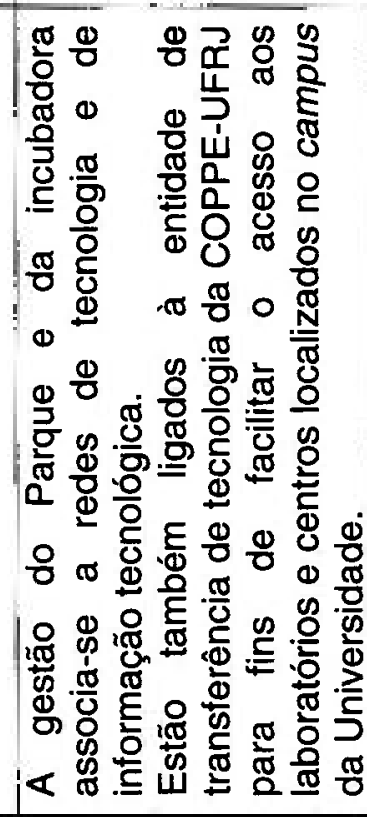 \\
\hline 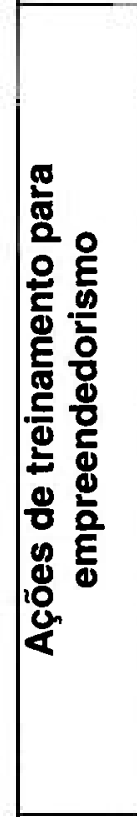 & 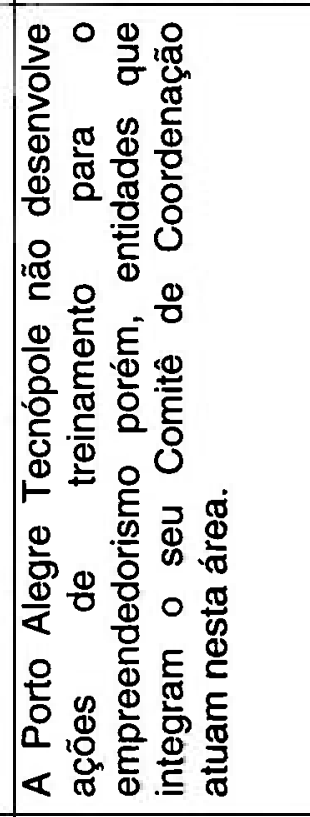 & 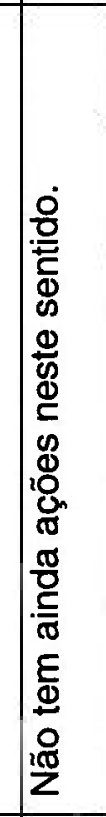 & 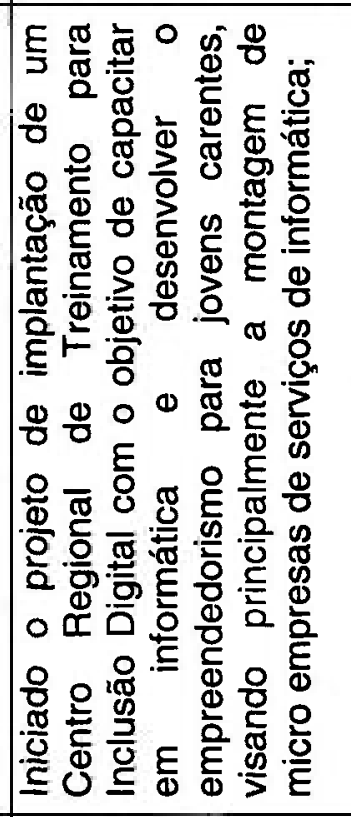 & 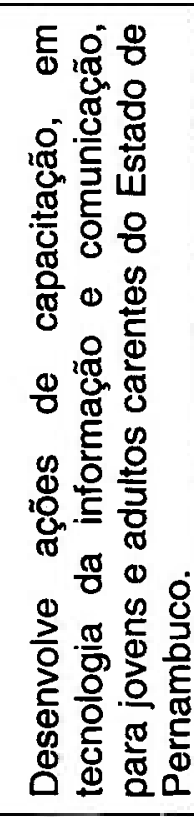 & 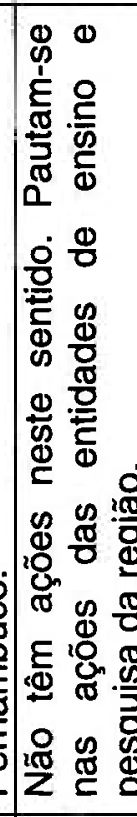 & 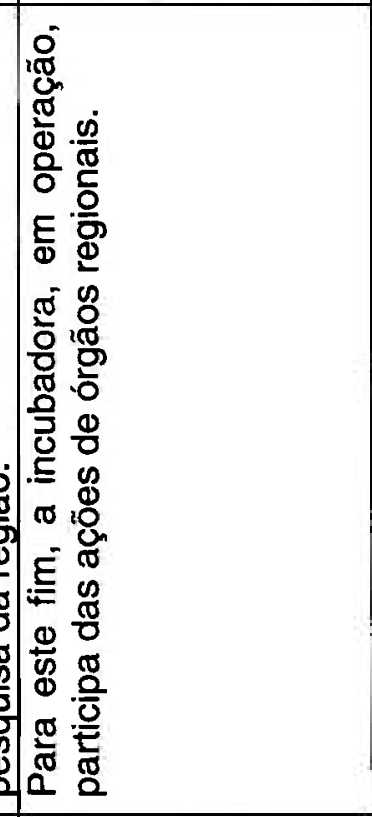 \\
\hline & & A & & & & \\
\hline
\end{tabular}




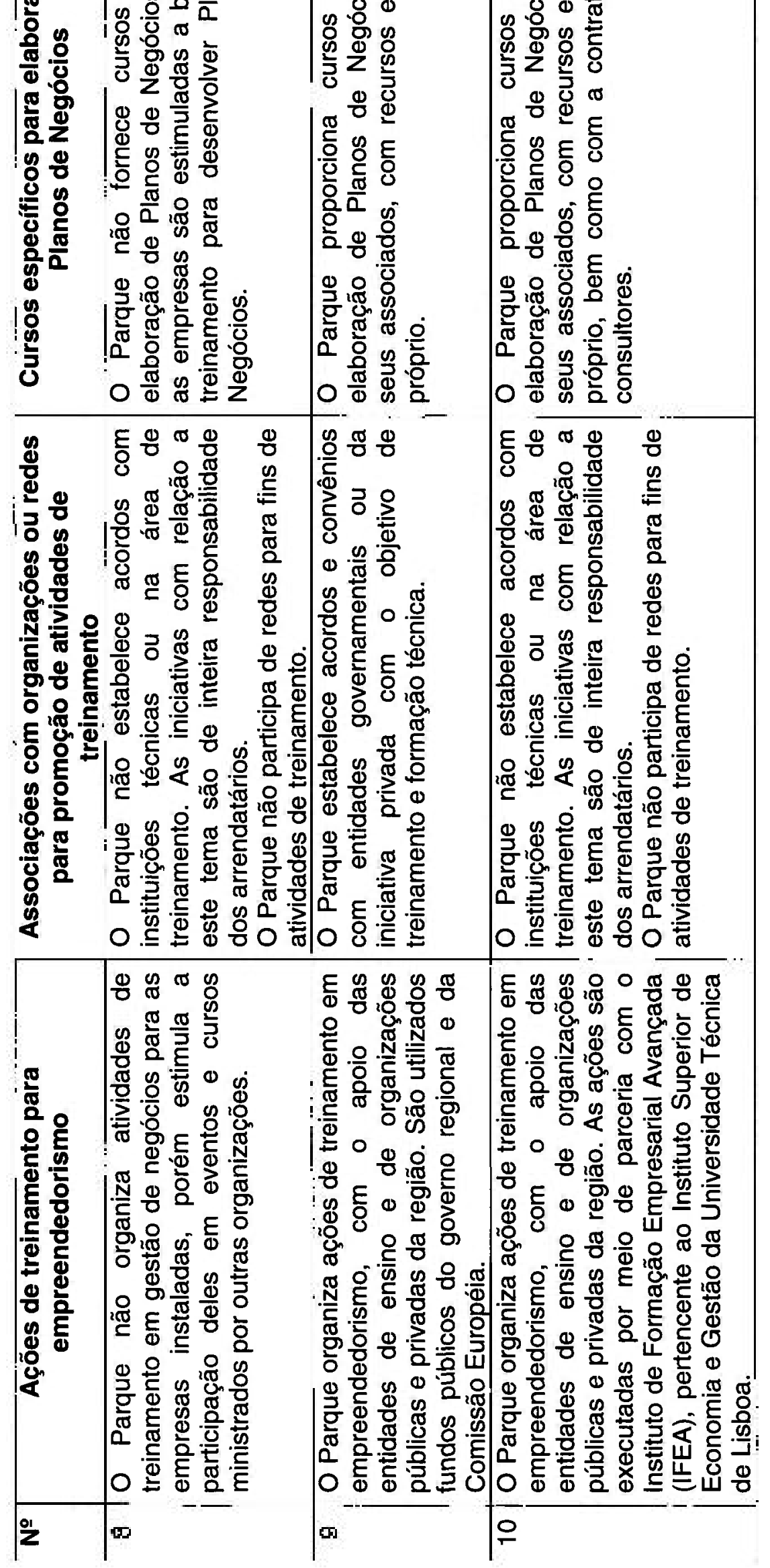




\section{ANÁLISE E DISCUSSÃo DOS RESULTADOS}

A seguir, são apresentadas a análise e discussão dos resultados do capítulo anterior. Para organização dessa análise e discussão o capítulo foi dividido em dois itens, sendo que o primeiro apresenta uma descrição das experiências analisadas, resumindo e ressaltando os principais aspectos de suas atuações, conforme observado durante a pesquisa de campo e respectivas entrevistas. No segundo item, são introduzidas duas tabelas que apresentam, de forma sucinta, os aspectos conclusivos e interpretação e comentários sobre a pesquisa de campo.

\subsection{Caracterização das experiências analisadas}

\subsubsection{Pólo de Informática de São Leopoldo}

As articulações na região de São Leopoldo para a criação do Pólo de Informática iniciaram-se em 1996, por iniciativa da Associação Comercial e Industrial de São Leopoldo que atraíram a Prefeitura do Município e a Universidade do Vale do Rio dos Sinos - UNISINOS. A forte participação da UNISINOS no processo está caracterizada por sua integração com a comunidade da região, principalmente com o meio empresarial, por meio de programas permanentes. A UNISINOS é também uma das entidades instituidoras do "Movimento Viva São Leopoldo" que consiste num fórum de discussões das necessidades e de busca de soluções para a promoção do desenvolvimento econômico, social e cultural do município.

O Pólo de Informática de São Leopoldo foi criado por meio da Lei Municipal no 4420, de 31 de outubro de 1997, com uma estrutura que prevê uma incubadora, um condomínio e o parque tecnológico. Essa Lei foi resultado da articulação de diversos atores entre eles: a UNISINOS, a Prefeitura Municipal de São Leopoldo, o Governo do Estado do Rio Grande do Sul, a Associação Comercial e Industrial de São Leopoldo - ACIS, a Associação das Empresas de Software e Serviços de Informática do Rio Grande do Sul - ASSEPRO, e o SOFTSUL (escritório do Programa SOFTEX no Rio Grande do Sul), cujos representantes tinham reuniões semanais. Foi definida uma nomenclatura para identificar as seguintes estruturas: 
“Parágrafo Ủnico - Para os fins desta Lei, considera-se:

I - incubadora: organismo que, com o apoio da Universidade do Vale do Rio dos Sinos - UNISINOS e do parque tecnológico, oferece oportunidade a pesquisadores e pequenos desenvolvedores, para realizarem seus projetos de informática;

II - condomínio: local específico e adequado para acolher empresas recém saídas da incubadora ou não, já possuidoras de maturidade técnica, para desenvolver seus próprios projetos;

III - parque tecnológico: o conjunto das empresas já consolidadas no mercado, com sedes definitivas no Pólo de Informática".

Também por intermédio dessa Lei, a Prefeitura foi autorizada a doar terras $\left(90 \%\right.$ de uma área de terras com um total de $\left.36.589,29 \mathrm{~m}^{2}\right)$ para a ACIS para nelas constituir o Pólo de Informática de São Leopoldo e criou o Conselho do Pólo de Informática com um representante de cada parceiro (Prefeitura Municipal de São Leopoldo, UNISINOS, ACIS, ASSESPRO, Sindicato das Empresas de Processamento de Dados do Rio Grande do Sul - SEPRORS, Governo do Estado do Rio Grande do Sul, SOFTSUL - parte do Programa Federal do SOFTEX 2000 e um representante das empresas instaladas no Pólo).

Em decorrência do comprometimento do poder público com o empreendimento além da Lei de criação do Pólo, foi promulgada a Lei Municipal $n^{\circ} 4368$, de 05 de maio de 1997, que altera 0 artigo $1^{\circ}$ da Lei Municipal $n^{\circ} 3874$, de 05 de agosto de 1993 que, por sua vez, concede isenção de Imposto Sobre Serviços de Qualquer Natureza - ISSQN e Imposto Predial e Territorial Urbano IPTU a empresas de informática, a saber:

"Art. $1^{0}$ Às empresas estabelecidas ou que vierem a estabelecerse no Município de São Leopoldo, com atividades de informática, comunicação de dados, automação, micro-mecânica, é concedida isenção de imposto sobre serviços de qualquer natureza - ISSQN, e imposto predial e territorial urbano - IPTU sobre os imóveis que efetivamente utilizam para suas atividades, até 31 de dezembro de 2003. A partir desta data a carga tributária será de 1\%."

$\mathrm{Na}$ prática, a concepção do modelo estabelece uma Unidade de Desenvolvimento Tecnológico (UNITEC) e o Parque Tecnológico. A UNITEC é de propriedade da UNISINOS, estando vinculada ao Centro de Ciências Exatas e Tecnológicas da Universidade, e compreende uma incubadora empresarial e um sistema de condomínio de empresas. A incubadora abriga novas empresas e produtos, enquanto que 0 condomínio recebe empresas constituídas na 
incubadora, ou não, que já estejam em condições de comercializar seus produtos. Além de espaço físico e infra-estrutura de serviços básicos, a Universidade apóia a UNITEC por meio do oferecimento de serviços científicos e técnico-profissionais especializados, tendo inclusive firmado parceria com o SEBRAE/RS para apoiar as microempresas instaladas na UNITEC.

O prédio da incubadorà tem um projeto arquitetônico integrado ao ambiente da Universidade, tendo sido contratado e executado com recursos da UNISINOS. São 44 módulos de $25 \mathrm{~m}^{2}$, porém a gerência quer ter no máximo 25 empresas instaladas. Atualmente, são nove empresas incubadas.

Na fase inicial, para captação de interesse para o empreendimento, foi aberta uma lista de adesão ao Pólo, mais especificamente para a incubadora de empresas, sendo que a seleção baseou-se na busca por empresas que tivessem produtos inovadores em termos de mercado (não estimulavam, a princípio, a adesão de empresas de serviços). Nessa chamada, quatorze empresas inscreveram-se. Desde o início da instalação da incubadora de empresas do Pólo, houve uma grande interação com a UNISINOS de tal forma que, de acordo com o depoimento de seu gerente durante a entrevista, "o que mantém os projetos não é a isenção de impostos, mas sim essa interação".

O Parque Tecnológico está localizado em área da Prefeitura, em frente ao prédio da incubadora (Avenida Theodomiro Porto da Fonseca, 3101, bairro de Duque de Caxias, em São Leopoldo). O Parque foi concebido com o intuito de abrigar empresas que desenvolvem software e que prestam serviços na área de informática, que estejam já consolidadas em termos de mercado. Estando as empresas já no mercado, o modelo do Parque busca qualificar e apoiar a ampliação das atividades dessas empresas, em busca de novas tecnologias, utilizando-se para isso da proximidade física com os laboratórios e instalações da Universidade. Atualmente, encontram-se instaladas dez empresas que foram atraídas para a região. A Prefeitura é dona do terreno e as empresas que se instalam pagam pelo terreno em dez anos, com pagamentos mensais que são revertidos para o Fundo de Saúde do Município de São Leopoldo (os recursos são aplicados no Hospital Municipal).

É importante ressaltar, nesta experiência, que os benefícios advindos da instalação do Pólo começam a ser reconhecidos pela comunidade local. Em 
2000, foi feita uma pesquisa no município que colocou o Pólo em primeiro lugar em termos de importância de políticas públicas.

À semelhança de outras experiências analisadas, foram utilizados modelos internacionais como referência, neste caso, modelos franceses, espanhóis e portugueses. A UNISINOS faz parte da rede AUSJAL (Rede de Cooperação das Universidades Jesuitas para as Américas) que grande contribuição tem trazido ao Pólo e às relações universidade-empresa local.

\subsubsection{Parque de Desenvolvimento Tecnológico - PADETEC}

O Parque de Desenvolvimento Tecnológico - PADETEC está situado no campus da Universidade Federal do Ceará, em Fortaleza. Foi criado em maio de 1990, vinculado ao Centro de Treinamento e Desenvolvimento da Universidade Federal do Ceará - CETREDE, emancipando-se em 2000, quando foi instituído como entidade civil, sem fins lucrativos. Atualmente, o PADETEC é respaldado pelas seguintes instituições: Universidade Federal do Ceará - UFC, Banco do Nordeste - BNB, Secretaria da Ciência e Tecnologia do Estado do Ceará - SECITECE, Fundação Cearense de Amparo à Pesquisa - FUNCAP, Banco do Estado do Ceará - BEC, Federação das Indústrias do Estado do Ceará - FIEC, SEBRAE-CE, Secretaria de Desenvolvimento Econômico - SDE, Financiadora de Estudos e Projetos - FINEP, Conselho Nacional de Desenvolvimento Científico e Tecnológico - CNPq.

$\mathrm{Na}$ estrutura do PADETEC encontram-se um Centro de Pesquisas (composto por uma Central Analítica, Laboratórios, atua no desenvolvimento de novos processos e produtos e interage com a pós-graduação da Universidade), uma incubadora de base tecnológica e uma entidade associada, a empresa Analytica. A área física constitui-se de vinte e um galpões industriais, sendo quatorze de $50 \mathrm{~m}^{2}$, cinco com $68 \mathrm{~m}^{2}$ e dois com $200 \mathrm{~m}^{2}$, dispondo de instalações sanitárias, luz, água, esgoto e rede telefônica. O Centro de Pesquisas ocupa uma área de $560 \mathrm{~m}^{2}$, com laboratórios, central analítica, almoxarifado e setor administrativo, incluindo salas de trabalho.Conta também com uma Unidade de Produção de Medicamentos Genéricos, que faz parte do Programa Nacional de Produção de Medicamentos Genéricos, do CNPq, sendo a primeira unidade de produção desses medicamentos no Ceará. O modelo de funcionamento dessa unidade prevê o apoio às empresas incubadas ou emancipadas que tenham a intenção de atuar no mercado de medicamentos genéricos. 
Foram disponibilizados, durante o desenvolvimento da pesquisa, os principais indicadores referentes ao periodo de 1998 a 2000, a saber: 34 empresas incubadas, 12 emancipadas; o faturamento total no ano 2000 foi de $R \$$ 2,2 milhões; nos últimos cinco anos foram geradas 18 patentes e lançados 54 novos produtos no mercado; foram gerados 260 empregos indiretos, no período.

As áreas de atuação das empresas incubadas estão relacionadas principalmente ao desenvolvimento de novos produtos fitoterápicos, produtos alimentícios e para indústria moveleira, utilizando matéria prima da região, o que tem sido feito com grande sucesso. Além disso, também são encontradas empresas na área de eletro-eletrônicos. Muito da atuação dessas empresas decorre da tradição, da aproximação com professores da Universidade, principalmente nas áreas de química orgânica e inorgânica, química analítica $e$ físico-química, biologia, bioquímica, biologia molecular, farmácia e odontologia. A maior parte dos atuais componentes da equipe do PADETEC é constituída de professores aposentados da Universidade Federal do Ceará - UFC.

Ainda a respeito da equipe técnica do PADETEC, optou-se por um modelo de corpo técnico-científico próprio reduzido, negociando-se, ao nível de cada projeto ou empresa incubada, o pessoal necessário. Os projetos em andamento no âmbito do PADETEC, no ano 2000, contaram com oito bolsistas do CNPq, três bolsistas do RHAE/CNPq, dois bolsistas da FINEP (PADCT) e sete bolsistas do Projeto Bolsas IEL/SEBRAE/CNPq para o apoio ao desenvolvimento tecnológico das micro e pequenas empresas. Devido à forte interação com a Universidade, também existem alguns estudantes de pós-graduação dos cursos de química (mestrado e doutorado), bolsistas da CAPES, FUNCAP e CNPq, que desenvolvem nos laboratórios do PADETEC trabalhos de pesquisa, sempre vinculados aos projetos industriais (PADETEC, 2001).

$O$ relacionamento inter-institucional do PADETEC é outro ponto forte dessa experiência, não só com instituições de pesquisa, como também com empresas de grande porte. Entre esses relacionamentos destacam-se: o desenvolvimento de pesquisas nas áreas de química e produtos naturais com a Johnson\&Johnson Indústria e Comércio Ltda. (avaliação farmacológica de extratos vegetais de espécies selecionadas), cooperação técnica com a EMBRAPA Agroindústria Tropical (processamento de produtos de origem vegetal e animal), cooperação técnico-científica com a Rhodia Nutrição Animal Ltda. 
(aumento da produtividade de óleos essenciais em gramíneas, mediante utilização de citocininas), cooperação técnico-científica com a Fundação Oswaldo Cruz (desenvolvimento de medicamentos à base de extratos da espécie Spondias mombin para potencial aplicação no tratamento de Herpevirus e Papilomavirus). Faz-se interessante destacar que o PADETEC abriga atualmente, como empresa associada, a Analytica Análise Instrumental Ltda., que realiza análises instrumentais em produtos orgânicos e inorgânicos, tais como efluentes industriais, poluentes ambientais, pesticidas, resíduos de pesticidas em alimentos, bebidas, água, matrizes vegetais, entre outros, bem como desenvolve formulações à base de produtos naturais, com uma clientela que inclui empresas públicas e privadas.

O PADETEC tem apresentado diversos resultados positivos. Em 2000, a empresa ETETECH Desenvolvimento Tecnológico Ltda., incubada no PADETEC, foi uma das empresas vencedoras do Prêmio FINEP de Inovação Tecnológica, para a Região Nordeste, na categoria de Produto, por ter desenvolvido um novo Sistema de Irrigação Agrícola (SI Agrícola) automático, inédito no pais, que usa microcontroladores para o estudo do volume de água consumido nas plantaçồes, reduzindo o desperdício. Em 2002, A empresa NUTERAL-Nutrição Clínica, empresa nascida no PADETEC e hoje localizada no Km 6 da BR-116-Fortaleza, foi escolhida como a empresa do ano (prêmio outorgado pela ANPROTEC) por um júri constituído por representantes da ANPROTEC, CNPq, CNI/IEL e SEBRAE. Concorrem a este prêmio as mais de 1200 empresas, incubadas e emancipadas, oriundas de incubadoras brasileiras. O PADETEC também foi distinguido com o PREMIO ANPROTEC 2002 por ter incubado e abrigado a empresa vencedora.

\subsubsection{Porto Alegre Tecnópole}

O processo de institucionalização do projeto Porto Alegre Tecnópole constituiu-se em:

"num esforço multiinstitucional, realizado com o objetivo de aprimorar as condições locais de inserção competitiva no âmbito da produção de bens e serviços, tendo em vista o processo de globalização da economia. Trata-se de levar ao desenvolvimento pleno as potencialidades ora existentes no âmbito da ciência e da tecnologia tendo, por fim, a produção de bens e serviços resultantes de trabalhos intensivos em conhecimento."

(Porto Alegre Tecnópole, 1995). 
As articulações para este Projeto iniciaram-se por volta de 1993, com a vinda o professor Jean-Marie Martin, presidente do Pólo Europeu de Grenoble, que proferiu uma palestra em Porto Alegre sobre a experiência francesa, o que deflagrou um movimento encabeçado pela Prefeitura Municipal de Porto Alegre e a Universidade Federal do Rio Grande do Sul. Em 1994, a Prefeitura de Porto Alegre lançou o Plano de Desenvolvimento Econômico no qual um dos programas (Tecnologia e Trabalho) tinha como principal atividade a constituição do projeto Porto Alegre Tecnópole. No ano seguinte, foi organizada uma missão à França com o objetivo de conhecer, de perto, a experiência francesa em tecnópoles. A partir dessa visita, foi constituído um grupo de trabalho que preparou o Termo de Referência (Porto Alegre Tecnópole, 1995), que faz parte integrante do Termo de Cooperação do Projeto Porto Alegre Tecnópole, assinado pelos seguintes parceiros: Prefeitura Municipal de Porto Alegre, Universidade Federal do Rio Grande do Sul - UFRGS, Federação das Indústrias - FIERGS, SEBRAE-RS, Pontifícia Universidade Católica - PUC/RS e Universidade do Vale do Rio dos Sinos - UNISINOS. Aderiram ainda ao movimento o Governo do Estado do Rio Grande do Sul, a Federação das Associações Comerciais do Rio Grande do Sul e a Central Única dos Trabalhadores. A gerência do projeto está a cargo da Prefeitura Municipal de Porto Alegre.

Outro grande passo em direção ao estabelecimento do Projeto foi o acordo de cooperação com o governo francês, por intermédio do Ministério de Relações Exteriores do Brasil, cujas atividades iniciaram-se em 1996, envolvendo a vinda de consultores franceses.

A região metropolitana de Porto Alegre, atualmente com cerca de três milhões de habitantes, possui uma considerável infra-estrutura científicotecnológica, bem como conta com um centro de serviços especializados e com uma indústria diversificada. Existem na região metropolitana alguns projetos já em desenvolvimento que podem alavancar o projeto, estando divididos nas seguintes categorias: incubadoras e Regiões de Potencial Tecnológico (REPOTs).

No âmbito das incubadoras são as seguintes as iniciativas: Incubadora Empresarial Tecnológica de Porto Alegre - IETEC, Centro de Empreendimentos do Instituto de Informática - $\mathrm{CEI}$, Unidade de Desenvolvimento Tecnológico da UNISINOS - UNITEC, Incubadora Tecnológica da Fundação de Ciência e Tecnologia - ITC, Incubadora Empresarial da Restinga - IETINGA, Rede Gaúcha 
de Incubadoras - REGINC. No âmbito das Regiões de Potencial Tecnológico (REPOTs) são as seguintes as iniciativas: Parque Tecnológico Urbano do Quarto Distrito - Porto Alegre, Cidade Saúde - Porto Alegre, Parque Tecnológico da Região Metropolitana - Campus da Fundação de Ciência e Tecnologia do Rio Grande do Sul (Cachoerinha), Pólo de Informática de São Leopoldo.

De acordo com o projeto, a estrutura da Tecnópole será estabelecida em três esferas: a do Conselho de Gestores, a do Comitê de Coordenação e do Conselho Técnico Consultivo. $O$ Conselho de Gestores deve planejar as diretrizes e linhas de atuação da Tecnópole, acompanhar as ações tecnopolitanas em andamento e fomentar novas iniciativas. O Comitê de Coordenação tem caráter executivo, tendo como responsabilidades organizar as reuniões do Conselho de Gestores, selecionando os assuntos da pauta e divulgando-a nos meios de comunicação, bem como fazer as convocações dos gestores e comissões específicas. O Conselho Técnico Consultivo é integrado por personalidades reconhecidas por seu trabalho nos meios técnico ou científico, com formação e experiência voltadas a áreas do conhecimento de interesse para 0 desenvolvimento da Tecnópole. Estão operantes o Conselho de Gestores e o Comitê de Coordenação.

Conforme pôde ser abstraído durante a entrevista, o projeto direcionase para o que chamam de "Tecnópole Poli-Nucleada" (Porto Alegre Tecnópole, 1995), ou seja, um movimento buscando a interconexão entre os atores de inovação da região metropolitana.

Atualmente, a coordenação do projeto pela Prefeitura está focando os esforços no desenvolvimento do Parque Tecnológico do Quarto Distrito, muito bem localizado, junto ao aeroporto e às principais saídas de Porto Alegre.

\subsubsection{Londrina Tecnópolis}

Londrina Tecnópolis trata-se de uma experiência que se destaca, principalmente pelo potencial de articulação dos atores diretamente envolvidos no desenvolvimento deste projeto localizado no norte do Paraná.

O Estado do Paraná vem apresentando, nos últimos anos, uma agressiva política de investimentos com o intuito de desenvolver programas e projetos, visando alterar o perfil de desenvolvimento do estado, valorizando, nessa política, os pólos do interior. O Programa Paraná Tecnologia desenvolve 24 programas e projetos direcionados ao desenvolvimento tecnológico do Paraná. 
O projeto Londrina Tecnópolis encontra-se no contexto deste programa. O município de Londrina assinou um convênio em dezembro de 2000 , com vistas a alavancar o projeto que visa, sobretudo, articular a capacitação existente na região (universidades, centros de pesquisa, incubadoras de empresas, redes) para a formação do primeiro dos pólos tecnológicos regionais do Paraná.

Em 1998, foi sancionada pelo governador do Estado do Paraná a lei de criação da Região Metropolitana de Londrina (RML), formada pelos municípios de Londrina, Tamarana, Jataizinho, Ibiporã, Cambé e Rolândia, que compõem uma população de cerca de 630 mil habitantes, sendo a segunda maior região do Paraná em população e consumo de energia elétrica e água, ficando atrás somente da Região Metropolitana de Curitiba, criada por lei federal em 1973.

O Projeto Londrina Tecnópolis está fortemente ligado à atuação da Associação do Desenvolvimento Tecnológico de Londrina - ADETEC que, em seu nono aniversário, em 04 de outubro de 2002, por meio de uma sessão de Assembléia Geral Extraordinária, altera seu estatuto social para transformar-se em Organização da Sociedade Civil de Interesse Público - OSCIP. A ADETEC é reconhecida como de Utilidade Pública pelo Município de Londrina e pelo Estado do Paraná (1994), de caráter educacional e de fomento à pesquisa e ao desenvolvimento científico e tecnológico de Londrina e região, e pelo Governo Federal (2000). O objetivo superior do Projeto consiste na estruturação de um pólo de inovação tecnológica no eixo Cornélio Procópio - Apucarana. Segundo levantamentos feitos, nessa região existem diversos ofertantes de pesquisa e desenvolvimento, entre universidades e instituições de pesquisa, ativos de inovação tecnológica, entre incubadoras, programas de desenvolvimento tecnológico, condomínios industriais, companhia de desenvolvimento, e empresas tradicionais e de base tecnológica de vários setores industriais (Londrina Tecnópolis, 2001).

A ADETEC vem, desde 1993, atuando na tentativa de aproximar os ofertantes e demandantes de serviços tecnológicos, com o intuito de criar um ambiente fértil à promoção de inovações tecnológicas e consolidar a região como um pólo de inovação tecnológica. As ações da ADETEC culminaram na concepção, em 1998, do projeto Londrina Tecnópolis, cuja realização foi efetivamente desencadeada em janeiro de 2000. Dadas suas características o projeto enquadra-se na categoria de Pólo de Inovação Tecnológica. 
As articulações de parcerias para a viabilização de recursos para o projeto foram feitas durante no ano de 1999, envolvendo as seguintes entidades: Secretaria de Estado da Ciência, Tecnologia e Ensino Superior do Paraná - SETI, - Conselho Nacional de Desenvolvimento Científico e Tecnológico - CNPq, a Federação das Indústrias do Estado do Paraná/Instituto Euvaldo Lodi - FIEP/IEL, a Prefeitura Municipal de Londrina/CODEL/IPPUL, Universidade Estadual de Londrina - UEL, Instituto Agronômico do Paraná - IAPAR, Instituto de Pesquisas Tecnológicas de São Paulo - IPT.

O projeto foi estruturado a partir de uma análise das potencialidades e gargalos, realizada por setor, tendo como fronteiras os municípios situados no eixo Cornélio Procópio - Apucarana, esperando que estes municípios se engajem na meta de estruturação do pólo de inovação no horizonte de dez anos. No âmbito dessa análise, foram selecionados, para uma investigação detalhada, os três segmentos mais abrangentes e representativos da região: alimentos, químicos-fármacos e eletro-info-comunicação, este último abrangendo as áreas de eletro-eletrônica, informática e telecomunicações. A partir dessa análise foram então estruturadas seis ações estratégicas em apoio ao projeto: a Plataforma de Alimentos (PLATALI); a Plataforma Londrina de Tecnologia da Informação (PLATIN) que está integrada à REDE TIC PARANÁ, ao programa Paraná Classe Mundial e à SOFTEX; a Plataforma do Conhecimento - PLATCON, o Sistema de Informação e Apoio a Projetos (SIAP), o Programa de Articulação Empresarial e, finalmente, o Programa de Animação, para as ações de comunicação e marketing (Londrina Tecnópolis, 2001).

Atualmente o Projeto é gerido por um Comitê Executivo, instituído por resolução conjunta subscrita pelos parceiros do Projeto Londrina Tecnópolis, em 10 de novembro de 2000, tendo em sua composição representantes de: Companhia Paranaense de Energia Elétrica - COPEL, Associação Comercial e Industrial de Londrina - ACIL, Secretaria de Estado da Ciência, Tecnologia e Ensino Superior - SETI, Universidade Estadual de Londrina, CNPq, ADETEC, Instituto Agronômico do Paraná - IAPAR, SEBRAE/PR. Estão previstas as designações de representantes oficiais do Município de Londrina e do Ministério da Ciência e Tecnologia.

O Projeto também está sendo influenciado, sob o ponto de vista metodológico, pelas experiências européias de parques científicos-tecnológicos e 
tecnópoles. Esta influência decorre da realização de visitas técnicas às tecnópoles de Bilbao (Espanha), Bordeaux, Montpellier, Nantes, Rennes e Lille (França), todas elas implantadas na década de 1980. A partir dessa experiência e de outros contatos estabelecidos, foi instituído o Conselho Técnico Internacional do projeto, que se reúne uma vez por ano, durante a Jornada Tecnológica Internacional de Londrina. Atualmente, este Conselho está composto por: David Gibson (Austin, EUA), Daniel Leroy (Universidade de Lille, França), Ingrid Rosten (San Jose, EUA), Paolo Onesti (Democenter, Módena, Itália) e um componente brasileiro, Sylvio Goulart Rosa (Parque Tecnológico de São Carlos, São Paulo).

Destacam-se as ações de sensibilização ("animação") estabelecidas que estão sendo importantes para a divulgação e estabelecimento de cultura de empreendedorismo na região. Entre essas ações encontram-se: o jornal eletrônico "ADETEC News", emitido quinzenalmente, de forma regular, atingindo o meio empresarial, universidades, incubadoras, centros de pesquisa, entre outros; de setembro de 2000 a abril de 2001 , dispunham de um programa na televisão local (SBT), denominado "Londrina Tecnópolis", onde entrevistavam lideranças locais, personalidades e políticos em apoio ao Projeto.

\subsubsection{Porto Digital}

O Porto Digital é gerido pela Associação Núcleo de Gestão do Porto Digital que, por meio do Decreto Lei do Governo do Estado de Pernambuco $n^{\circ} 23.212$, de 20 de abril de 2001, foi qualificada como Organização Social.

“O objetivo é articular, estruturar e animar um ambiente de negócios de classe mundial em tecnologia da informação e comunicação no Bairro do Recife através da atração e localização de empresas, do fomento $e$ ao surgimento de novos empreendimentos, do apoio à inovação e aos negócios, e do marketing das instituições, empresas, produtos e serviços destes ambientes." (Núcleo de Gestão do Porto Digital, 2002).

Embutida nesse objetivo, encontra-se uma ação de recuperação de áreas urbanas degradadas e economicamente deprimidas, pela utilização do acervo arquitetônico e cultural presentes na região do Porto de Recife. O "Porto Digital" é um complexo de tecnologia e inovação estabelecido no coração do Recife antigo, em construções que estão sendo recuperadas, algumas delas datadas de 1654, época do domínio holandês na região.

A participação da academia neste processo se dá, principalmente, pela ação da Universidade Federal de Pernambuco - UFPE que tem, tradicionalmente, criado uma massa crítica de recursos humanos altamente qualificada na área de 
tecnologia da informação. Buscando dinamizar a relação universidade-empresa na área de tecnologia da informação, em 1995, foi criado o Projeto CESAR (Centro de Estudos Avançados do Recife), como uma empresa privada. O CESAR foi instalado no então Departamento de Informática da UFPE e começa a buscar projetos no mercado, sendo o primeiro cliente o grupo de supermercados Bom Preço. Nesse mesmo período, foram iniciados os projetos de criação de cinco empresas, projetadas por alunos do Departamento de Informática. Essas pequenas empresas, chamadas de unidades de negócio, passam por um período de amadurecimento dentro do CESAR, que atua como uma incubadora (muito embora não se utilize esse termo para designar essas atividades do Centro). Após esse periodo de amadurecimento, as jovens empresas se tornam independentes. O CESAR financia suas atividades (de pesquisa, de desenvolvimento e de produção) por meio dos serviços prestados aos clientes, que contratam consultoria, pesquisa aplicada, desenvolvimento de uma solução. A UFPE participa do processo cedendo o espaço e as instalações. É importante ressaltar a ligação estreita entre o CESAR e o Departamento de Informática da UFPE, segundo a entrevistada, não existindo barreiras culturais.

Em paralelo a tudo isso que acontecia no Departamento de Informática da UFPE, dentro do contexto do "Projeto Iniciativa por Pernambuco" ${ }^{1}$, são iniciadas discussões ao estímulo ao empreendedorismo. Como resultado, o programa de Ciências da Computação da UFPE insere uma disciplina relacionada a esse tópico no seu currículo, onde os alunos aprendem a desenvolver um plano de negócios. Ao final da disciplina, os vários grupos apresentam seus trabalhos e, dependendo do resultado, por meio de avaliação, recebem um maior ou menor incentivo para aprimorar os planos de negócios e lançarem suas empresas. Aqueles que avançam no processo passam por um período de pré-incubação (no próprio Departamento de Informática da UFPE) com apoio logístico para, posteriormente, se dirigirem para uma incubadora ou outras instituições ligadas às atividades de empreendedorismo (CESAR, Instituto Tecnológico do Estado de Pernambuco - ITEP). Nessa segunda fase, já como empresas, elas ainda

\footnotetext{
'Projeto Iniciativa Pernambuco - Um dos principais objetivos deste projeto é estimular a parceria público-privada como meio para solucionar os gargalos identificados em cada um dos seis principais clusters, ou aglomerados produtivos, em desenvolvimento em Pernambuco, a saber: turismo, fruticultura irrigada, informática, gesso, médicohospitalar e avicultura (vide http://www.condepe.pe.gov.br/iniciativa.htm).
} 
usufruem das instalações proporcionadas pela incubadora (ou similar) e preparam-se para o mercado. Muitas dessas jovens empresas encontram no CESAR um tipo de "agenciador" (ou broker), cuja ação está pautada na identificação e atração da demanda no mercado.

Apesar do acerto estratégico dessas iniciativas, esse conjunto de ações que constituem o chamado ecossistema formado no entorno da Universidade, não estava apresentando a visibilidade que o Governo do Estado desejava. Sendo assim, surge a idéia de se estabelecer o ITBC - Information Technology Business Center (Centro de Negócios de Tecnologia da Informação), que se constituiria em um local (único), um ponto comercial, que teria como objetivo abrigar as empresas incubadas na pré-incubadora, na Universidade, no CESAR, e facilitar as atividades do Programa SOFTEX Recife ${ }^{2}$, expondo as empresas a possiveis investidores.

Inicialmente, o ITBC deveria ser localizado no bairro do Recife Antigo. Entretanto, o projeto inicial foi expandido e, ao invés de contemplar apenas um imóvel, pensou-se em disseminá-lo por todo o bairro do Recife Antigo, ampliandose a proposta inicial para a construção de um ambiente de congregação de empresas. Surge assim a idéia de criação do Porto Digital, fazendo uso de uma infra-estrutura já razoavelmente instalada (todos os edifícios subutilizados e abandonados em uma área degradada e economicamente deprimida), evitando, com isso, alguns problemas, tais como as desapropriações de outras áreas.

O Porto Digital surge com o objetivo de aglutinar e organizar a economia digital do Estado em um ambiente cultural propício e alavancar o restante da revitalização do bairro. Os idealizadores do Porto Digital estão convictos de que o binômio tecnologia-cultura consegue gerar negócios de classe mundial, promovendo a desejada visibilidade internacional, para a região.

Os principais atores do projeto são: Governo do Estado de Pernambuco por meio de sua Secretaria Estadual de Ciência, Tecnologia e Meio Ambiente, a Universidade Federal de Pernambuco, por meio do seu Centro de Informática, o ITBC (em fase de implantação), o CESAR e o SOFTEX-Recife.

2 "O Softex Recife é uma associação que articula as principais empresas do setor de tecnologia da informação e comunicação de Pernambuco. No Porto Digital, o Softex Recife está localizado no ITBC, um edifício empresarial inteligente, com $5.000 \mathrm{~m}^{2}$ preparados para abrigar empresas da economia digital." (Núcleo de Gestão do Porto Digital, 2002). 
O financiamento é integrado pelo Governo do Estado, utilizando recursos provenientes da privatização de empresas, que devem ser utilizados em três linhas de ações principais: fundo de capital humano (fortalecimento da formação de recursos humanos), fundo de capital de risco (incluindo fundo de aval para suportar a instalação das empresas) e transferência de atividades já existentes em outras áreas da cidade para o Porto Digital (as chamadas âncoras, como o SOFTEX Recife, o CESAR, a Secretaria Estadual de Ciencia, Tecnologia e Meio Ambiente). O Escritório de Instalação do Porto Digital (também fazendo uso do aporte financeiro mencionado) tem como função atrair empresas para ali se instalarem. As empresas devem ser, prioritariamente, na área de tecnologias da informação e de comunicação para atender aos objetivos do Porto Digital. Entretanto, há a necessidade de empresas e serviços de suporte tais como consultoria, bares, restaurantes, agências de viagem, bancos.

Outra importante ação do Governo do Estado, fundamental para a atração das empresas, é a criação da rede de comunicação - Rede do Porto Digital $^{3}$ - interligando o bairro todo (serviços avançados, Internet rápida), cujos trabalhos já se iniciaram.

Em termos de espaço, o Porto Digital conta com um potencial de 200 mil $\mathrm{m}^{2}$. Dispõe de um cadastro de todos os imóveis disponíveis e realiza a intermediação de aluguel ou venda dos mesmos, face às necessidades de espaço específicas de cada empresa. Caso o imóvel escolhido esteja sujeito a obras de recuperação, os custos dessas obras devem ser arcados pelo proprietário do imóvel (e também pela empresa, através do fundo de aval).

Cabe ainda mencionar o lado social do projeto Porto Digital que se refere a re-urbanização e re-inserção social da comunidade do bairro, hoje definida como uma favela. Pretende-se, assim, a construção de habitações populares para essa comunidade, bem como gerar soluções para viabilizar que essa mesma população suporte os novos encargos da re-urbanização implementada. Essas atividades voltadas à inclusão social demandaram da

\footnotetext{
3 “Implantação da Rede do Porto Digital- esta estratégia tem como meta projetar, construir, implantar e operar uma rede de alta velocidade para interligar as instituiçōes âncoras do Porto Digital através da utilização dos dutos de fibra ótica e de outras infra-estruturas necessárias. $O$ projeto, que inicialmente prevê a interligação de 4 pontos institucionais, pode ser ampliado para atender aos condominios empresariais interessados em prover os serviços de valor agregado disponiveis na rede para seus condôminos, em particular para as empresas de tecnologia da informação e comunicação." (Núcleo de Gestão do Porto Digital, 2002).
} 
diretoria do Porto Digital ações para a criação de uma nova área em sua estrutura organizacional, de forma a permitir o aproveitamento das oportunidades de captação de recursos e o estabelecimento de novas parcerias. Foi então criado o "Instituto Porto Digital para Inclusão Social" que foi qualificado como uma Organização da Sociedade Civil de Interesse Público Federal (OSCIP), o que proporcionou a possibilidade de submeter propostas e receber financiamento de alguns projetos do Governo Federal. ${ }^{4}$

Os dois principais problemas enfrentados pelo projeto Porto Digital são: incentivos fiscais para a região (por exemplo, redução do ISS - Imposto Sobre Serviços, junto a esfera municipal) ainda se encontram na fase de projeto, dificultando a atração e a localização de empresas, principalmente aquelas da própria região; a inexistência de prédios prontos para receber as empresas, possibilitando o início de suas atividades de imediato (na maioria das vezes os imóveis necessitam de recuperação, encarecendo o projeto individual de cada empresa candidata). Além desses fatores, o Porto Digital localiza-se em uma área de patrimônio histórico (e artístico nacional) onde toda a intervenção é objeto de análises especiais pelos órgãos competentes. Apesar de muito jovem, o projeto Porto Digital já apresenta lições, entre elas, segundo informações obtidas durante a entrevista: foi subestimada a dimensão dos problemas em termos dos prazos de aprovação e execução dos projetos (por exemplo, das reformas dos edifícios, sujeita a legislação especial).

\subsubsection{Pólo de Alta Tecnologia de Campinas}

De acordo com Santos (2000) "a interiorização da indústria paulista e a modernização de sua agricultura expressaram-se no surgimento de áreas concentradas, tradicionalmente chamadas de pólos regionais, dentre os quais Campinas se destaca". Segundo a mesma autora, a influência de Campinas impacta o desenvolvimento econômico de cidades como Limeira, Piracicaba, Rio Claro, São Carlos, Araraquara, Jundiaí, Itu e Sorocaba.

$\mathrm{Na}$ região de Campinas encontram-se hoje concentradas indústrias de tecnologia de ponta, além de instituições de pesquisa e universidades que são

\footnotetext{
4 "Uma das motivações para a criação do Instituto é que o Núcleo de Gestão do Porto Digital, por ser qualificado como Organização Social, não pode ser qualificada como OSCIP na legislação vigente. Portanto, o Núcleo de Gestão não poderia submeter projetos a certos editais, inviabilizando a realização das ações necessárias na área de inclusão social."(Núcleo de Gestão do Porto Digital, 2002).
} 
referência nacional na produção científica e tecnológica. Identificando esta situação como oportunidade estratégica, a Prefeitura Municipal de Campinas criou, por meio de decreto de dezembro de 1985 e posteriormente transformada em empresa municipal - Decreto Lei ${ }^{\circ} 6.850$ de 17 de dezembro de 1991, a Companhia de Desenvolvimento do Pólo de Alta Tecnologia de Campinas CIATEC. É uma empresa de economia mista, tendo $99 \%$ de suas ações pertencentes à Prefeitura de Campinas. A Prefeitura aporta recursos através do estabelecimento de contratos de prestação de serviços com a CIATEC (para o ano 2001 , recursos da ordem de $\mathrm{R} \$ 500 \mathrm{mil} / \mathrm{ano}$ ) para que possa desenvolver suas atividades, a saber:

- Planejar e executar a política de ciência e tecnologia de Campinas;

- Coordenar a implantação de empresas e organizações de pesquisa científica e tecnológica no Pólo de Alta Tecnologia, em duas áreas da região constituindo o Parque I e o Parque II;

- Consolidar a região de Campinas como Pólo Tecnológico;

- Operar o Núcleo de Apoio ao Desenvolvimento de Empresas - NADE, uma incubadora de empresas de base tecnológica.

Qualquer empresa que queira se instalar nas áreas sob administração da CIATEC tem que ter a anuência da mesma e ser compatível com o desenvolvimento da região em termos de tecnologia e de alta tecnologia.

Os Parques ficam próximos à Universidade Estadual de Campinas UNICAMP. Os terrenos são, em parte, públicos e em parte privados (entre eles áreas rurais e fazendas). A CIATEC estimula os proprietários privados a desenvolverem, com investidores, projetos de condomínios industriais (áreas menores, de três a cinco mil $\mathrm{m}^{2}$ ). A provisão de benefícios (arruamento com sarjetas, galerias pluviais) acontece, por vezes, por ação da Prefeitura e não da CIATEC, cuja função é acomodar a ocupação das áreas, estimulando e incentivando a alocação industrial de cunho altamente tecnológico, resguardando o meio ambiente.

O Parque I localiza-se na Rodovia Dom Pedro I, km 104, perto da Rodovia Anhanguera e abriga empresas vinculadas ao segmento tecnológico, porém não de alta tecnologia. São 49 lotes de terreno com áreas cujas dimensões variam entre 4.000 e $23.000 \mathrm{~m}^{2}$, sendo que nove empresas já adquiriram lotes. 
O Parque II tem seus limites físicos junto ao Campus da UNICAMP e da Pontifícia Universidade Católica - PUCCAMP, ocupando uma área de 7.000.000 $\mathrm{m}^{2}$ (rodovia Campinas-Mogi Mirim, SP340). As empresas ou instituições já instaladas são de tecnologia de ponta como, por exemplo, a XTAL Fibras Óticas S/A, a Magneti Marelli Divisão Eletrônica, o Laboratório de Luz Síncrotron (LNLS), entre outras ${ }^{5}$.

A Incubadora de Empresas NADE foi fundada em 1995. Todas as empresas incubadas são "spin-off" da Universidade e dos Centros de Pesquisa da região, ou seja, do sistema de pesquisa e desenvolvimento da região de Campinas. A incubadora encontra-se num momento de término de um ciclo onde algumas empresas já se graduaram, em 2000, e outras (doze empresas) estão em processo de graduação - e início de um outro, com novas candidatas buscando espaço. O processo de apresentação de projetos e seleção dos mesmos é feito por meio de edital e de concorrência pública. O período de incubação é de dois anos, renovável por mais dois. Entretanto, há uma proposta de alteração do tempo de permanência das empresas para três anos, renovável por mais um ano. As empresas pagam uma taxa de ocupação, que inclui alguns serviços (tais como eletricidade e telefonia). Ainda é prematuro proceder a uma análise sobre a performance das empresas incubadas e recentemente graduadas frente ao mercado. O mercado principal dessas empresas ainda é o nacional, muito embora algumas delas já estejam buscando inserção internacional.

Um fator que muito contribuiu para que a região de Campinas se tornasse um pólo tecnológico está relacionado à política de redução de impostos. Entre os benefícios fiscais oferecidos para as empresas que se instalam no pólo encontram-se: a isenção de Imposto Predial e Territorial Urbano (IPTU) e de Imposto Sobre Serviços de Qualquer Natureza (ISSQN), durante um prazo de cinco a dez anos, entre outros incentivos que variam de acordo com os projetos.

Os atores principais de todo esse processo são: o empresário (ator central); a Prefeitura de Campinas; a comunidade local, que responde com uma atitude pró-ativa com relação ao projeto. Em termos financeiros, o ator principal do projeto global é a Prefeitura de Campinas e, em termos da Incubadora de

\footnotetext{
"Informações obtidas em http://www.ciatec.ora.br .
} 
empresas, o SEBRAE se constitui em um parceiro muito importante, pois apóia as empresas incubadas diretamente.

\subsubsection{Parque Tecnológico do Rio de Janeiro}

O Parque Tecnológico do Rio de Janeiro é localizado no campus da Universidade Federal do Rio de Janeiro - UFRJ, na liha do Fundão, Rio de Janeiro. O Parque, sem personalidade jurídica própria, é um projeto da UFRJ, tendo a autorização para a sua implementação sido concedida pelo Conselho Universitário, em 8 de maio de 1997. As obras de infra-estrutura tiveram início em novembro de 1999 e ainda se encontram em execução. O lançamento comercial do Parque foi realizado em 2002. É importante ressaltar que a Incubadora de Empresas da Coordenação de Programas de Pós-Graduação em Engenharia COPPE/UFRJ - parte integrante do projeto Parque Tecnológico do Rio de Janeiro - já se encontra em operação desde 1995, tendo, inclusive, graduado algumas empresas. Pela sua localização, natureza de suas atividades e envolvimento da universidade hospedeira (UFRJ) no projeto, o Parque Tecnológico do Rio de Janeiro se ajusta perfeitamente à concepção de um Parque de Ciência e Tecnologia.

O Parque Tecnológico do Rio de Janeiro mescla sua história com a da UFRJ, da COPPE e de sua incubadora de empresas. O Parque faz parte o Plano Estratégico para a Cidade do Rio de Janeiro, em sua estratégia "Rio Competitivo", que busca recuperar a competitividade da cidade no contexto da economia globalizada $^{6}$. A COPPE, desde 1970, acumula uma experiência muito grande atuando na interface do relacionamento com a indústria. Criou um escritório de transferência de tecnologia, a COPPETEC, que administra hoje uma carteira de mais de mil projetos por ano, apresentando um faturamento, para o ano 2000 , de aproximadamente $\mathrm{R} \$ 50$ milhões. A instituição tem uma forte tradição em termos de cursos de pós-graduação em engenharia e pretende também oferecer cursos de graduação nas áreas de meio ambiente, petróleo e informática.

Em 1986, a COPPE estava terminando as negociações de um projeto com a Organização dos Estados Americanos - OEA e a Financiadora de Estudos e

\footnotetext{
${ }^{6}$ Plano Estratégico do Rio de Janeiro tem entre seus projetos: o Parque Tecnológico, a FavelaBairro, o Porto de Sepetiba, o Programa de Design do Rio de Janeiro, Revitalização do Centro, Teleporto. (disponivel em: http://www.rio.ri.gov.br/planoestrategico/pl proje1.html, acesso em 21/01/2003).
} 
Projetos - FINEP para avaliar, na América Latina, o estado-da-arte de incubadoras, parques tecnológicos e outros mecanismos assemelhados. Esse projeto de pesquisa foi concluído com a realização de um seminário internacional sobre parques tecnológicos, em dezembro de 1987. Este evento pode ser considerado o primeiro na América Latina, e possivelmente o primeiro no Hemisfério Sul, sobre parques tecnológicos. Como conseqüência desse projeto e seminário, foi criada uma associação: a ANPROTEC - Associação Nacional das Entidades Promotoras de Empreendimentos de Tecnologias Avançadas. Em 1990, foi então idealizada a criação de uma incubadora na COPPE, considerando-se ambas as experiências: a de relacionamento com as empresas e a obtida com a realização do projeto financiado pela OEA e FINEP.

Em termos físicos, a alocação de espaço dentro do campus é competência do Conselho Universitário. No decorrer desse processo, obteve-se a autorização da Reitoria da UFRJ para a utilização de um "barracão" - um pequeno prédio de mais ou menos $200 \mathrm{~m}^{2}$ - que estava subtilizado já havia algum tempo. As primeiras empresas foram selecionadas e começaram a funcionar em condições extremamente precárias de instalação - mas foi também um período muito rico e de aprendizado - uma relação de construção de um projeto em conjunto. Em paralelo, foi feito um projeto de construção da incubadora e apresentado à Prefeitura da cidade do Rio de Janeiro que, após algumas dificuldades de ordem jurídica que foram superadas, aprovou o projeto. A obra foi concluída em 1995. Foi nesse momento que, apesar de alguns focos de resistência na comunidade acadêmica, o Conselho Universitário aprovou o projeto da incubadora por unanimidade. $O$ prédio, por opção dos idealizadores, é pequeno, abrigando um total de doze empresas.

Em termos de critérios de seleção de empresas, este segue uma rotina comum à maior parte das incubadoras, iniciando-se com a apresentação de um plano de negócios pela empresa candidata. O Conselho que delibera sobre a aceitação ou não da candidata tem representantes da Universidade, da Prefeitura da Cidade do Rio de Janeiro, do Governo do Estado, do SEBRAE, da Federação das Indústrias do Estado do Rio de Janeiro - FIRJAN, da FINEP, do BNDES (este último, com uma participação em caráter mais informal).

Em termos de financiamento, a incubadora contou com um pacote de investimentos: Prefeitura do Rio de Janeiro (construção do prédio); Universidade 
(terreno); FINEP (aquisição de equipamentos, mobiliário - financiamento a título de empréstimo); Fundação de Amparo à Pesquisa do Rio de Janeiro - FAPERJ; SEBRAE-RIO (despesas de custeio) e, mais recentemente, o SEBRAE Nacional, que passou a apoiar as incubadoras em nível nacional. Em termos operacionais, as empresas cobrem cerca de $40 \%$ do custo; a Universidade, além de proprietária do terreno, paga o salário de duas pessoas e a segurança, e tem alguma gerência em termos administrativos. Para o restante das despesas, são captados recursos no mercado, por meio de projetos e parcerias.

A implantação do Parque Tecnológico é uma conseqüência e mesmo uma necessidade para ampliar as atividades da própria incubadora. Muitas das empresas que se graduam na incubadora não são grandes o suficiente para construir uma sede própria e até mesmo, pela própria natureza de suas atividades, necessitam de um lugar apropriado para operar, o que não e muito fácil de encontrar no Rio de Janeiro. Assim, existe a idéia de se construir um edifício, dentro do Parque, que abrigue algumas empresas desse tipo e que terão alguns serviços compartilhados. O terreno disponivel para a construção do Parque deve abrigar cerca de 200 empresas, de várias dimensões, e a idéia central é alugar o terreno (com infra-estrutura) e as empresas serem responsáveis pela construção de suas dependências. Os atores principais desse processo são a UFRJ, a Prefeitura do Rio de Janeiro (recursos financeiros, humanos e espaço) e o Governo do Estado (apoio político).

\subsubsection{Kyriat Weizmann Science Park}

O modelo de parques tecnológicos e incubadoras em Israel tem por objetivo apoiar as políticas públicas na promoção do desenvolvimento da indústria de alta tecnológica (high tech) no país, bem como gerar novos postos de trabalho e oportunidades para a mão-de-obra altamente qualificada disponível na região. Essa orientação política está baseada na Lei da Pesquisa e Desenvolvimento e nas ações governamentais que suportam essas atividades com vistas à geração de produtos de exportação com alto valor agregado. Essas políticas são decorrentes da necessidade de implementar novas opções para o desenvolvimento econômico de Israel, um país pequeno, em região árida e hostil, com carência de recursos naturais, com dificuldade de acesso a mercados, mercado interno pequeno e marcado pelo baixo valor agregado nas atividades da economia clássica. 
As ações relacionadas à promoção de incubadoras e parques científicos e tecnológicos estão sob a coordenação do Ministério da Indústria e do Comércio, por meio do seu Departamento do Cientista Chefe (DCC). Esses órgãos tem reconhecida e destacada atuação em apoio ao movimento de incubação de empresas. A partir dessa atuação podem ser observados os seguintes benefícios para as incubadoras e incubados: alto índice de incentivo para empreendedores tecnológicos, criação de novas empresas, sucesso no desenvolvimento de novos produtos tecnológicos, alto índice de captação de tecnologias estrangeiras, efetiva transferência de tecnologia das universidades para empresas, incremento na criação de postos de trabalho, absorção de imigrantes com alto nível acadêmico, principalmente provenientes da antiga União Soviética, atração de investimentos para as regiões. ${ }^{7}$

A Rede de Incubadoras de Israel tem por missão promover o desenvolvimento de idéias tecnológicas inovadoras em "fase zero", provenientes de empreendedores individuais, e criar novas empresas para sua comercialização.A rede é composta por 24 incubadoras que são articuladas por uma autoridade central. São os seguintes os principais resultados obtidos (dados de 2001):

- Dos 935 projetos aceitos para incubação, 735 foram graduados, sendo que 374 continuaram nos negócios;

- US\$590 milhões foram investidos (investimentos privados) em empresas graduadas de incubadoras;

- Várias empresas encontram-se na Bolsa de Valores (Estados Unidos e Europa). ${ }^{8}$

Em Israel existem quatro modelos de parques científicos e tecnológicos, a saber:

Modelo 1: O parque é construído e gerenciado por uma empresa à qual pertencem os edifícios e demais instalações. A empresa é responsável pelo

\footnotetext{
${ }^{7}$ As informações foram obtidas a partir das entrevistas realizadas com o Prof. Dr. Samuel Jerozolimski, em agosto de 2002, em apoio à aplicação do questionário. Informações disponiveis no Relatório de Auxílio Visitante, Processo FAPESP 02/02931-7, de agosto de 2002.

${ }^{8}$ Dados obtidos na apresentação feita pelo Prof. Dr. Samuel Jerozolimski em Mesa Redonda organizada pelo Núcleo de Política e Gestão Tecnológica da Universidade de São Paulo NPGT/USP, em 21 de agosto de 2002, na Sala de Congregação da Faculdade de Economia e Administração da USP. Apresentação incluída no relatório acima citado.
} 
fornecimento dos serviços de apoio aos empresários que ali se instalam. Entre exemplos desta modalidade estão os Kiryat Weizmann e o Matam Science Park,

Modelo 2: $O$ parque consiste numa concentração de empresas numa determinada área geográfica. Os edifícios e instalações pertencem às empresas tecnológicas ali instaladas ou são arrendados pela empresa construtora do empreendimento, integralmente ou de forma parcelada. Entre exemplos desta modalidade estão: Tamar/Rabin e Atidim Science Parks;

Modelo 3: $O$ parque consiste na organização de mecanismos de comercialização junto a entidades de pesquisa científica e tecnológica. Este modelo apresentou um sucesso limitado.

Modelo 4: Nesta modalidade, as empresas instaladas pertencem aos proprietários do parque (parque "Aldeia das Rosas").

O Kyriat Weizmann Science Park foi inaugurado em 1972 e, desde então, tem desenvolvido um processo contínuo de expansão, ocupando uma área de aproximadamente 40 acres, com cerca de $115.000 \mathrm{~m}^{2}$ de área construída.O Parque foi criado a partir da atuação do Weizmann Institute of Science, fundado em 1934 por aquele que foi o primeiro Presidente do Estado de Israel, Dr. Chaim Weizmann. O Instituto conta com um contingente de aproximadamente 2.500 trabalhadores e colaboradores que desenvolvem atividades científicas e tecnológicas nas áreas de ciências da vida, física, química, matemática e ciências da computação. Dezenas de empresas líder mundiais, de alta tecnologia, estão instaladas no Parque, entre elas: INDIGO, InterPharm, General Biotechnology, NOVA, DPharm, PEPTOR, Harlan Biotech, QBI, XTL, Pharmos.

O Parque foi construido e é operado pela África Israel Investments Ltd. Possui uma incubadora de empresas tecnológicas, a ITEK - Incubator for Technological Entrepreneurship Kiryat Weizmann Ltd., fundada em 1991, tendo como fundadores a Yeda Research andDevelopment Co. Ltd. E a África Israel Investments Ltd. A ITEK oferece serviços de logistica (disponibiliza espaço, secretaria, comunicações, serviços gerais, de contabilidade e advocacia); realiza a interface com o Departamento Cientista Chefe do Ministério de Indústria e Comércio; realiza acompanhamento financeiro, técnico e comercial dos incubados; disponibiliza apoio para os aspectos de gerência dos negócios, patentes, marketing, treinamento. A incubadora recebe projetos nas áreas de: ótica e eletro-ótica, tecnologia industrial, eletro-mecânica, materiais, biotecnologia, 
agrinegócios, tecnologia médica. Identifica-se como fatores de sucesso da incubadora os seguintes aspectos e práticas: critérios rígidos de admissão e um completo processo de seleção; apoio financeiro, principalmente proveniente do Departamento Cientista Chefe; condições ambientais propícias, tanto sob o aspecto de instalações quanto de proximidade com laboratórios e suporte técnico do Instituto Weizmann; ampla rede de contatos internacionais; acompanhamento, controle e gestão dos projetos pelo gerente da incubadora; credibilidade moral.

\subsubsection{Parque Tecnológico de Andalucía S.A.}

O Parque Tecnológico de Andalucía S.A.- PTA tem como objetivo se configurar como um núcleo de inovação tecnológica com efeitos diretos na indústria da região de Andalucía, tornando-se uma entidade promotora de sinergia entre os agentes locais de inovação. Os antecedentes históricos apontam para uma ação da "Junta de Andaluciá, por meio da "Empresa Publica Del Suelo de Andalucia" e do "Instituto de Fomento de Andalucia", que resultou em um convênio firmado, em 1988, com o "Ayuntamento de Málaga", cujo objeto era a criação de um núcleo dinamizador de inovação tecnológica. Este convênio deu origem ao Parque Tecnológico de Andalucía, situado em Málaga, cuja construção iniciou-se em 1989 e foi inaugurado pelos reis da Espanha, em dezembro de 1992.

A associação IDEA - Investigación y Desarrollo en Andalucia, que conta entre seus associados com empresas, associações de classe e o próprio PTA, foi criada nessa mesma época (1991) com o objetivo de cuidar da implantação, fomento e desenvolvimento do Parque, de forma a assegurar o seu sucesso. Entre suas atribuições encontram-se: colaborar com instituições locais para apoiar a captação de projetos para o PTA, com o objetivo de promover uma ocupação ordenada do Parque; colaborar com a gestão do PTA para otimizar os serviços gerais; apoiar os associados na obtenção de financiamento e subsidios para seus projetos, bem como assessorá-los na correta utilização de incentivos e benefícios fiscais; assessorar seus membros no que concerne ao uso do solo onde os associados implantarão seus projetos; promover a criação e fomentar empresas de serviços auxiliares para as atividades a serem desenvolvidas pelos associados; promover a transferência de tecnologia no âmbito do PTA.

Instalado na região do "Valle Del Guadalhorce", em uma área de 168 hectares, no limite ocidental do município de Málaga, próximo a um bairro 
denominado Campanillas (criado a partir da instalação do PTA), o Parque está a $13 \mathrm{~km}$ do Centro de Málaga, a $7 \mathrm{~km}$ do campus da Universidade de Málaga e a 6 $k m$ do Aeroporto Internacional de Málaga, sendo servido pela nova estrada do "Valle Del Guadalhorce". As normas ambientais aplicadas ao PTA são reguladas pelo "Ayuntamento de Málaga", por meio dos órgãos municipais de meio ambiente. São considerados nessas normas parâmetros de emissões gasosas, de emissões acústicas, de radiações ionizantes, de águas residuais e de resíduos industriais.

Confirmando o ambiente propício para o desenvolvimento de um Parque Tecnológico, a região de Málaga conta com um dos maiores crescimentos de população universitária da Espanha, com um número de alunos superior a 40.000, incluindo pós-graduação. Além disso, a Universidade de Málaga desenvolve estreita colaboração com o PTA por meio de seus grupos de pesquisa e centros, havendo mais de cem alunos e recém titulados trabalhando como estagiários nas empresas do Parque. Entre os centros e grupos de pesquisa que desenvolvem parceria com o PTA encontram-se: Centro de Tecnologia da Imagem, Grupo de Engenharia Mecânica, Grupo de Estudos Energéticos, Grupo de Engenharia de Software, Grupo de Engenharia de Sistemas Integrados, Grupo de Pesquisas Aplicadas em Matemática e Computação, Grupo de Inteligência Computacional e Análise de Imagens, Grupo de Arquitetura e Desenho, Grupo de Microeletrônica Informática, Grupo de Pesquisas e Aplicações em Inteligência Artificial, Andalucia Digital Multimídia, Instituto de Processo de Imagem, entre outros (IDEA, 2002).

Em 10 anos de existência, o PTA passou de oito empresas instaladas no início de sua operação para 250 empresas instaladas em sua área, atualmente. A maior parte delas dedicadas à tecnologia da informação e às comunicações (correspondendo a $75 \%$ do faturamento das empresas do Parque, faturamento este que se encontra por volta de 500 milhões de Euros anuais).O Parque gera 4.000 empregos diretos.

Com forte atuação no âmbito internacional, o Parque abriga a sede da International Association of Technology Parks - IASP, desempenhando um papel coordenador de suas atividades. Também encontra-se instalada no PTA a sede da Asociación de Parques Tecnológcios y Científicos de Espana - APTE, que é uma peça chave no sistema de ciência e tecnologia e relações com empresas no 
cenário espanhol. Estão instaladas no Parque mais de 50 empresas estrangeiras. O PTA participa de diversas redes e projetos internacionais, entre eles: Atlantic Technology Parks - ATLANTIS (T2A), rede Andalucía-Montpellier-Bari - AMBAR, rede Málaga-Sevilla-O Porto-Sheffield-La Vienne - COPAINS.

\subsubsection{TAGUSPARQUE S.A.}

O Tagusparque (TagusPark) é um Parque de Ciência e Tecnologia, em pleno funcionamento, localizado no Conselho de Oeiras, na área da Grande Lisboa, tendo sido originado a partir de ações da iniciativa privada, com o apoio de entidades públicas. 0 Parque ocupa uma área de cerca de 200 dos 360 hectares que faz parte de um Plano Integrado de atividades de ciência, tecnologia, lazer e serviços. Este Plano Integrado está intimamente ligado a um objetivo de revitalização de áreas, sendo que o Parque encontra-se localizado na confluência dos Conselhos de Oeiras, Cascais e Sintra, região esta reconhecida como uma área turística de grande importância em Portugal. Como indicadores gerais de impacto do Parque destacam-se: 5.060 postos de trabalho, 146 entidades instaladas, volume de negócios agregado - 917,8 milhões de Euros (TAGUSPARK, 2001). Interessante destacar entre esses indicadores que a população do Parque é jovem sendo que $57 \%$ do pessoal encontra-se na faixa dos 20 a 30 anos; $81 \%$ têm menos de 40 anos.

A estrutura do Parque é composta por: um Núcleo Central, localizado num edifício multifuncional, onde está instalada a entidade gestora (a Tagusparque S.A.) e uma área de serviços de conveniência; o Centro de Congressos do Núcleo Central, que dispõe de um auditório para 300 lugares, de uma Área de Exposições (aproximadamente $2.000 \mathrm{~m}^{2}$ ) e um conjunto de dez salas de reuniões com capacidade para até 70 lugares; no aspecto lazer, existe um Health Club completo; a Área para as Micro e Pequenas Empresas de Base Tecnológica, dispondo de um conjunto de oito edifícios (escritórios, laboratórios e áreas de produção); o Centro de Inovação Empresarial, que integra uma incubadora de idéias, uma incubadora de empresas de base tecnológica em início de atividades e uma área para pequenas e médias empresas, estando atualmente instaladas no Centro mais de 100 empresas (1.700 postos de trabalho, volume de negócios agregado - 250,6 milhões de Euros) com os seguintes perfis - tecnologia da informação (44\%), eletrônica $(19 \%)$ e telecomunicações (18\%) entre outras áreas de atuação. 
Os parceiros do Parque são:

- $\mathrm{Na}$ área de Ciência\&Tecnologia: Instituto de Soldadura e Qualidade, Instituto Superior Técnico, Universidade Técnica de Lisboa, Instituto de Engenharia de Sistemas e Computadores, Universidade Atlântica, Instituto de Biologia Experimental e Tecnológica;

- Na área empresarial: Banco Comercial Português (BCP), Portugal TELECOM.

O Tagusparque também atraiu para suas instalações subsidiárias portuguesas de algumas empresas multinacionais de alta tecnologia, a saber: Convex, Intergraph, Silicon Graphics, Schlumberger, Anixter, Rockwell e Origin. Além disso, o Tagusparque é sede da Associação Portuguesa de Parques de Ciência e Tecnologia - TECPARQUES.

As atividades de animação do Parque são bem organizadas e têm por objetivo criar um movimento cientifico-tecnológico, cultural e social que beneficie todos os seus integrantes. São desenvolvidas, desta forma, ações tais como: eventos culturais, ações e eventos de divulgação científica e tecnológica, estímulo à criação de redes informais no Parque, ações de intercâmbio científico e de cooperação internacional que, no conjunto, auxiliam e ampliam a boa imagem que o Parque possui.

\subsection{Discussão e interpretação dos resultados}

Conforme mencionado no capítulo 5 , foi elaborada uma matriz lógica resumida acrescida da seleção das práticas de sucesso identificadas. Na TAB. 6.1 apresenta-se a matriz de consolidação dos aspectos relevantes dos planos estratégicos identificados nas experiências analisadas. Esta prática contribui para a formulação dos aspectos estratégicos e de políticas públicas do modelo ora em desenvolvimento.

$\mathrm{Na}$ TAB. 6.2 são mostrados os aspectos ou práticas relevantes das experiências analisadas na pesquisa de campo, que subsidiam o desenvolvimento do modelo a ser proposto no capítulo 7, relacionando-se com as dimensões analisadas na pesquisa de campo (conclusão referente à pesquisa de campo). Na coluna de "resultado da apuração da pesquisa de campo" são levados em conta, nas opções com dados quantitativos, os aspectos que confirmaram a prática por número maior ou igual a $50 \%$ entre os entrevistados, 
tendo sido descartados aqueles que não se manifestaram ou que não praticam os aspectos considerados. Na segunda coluna da TAB. 6.2 são apresentados a interpretação e os comentários, considerando também informações obtidas dos estudos exploratórios. 


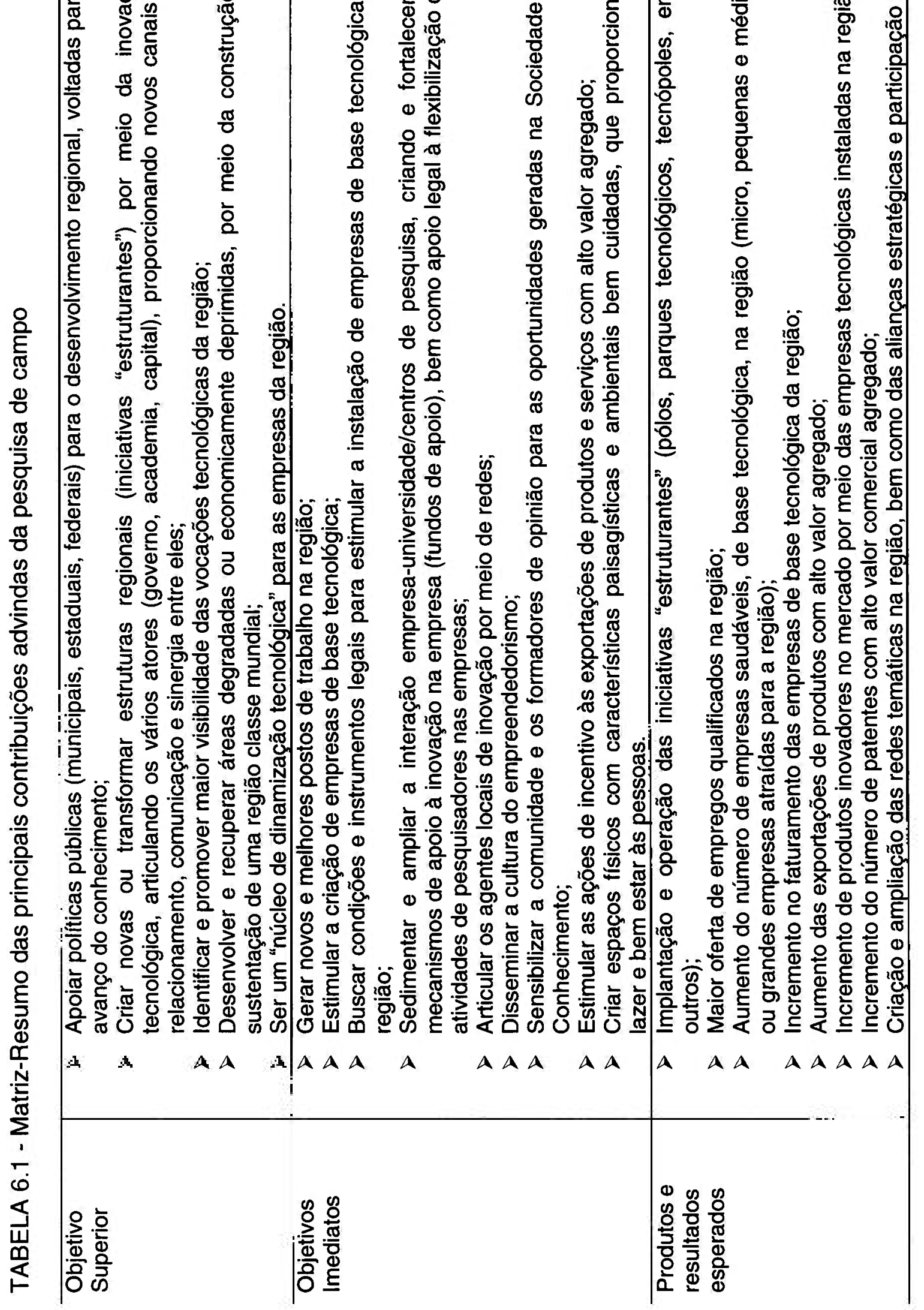




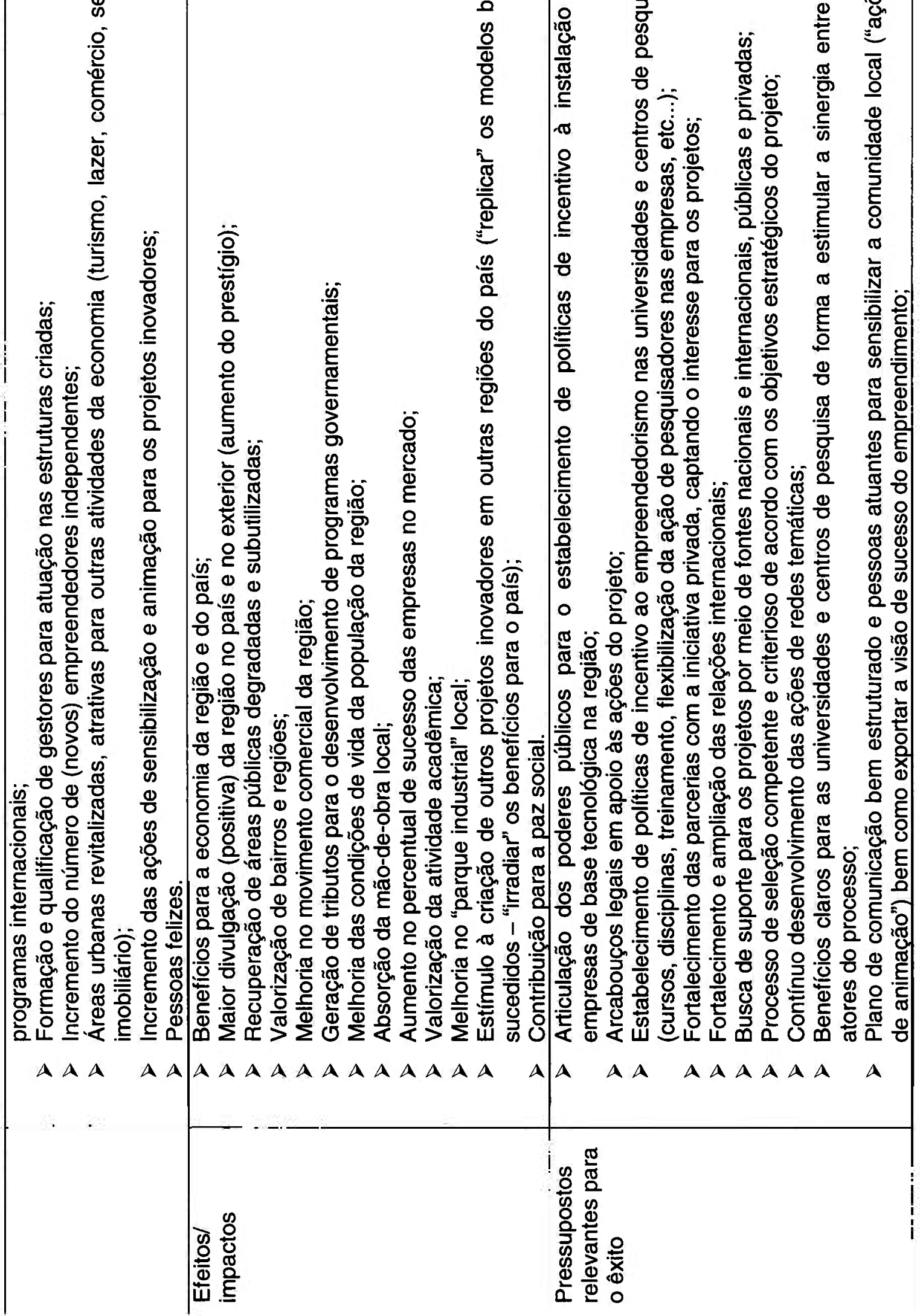




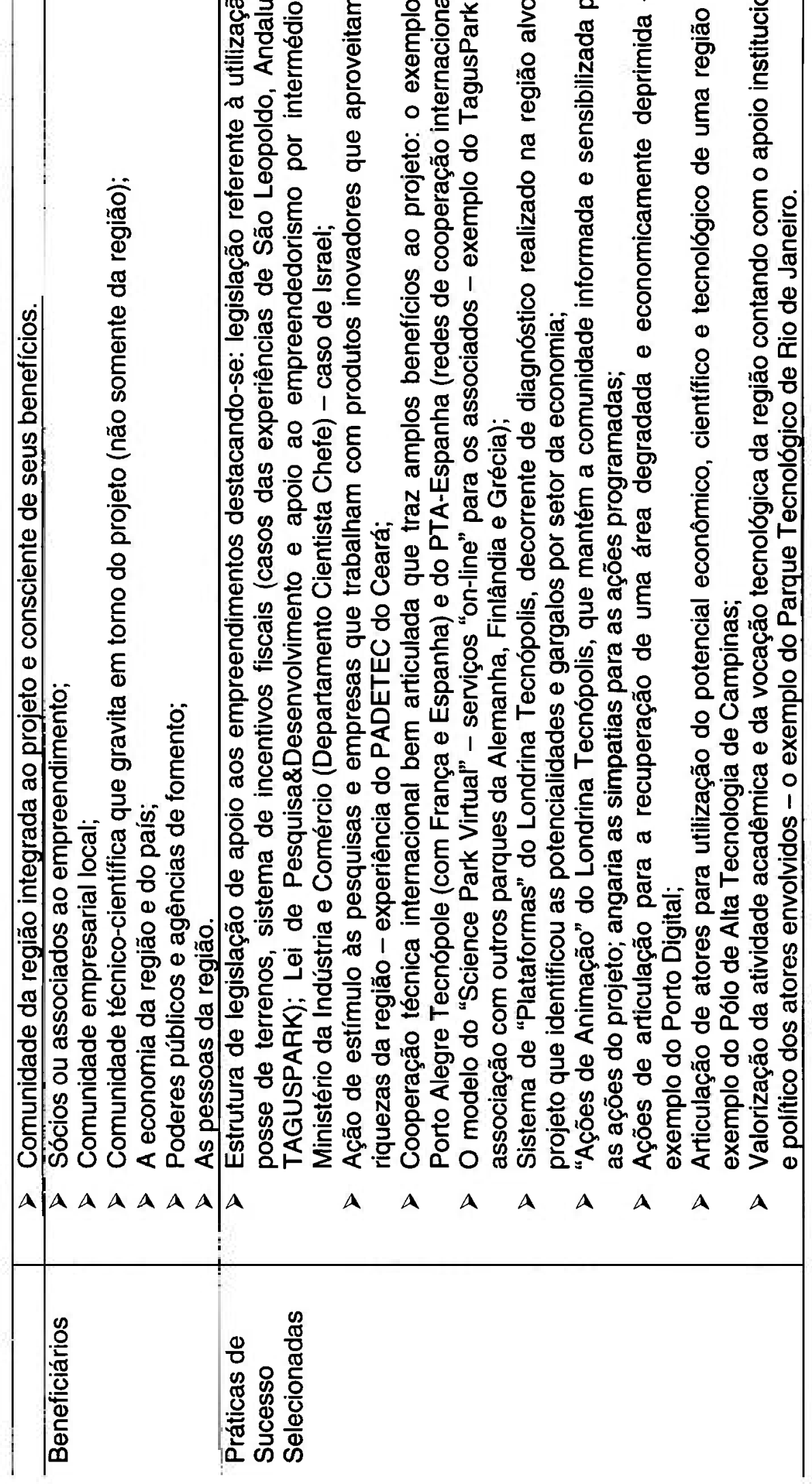




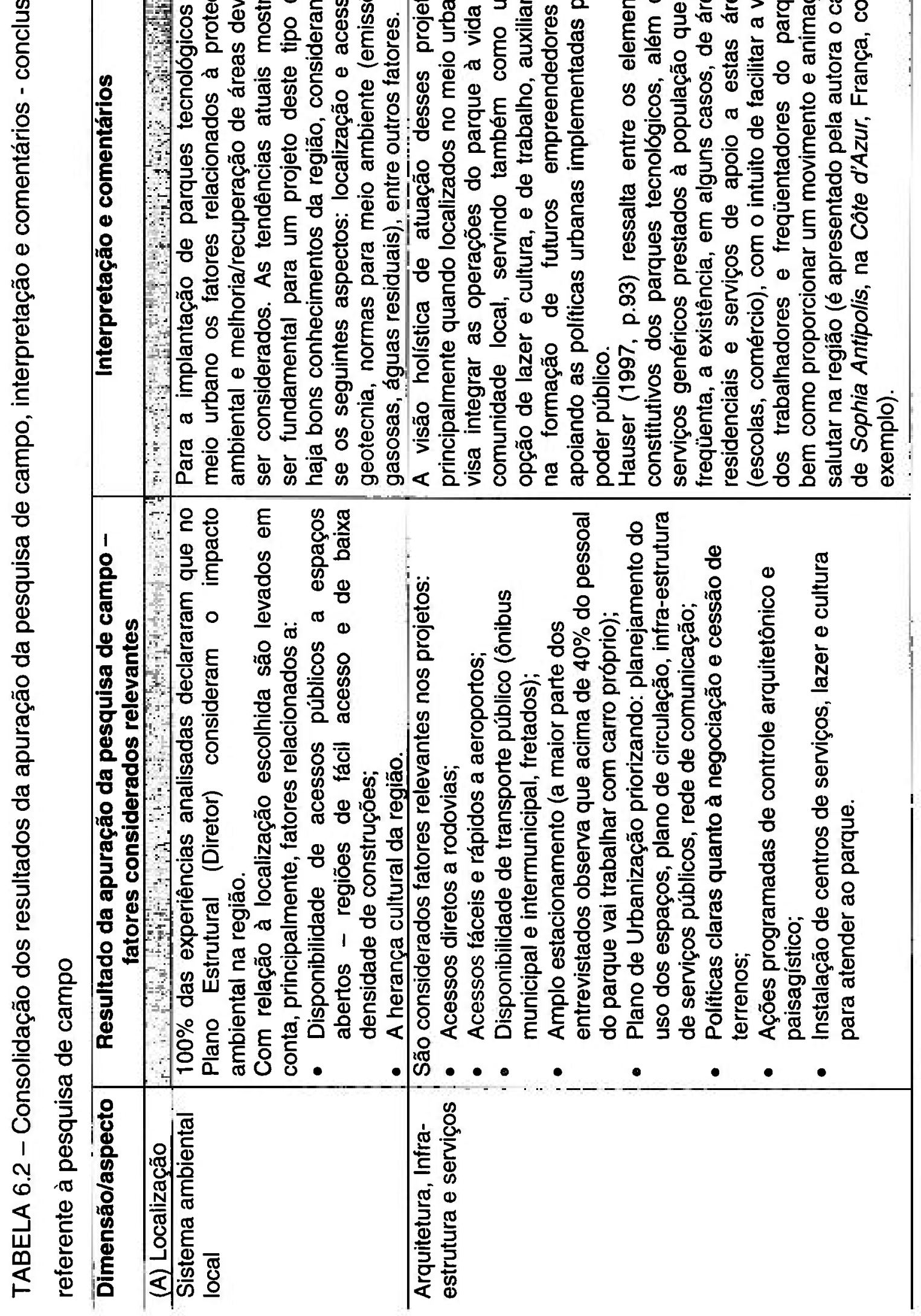




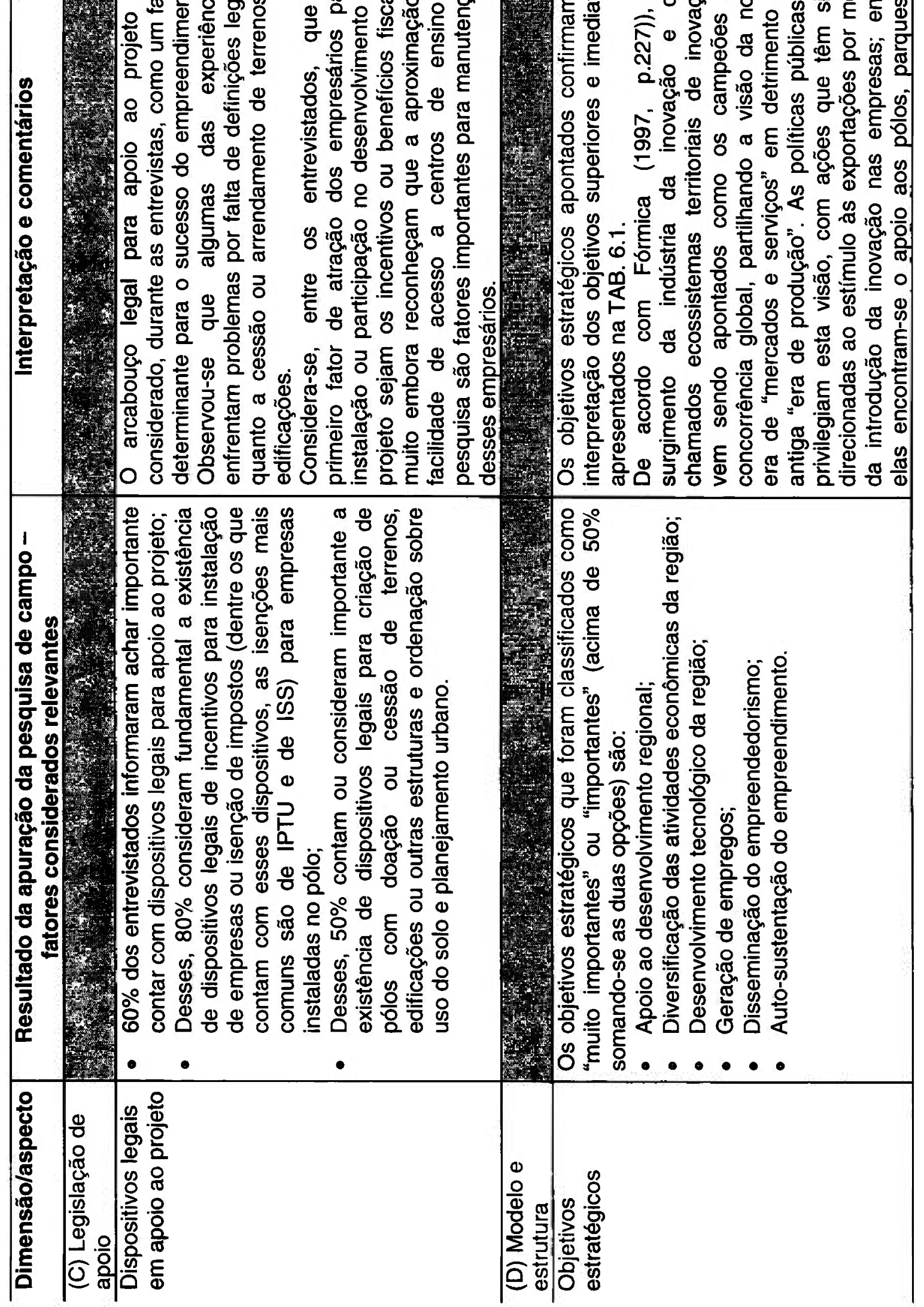




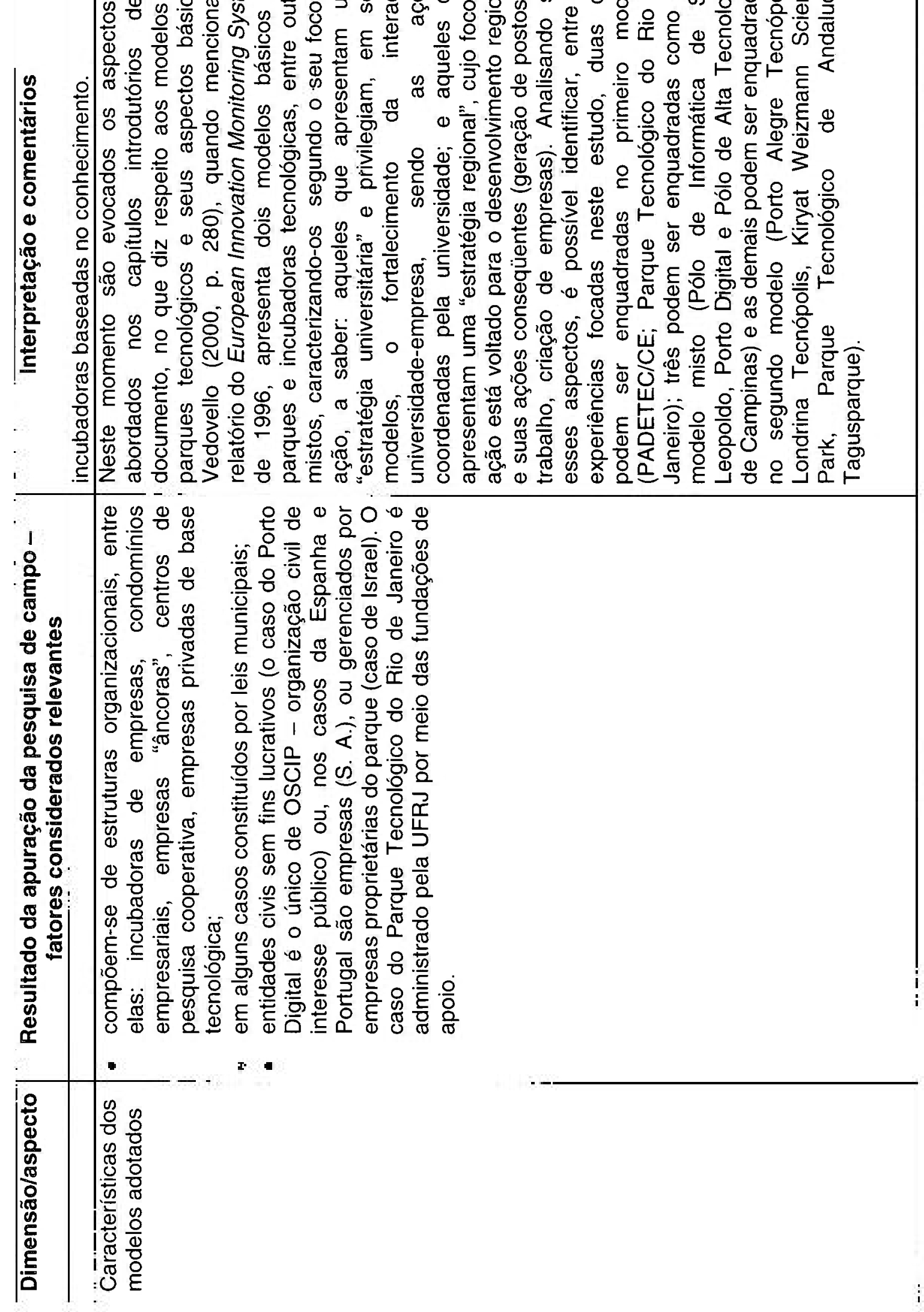




\begin{tabular}{|c|c|c|c|}
\hline & 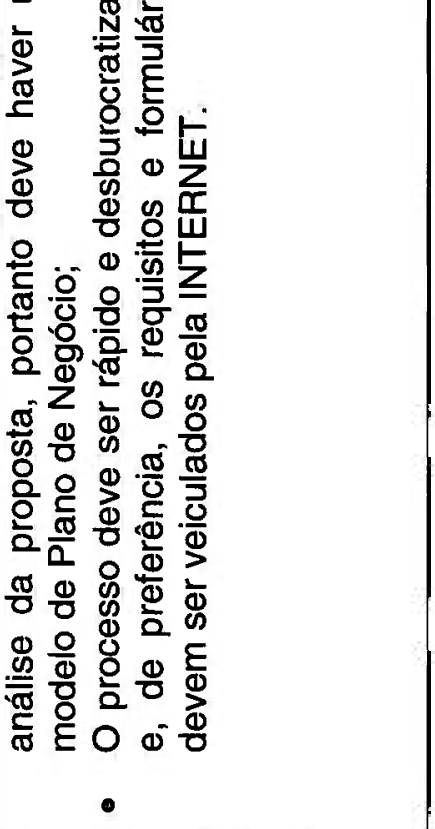 & 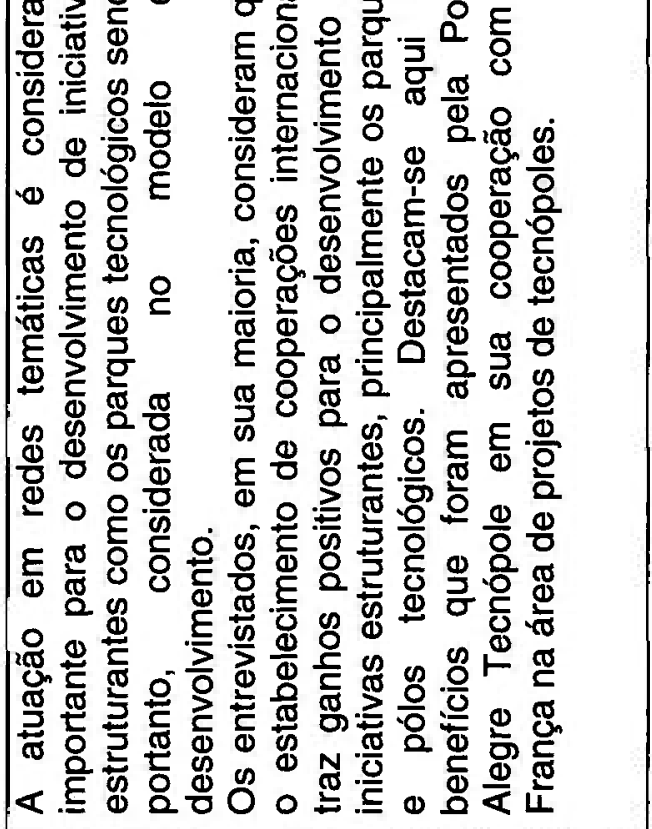 & 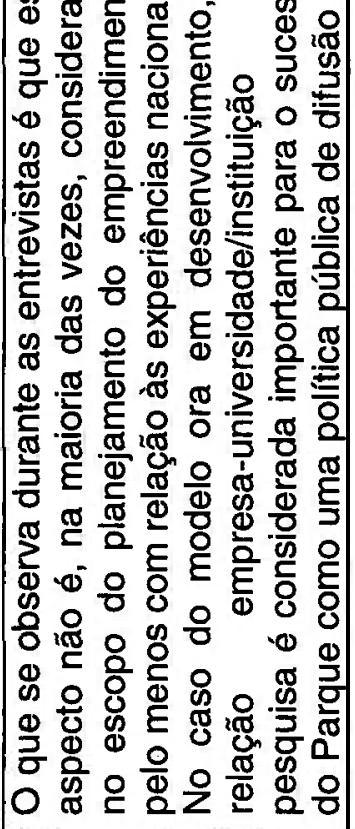 \\
\hline 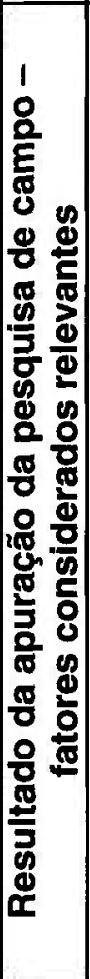 & 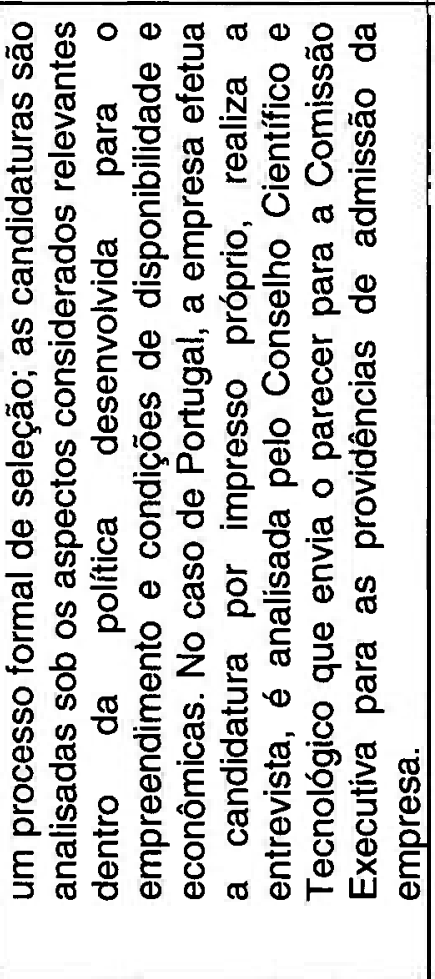 & 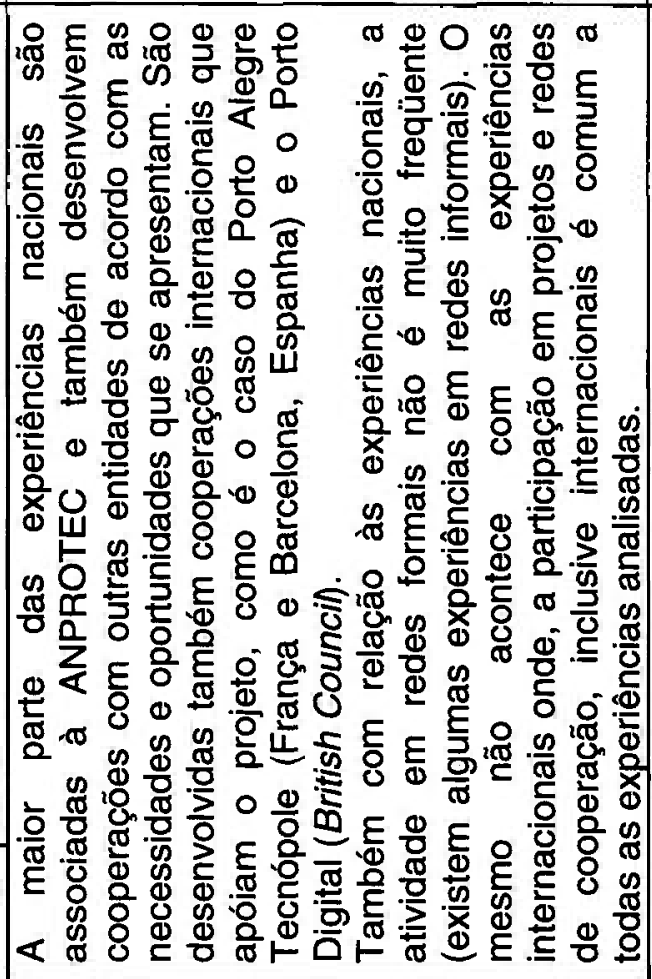 & 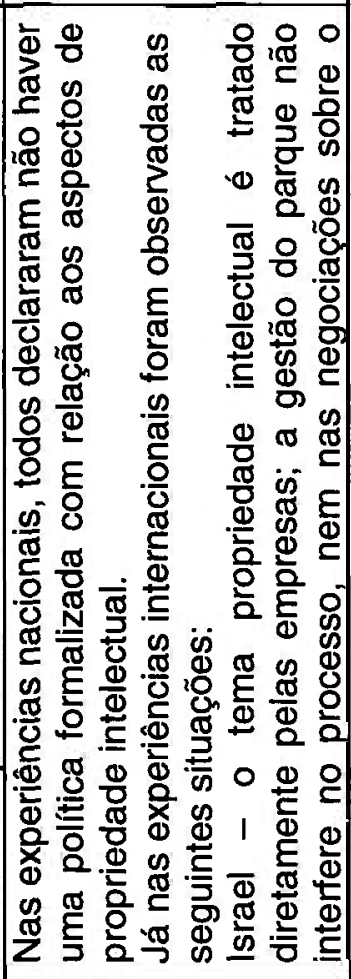 \\
\hline & & 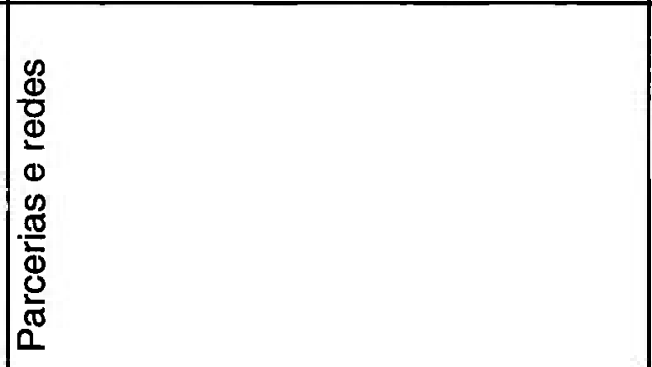 & 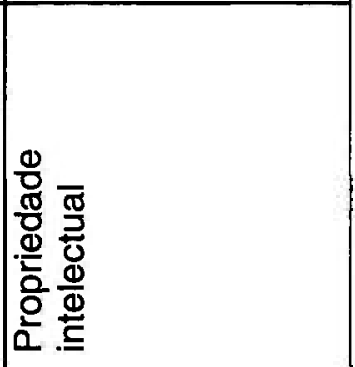 \\
\hline
\end{tabular}




\begin{tabular}{|c|c|c|c|c|c|}
\hline & 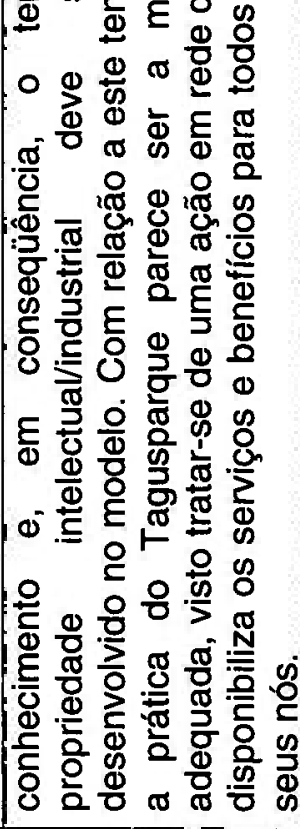 & 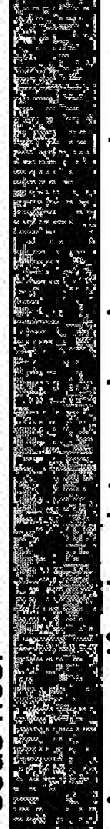 & 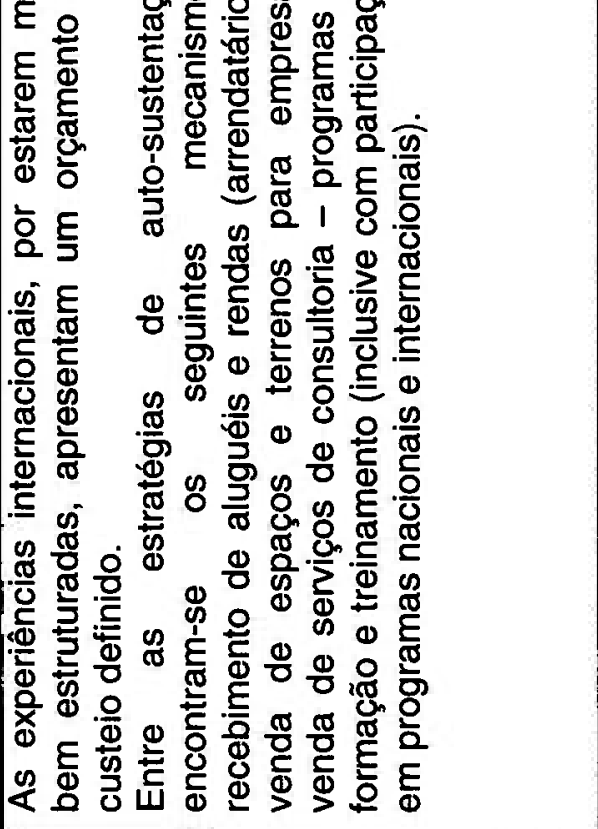 & ma & 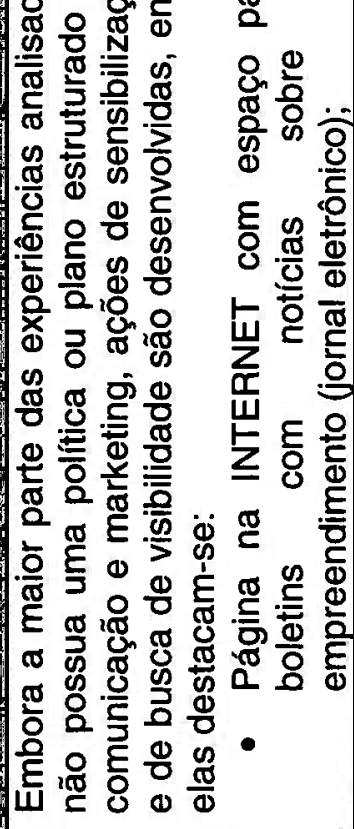 \\
\hline 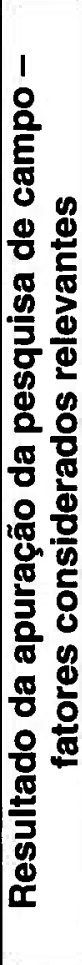 & 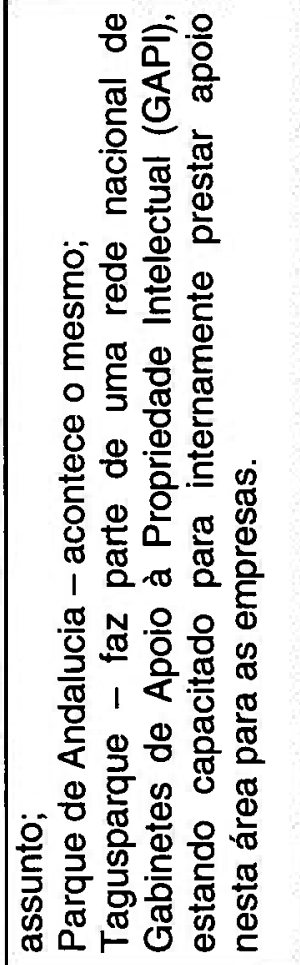 & 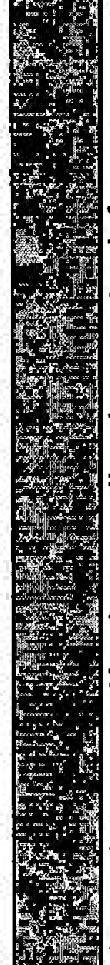 & 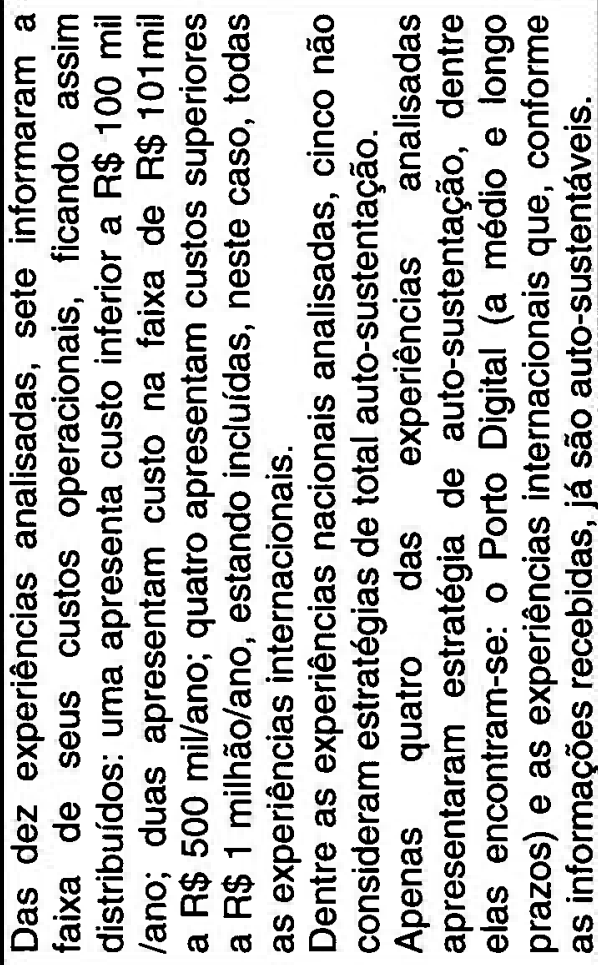 & & 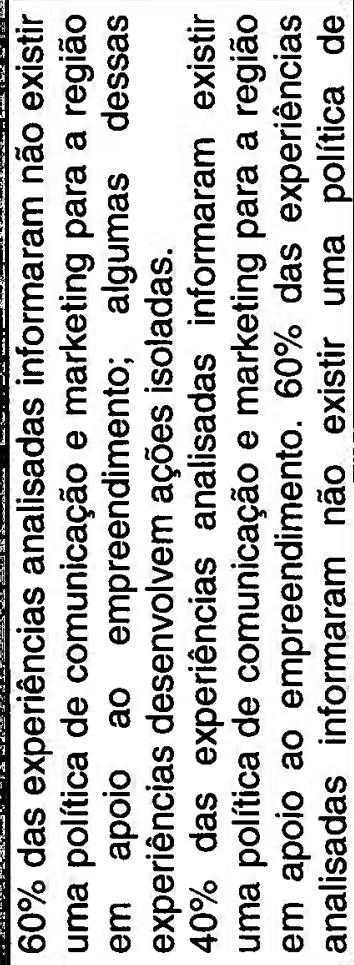 \\
\hline 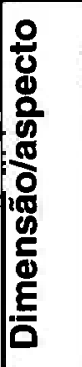 & & 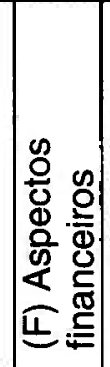 & 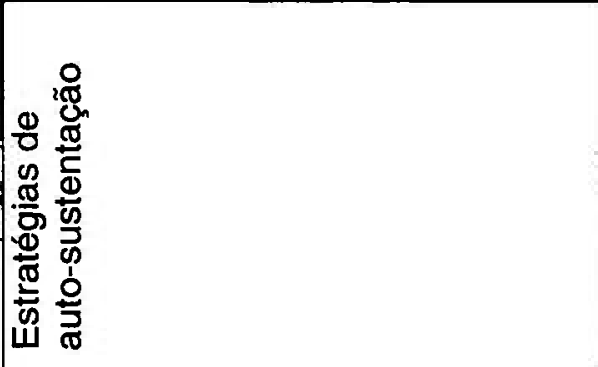 & 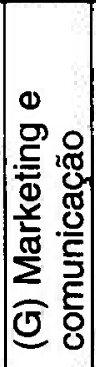 & 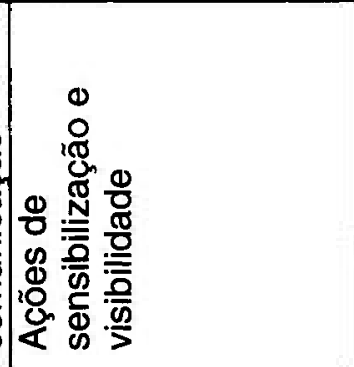 \\
\hline
\end{tabular}




\section{FORMULAÇÃO DO MODELO CONCEITUAL}

"...to maintain a successful development there is a high need of reinventing Science Parks. They must start again being

- an engine of innovation

- a technology transfer and partnering agency

- an incubator center for start-ups and spin-offs.

That means not only to focus on the "hardware", their buildings and square meters. What really brings them to life is the "software", that means the existence of a living network of information, communication and cooperation between the world of science and the business community."

(Klaus Plate')

Neste capítulo são abordados os aspectos relacionados à proposta de um modelo conceitual para um parque tecnológico urbano, particularizando para o Parque Tecnológico de São Paulo, consistente com as observações feitas durante a fase de pesquisa de campo, cujas análises e interpretações foram apresentadas nas TAB. 6.1 e 6.2, bem como decorrentes dos estudos exploratórios, apresentados no capítulo 3 .

São observados, para o desenvolvimento do modelo, os objetivos propostos para este estudo, bem como as questões da pesquisa, apresentados nos capítulos 1 e 2 .

O capítulo foi organizado nos seguintes tópicos:

- O primeiro apresenta um paralelo entre as questões da pesquisa e a concepção de parques científicos e tecnológicos urbanos a partir dos estudos realizados; aborda a formulação da matriz lógica do projeto;

- O segundo desenvolve o modelo conceitual;

- O terceiro apresenta e detalha as estruturas que integram a organização;

- O quarto particulariza o modelo para o Parque Tecnológico de São Paulo.

\footnotetext{
1 PLATE, $K$. Reinventing science parks. In: $V$ WORLD CONFERENCE ON SCIENCE PARKS, October 29-31, 1996, Rio de Janeiro. Proceedings...Rio de Janeiro: AURRP/IASP/ANPROTEC, 1996, p. 358-364.
} 
Este capítulo corresponde à fase 4 da metodologia proposta no capítulo 4 (vide TAB. 4.1).

\subsection{As questões da pesquisa e a concepção de parques científicos e tecnológicos urbanos}

A partir da observação e do conhecimento adquirido durante 0 processo de desenvolvimento da pesquisa, considera-se como principais pressupostos que norteiam os projetos dos parques científicos e tecnológicos urbanos aqueles expostos na TAB. 7.1, que estabelece um paralelo entre esses pressupostos e as questões de pesquisa colocadas por este estudo.

TABELA 7.1 - Pressupostos que norteiam os projetos de parques científicos e tecnológicos urbanos $e$ as questões da pesquisa

\begin{tabular}{|c|c|}
\hline Questões da pesquisa & Pressupostos \\
\hline $\begin{array}{l}\text { Como um modelo de parque tecnológico } \\
\text { pode contribuir para proporcionar } \\
\text { alternativas, baseadas no conhecimento e } \\
\text { na inovação tecnológica, para } \\
\text { desenvolvimento da cidade de São Paulo? }\end{array}$ & $\begin{array}{l}\text { - São iniciativas que apóiam o } \\
\text { desenvolvimento regional, dinamizando } \\
\text { a atividade económica local por meio } \\
\text { de: } \\
\text { - formação e crescimento de empresas, } \\
\text { - aumento das atividades comerciais e de } \\
\text { exportação baseadas em produtos e } \\
\text { serviços com alto valor agregado, } \\
\text { e gerando emprego e renda; } \\
\text { - São iniciativas que envolvem } \\
\text { empreendimentos imobiliários que } \\
\text { possam oferecer a infra-estrutura } \\
\text { necessária e que tornam compatível } \\
\text { esta estrutura com o ambiente urbano e } \\
\text { seus planos de desenvolvimento e } \\
\text { diretor; } \\
\text { - São iniciativas que incorporam em seus } \\
\text { planos o apoio ao desenvolvimento } \\
\text { sustentável e a recuperação de áreas } \\
\text { degradadas ou economicamente } \\
\text { deprimidas nas cidades. } \\
\end{array}$ \\
\hline $\begin{array}{l}\text { Como um modelo de parque tecnológico } \\
\text { pode aproveitar a alta densidade de } \\
\text { instituições de ensino e pesquisa existente } \\
\text { na região, de forma a contribuir com } \\
\text { iniciativas "estruturantes"2 para a } \\
\text { organização da sociedade local, frente aos } \\
\text { desafios do novo paradigma do } \\
\text { conhecimento? }\end{array}$ & $\begin{array}{l}\text { São iniciativas que pressupõem uma base } \\
\text { cientifica e tecnológica de apoio; que } \\
\text { estabelecem ou otimizam, por meio de } \\
\text { estruturas organizacionais formais ou } \\
\text { informais, a disseminação do } \\
\text { conhecimento, do meio acadêmico para o } \\
\text { meio empresarial. }\end{array}$ \\
\hline
\end{tabular}

2 "Essas iniciativas se caracterizam por serem intervenções localizadas e especificas, terem o poder de modificar um conjunto de grande amplitude da realidade a partir da ação sobre seus aspectos parciais, e serem formuladas com base num conjunto de axiomas definidos a partir das características das transições de paradigmas, do novo paradigma e do domínio considerado." (Spolidoro, 1997) 


\begin{tabular}{l|l}
\hline \multicolumn{1}{c|}{ Questões da pesquisa } & \multicolumn{2}{c}{ Pressupostos } \\
\hline para um parque tecnológico urbano, como & estimulam essa sinergia compreendem: \\
instrumento para estimular a sinergia entre & - incubadoras de empresas de base \\
os atores demandantes e ofertantes de & tecnológica ou outros arranjos ou habitats; \\
conhecimento e inovação tecnológica? & - estruturas para a gestão da interação \\
& universidades/centros de pesquisa e \\
empresas; & - estruturas para proporcionar ações de \\
& treinamento e formação para a gestão \\
& empresarial e técnica. \\
\hline
\end{tabular}

Construindo o modelo a partir dos pressupostos apresentados, seguese a estruturação da matriz lógica proposta para o projeto do Parque Tecnológico de São Paulo, à luz do exposto na TAB. 6.1. A TAB. 7.2 apresenta a referida matriz, considerando a sua inserção nas políticas públicas governamentais, nos diversos níveis, e relacionadas à região.

TABELA 7.2 - Matriz Lógica proposta para o Parque Tecnológico de São Paulo

\begin{tabular}{|c|c|}
\hline Missão & $\begin{array}{l}\text { Ser uma iniciativa dinamizadora de ações baseadas no conhecimento, em } \\
\text { prol do desenvolvimento sócio-economico da região metropolitana. }\end{array}$ \\
\hline Visão & $\begin{array}{l}\text { Ser referência nacional como modelo de parque tecnológico disseminado } \\
\text { no tecido urbano. }\end{array}$ \\
\hline $\begin{array}{l}\text { Objetivo } \\
\text { superior }\end{array}$ & $\begin{array}{l}\text { Apoiar políticas públicas municipais, estaduais e federais, voltadas para o } \\
\text { desenvolvimento regional baseado no conhecimento, por meio da criação } \\
\text { de habitats que estimulem a articulação entre governo, academia e capital } \\
\text { e que promovam a sua integração ao meio urbano. }\end{array}$ \\
\hline $\begin{array}{l}\text { Objetivos } \\
\text { imediatos }\end{array}$ & $\begin{array}{l}\text { Sócio-econômicos: } \\
\text { - Estimular a criação de empresas de base tecnológica, com produtos e } \\
\text { - serviços com alto valor agregado; } \\
\text { - com as açón valor agregado; } \\
\text { - Estimular a instalação de empresas de alta tecnologia na região, } \\
\text { alterando sua vocação econômica; } \\
\text { - Estimular a criação de empregos qualificados na região; } \\
\text { Legais: } \\
\text { - Definir arcabouço legal para implantação e operacionalização do } \\
\text { - Parque; } \\
\text { - empcar condições e instrumentos legais para estimular a instalação de } \\
\text { - Buscar condiçães e instrumentos legais para a flexibilização das } \\
\text { atividades de pesquisadores de universidades e centros de pesquisa } \\
\text { nas empresas; } \\
\text { Academicos e de interação universidades/centros de pesquisa-empresa: } \\
\text { - Sedimentar e ampliar a interação universidade/centros de pesquisa- } \\
\text { empresa, na região, por meio de estruturas e ações de estímulo à } \\
\text { criação de mecanismos de apoio à inovação na empresa; } \\
\text { - Disseminar a cultura do empreendedorismo; apoiar a criação de } \\
\text { disciplinas relativas ao tema nos cursos de graduação e pós- } \\
\text { graduação; } \\
\text { - Contribuir para a articulação dos agentes locais de inovação por meio }\end{array}$ \\
\hline
\end{tabular}




\begin{tabular}{|c|c|}
\hline & $\begin{array}{l}\text { de redes; } \\
\text { Comunicação e visibilidade: } \\
\text { - Criar e operar programas para sensibilização da comunidade e dos } \\
\text { formadores de opinião, visando captar o interesse e esclarecê-los a } \\
\text { respeito das oportunidades que podem ser geradas a partir das ações } \\
\text { implementadas pelo Parque Tecnológico; } \\
\text { - Criar um programa de marketing institucional; } \\
\text { Desenvolvimento urbano e meio ambiente: } \\
\text { - Criar um projeto que busque a integração entre o Parque Tecnológico } \\
\text { e a cidade; } \\
\text { Criar um projeto que atraia a animação urbana para seu interior, } \\
\text { criando um ambiente de multifuncionalidade; } \\
\text { Criar um projeto que esteja de acordo com as normas ambientais } \\
\text { vigentes. }\end{array}$ \\
\hline $\begin{array}{l}\text { Resultados } \\
\text { esperados }\end{array}$ & $\begin{array}{l}\text { Sócio-econômicos: } \\
\text { - Aumento do número de micro, pequenas e médias empresas de base } \\
\text { tecnológica criadas na região; } \\
\text { - } \quad \text { Aumento do movimento comercial (faturamento) de empresas } \\
\text { geradoras de produtos com alto valor agregado na região; } \\
\text { - Aumento do movimento de exportações de produtos com alto valor } \\
\text { agregado na região; } \\
\text { - Incremento na oferta de postos de trabalho qualificados na região. } \\
\text { - } \quad \text { Criação de leis e incentivos fiscais em apoio ao Parque e a suas } \\
\text { atividades de atração de empresas; } \\
\text { - Aumento do número de pesquisadores atuando ou apoiando as } \\
\text { atividades das empresas de base tecnológica instaladas na região; } \\
\text { Acadêmicos e de interação universidade/centros de pesquisa-empresa: } \\
\text { - Criação de estruturas e mecanismos de incentivo à cooperação } \\
\text { academia-empresa } \\
\text { - Implantação e incremento de disciplinas relacionadas ao } \\
\text { empreendedorismo nas instituições de ensino, nos diversos niveis, } \\
\text { instaladas na região; } \\
\text { - Aumento do número de alunos empreendedores. } \\
\text { Comunicação e visibilidade: } \\
\text { - Incremento no número de inserções na mídia relacionadas ao Parque; } \\
\text { - Criação de eventos para captar o interesse da comunidade local para } \\
\text { o Parque; } \\
\text { Criação de eventos para captar o interesse de representantes das } \\
\text { esferas governamentais e de empresários para o Parque; } \\
\text { Participação e promoção de eventos internacionais para captar o } \\
\text { interesse de outros países para a cooperação (e negócios) com o } \\
\text { Parque e suas empresas. } \\
\text { Desenvolvimento urbano e meio ambiente: } \\
\text { - Recuperação de áreas degradadas ou economicamente deprimidas da } \\
\text { região, por meio da implantação dos "nós" disseminados no meio } \\
\text { urbano, a partir do Parque. }\end{array}$ \\
\hline Impactos & $\begin{array}{l}\text { Políticos e sócio-econômicos: } \\
\text { - Alavancagem das políticas de desenvolvimento regional, nas diversas } \\
\text { esferas; } \\
\text { - Melhoria nas condições de vida da população local; } \\
\text { - Benefícios para a economia da região; } \\
\text { - Geração de tributos para o desenvolvimento de programas }\end{array}$ \\
\hline
\end{tabular}




\begin{tabular}{|c|c|}
\hline & $\begin{array}{l}\text { governamentais; } \\
\text { - } \quad \text { Possibilidade de replicar o modelo para outras regiões de interesse; } \\
\text { Visibilidade da região: } \\
\text { - Maior divulgação positiva da região no país e no exterior; } \\
\text { - Captação de interesse para a região. } \\
\text { Acadêmicos: } \\
\text { - Valorização da atividade acadêmica; } \\
\text { - } \quad \text { Aumento da experiência em atividades de cooperação } \\
\text { - } \text { universidade/centros de pesquisa-empresa; } \\
\text { Desenvolvimento da cooperação e intercâmbio internacional. } \\
\text { - Valorização de bairros e regiões da metrópole; } \\
\text { - Recuperação de áreas degradadas; } \\
\text { - Contribuição para a paz social. }\end{array}$ \\
\hline $\begin{array}{l}\text { Ações/ } \\
\text { Pressupostos } \\
\text { relevantes }\end{array}$ & $\begin{array}{l}\text { - Articulação dos poderes públicos para apoio ao desenvolvimento do } \\
\text { modelo e para o estabelecimento de políticas de incentivo à instalação } \\
\text { de empresas de base tecnológica na região; } \\
\text { - Captação de suporte financeiro para o projeto, por meio de fontes } \\
\text { nacionais e internacionais, públicas e privadas; } \\
\text { - Competente arcabouço legal para apoio às ações do projeto; } \\
\text { - Estabelecimento de políticas de incentivo ao empreendedorismo nas } \\
\text { universidades e centros de pesquisa; } \\
\text { - Competente política de marketing e de comunicação; } \\
\text { - Fortalecimento e ampliação das relações internacionais; } \\
\text { - Desenvolvimento de ações em redes temáticas; } \\
\text { - Benefícios claros para as universidades e centros de pesquisa de } \\
\text { - Aorma a estimular a sinergia entre os atores do processo; } \\
\text { - benefícios. }\end{array}$ \\
\hline Beneficiários & $\begin{array}{l}\text { - O poder público da região, por meio do apoio às políticas de } \\
\text { desenvolvimento económico e social; } \\
\text { - Sócios ou associados ao parque; } \\
\text { - Comunidade técnico-científica que gravita em torno do projeto; } \\
\text { - Empreendedores e inventores independentes com idéias tecnológicas } \\
\text { inovadoras; } \\
\text { - Graduados e pós-graduados pelo aumento da oferta de postos de } \\
\text { trabalho qualificados; } \\
\text { - Comunidade residente na região pelo aumento do movimento } \\
\text { comercial; } \\
\text { Comunidade carente em regiões adjacentes que se torna alvo de } \\
\text { programas de inclusão social promovidos com o apoio do } \\
\text { empreendimento. }\end{array}$ \\
\hline
\end{tabular}

\subsection{As características e estruturas de negócios inseridas no modelo e suas} relações com os atores envolvidos

O modelo conceitual ora proposto foi elaborado tomando por base três pilares que se apresentaram importantes para o sucesso das experiências analisadas durante a pesquisa de campo e pelas informações obtidas nos estudos exploratórios, a saber: a dinâmica das relações entre os atores 
envolvidos, a inserção e relação com o meio urbano e as características das empresas e respectivos estágios de desenvolvimento; este último aspecto está relacionado às prioridades focalizadas nas políticas regionais para 0 desenvolvimento. Em decorrência, constrói-se o modelo conceitual do parque com base em três conceitos:

- Conceito 1: refere-se às relações entre os atores envolvidos, baseando-se nos modelos do "Triângulo de Sábato" e da "Hélice Tríplice" (Erno-Kjolhede et al.,2001; Leydesdorff \& Etzkowitz apud Santos \& Ichikawa, 2002; Viale \& Campodall'Orto, 2002; Etzkowitz, 2002) sob os aspectos relacionados aos atores envolvidos e suas relações (governo-empresa-universidade/centros de pesquisa) e utilizando, como inspiração, o modelo de "parque tecnológico dinâmico" idealizado por Bolton (1997);

- Conceito 2: refere-se aos estágios de desenvolvimento das empresas e respectivas formas de instalação e permanência no parque;

- Conceito 3: refere-se à proposta de disseminação das ações do parque no meio urbano.

\subsubsection{Conceito 1: a dinâmica das relações entre os atores}

De acordo com Bolton (1997), os parques científicos e tecnológicos podem ser classificados como "estáticos" ou "dinâmicos", apresentando as seguintes características para cada uma das classificações:

- "Estático" - é similar a um espaço industrial, porém com prédios e instalações bem estruturadas e projetadas; buscam como arrendatários empresas baseadas no conhecimento;

- "Dinâmico" - é projetado dentro de um conceito de crescimento do negócio. Tem por objetivo criar massa crítica de indústrias baseadas no conhecimento que se instalam na região, ou, pelo menos, formam clusters. Também objetiva manter uma ligação com os centros locais de ensino superior e de pesquisas, de forma a dinamizar as ações de transferência de conhecimento.

O modelo de Bolton (1997), apresenta essas relações dinâmicas entre os atores envolvidos como um sistema concêntrico, com três círculos, onde são 
representados três grupos de atividades (incubadora ou centro de inovação; empresas maduras e micro e pequenas empresas baseadas no conhecimento; atividades de pesquisa e desenvolvimento de empresas e instituições). A incubadora localiza-se no círculo mais interno, a partir do qual os negócios são irradiados para o círculo intermediário. $O$ círculo externo contém os laboratórios públicos e privados de pesquisa e desenvolvimento, incluindo os laboratórios da universidade. Esses laboratórios irradiam ações para os círculos interiores, num movimento constante, na forma de contratos de pesquisa, alianças estratégicas e spin-offs. Existem também os atores externos aos círculos concêntricos que mantêm vínculos com os componentes do sistema, entre eles a comunidade empresarial local. A conexão com a universidade é realizada por meio de programas ou projetos tecnológicos e de ações de estímulo ao empreendedorismo (formação e treinamento).

O modelo apresentado neste estudo inova com relação ao de Bolton (1997) pela inserção e proposição de: Centros de Pesquisa Cooperativa no círculo médio; pela ampliação dos atores externos aos círculos concêntricos; pela irradiação também de ações de formação e treinamento, incluindo aquelas voltadas para o estímulo ao empreendedorismo. Reúne quatro grupos de atividades no seu contexto: as atividades do centro incubador de empresas tecnológicas que se encontra em sua área (no caso do Parque Tecnológico de São Paulo considera-se o Centro Incubador de Empresas Tecnológicas CIETEC); as atividades das empresas graduadas ou maduras e micro e pequenas empresas (MPEs), externas ao sistema, baseadas no conhecimento, bem como instalações de pesquisa e desenvolvimento de grandes corporações em parceria com instituições de pesquisa instaladas na região, chamadas aqui de "Centros de Pesquisa Cooperativa"; e as atividades do Parque Tecnológico propriamente dito - entidade que suporta as ações previstas no modelo. Na FIG. 7.1 é apresentado graficamente o modelo, aproximando-o para a situação proposta para o Parque Tecnológico de São Paulo. 
Segue-se a tipologia dos atores e formas de relacionamento previstos no modelo conceitual:

- Universidade - base do conhecimento para o modelo e geradora de um meio ambiente propício às relações entre os atores; tem papel importante, social e económico, no contexto da sociedade do conhecimento; conta, geralmente, com estruturas, centralizadas ou dispersas, formais ou informais, que buscam viabilizar a interação universidade-mercado-governo; particularizando para o modelo do Parque Tecnológico de São Paulo, no capítulo 3 foi feita a caracterização da Universidade de São Paulo e Institutos de Pesquisa localizados na região (IPEN, IPT, Butantan, entre outros);

- Outros centros de ensino e pesquisa externos ao campus que aderirem ao Parque - uma das propostas do modelo conceitual é que o parque sirva como elemento irradiador, para a região de influência, propagando uma "onda" ações em rede (alianças estratégicas, pesquisas cooperativas, ações de formação e treinamento conjuntas, joint-ventures, clusters, entre outras) com outras instituições de ensino e pesquisa que se instalem na região ou que estabeleçam relações formais com o parque;

- Centros e institutos de pesquisa do campus - também estão na base de conhecimento do modelo; mantêm relações próximas com o mercado, por meio de desenvolvimento de produtos e serviços tecnológicos e de ações em redes tecnológicas e de informação; contam, geralmente, com estruturas, formais ou informais, que buscam viabilizar a interação universidade-mercado-governo; a caracterização dos Institutos que se localizam no campus da Universidade de São Paulo encontra-se no capítulo 3; 


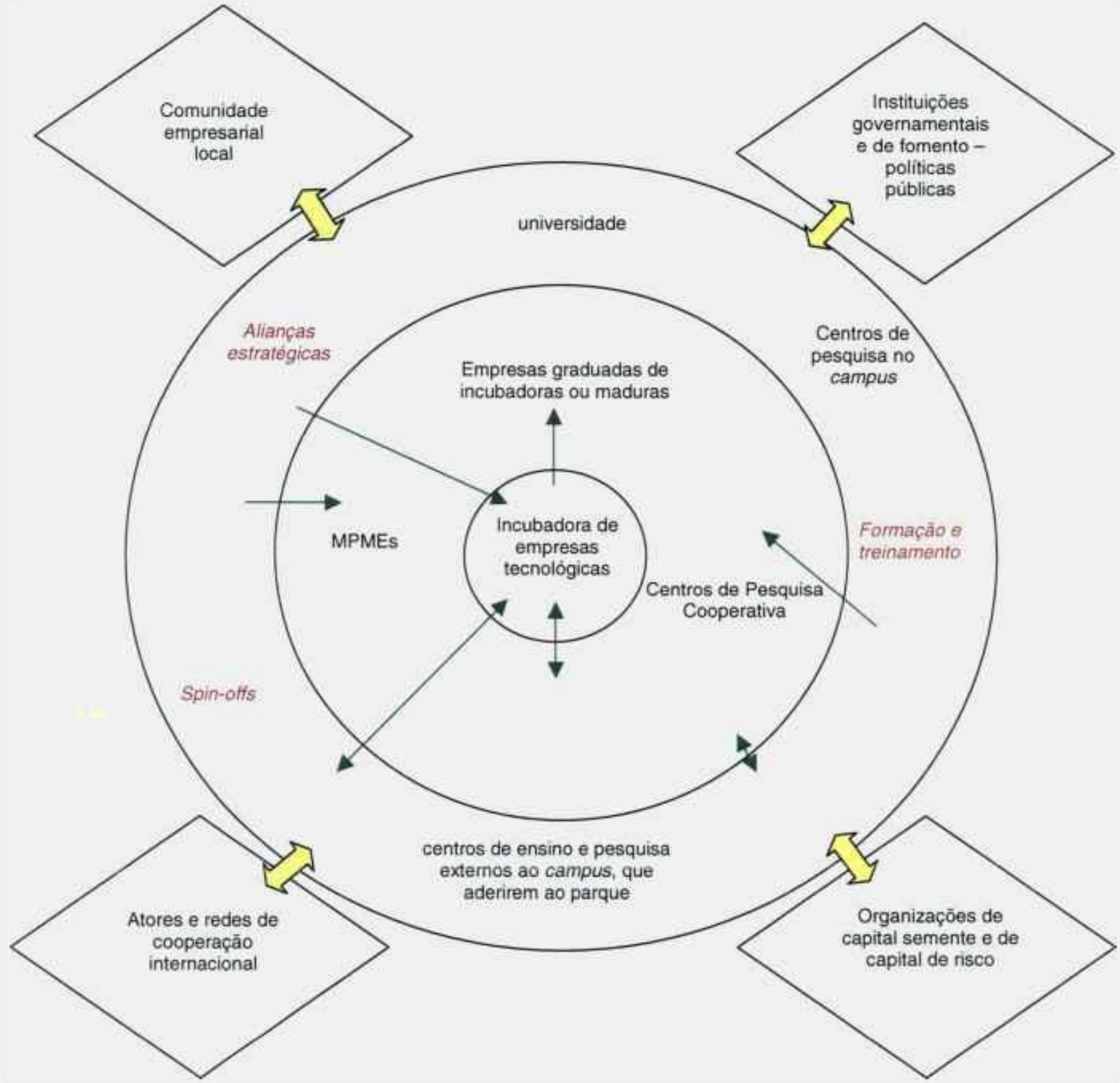

FIGURA 7.1 - Modelo Conceitual do Parque Tecnológico - relações entre os atores 
- Incubadora de empresas tecnológicas - "organização que abriga empresas cujos produtos, processos ou serviços resultam de pesquisa científica, para os quais a tecnologia representa alto valor agregado." (ANPROTEC \& SEBRAE, 2002). O Centro Incubador de Empresas Tecnológicas - CIETEC encontra-se caracterizado no capítulo 3;

- Empresas graduadas de incubadoras ou maduras - "organização que passa pelo processo de incubação e que alcança desenvolvimento suficiente para ser habilitada a sair da incubadora...A empresa graduada pode continuar mantendo vínculo com a incubadora na condição de empresa associada." (ANPROTEC \& SEBRAE, 2002);

- MPMEs (micro, pequenas e médias empresas) - empresas de base tecnológica, ou que atuem com vistas ao desenvolvimento de novos produtos ou processos, que se instalam na área do Parque ou que mantenham associação formal com este;

- Centros de Pesquisa Cooperativa - "instituições criadas para promover a aproximação entre atividades de $P \& D$ e suas aplicações no setor produtivo. Tais instituições reúnem, em geral, empresas, centros de $P \& D$ e instituições governamentais, não apenas servindo de elo de ligação entre a pesquisa e produção, mas também assumindo a iniciativa de patrocinar projetos de $P \& D$, bem como os investimentos necessários à sua utilização prática. Essas instituições, que podem se constituir como empresas, têm, em geral, os seguintes objetivos: realizar pesquisas, desenvolvimentos $e$ adaptações de tecnologias; prestar serviços tecnológicos; e promover a industrialização pioneira dos produtos e processos resultantes de seus projetos." (Cassiolato, 1996)

- Instituições governamentais e de fomento - instituições (nos níveis municipal, estadual ou federal) responsáveis pela formulação e condução políticas públicas que vislumbram no conhecimento a base para o desenvolvimento sócio-econômico e cultural de uma região. A essas instituições somam-se as agências de fomento à 
pesquisa e ao desenvolvimento que, por meio de programas específicos, destinam recursos financeiros, com ou sem retorno, em apoio às atividades de cooperação entre universidades-centros de pesquisa-empresas, com vistas a estimular a inovação tecnológica no meio empresarial;

- Comunidade empresarial local - organizações de classe, empresas e outras entidades representantes do meio empresarial, atuantes na região ou mesmo em nivel nacional, que compreendem a aplicação sistemática do conhecimento como fonte de vantagem competitiva (nos aspectos de inovação tecnológica, capacidade produtiva e qualidade de gestão e organização do trabalho) no mercado globalizado;

- Atores e redes de cooperação internacional - ações de cooperação internacional (em ciência \& tecnologia, qualidade de gestão, organização do trabalho e desenvolvimento urbano e regional), como veículo de acesso ao conhecimento disponível e de incremento de investimentos de empresas internacionais em P\&D no país, que objetivam, além de intercâmbio científico, a realização de programas ou projetos conjuntos, focalizados em propósitos bem definidos, de interesse dos partícipes. São utilizados, entre outros, mecanismos de participação em redes de pesquisa e de informação científica e tecnológica internacionais ${ }^{3}$;

- Organizações de capital semente e de capital de risco: organizações que atuam com: "capital semente" ("seed capital") "quase sempre pequenos montantes de capital fornecidos para transformar uma boa idéia num produto ou serviço comercializável. Pode estar ligado ao desenvolvimento do produto, mas raramente envolve o marketing inicial. É a forma mais arriscada de capital de risco dado que o conceito, a tecnologia, o empreendedor e o mercado ainda não têm provas dadas." (GESVENTURE, 2003);

3 "É evidente e necessária a relação entre modernização do perfil de cooperação internacional e participação crescente do setor privado. A cooperação internacional em CT\&l poderá facilitar o acesso do setor empresarial brasileiro aos circuitos internacionais de $P \& D$, os quais, para boa execução de suas atividades, fortalecerão sua demanda por recursos humanos altamente qualificados e pela produção interna de conhecimento." (Mello \& Cylon, 2001) 
"capital de risco"- "financiamento de capitais próprios fornecido normalmente a empresas jovens e não cotadas para permitir que comecem a se desenvolver ou que se expandam. Estes fundos permitem à empresa ter uma base para conseguir financiamentos bancários adicionais e são uma fonte barata de capital nos estágios menos avançados do negócio porque os dividendos podem ser adiados até que a empresa comece a dar lucro." (GESVENTURE, 2003);

- Spin-offs: "empresas geradas a partir de atividades de pesquisa realizadas no meio acadêmico, cujos resultados são transferidos ao setor empresarial pela mediação de arranjos específicos (empresas de base tecnológica, incubadoras, entre outros)."(Cassiolato, 1996);

- Alianças estratégicas: ações interinstitucionais, formais ou informais, que podem resultar em contratos ou convênios de P\&D, na formação de redes, nucleadas ou polinucleadas, ou mesmo em clusters tecnológicos, cujo objetivo final é a disseminação do conhecimento entre os partícipes e dos benefícios decorrentes desta interação, com vistas ao incremento da competitividade ${ }^{4}$

- Formação e treinamento: ações de apoio ao aprendizado nas áreas de ciência \& tecnologia, qualidade de gestão, organização do trabalho e empreendedorismo, coordenadas pelo Parque, tendo como executores as instituições ou associações entre instituições que integram 0 ambiente. São previstas associações ou participação em redes de ensino e treinamento externas ao ambiente.

O caráter dinâmico da proposta se traduz por meio das relações, movimentos e animação do ambiente, provocados pelos atores e respectivas

\footnotetext{
${ }^{4}$ Lundvall (2000a, 2000b, 2000c, Lundvall apud Cassiolato, 1996), em seus escritos sobre política de inovação e gestão do conhecimento na nova economia do conhecimento, aponta para a necessidade de estímulo à formação de redes densas de empresas e de empresas com instituições baseadas no conhecimento, com vistas a incrementar as políticas de busca da competitividade e criar benefícios para indivíduos, empresas e economias nacionais. Com relação a este tema, também Drucker (1999) comenta: na economia do conhecimento, indivíduos, empresas e economias nacionais gerarão riqueza na proporção da sua capacidade de aprender; "faça associações... a capacidade de fazer associações pode ser inata e fazer parte do mistério que chamamos de gênio".
} 
ações, conforme definidos anteriormente. Este movimento (traduzido na FIG. 7.1 por setas) contribui para a constante atualização dos seus membros, bem como auxilia no processo de aumento da "produtividade do conhecimento" (Drucker, 1999), ou seja, aumenta o rendimento daquilo que é conhecido e aprendido, por meio das associações e relações estabelecidas.

\subsubsection{Conceito 2: Estágios de desenvolvimento das empresas e respectivas} formas de instalação e permanência no parque

Conforme foi visto no item anterior, este modelo privilegia a criação de mecanismos que possam estimular a sinergia entre os centros locais de ensino superior e de pesquisas com as empresas. Ele tem por objetivo proporcionar a criação de uma massa crítica de empresas baseadas no conhecimento que se instalam na região ou, pelo menos, que formem clusters. Apoiando os programas e políticas públicas regionais (no caso "Programa Desenvolvimento Local", da Prefeitura de São Paulo e os programas de apoio ao desenvolvimento do Estado de São Paulo: "Atendimento Empresarial", "Programa de Desenvolvimento e Competitividade (PDC)" e "Programa de Desenvolvimento Industrial (PDI)"), que visam, entre outros objetivos, o desenvolvimento do empreendedorismo e a geração de postos de trabalho, este modelo formula uma proposta que se baseia no crescimento do negócio. Portanto, muito mais do que constituir-se num local propício à implantação de empresas bem colocadas no mercado ou grandes empresas (multinacionais), o modelo proporciona a criação de um habitat de inovação, onde empresas de base tecnológica, em diversos estágios de desenvolvimento podem conviver, estabelecer associações e trocar experiências e conhecimentos.

$\mathrm{Na}$ FIG. 7.2 é apresentado um diagrama dos estágios que apóiam o modelo de crescimento do negócio ora proposto. Nesta figura, estão inseridos os aspectos e estágios que envolvem negócios criados a partir de pesquisas e aplicações desenvolvidas no âmbito de instituições de ensino e pesquisa, a saber: estágios do desenvolvimento de produtos; estágios de desenvolvimento do negócio; arranjos que abrigam os negócios em seus diversos estágios, dimensões das instalações nos estágios que são passiveis de arrendamento; tempo de permanência dos negócios e tipo de serviços prestados às empresas.

Neste ponto, é preciso caracterizar o arranjo "condomínio empresarial" que não foi definido no item anterior, bem como os sub-arranjos pertinentes ao 
Centro Incubador de Empresas Tecnológicas (a caracterização de "parque tecnológico" foi feita no capítulo 3):

- Condomínio empresarial - a ANPROTEC (ANPROTEC \& SEBRAE, 2002) define em seu glossário "condomínio empresarial" como "conjunto de pequenas empresas circunscritas a uma mesma região, organizada de forma contratual, que se unem para viabilizar soluções econômicas e sociais e investimentos planejados; prédio em que estão localizadas várias empresas que compartilham áreas comuns". A definição, no caso deste modelo, tem um sentido um pouco ampliado, visto que a junção de empresas graduadas ou estabelecidas no mercado, não se dá apenas para compartilhar uma infra-estrutura de alto nível, mas também para: criar possibilidades de associações e de compartilhamento de conhecimentos e aprendizado entre empresas, usufruir dos serviços técnicos e de gestão proporcionados pela gerência do parque, usufruir dos benefícios decorrentes da convivência com o habitat acadêmico;

- Pré-incubação: "programa de incentivo para o surgimento de novas empresas, sobretudo na área tecnológica, garantindo também formas de aumentar suas chances de maturação e consolidação futura no mercado."(ANPROTEC \& SEBRAE, 2002);

- Empresas residentes: "organização que desenvolve produtos ou serviços inovadores, está abrigada em incubadora de empresas, passa por processo de seleção e recebe apoio técnico, gerencial e financeiro de rede de instituições constituída especialmente para criar e acelerar o desenvolvimento de pequenos negócios."(ANPROTEC \& SEBRAE, 2002);

- Incubadora sem paredes - organização que suporta empresas que desenvolvem produtos ou serviços inovadores, sendo que essas empresas não estão instaladas fisicamente na incubadora; trata-se de um processo de incubação por fornecimento de serviços e apoio especializado.

Na FIG. 7.2 pode-se observar ainda a inserção de categorias de serviços prestados aos incubados ou associados ao Parque. São apresentadas 
duas categorias de prestação de serviços: a primeira, com base no conceito de "full service provider", ou seja, a atuação como fornecedor completo de senviços, compativel com os estágios pré-incubação e incubação, quando as empresas, ainda em formação, necessitam de apoio, seja nos aspectos relacionados à gestão empresarial, seja nos aspectos de gestão do conhecimento; a segunda pressupõe um estágio de desenvolvimento e maturação, onde são requeridos serviços eventuais de apoio em gestão empresarial e gestão do conhecimento.

As "dimensões das instalações" e "tempo de permanência" colocados na FIG. 7.2 são deduzidos da observação de experiências, podendo ser alterados em função das contingências e objetivos dos projetos.

\subsubsection{Conceito 3: Disseminação das ações do parque no meio urbano}

A proposta que se coloca com relação ao conceito 3 , refere-se à disseminação das ações e benefícios do parque tecnológico no meio urbano. As experiências observadas e os estudos exploratórios realizados revelam situações de localização de parques científicos tecnológicos que parecem evoluir para uma maior participação dos empreendimentos na vida da comunidade da região que os abriga (como é o caso, por exemplo, do Pólo de Informática de São Leopoldo e do Porto Digital).

O presente modelo propõe um passo além da idéia de estruturação de um parque urbano, na concepção que se conhece e que foi abstraída das experiências analisadas durante a pesquisa de campo, com uma região delimitada por muros, reais ou virtuais; o modelo prevê a criação de um núcleo gestor do parque, composto por algumas de suas estruturas organizacionais, e a disseminação deste parque no meio urbano, pela ocupação de áreas disponíveis (na maior parte das vezes degradadas ou economicamente deprimidas) por conglomerados de empresas e serviços (incluindo lazer e cultura), cujas ações estão associadas ao núcleo gestor. 


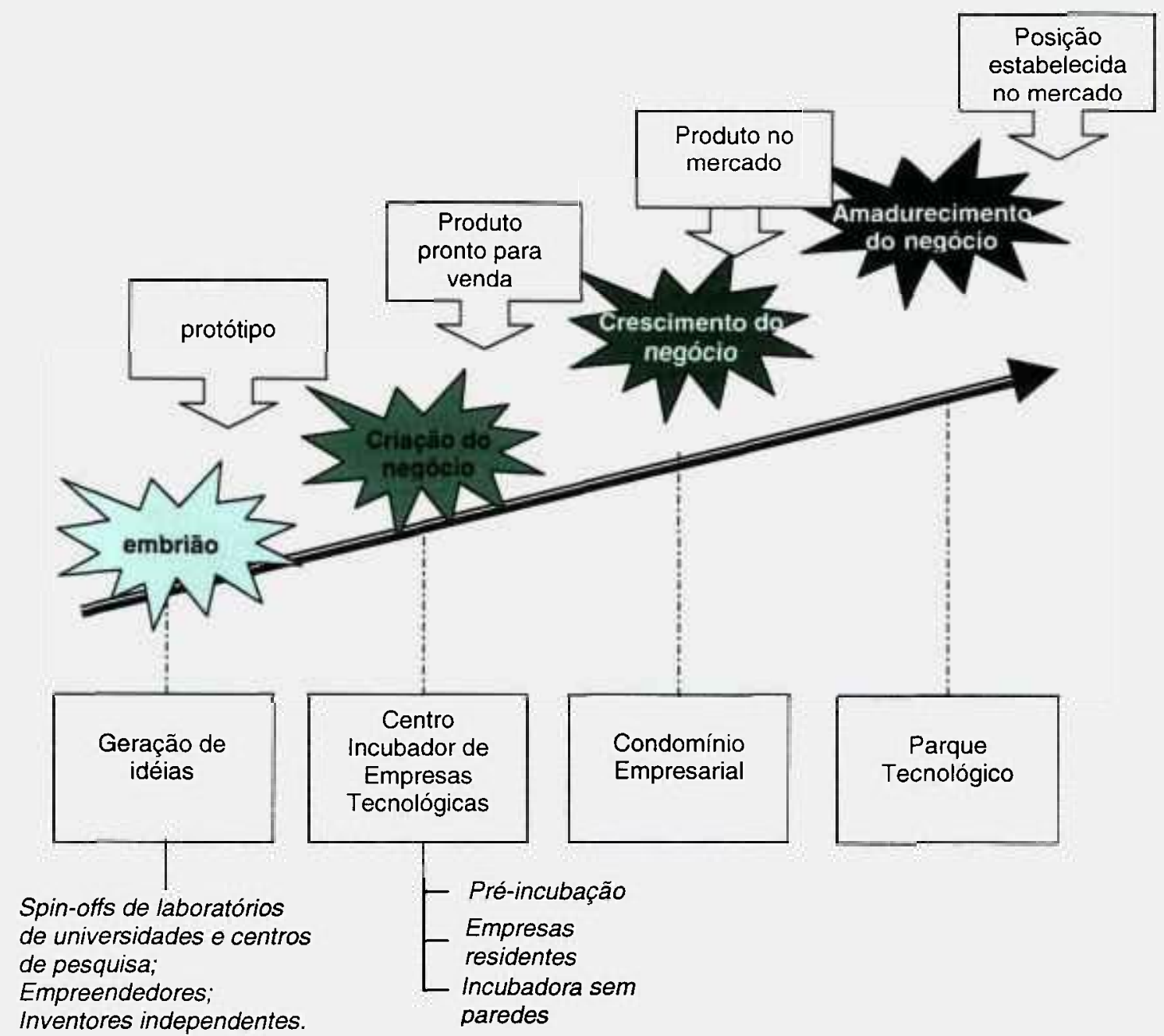

Áreas para

\section{Dimensão das \\ instalações}

\section{Tempo de} permanência

Tipo de serviços

prestados

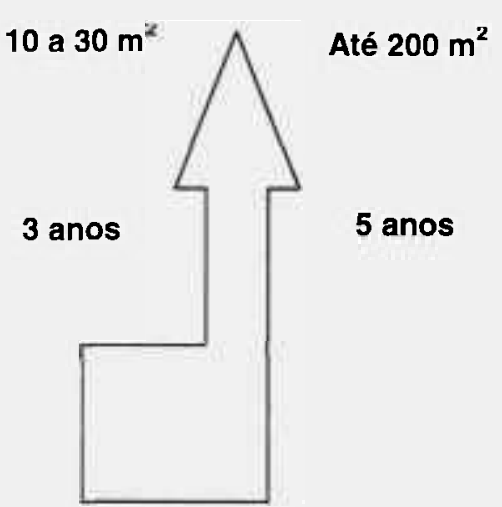

"Full service provider"

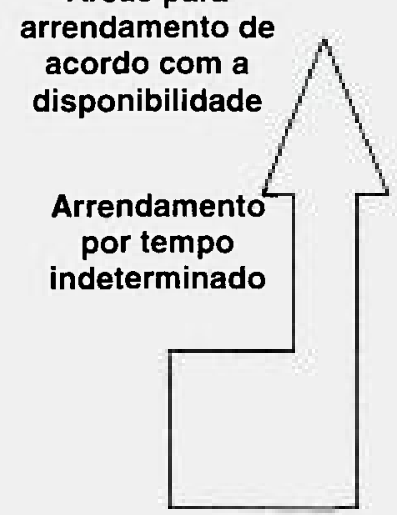

Serviços de apoio opcionais

FIGURA 7.2 - Diagrama dos estágios que apóiam o crescimento do negócio

$\mathrm{O}$ advento do núcleo gestor dá um caráter modular ao projeto, visto que numa primeira fase, a implantação desse núcleo pode se dar com recursos captados em programas e agências de fomento e, possivelmente, pela 
associação com empresas privadas, criando, desta forma, um ambiente de experimentação e visibilidade do modelo, o que ocasionará a captação de interesse para as fases de implantação posteriores (disseminação no tecido urbano).

No item 7.3, a seguir, são detalhadas as estruturas que integram a proposta de modelo conceitual de organização do parque.

\subsection{Estruturas que integram a organização}

Voltando ao início deste capítulo, recupera-se a abordagem sobre as estruturas que melhor se integram à proposta do modelo conceitual. Como já foi comentado anteriormente, considera-se para fins deste estudo que as estruturas organizacionais que estimulam a sinergia entre os atores envolvidos compreendem: incubadoras de empresas de base tecnológica; estruturas para a gestão da interação universidades/centros de pesquisa e empresas; estruturas para proporcionar ações de treinamento e formação técnica e para a gestão empresarial. Na FIG. 7.3 são apresentadas as estruturas propostas para o modelo conceitual do parque, considerando-se os conceitos apresentados no item 7.2.

A estrutura da FIG. 7.3 contempla os pressupostos abordados anteriormente, a saber:

- A incubadora de empresas de base tecnológica - agregando negócios ou promessas de negócios tecnológicos nos estágios de pré-incubação; incubação de empresas residentes, e incubadora sem paredes (empresas associadas);

- Estruturas para a gestão da interação universidade/centros de pesquisa-empresa: o condomínio empresarial e os centros de pesquisa cooperativa e os serviços de apoio às empresas no que tange às relações com o meio acadêmico; representações ou instalações de agências de fomento à pesquisa e à inovação tecnológica e de secretarias e órgãos governamentais de C\&T e desenvolvimento econômico; clusters de negócios tecnológicos;

- Ações de treinamento e formação técnica e em gestão empresarial - promoção, contratação e organização de cursos, eventos e outras iniciativas em apoio à comunidade do parque, com vistas a potencializar o sucesso das empresas no mercado bem como difundir e estimular o empreendedorismo. 
O Parque Tecnológico é composto por um núcleo de operação e por estruturas externas, estas últimas representando a disseminação do parque no tecido urbano. No núcleo estão concentrados os principais serviços e a gestão do Parque Tecnológico, enquanto que as estruturas externas consistem em empreendimentos privados que são associados ao parque.

Segue-se a típologia das estruturas do modelo conceitual do Parque Tecnológico.

- Núcleo do parque tecnológico - estrutura caracterizada por uma limitação territorial bem definida, podendo estar localizado em terrenos e campi universitários ou de centros de pesquisa ou ainda em regiões próximas, contando com infra-estrutura física adequada ao uso das instalações que abriga; contempla prédios para uso comum tais como: auditório, salas de reunião; áreas para exposições; serviços de escritório e de comunicações; serviços de conveniência e áreas de convivência; áreas para recepção, secretaria e gestão do núcleo; conta com uma equipe de gestão, sendo responsável pela coordenação executiva das ações e serviços do parque;

- Incubadora de empresas de base tecnológica - definida no item 7.2, inclusive a concepção e tipos de negócios a serem abrigados; conta com um gerente ou coordenador, que se reporta à coordenação executiva do Núcleo do Parque Tecnológico, e com pequena infraestrutura de secretaria e recepção; todos os serviços e suporte são fornecidos por contratos firmados pelo Núcleo do Parque Tecnológico;

- Condomínio empresarial - estrutura caracterizada pelo arrendamento, por tempo determinado, de prédios ou módulos em prédios, localizados em terrenos do Núcleo do Parque Tecnológico, a empresas de base tecnológica, graduadas de incubadoras ou já existentes no mercado; conta com um gerente ou coordenador, que se reporta à coordenação executiva do Núcleo do Parque Tecnológico, e com pequena infra-estrutura de secretaria e recepção; todos os serviços e suporte são fornecidos por contratos firmados pelo Núcleo do Parque Tecnológico; 
- Centros de pesquisa cooperativa - estrutura caracterizada pelo arrendamento, por tempo determinado, de prédios ou módulos em prédios, localizados em terrenos do Núcleo do Parque Tecnológico a empresas, formalmente constituídas ou não, resultantes de cooperação entre centros de P\&D (de universidades e instituições de pesquisa, públicas ou privadas) e empresas, patrocinados (parcial ou integralmente) por instituições ou agências governamentais, que se unem para realizar pesquisas, desenvolvimentos e adaptações de tecnologias, prestar serviços tecnológicos e promover a industrialização pioneira dos produtos e processos resultantes de seus esforços; cada centro conta com um gerente ou coordenador que mantém estreita relação com a coordenação executiva do Núcleo do Parque Tecnológico; a infraestrutura de serviços e suporte são de responsabilidade de cada centro; apenas os serviços comuns são fornecidos, por meio de contratos, pelo Núcleo do Parque Tecnológico;

- Centro de serviços e formação empresarial - unidade que abriga as atividades de apoio à relação universidades/centros de pesquisaempresa, bem como de apoio ao desenvolvimento em gestão empresarial à comunidade do parque; atua como coordenador e contratador e prestador de serviços, por demanda das empresas instaladas no parque, ou mesmo por demandas externas ao parque, nas áreas de: gestão e integração empresarial; gestão da qualidade e ambiental; propriedade intelectual; processos de apoio à inovação e de incremento da produtividade (incluindo serviços de consultoria e de engenharia); acesso a programas resultantes de políticas públicas governamentais e fontes de fomento e de financiamento; contratação e cooperação tecnológica com instituições acadêmicas e de pesquisa (incluindo demonstração de tecnologias e apoio laboratorial à certificação); comercialização e exportação; o centro nucleia as atividades de formação e treinamento do parque, por meio da coordenação, organização ou promoção de cursos e eventos, em diversas áreas do conhecimento, aproximando 0 parque do meio acadêmico local; caracteriza-se por um estimulador 
ao empreendedorismo na região que atua; participa de redes de informação tecnológica e de ensino; mantém estreitas relações, formais ou informais, com os órgãos de interação universidade/centros de pesquisa-empresa das instituições acadêmicas locais;

- Representações de agências de fomento e de órgãos de C\&T espaço ocupado por escritórios de representação de agências de fomento e outros órgãos de C\&T e da área de proteção à propriedade intelectual que, devido à concentração de atores do sistema local de inovação, se interessem em estabelecer-se no parque ou que considerem o parque como um "nó" de redes temáticas conduzidas por essas organizações;

- "Clusters" de negócios tecnológicos - baseados no conceito de "clusters de inovação", conceito este que tem o foco no compartilhamento, por parte das empresas ali instaladas ou associadas, de conhecimento, de aprendizado e de valores sociais; para o presente modelo, os clusters de negócios tecnológicos estão associados ao parque por meio de contratos de prestação de serviços e participação em conselhos gestores; participam dos benefícios, de qualquer ordem, gerados a partir das ações do parque e por meio dos serviços por ele prestados; podem ou não formar redes temáticas entre si, com vistas a otimizar os processos de expansão de empresas com base no conhecimento (high-tech), com alto potencial de atuação nos mercados globalizados; são empreendimentos imobiliários, privados, com forte apoio dos poderes públicos, por meio de legislação de apoio e de incentivos, tendo em vista que integram políticas públicas de desenvolvimento da região.

\footnotetext{
5 "...an innovation cluster is an organizational structure that creates new products and enterprises by means of collective industrial production within restricted geographical boundaries, based on high concentrations of knowledge exchange, interactive learning and shared social values." ...Innovation clusters should be found within science parks, which are administrative structures that are supposed to promote their development (focusing on the most technology-intensive types of industries)." (Bortagaray \& Tiffin, 2000)
} 


\subsection{Propostas para o Núcleo do Parque Tecnológico de São Paulo}

Particularizando o modelo para o caso do Parque Tecnológico de São Paulo, considerando-se a caracterização da infra-estrutura do conhecimento e demais estruturas envolvidas que foi feita no capítulo 3, propõe-se a implantação do núcleo no campus da Cidade Universitária, aproveitando toda a base já existente, incluindo a incubadora de empresas (CIETEC), conforme apontam estudos realizados anteriormente (Zouain et al., 2000, 2001, 2002a, 2002b, 2002d). Leva-se em conta também, neste caso, os movimentos urbanos ocorridos nas regiões circunvizinhas à Cidade Universitária (também comentados no capítulo 3), tendo em vista que o advento dos clusters associados ao parque possa trazer benefícios para as áreas degradadas ou economicamente deprimidas existentes nas regiões próximas.

Com referência à estrutura do núcleo do Parque Tecnológico de São Paulo, sugere-se a formulação conforme caracterizada no modelo proposto, no item 7.3, destacando-se aqui apenas a estrutura do Centro de Serviços e Formação Empresarial e suas ações associadas, conforme se segue:

Centro de Serviços e Formação Empresarial:

Propõe-se estruturar um Centro de Serviços e Formação Empresarial, como unidade do Núcleo do Parque Tecnológico de São Paulo, visando a prestação de serviços para empresas, em geral, e apoio aos empreendedores e empresas associados ao parque. O Centro de Serviços e Formação Empresarial atua, preferencialmente, no engajamento das MPMEs para que as mesmas tornem-se competitivas e possam realizar atividades de comércio exterior, por meio da melhoria da capacitação tecnológica das mesmas e da potencialização de fatores produtivos e de vantagens competitivas em escalas nacional e internacional.

As ações do Centro são desenvolvidas por especialistas e consultores que realizam reuniões de trabalho com segmentos empresariais para discutir e identificar as necessidades e estabelecer procedimentos para atendimento a essas necessidades. São utilizadas as bases de informação já existentes nas instituições parceiras, bem como são realizadas pesquisas complementares, quando necessário, estabelecendo novas bases de informação nas áreas focadas. Também são previstas associações com redes de informação 
tecnológica, nacionais e internacionais. A difusão das informações dá-se por meio de cursos específicos para os setores mais carentes de informações tecnológicas básicas e por prestação de serviços utilizando-se as instalações das entidades parceiras.

Os temas focais presentes na atuação do Centro abrangem: estratégias, políticas, gestão e integração empresarial; gestão ambiental; inovação, produtividade e qualidade (metrologia, normalização e certificação) para a competitividade; investimento e promoção de tecnologia; núcleo de informações gerenciais - informações tecnológicas e sobre políticas governamentais, contratação e comercialização de tecnologia.

Propõe-se que a estrutura do Centro seja organizada em "ações", conforme abaixo especificados:

- Ação de incubação de exportações: com a função de identificar e auxiliar as empresas de pequeno e médio porte a superarem os obstáculos que dificultam as operações de exportação, sejam de ordem tecnológica, comercial ou burocrática, possibilitando o trabalho cooperativo e estabelecendo "massa crítica" para a superação de problemas;

- Ação de demonstração de tecnologia e de treinamento: com o objetivo de promover seminários, cursos, demonstrações de tecnologia, entre outras atividades, que permitam às MPMEs a rápida absorção de tecnologia aos seus processos, produtos e gestão;

- Ação de informação tecnológica: que permita aos empresários conhecer o "estado de arte" no seu segmento de atuação;

- Ação de apoio à elaboração de projetos: que possibilite o desenvolvimento de projetos cooperativos de pesquisa ou 0 aprimoramento de tecnologia para melhoria da competitividade das empresas. Disponibiliza conhecimento específico para a apresentação de projetos às agências de fomento, com vistas à obtenção de recursos, por meio de projetos (agências / USP IPT/IPEN/empresas, bem como outras instituições de ensino e pesquisa no Estado de São Paulo); 
- Ação de serviços tecnológicos: que intermédia a aproximação com laboratórios, equipamentos, instrumentos e serviços, da USP, IPT, IPEN, bem como de outras instituições de pesquisa e ensino, mediante propostas caso a caso, o que permite ganhos de competitividade, seja aferindo os insumos que entram no processo, seja testando em escala de laboratório ou piloto os novos processos ou melhorias, seja certificando a qualidade dos produtos finais;

- Ação de propriedade intelectual e comercialização de tecnologia: com o objetivo de coordenar e apoiar as ações nessas áreas que envolvam as empresas e as instituições vinculadas ao Parque Tecnológico de São Paulo.

O Centro estabelece convênios de cooperação internacional com entidades congêneres para manter-se atualizado tecnológica e gerencialmente e para apoiar as empresas associadas em suas alianças estratégicas com empresas e entidades no exterior.

O reforço e o apoio às políticas públicas de desenvolvimento do Estado de São Paulo podem ser caracterizados pelo estabelecimento de rede de parques tecnológicos, no Estado, coordenando ações de interesse de iniciativas já existentes em outras localidades, bem como utilizando o modelo urbano, ora proposto, como fonte de inspiração para outras regiões urbanas, metropolitanas ou em processo de metropolização. Zouain et al. (2002c) associa as iniciativas de estabelecimento dos habitats de inovação (no caso os parques tecnológicos), como exemplos da hélice tríplice, aplicada ao desenvolvimento regional no Estado, obtido pela disseminação de conhecimento, aprendizado e valores por meio da atuação em rede (podendo esta ser nucleada ou poli-nucleada, de acordo com os aspectos contingentes regionais). 


\section{DISCUSSÃO E LIMITAÇÕES DO MODELO CONCEITUAL}

...Admito de bom grado, que somente a observação pode proporcionarnos um "conhecimento concernente aos fatos" $e$ que "só tomamos consciência dos fatos pela observação". Mas essa consciência, esse nosso conhecimento, não justifica nem estabelece a verdade de qualquer enunciado. Não creio, conseqüentemente, que a Epistemologia deva indagar"...sobre que se apóia nosso conhecimento?..ou mais exatamente, como posso eu, tendo tido a experiência $F$, justificar a descrição que dela faço e preservá-la da dúvida?"

...Presentemente, eu formularia a questão desta maneira: de que modo proceder para melhor criticar nossas teorias (nossas hipóteses, nossas conjecturas), em vez de defendê-las contra a dúvida?"

(Karl Raimund Popper)

No presente capítulo são lançados os tópicos para a discussão (tentativa de falseamento) do modelo formulado no capítulo anterior.

Este capítulo corresponde à fase cinco da metodologia proposta no capitulo 4 (vide TAB. 4.1).

São apresentadas assertivas concernentes ao modelo proposto, relacionadas às questões de pesquisa, para a tentativa de falseamento ou crítica, levantando os aspectos positivos e negativos de práticas e conceitos nele abordados. Neste sentido, são adotados os seguintes procedimentos: comparação com as experiências observadas e analisadas durante a pesquisa de campo, discussão utilizando o conhecimento obtido na fase de estudos exploratórios e de pesquisa bibliográfica, mencionando autores que desenvolveram pesquisas sobre os temas abordados.

As seguintes assertivas, concernentes ao modelo proposto, são colocadas para a tentativa de falseamento ou crítica:

- Primeira assertiva: refere-se à proximidade entre os atores envolvidos

O modelo de parque tecnológico proposto aproveita a disponibilidade local de instituições baseadas no conhecimento, caracterizando-se por valorizar a proximidade entre os atores envolvidos no processo.

- Segunda assertiva: diz respeito às relações com o meio urbano e aos aspectos de desenvolvimento regional 
- modelo proposto apresenta características de apoio ao desenvolvimento de políticas públicas regionais, baseadas no conhecimento, sob os seguintes aspectos: estimula a formação e o crescimento de empresas baseadas no conhecimento (paradigma da sociedade do conhecimento); promove a atração de capital para a região; estimula a revitalização de áreas urbanas degradadas ou economicamente deprimidas; o modelo apresenta como característica de disseminação das ações do parque no meio urbano, a formação de "clusters" de inovação.

- Terceira assertiva: relaciona-se à dinâmica das relações entre os atores envolvidos e às estruturas que promovem essas relações

O modelo de parque tecnológico proposto estimula o estabelecimento de relações entre essas instituições e a sociedade local, focalizando principalmente o desenvolvimento do meio empresarial, por meio de estruturas organizacionais e ações, formais ou informais, promovendo a disseminação do conhecimento e dos benefícios dela decorrentes; caracteriza-se como exemplo dos modelos ternários conhecidos, a Hélice Tríplice e o Triângulo de Sábato.

\subsection{Primeira assertiva: a proximidade entre os atores envolvidos}

\subsubsection{A proximidade dos atores como fator de sucesso dos parques tecnológicos}

Analisando o universo dos parques tecnológicos, pesquisas têm sido conduzidas sobre a interação universidade-indústria no contexto desses habitats (Murphy, 1997; Saxenian, 1996; Vedovello 1996; Vedovello, 1997).

Observa-se que, em uma primeira análise dos efeitos da proximidade física entre os atores, os Parques Tecnológicos têm contribuído, principalmente em regiões onde operam plenamente, para facilitar as ligações de diversas espécies, sobretudo as informais, mais relacionadas a iniciativas pessoais entre os parceiros, privilegiando interesses mútuos e específicos. Inseridas neste contexto estão ações do tipo consultoria, participação em empresas ou pesquisadores fundadores de empresas.

O mesmo não se pode comentar no caso de interações formais, baseadas em atividades de pesquisa e desenvolvimento de universidades e instituições de pesquisa, do tipo cooperativo ou corporativo. Apesar da existência 
nos parques tecnológicos de pesquisas patrocinadas por empresas, bem como a ocorrência de doações financeiras e de equipamentos para a universidade ou instituições de pesquisa, não é possível associar esses eventos à proximidade ou localização das empresas no parque. Acredita-se que a flexibilidade de estruturas e ligações, as ações em redes dinâmicas, bem como a criação de valor para a comunidade da região sejam fatores essenciais para o sucesso das relações entre os atores envolvidos no parque, tornando favorável a proximidade entre eles. Murphy (1997), quando se refere ao Parque Tecnológico de Stanford associado à The Leland Stanford Junior University, uma das mais tradicionais universidades americanas, enxerga a proximidade, nesse caso, trazendo benefícios claros, não só sociais, mas também econômicos, tanto para a comunidade universitária quanto para a indústria que se localiza na região (Palo Alto e adjacências). Faz-se mister, então, a criação de ações de animação e de programas formais que facilitem o acesso às instalações da universidade, promovam a circulação rotineira das publicações da universidade, criem novos tipos de vínculos não acadêmicos (ações culturais e comunitárias, cooperação internacional, entre outros). Nesse sentido, a proximidade física entre os atores, promove um ambiente fertilizador de interação cultural, social e de processos inovadores que contribui para a criação de uma vantagem regional, em detrimento de simples aglomerações espaciais de empresas.

Um relatório preparado por pesquisadores do Instituto Nacional de Pesquisas Científicas da Universidade de Québec, Canadá, que analisa alguns tipos de aglomerações científicas e tecnológicas, entre elas os parques científicos, aponta como um dos fatores de sucesso dessas aglomerações a proximidade geográfica entre os atores (Martineau et al., 1999). Os argumentos para isso são que essa proximidade: promove a consolidação de setores industriais emergentes e facilitam o desenvolvimento de redes de informação e a transferência de conhecimentos ("par le biais des contacts face à face").

\subsubsection{Discussão sobre a primeira assertiva}

As experiências nacionais analisadas são, em sua maioria, muito jovens, principalmente, no que diz respeito àquelas que se caracterizam como parques tecnológicos. Essas, por sua vez, têm sua base de experiência na incubação de empresas, geralmente associada a universidades e centros de pesquisa. Foi observado que a experiência com incubação de empresas cria um 
ambiente fértil para processos de inovação, bem como traz benefícios, e até mesmo uma certa revitalização, das instituições de ensino e pesquisa associadas. Este ambiente de fertilidade deve acontecer também quando os parques estiverem em pleno funcionamento.

Nos casos estrangeiros analisados durante este estudo, apesar da grande experiência e resultados positivos obtidos nos parques, tanto como empreendimentos de negócios como na geração de empresas inovadoras, não é possivel comprovar que a proximidade entre os atores envolvidos seja um fator preponderante na garantia desse sucesso, pois não foram conduzidas pesquisas específicas para este fim, muito embora todos concordem que é fator importante.

O modelo de parque tecnológico ora proposto valoriza a proximidade entre os atores envolvidos no processo, partilhando o princípio de que, apesar de as relações poderem ser facilitadas por modernos instrumentos e mecanismos de comunicação, a proximidade física é fator importante no processo de fertilização cruzada, tão necessária para o sucesso do empreendimento. Esta valorização encontra-se caracterizada em dois níveis, nesta proposta (representados nas FIG. 7.1 e 7.2): pelo do núcleo do parque tecnológico que engloba as atividades dos representantes do tripé governo-empresa-academia, propondo estruturas que caracterizam essas relações; bem como em sua localização, no campus ou próximo a ele, facilitando o contato direto com os diversos departamentos e laboratórios, serviços tecnológicos e gerenciais disponíveis ("hardware" e "software"), criando um ambiente de estímulo à manutenção de relações férteis (sinergia, redes interpessoais) para o desenvolvimento dos novos negócios e para a disseminação do conhecimento, sejam por meios formais ou informais.

8.2 Segunda assertiva: relações com o meio urbano e aos aspectos de desenvolvimento regional

Os aspectos de localização de parques tecnológicos têm sido abordados na literatura, embora poucas são as referências relacionadas à análise de sua localização no meio urbano. Neste item, para conduzir uma discussão no tema de parques tecnológicos e sua inserção no meio urbano, busca-se, em 8.2.1, algumas referências e estudos relacionados ao progresso tecnológicos e seus impactos na questão urbana. 


\subsubsection{Evolução tecnológica e a questão urbana}

O progresso tecnológico tem sido considerado fonte de impacto nas regiões urbanas (principalmente nas metrópoles) tanto nos aspectos de introdução de novas atividades de produção e de consumo, quanto pela eliminação de obstáculos graças ao desenvolvimento das comunicações, contribuindo, portanto, para a descentralização dos centros de produção e distribuição. Observa-se que, em decorrência da evolução tecnológica, diminui a importância de fatores de localização para a indústria, e esta depende, cada vez mais, de mão-de-obra qualificada e infra-estrutura disponíveis no meio urbano'. É oportuno comentar que Castells (1999), no seu livro "Fim de Milênio", traz à tona o debate sobre o impacto da revolução da tecnologia da informação sobre a sociedade: "A tecnologia da informação tomou-se ferramenta indispensável para a implantação efetiva dos processos de reestruturação socioeconômica".

É possível, portanto, abstrair-se que a região urbana ou a metrópole se reestruturam com base em novas relações espaço e sociedade, em parte decorrente dos avanços tecnológicos (tecnologia da informação) em detrimento do antigo paradigma de cidades industriais.

Durante a pesquisa de campo, especificamente estudando a Porto Alegre Tecnópole ${ }^{2}$, em contato com os estudos sobre parques tecnológicos e a metrópole, desenvolvidos no âmbito daquele projeto, ressaltam-se esses novos aspectos espaciais urbanos, e seus impactos nos planos diretores e estratégias territoriais. Ou seja, os planejadores urbanos devem considerar as novas características das indústrias em seus processos e estratégias de ocupação dos espaços nas cidades, estando entre essas características: as novas dimensões das indústrias, principalmente as de base tecnológica, onde a terceirização das atividades, as plantas mais automatizadas e otimizadas em seu espaço, não poluentes, $e$ as reduzidas equipes de trabalho, são características preponderantes; e a necessidade de infra-estrutura de transportes, telecomunicações, comércio, habitação e serviços públicos em geral.

\footnotetext{
1 Remete-se, neste ponto, ao pensamento de Castells (1983, p.54) em seu livro a "Questão Urbana", com relação ao impacto das conquistas tecnológicas sobre as metrópoles; o autor não atribui a formação das regiões metropolitanas apenas ao progresso tecnológico, ..."pois a técnica... é um elemento do conjunto das forças produtivas, que são, elas mesmas, primordialmente, uma relação social, e comportam assim, um modo cultural de utilização dos meios de trabalho".

${ }^{2}$ Esses aspectos relacionados ao uso do espaço urbano no Projeto Porto Alegre Tecnópole são mencionados por Hauser (1997).
} 
Trazendo a discussão mais especificamente para a cidade de São Paulo, foco do modelo em questão, observa-se uma mudança significativa na configuração da atividade industrial no município, com a concentração de empresas inovadoras, o êxodo de plantas industriais menos dinâmicas e a grande quantidade de micro, pequenas e médias indústrias, novas, pela cidade ${ }^{3}$. Como características inovadoras da indústria que passa a ocupar o meio urbano apresentam-se a ocupação de espaços menores e a utilização de serviços avançados e de mão-de-obra especializada. Esse processo de reconversão industrial traz conseqüências espaciais no tecido urbano, visto que as áreas que foram antigamente ocupadas por indústrias que saíram da cidade, podem agora ser novamente ocupadas, porém, esta ocupação também é motivo de preocupação. Os urbanistas externam esta preocupação baseados, principalmente, em dois aspectos: a indústria ou atividades baseadas no conhecimento ou inovadoras são poupadoras de mão-de-obra (ou, pelo menos, utilizam mão-de-obra qualificada, como já foi mencionado anteriormente neste item) e os megaprojetos empresariais que vêm sendo implantados em áreas fora do antigo centro, constituem-se como novas áreas de concentração e polarização, caracterizadas pela monofuncionalidade e baixa densidade de espaços públicos. Com relação a isto, Raquel Rolnik comenta:

"A entrada - dispersa e fragmentada - das novas formas comerciais na periferia não rompe com a dualidade tão constitutiva da cidade, mas tão-somente a repõe, de forma fractal, já que até hoje nada foi feito para integrar e desenvolver (e não dilacerar e substituir) o tecido socioeconômico preexistente." (Rolnik, 2001).

\subsubsection{Localização de parques tecnológicos e sua inserção no tecido urbano}

Nesta etapa coloca-se para discussão: quais são os benefícios decorrentes da implantação de um parque tecnológico no meio urbano? Quem são os beneficiados? Podem os parques tecnológicos tornarem-se enclaves urbanos, ilhas de excelência?

Alguns autores abordam este tema apontando aspectos favoráveis e desfavoráveis à implantação de parques tecnológicos no meio urbano (Giunta, 1996; Hauser, 1997; Spolidoro, 1996, 1997, 2000; Silva, 1996), salvaguardadas

\footnotetext{
${ }^{3}$ Com relação à mudança da configuração da indústria na cidade de São Paulo, Raquel Rolnik (2000a, 2000b, 2001) comenta que São Paulo continua sendo ainda um importante centro industrial, dinâmico, e não uma "metrópole terciária".
} 
as situações peculiares, principalmente àquelas relacionadas à interação desses empreendimentos com o seu meio, favorecendo a urbanidade.

Considera-se que a inserção dos parques tecnológicos (e incubadoras de empresas) no meio urbano pode trazer vantagens para as empresas e para as regiões nas quais se instalam. Essas iniciativas devem se integrar à comunidade da região, beneficiando-se da proximidade com fontes de financiamento, de conhecimento e ensino, de redes de distribuição; e beneficiando o meio urbano em que se inserem pela melhoria da qualidade de vida da área, da renovação de prédios, pelo estímulo à renovação da atividade econômica local (criando uma relação "ganha-ganha").

Ainda com relação aos benefícios, conforme já foi comentando anteriormente, os aspectos de proximidade entre os atores envolvidos no parque ${ }^{4}$ são importantes, porém, devem ser observadas características de localização que apóiem o desenvolvimento dos projetos, bem como enriqueçam a vida da comunidade e promovam uma sinergia profícua no ambiente em que estejam inseridos. No caso de São Paulo, como em muitas outras cidades ou metrópoles brasileiras, para que seja possível a promoção de implantação de parques tecnológicos urbanos, urge a tomada de decisão e algumas iniciativas com relação aos espaços que possam ser selecionados para os projetos. Entre essas iniciativas, encontram-se: a reserva (ou previsão nos Planos Diretores locais) de áreas ou zonas, preferencialmente adjacentes ou próximas às universidades ou centros de ensino e pesquisa; no intuito de desenvolver uma reativação de áreas deprimidas ou deterioradas, identificar e facilitar o acesso a prédios ou terrenos desativados para a implantação das estruturas do parque tecnológico (estando incluídas aqui as incubadoras de empresas); os planejadores urbanos e poderes públicos preverem incentivos (fiscais ou de outra natureza) para a captação de interesse e apoio a esses projetos, ou seja, que os mesmos façam parte de seus discursos e programas, inclusive no que tange à visibilidade dos mesmos para a sociedade.

Por outro lado, aspectos desfavoráveis podem surgir com relação à implantação de parques tecnológicos no meio urbano. Entre esses aspectos encontram-se: uma possível baixa sinergia com o meio urbano, principalmente

\footnotetext{
"Spolidor (2000) comenta que os parques tecnológicos são "laboratórios de criatividade coletiva".
} 
nos casos dos parques tecnológicos implantados nas periferias das cidades (Silva, 1996); as estruturas desenvolvidas nos campi universitários muitas vezes sofrem com barreiras burocráticas e normativas que dificultam o uso do solo ou a disponibilização do mesmo para a iniciativa privada, prejudicando assim o sucesso do projeto.

\subsubsection{Discussão sobre a segunda assertiva}

O modelo de parque tecnológico, disseminado no tecido urbano, propõe algumas soluções para questionamentos colocados pelos pesquisadores com relação ao espaço urbano atual, principalmente no que se refere a grandes centros urbanos.

A fase de disseminação do parque tecnológico no meio urbano pela formação de "clusters" de negócios tecnológicos é uma proposta colocada pelo modelo que relaciona-se ao desenvolvimento urbano. $A$ intervenção de políticas públicas no desenvolvimento e localização desses "clusters" é fator preponderante para o sucesso de ações de apoio à recuperação de regiões degradadas ou economicamente deprimidas da cidade. Consistem também em grande oportunidade para promover o diálogo entre a iniciativa privada e o poder público em prol do desenvolvimento e da recuperação urbana. Ou seja, captar o interesse privado para atuar em projetos que geram lucro e que estejam perfeitamente integrados ao planejamento urbano para as regiões nas quais são implantados, e ainda, que proponham soluções para essas regiões que compartilhem espaços públicos e privados e que considerem as características culturais das comunidades locais.

Sendo assim, não se tornariam esses "clusters" os "robocops inteligentes", mencionados por Rolnik (2001), mas sim empreendimentos que, conforme exposto no capítulo 7 , estariam plenamente integrados ao meio ambiente sócio-cultural e econômico da urbe, orientados por legislação bem definida, contando com serviços públicos e privados e espaços públicos que proporcionem uma animação urbana. Neste sentido, a utilização de áreas ocupadas por antigos galpões industriais e por prédios públicos desativados, contando com projetos de re-urbanização dessas áreas, pode ser um fator de estímulo ao processo de implantação do modelo. No caso de São Paulo, por exemplo, existe uma clara intenção dos poderes públicos de revitalização do antigo centro da cidade e de outras áreas, como a da região do entorno da 
Cidade Universitária de São Paulo, conforme foi apresentado no capítulo 3, sendo este modelo uma possibilidade que pode apresentar soluções para esta questão.

- Programa Desenvolvimento Local da Prefeitura de São Paulo (Prefeitura Municipal de São Paulo, 2002) identifica "cadeias produtivas que são alvos preferenciais de ações de políticas públicas de desenvolvimento local, a saber.

- "Atividades com maior capacidade de geração de empregos;

- Atividades que se caracterizam pela maior capacidade inovadora nas áreas de produtos, projetos, design, engenharia de processos, de gestão e tecnologia da informação, entre outros;

- Atividades pouco ou relativamente desenvolvidas, mas que requerem do poder público iniciativas de apoio e incentivo, particularmente nas áreas de tratamento de resíduos sólidos, reciclagem, saneamento, biotecnologia, desenvolvimento de softwares, entre outros;

- Atividades econômicas de base tecnológica e solidária, que deverão ser implantadas por processo de incubação e financiamento de microempreendimentos, tendo em vista os princípios dos programas Oportunidade Solidária e São Paulo Confia, da SDTS/PMSP;e

- Por último, atividades com potencial exportador."

Observe-se que o modelo ora proposto se coaduna aos objetivos do Programa acima mencionado, tendo em vista que estimula atividades econômicas baseadas no conhecimento, com alto potencial exportador, que proporcionam a geração de empregos atingindo não só empregos não qualificados (no que tange aos serviços básicos e de infra-estrutura), mas também empregos altamente qualificados, que podem absorver a mão-de-obra que vem sendo gerada pelas universidades. Além disso, o modelo incentiva a criação e ampliação de empresas, disseminando o empreendedorismo na região, modificando o quadro de geração de renda.

Outro aspecto importante do modelo está relacionado à criação de uma rede entre os "clusters de negócios tecnológicos" tendo como nó coordenador o Núcleo do Parque Tecnológico de São Paulo. Observe-se que esta associação ao Núcleo, sendo este considerado um projeto de apoio a algumas linhas de políticas públicas, traz benefícios para a cidade, visto que permite a disseminação de conhecimento e experiências adquiridas pelo processo, durante 0 seu desenvolvimento e implantação, a todas as regiões que dele participarem. 


\subsection{Terceira assertiva: a dinâmica das relações entre os atores envolvidos e às estruturas que promovem essas relações}

Especialistas no tema de parques tecnológicos têm desenvolvido estudos para verificar o grau de sucesso desses empreendimentos no que se refere ao aspecto gestão do conhecimento e a relação academia e meio empresarial, como indicador de resultado para apoiar o desenvolvimento regional.

Este tema, analisado sob uma ótica ampliada, não apenas relacionado à atuação dos parques tecnológicos, traz alguns aspectos delicados para sua análise, visto refletir questões tais como as missões das organizações envolvidas. Discute-se, por exemplo, até que ponto a universidade deve envolver-se em desenvolvimentos ou serviços tecnológicos necessários às empresas? Onde são geradas as inovações tecnológicas que são utilizadas nas empresas; elas partem somente de conhecimentos gerados nas universidades e centros de pesquisa?

Durante a pesquisa de campo bem como por meio dos estudos exploratórios, observou-se que, muitas vezes, a inovação, nas empresas, não é gerada a partir da ciência, da academia. Muitas idéias ou invenções são decorrentes, por exemplo, de percepções ou oportunidades apresentadas pelo mercado, melhoramento em produtos, entre outras. Ou seja, a inovação não decorre de um processo linear, mas sim do compartilhamento de um conjunto de conhecimentos que levam a ela, incluindo mercado, design, processos de engenharia, entre outros. A Confederação Nacional das Indústrias, no Brasil, publicou recentemente o relatório "A Indústria e a Questão Tecnológica" (FINEP/CNI, 2002) cujas conclusões permitem abstrair que as empresas brasileiras (apesar de um expressivo aumento na percepção da importância do desenvolvimento tecnológico como estratégia competitiva), em sua maioria, buscam novos produtos, porém não por meio da aproximação com a universidade e centros de pesquisa, mas sim por meio do mercado e de seus fornecedores.

"A aquisição de máquinas e equipamentos é, de longe, a principal atividade promovida pelas empresas para 0 desenvolvimento tecnológico...As estratégias de inovação foram predominantemente realizadas exclusivamente nas próprias empresas, recorrendo-se pouco a parceira com outros atores. Os principais parceiros identificados são os clientes e fornecedores...quase a totalidade das empresas investigadas reconhecem a inovação como estratégia para os seus negócios, embora se possa afirmar também que uma parcela ainda importante não se considera capacitada para a inovação, notadamente no caso das pequenas empresas." (FINEP/CNI, 2002). 


\subsubsection{Modelos ternários e "habitats" de inovação}

São apresentados, a seguir, alguns argumentos para discutir se 0 modelo ora proposto, enquanto habitat de inovação, representa uma proposta de interação entre ciência e tecnologia e sociedade.

Conforme foi visto no item 7.2 (notas de rodapé 3 e 4), o Triângulo de Sábato e a Hélice Tríplice são modelos ternários que representam graficamente as relações entre a academia, o meio empresarial e o governo que, por ações coordenadas consistem em elementos fundamentais para o desenvolvimento na sociedade do conhecimento.

Em fins de 1968, Sábato \& Botana "advogaram a necessidade da inserção da ciência e da tecnologia na própria trama do processo de desenvolvimento ...esse processo resultaria da ação múltipla e coordenada de três elementos fundamentais para $o$ desenvolvimento das sociedades contemporâneas: o governo, a estrutura produtiva e a infra-estrutura cieníficotecnológica" (Plonski, 1995; Sábato \& Botana apud Plonski, 1998). A representação gráfica deste modelo se dá por meio de um triângulo no qual o governo ocupa o vértice superior e as universidades e instituições de pesquisa e as empresas ocupam a base. O Triângulo de Sábato evidencia três tipos de relações: as intra-relações que ocorrem entre componentes de um mesmo vértice; as inter-relações, que se estabelecem deliberadamente entre pares de vértices; $e$, as extra-relações, que se criam entre uma sociedade e o exterior.

A "Hélice Tríplice" de Leydesdorff e Etzkowitz (Etzkowitz, 2002; Santos \& Ichikawa, 2002) trata-se de um modelo conceitual para representar as relações entre o meio acadêmico (incluindo aqui todos os tipos de instituições geradoras de conhecimento), a empresa (desde start-ups de alta tecnologia até grandes corporações multinacionais) e o governo (em seus vários níveis), que difere dos demais, principalmente, por inserir o desenvolvimento econômico (e em decorrência o social) também como uma missão do meio acadêmico. Ou seja, o meio acadêmico passa a ter um papel importante nesse processo, juntamente com os demais atores, promovendo a criação de organizações e ações (programas e políticas) híbridas, das quais os parques tecnológicos e as incubadoras de empresas são exemplos. 
$\mathrm{Na}$ discussão do conceito da Hélice Tríplice, considera-se que o modelo tem por objeto representar a interação entre governo, universidade e indústria, baseando-se em ações governamentais nacionais ou regionais que promovam (ou incentivem) a colaboração entre a pesquisa acadêmica e a indústria, que levam à inovação tecnológica. Os principais instrumentos propostos pelos órgãos governamentais para alcançar essa interação costuma basear-se em ações coordenadas, acordos, e instituições de interface, com apoio econômico público. Discute-se, porém, se este modelo é realmente promotor de colaboração entre a indústria e o meio acadêmico.

Viale e Campodall'Orto (2002), em seus estudos baseados na observação feita sobre as realidades sócio-econômicas e dos sistemas de pesquisa e desenvolvimento dos Estados Unidos e da Europa, propõem uma evolução do modelo da Hélice Tríplice, com o objetivo de demonstrar que relações fortes e bem estruturadas entre o meio acadêmico e o empresarial, que geram bons resultados científicos e tecnológicos são possíveis por meio do estabelecimento de estruturas legais bem definidas e reconhecimento das necessidades do mercado, e não pela intervenção direta de órgãos governamentais públicos.

De fato, observa-se a necessidade de um novo tipo de atuação do setor público, com vistas a criar uma estrutura normativa que estabeleça um ambiente seletivo de incentivos que podem ser indutores da evolução da colaboração, em pesquisa e inovação, entre meio acadêmico e indústria.

\subsubsection{Discussão sobre a terceira assertiva}

Considera-se que o modelo de parque tecnológico ora proposto pode representar os modelos ternários de relação meio acadêmico-meio empresarialgoverno, devido, entre outras, às seguintes características:

- Participam da organização representantes dos três pilares dos modelos ternários: academia, empresa e governo (representado por órgãos governamentais regionais e agências de fomento);

- A atuação entre os três pilares se dá por meio de ações (ou organizações) que promovem e estimulam a interação entre os mesmos, conforme visto no capítulo 7, a saber: a incubadora de empresas de base tecnológica, as estruturas para a gestão da interação academia-empresa (centros de pesquisa cooperativa, 
centro de serviços e formação empresarial, alianças estratégicas) e as ações de treinamento e formação técnica e em gestão empresarial;

- O Condomínio Empresarial e os clusters de negócios tecnológicos, integrantes do modelo, consistem em estruturas intimamente ligadas ao Núcleo do Parque Tecnológico e, portanto, são estimulados pela interação dos atores envolvidos no processo de inovação.

Com relação ao exposto por Viale \& Campodall'Orto (2002), no item anterior, durante a pesquisa de campo, foi observado que iniciativas como as dos parques tecnológicos analisados (entre outros habitats de inovação) dependem de um conjunto de leis e incentivos que permitem captar o interesse da iniciativa privada para os empreendimentos. A atuação dos órgãos governamentais proposta neste modelo prevê 0 apoio à criação de base legal e de incentivos para garantir o sucesso dos projetos. Esta atuação, no entanto, não alcança o âmago do que foi proposto por Viale \& Campodall'Orto (2002) onde a atuação do governo "is to provide legal incentives to correctly direct the decision-making of the basic actors from the botton-up".

Porém, uma discussão maior que é pouco abordada diz respeito às ações legais e incentivos à participação do meio acadêmico, ou seja, como desenvolver também uma "perspectiva social" da ciência. A perspectiva clássica faz com que a gestão das entidades acadêmicas se depare com problemas tais como: uma oposição a aspectos de gestão; o conflito entre a academia clássica e a perspectiva social da ciência: a crescente complexidade da pesquisa, exigindo cada vez mais a atuação dos pesquisadores em grupos de pesquisa multidisciplinares (cooperação versus individualismo) (Erno-Kjolhede et al., 2001).

Esta discussão traz à tona um aspecto importante dos problemas que a gestão de um parque tecnológico e suas estruturas devem enfrentar, no que diz respeito às relações com o meio acadêmico.

Já se começa a admitir que a capacidade de gerar conhecimento e transformar este conhecimento em resultados para a sociedade não é papel tão somente das universidades. Esta realidade vem se transformando na concepção de estruturas organizacionais, no âmbito das universidades, que têm por objetivo gerir a cooperação entre os seus diversos departamentos e o meio empresarial, 
bem como apoiar as políticas públicas regionais por meio da participação em programas e projetos.

Plonski (1999) abordando as relações entre o meio acadêmico e o meio empresarial e suas evoluções, comenta a respeito das últimas tendências com a criação das "universidades empreendedoras" ("entrepreneurial universities") que insere as universidades, e seu papel de excelência acadêmica tradicional, no universo do "mercado do conhecimento". De acordo com Plonski (1999):

“...Essa participação, que caracteriza o capitalismo acadêmico, se dá mediante a comercialização de resultados de pesquisa e a participação nos negócios desenvolvidos por seus docentes e estudantes. Para estimular esses negócios, tais universidades instalam incubadoras de empresas, exploram parques tecnológicos e adquirem posições no capital de novas empresas de base tecnológica intemamente originadas - neste caso, agindo a academia como capitalista de oportunidade (venture capitalist)."

Conscientes dessa realidade, e buscando criar suporte legal para facilitar e incentivar essas relações, alguns países desenvolveram leis de pesquisa e desenvolvimento que regulam, entre outras ações, a participação de pesquisadores e instituições de pesquisa em empresas, a criação de núcleos ou outras organizações de gestão da inovação tecnológica. No Brasil, os esforços desenvolvidos pelo Ministério de Ciência e Tecnologia se traduziram no Projeto de Lei da Inovação (o projeto dispõe sobre medidas de incentivo à pesquisa científica e tecnológica e à inovação, altera o parágrafo primeiro, do artigo segundo da Lei número 8745, de 9 de dezembro de 1993, entre outras providências), muito semelhante à lei francesa para o mesmo fim. A íntegra do projeto enviado ao Congresso Nacional, propõe a flexibilização das relações entre pesquisadores, institutos de pesquisa e empresas privadas no desenvolvimento de novas tecnologias para produtos, processos e serviços. São propostas medidas de incentivo à pesquisa, mudanças na gestão das instituições científicas bem como as ações de estímulo à criação de empresas de base tecnológica.

As principais propostas do Projeto de Lei:

"Instituições de pesquisa: os produtos e processos inovadores a serem obtidos por instituições de pesquisa vão poder ser adotados por empresas privadas interessadas na produção de bens e serviços. As instituições, no entanto, ficam protegidas por mecanismos eficazes de transferência cientifica. 
Propriedade intelectual: será distribuída entre todas as partes envolvidas nas parcerias. As patentes passarão a ser reconhecidas em avaliações de mérito dos pesquisadores, como ocorre hoje com os artigos de publicações científicas. $O$ projeto também garante ao pesquisador participação nos ganhos econômicos auferidos pela instituição com a exploração de suas criações.

Empresas: poderão compartilhar laboratórios e equipamentos com as instituições públicas de pesquisa, mediante remuneração e, também, formar alianças estratégicas - seja com outras empresas, com instituições de C\&T ou com a União. Neste último caso, a União só poderá participar destes empreendimentos se for para a criação de centros considerados de relevante interesse nacional.

Pesquisadores (os lotados em instituições públicas): poderão receber autorização para afastamento dos cargos, caso queiram colaborar com pesquisas em outras instituições ou empresas. Também poderão tirar licença não remunerada se tiverem interesse em constituir, eles próprios, uma $E B T^{5}$. Inventores independentes: suas criações poderão ser adotadas por instituições de pesquisa, visando a elaboração de projetos que tenham possibilidade de industrialização ou utilização por parte do setor produtivo. ${ }^{36}$

\subsection{Limitações e comentários finais sobre a discussão do modelo}

O modelo conceitual de parque tecnológico em meio urbano proposto por este estudo apresenta algumas limitações, entre elas encontram-se:

- Definição de indicadores - pode ser questionada a não definição de indicadores de desempenho quando da formulação da Matriz Lógica proposta no capítulo 7; com efeito, a matriz lógica foi utilizada para tornar claros os objetivos, ações e resultados esperados com a implantação de iniciativas estruturantes, no caso o parque tecnológico, em apoio a políticas públicas regionais voltadas para 0 desenvolvimento baseado no conhecimento. Não é propósito deste estudo tratar das fases de controle e de ações corretivas relativas à implantação do modelo;

\footnotetext{
${ }^{5}$ EBT - Empresa de Base Tecnológica

${ }^{6}$ Disponivel em: <

www.mat.gov,br/comunicacao/textos/default.asp?cod_tipo $=18$ cod_texto $=2650>$. Acesso em: 15 fev. 2003.
} 
um conjunto de indicadores será de fundamental importância para criar uma base de informações para a revisão de etapas de planejamento e de estratégias para atingir os objetivos propostos pela entidade gestora do parque;

- Modelo de gestão - não são apresentadas propostas à cerca do modelo de gestão a ser adotado; foram observadas diversas formatações nesse sentido durante a pesquisa de campo, entre elas: a formação de uma empresa; Organização Social (OS), Organização da Sociedade Civil de Interesse Público Federal (OSCIP), entidade civil sem fins lucrativos, departamento ou subordinação à universidade. Observa-se, porém, que a definição do modelo de gestão depende de fatores contingentes e dos responsáveis pelo empreendimento. Sugere-se, no entanto, que modelos que reflitam independência para gestão do parque e que representem adequadamente os diversos atores e interesses envolvidos são os que melhores possibilidades de sucesso apresentam, segundo diversos gestores entrevistados;

- Localização do Parque Tecnológico de São Paulo - por tratar-se de um modelo conceitual, não foram sugeridos locais para a localização do Parque Tecnológico de São Paulo, na sua fase de disseminação no tecido urbano. O modelo indica a localização do Núcleo ou no campus universitário ou em área a ele adjacente. No entanto, no capítulo 3 são apresentados alguns estudos sobre os movimentos urbanos na cidade de São Paulo e nas regiões próximas ao campus da Universidade de São Paulo, que podem ser utilizados para iniciar estudos específicos para a localização dos "clusters" de negócios tecnológicos, propostos no modelo;

- Arcabouço legal em apoio ao parque tecnológico - não é objetivo deste estudo desenvolver proposta de um arcabouço legal em apoio ao parque tecnológico, embora este tenha sido considerado, durante as entrevistas, como um fator determinante para o sucesso do empreendimento. Observou-se que algumas das experiências enfrentam problemas por falta de definições legais quanto à cessão ou arrendamento de terrenos e edificações. Considera-se, entre os entrevistados, que o primeiro fator de atração dos empresários para instalação ou participação no desenvolvimento do projeto sejam os incentivos ou benefícios fiscais, muito embora reconheçam que a aproximação e facilidade de acesso a centros de ensino e pesquisa são fatores importantes para manutenção desses empresários. 
- A seleção das experiências focalizadas na pesquisa de campo - dois fatores foram definitivos para a seleção das experiências a serem analisadas durante a pesquisa de campo: o primeiro as dificuldades decorrentes da pouca experiência em parques científicos ou tecnológicos, na concepção ora desenvolvida no país; a segunda, decorrente da primeira, foi identificar experiências intemacionais que se aproximassem dos critérios estabelecidos para a seleção, conforme visto na TAB. 4.1, e que concordassem em participar da pesquisa.

Com relação ao primeiro fator, embora o Panorama 2002 da ANPROTEC aponte a existência de 34 parques tecnológicos no país, apenas nove encontram-se em operação. Dentre esses nove, discute-se se alguns deles, na atualidade, constituem-se parques tecnológicos, na concepção aceita internacionalmente. Considerando-se a perspectiva de parques urbanos, aí este número, uma vez mais se restringe. Dessa forma, a pesquisa tentou focalizar experiências que contassem com estruturas próximas àquelas previstas para parques tecnológicos, na concepção urbana ou disseminado no meio urbano e que se enquadrassem nos critérios estabelecidos na TAB. 4.1.

Com relação ao segundo fator, buscou-se uma aproximação com algumas experiências internacionais, em modelos consagrados, tais como: o americano, o canadense, o português, o espanhol e o israelense, entre outros que foram acessados durante a pesquisa bibliográfica. Os contatos foram concretizados com o TAGUSPARQUE, de Portugal, o Parque Tecnológico de Andalucia, na Espanha e o Kiryat Weizmann Science Park, de Israel, que concordaram em participar integralmente na pesquisa e que apresentavam características culturais próximas (Portugal e Espanha) e experiências enriquecedoras em termos de políticas para o desenvolvimento regional baseadas no conhecimento (Israel com a necessidade de criar oportunidades para imigrantes russos e o advento do Departamento Cientista Chefe, conforme visto nos capítulos 5 e 6 ).

Tendo em vista que o objetivo primordial da pesquisa de campo foi o de obter conhecimentos sobre planejamento, implantação, gestão de parques tecnológicos, e sua contribuição para políticas públicas de desenvolvimento regional (e mesmo nacional), considera-se que as experiências analisadas foram suficientes para permitir o desenvolvimento do modelo proposto, muito embora elas não sejam exaustivas a respeito do tema. 


\section{CONCLUSÕES E RECOMENDAÇÕES}

"A criação de novos conhecimentos envolve tanto ideais quanto idéias." (Ikujiro Nonaka) ${ }^{1}$

Esta pesquisa teve por objeto o estudo do fenômeno dos parques tecnológicos, visando gerar um modelo conceitual atualizado para parques tecnológicos urbanos, particularizando, em seguida, para o caso da cidade de São Paulo, com foco nas regiões vizinhas à Cidade Universitária.

Foram apresentados os pressupostos para a pesquisa, partindo de uma concepção mais ampla, envolvendo os impactos da sociedade (economia) do conhecimento e dos mercados globalizados sobre as nações e as regiões, focalizando, especialmente, as grandes concentrações urbanas e seus problemas e carências intrínsecos, e chegando aos pressupostos específicos do estudo, relacionados à região da cidade de São Paulo, particularmente o entorno da Cidade Universitária, com sua alta densidade de instituições de ensino e pesquisa, com características desejáveis para a estruturação de parques tecnológicos, como instrumentos facilitadores e promotores de sinergia entre atores demandantes $e$ ofertantes de conhecimento e inovação tecnológica, criando um ambiente saudável de fertilização cruzada.

A pesquisa foi contextualizada e fundamentada à luz de seus pressupostos, estressando os temas a eles associados.

Analisando os aspectos relacionados aos processos de gestão competente do conhecimento nas nações, regiões e organizações, a argumentação apresentada aponta para a relevância e a necessidade do desenvolvimento de políticas e estratégias que estimulem ações coordenadas com vistas a:

- o incremento da competitividade das empresas pela gestão do conhecimento e pela criação de ambientes organizacionais indutores de inovação tecnológica, de forma sistemática;

\footnotetext{
1 NONAKA, I. A empresa criadora de conhecimento. In: HAVARD BUSINESS REVIEW (Ed.) Gestão do conhecimento. Tradução de Afonso Celso da Cunha Serra. Rio de Janeiro: Campus, 2000. p. 27-49. Título original: On knowledge management.
} 
- a disseminação do conhecimento decorrente de atividades acadêmicas, associada à visão de mercado do meio empresarial proporcionando a geração de projetos, idéias e produtos altamente competitivos, em termos globais;

- o estímulo à criação de novos postos de trabalho altamente qualificados e novos empreendedores em campos de tecnologia avançada e o desenvolvimento das comunidades, pelo aumento dos níveis de escolaridade, impulsionado pelas oportunidades geradas.

Com relação ao processo de globalização dos mercados e suas conseqüências, por um lado, os mercados globais consistem em oportunidade para as nações, as regiões e as organizações, no sentido do estabelecimento de novos e criativos arranjos, associações, alianças e redes, capazes de fortalecêlos para competir na nova lógica global, onde o conhecimento torna-se um importante ativo para a competitividade das organizações; por outro lado, no contraponto, o processo de globalização amplia a gama de problemas já enfrentados por nações e regiões menos desenvolvidas, indicando a premente necessidade de revisão das formas de gestão e condução de programas e políticas de instituições econômico-financeiras internacionais, de forma a promover uma participação mais significativa dos paises em desenvolvimento e estabelecer ações que possam disseminar os benefícios da globalização e amainar os seus malefícios.

No interesse desta pesquisa, considerou-se para a tipologia do termo "parque tecnológico" a definição da IASP como a formulação mais abrangente sem, no entanto, a ela se restringir, adicionando-se as novas tendências de formação de parques virtuais e a diversificação de fontes de conhecimento, em diferentes tipos de organizações, que permitem a geração de um fluxo multidirecionado de interação, com vistas à inovação e ao apoio ao desenvolvimento regional.

Foram identificados modelos regionais de parques tecnológicos, que caracterizam movimentos importantes e apresentam resultados sócio-econômicos relevantes para as regiões de influência, estando entre eles os modelos californiano, o britânico, o norte-europeu e o mediterrâneo. Também destacou-se como uma tendência a formação de associações e redes regionais e internacionais de parques tecnológicos, podendo-se comentar, especialmente, o 
desenvolvimento deste movimento, nos últimos anos, nos países asiáticos. Um aspecto importante relaciona-se a formas encontradas pelos parques tecnológicos para permitir a internacionalização de empresas a eles associadas, principalmente pela formação de alianças estratégicas, promovendo a expansão de suas atividades e permitindo a criação de subsidiárias e escritórios regionais dessas empresas em outros países.

Os resultados do movimento de parques tecnológicos foram vistos por meio dos seus indicadores em termos mundiais, conforme as pesquisas da IASP. Esses apontam para uma intensificação da criação de parques tecnológicos a partir da década de 90 e para uma tendência de crescimento do movimento no novo século. Os parques tecnológicos são geradores de empregos para a região em que atuam, principalmente para a mão-de-obra qualificada. Os números também indicam que $75 \%$ dos parques encontram-se em regiões urbanas, ou próximos a elas, sendo, porém, esta ocorrência relacionada, principalmente, a cidades pequenas, com até 500.000 habitantes; as experiências em cidades grandes (com mais de um milhão de habitantes) são ainda discretas. O fator proximidade com as instituições de pesquisa e ensino confirma-se como muito importante para os promotores dessas iniciativas, visto que a maior parte dos parques tecnológicos está muito próxima a campi universitários (76\%), sendo que $44 \%$ encontram-se localizados nos próprios campi; focalizando as relações entre as universidades e os parques, confirma-se o estabelecimento de um profícuo ambiente de fertilização cruzada visto que o número de ex-incubados e de "spinoff' nos parques vem crescendo nos últimos anos. Verifica-se que, nesse sentido, algumas universidades já preferem que seus escritórios de transferência e comercialização de tecnologia estejam situados nos parques tecnológicos (33\%), indicando uma busca pela aproximação com seus clientes potenciais.

Com relação ao movimento no Brasil, observou-se que, embora algumas iniciativas pioneiras tenham sido lançadas nas décadas de 80 e 90 , o movimento de parques tecnológicos no Brasil é tardio. Estudos apontam para um crescimento do movimento no Brasil na década de 90 , com tendência para uma expansão para os próximos anos, principalmente nas regiões sul e sudeste; grande parte do estímulo ao desenvolvimento desses modelos relaciona-se aos programas, incentivos e apoios políticos (nos níveis municipal, estadual e federal), demonstrando uma crescente conscientização da necessidade de políticas e 
estratégias inovadoras baseadas no conhecimento, para o desenvolvimento regional e nacional.

Realizando um balanço entre os aspectos positivos e negativos dos parques tecnológicos, muito se fala dos benefícios sócio-econômicos regionais advindos dos parques tecnológicos, estando entre eles: a conscientização das comunidades para a importância do conhecimento, da tecnologia e da inovação para o desenvolvimento das regiões e das nações; a consolidação de modelos e metodologias para criação (e sucesso) de empresas baseadas no conhecimento; o desenvolvimento da cultura de atuação em redes e a formação de alianças estratégicas; os impactos positivos nas regiões de influência. No entanto, no contraponto, encontram-se aspectos negativos que têm sido observados no desenvolvimento desses modelos, estando entre eles: o apoio público aos parques tecnológicos por vezes onera e inibi a atuação e gestão dessas iniciativas, trazendo prejuízos ao desenvolvimento de seus processos, principalmente com relação ao estabelecimento de um ambiente informal e de sinergia entre pesquisadores e empresários; em algumas experiências, embora os resultados econômicos sejam positivos, a vinculação prática com a universidade e instituições de pesquisas da região é inferior ao desejável e, muitas vezes, insuficiente; ainda não estão bem desenvolvidas formas para captação de organizações ou iniciativas de capital semente e de capital de risco no ambiente dos parques tecnológicos, ou mesmo, não existe uma séria preocupação com relação a este tema.

Foi apresentada, no texto, a caracterização das megacidades globais e seus desafios intrínsecos. Esta abordagem mostrou que essas cidades caracterizam-se não somente pela alta densidade populacional, mas sim pela considerável concentração de empresas do setor financeiro e de atividades de serviços que acumulam conhecimento e, em decorrência, são capazes de atrair investimentos de alto valor agregado. Essas atividades econômicas intensivas em conhecimento estão interconectadas em redes densas que, por sua vez, estimulam a criatividade e a inovação, permitem a recombinação e a mudança nas empresas e organizações com a necessária rapidez compatível com a velocidade de alteração dos requisitos dos mercados globais. No Brasil, existem duas metrópoles consideradas globais, a saber, Rio de Janeiro e São Paulo, que abrangem 60 municípios e concentram 17,3\% da população total do Brasil. Para 
participação no mercado global é mister a exploração e manutenção de características e fatores diferenciais frente aos impactos gerados pela "homogeinização" global e, portanto, essas metrópoles necessitam desenvolver estratégias e ações que levem à valorização de características locais, com um intenso processo de geração de valor, de criação de cultura e de conhecimento. Em busca de novas soluções, observam-se no Brasil, novas diretrizes de descentralização política e administrativa que têm levado a uma revisão dos processos de planejamento urbano e que buscam a efetiva participação da população, buscando soluções inovadoras para apoio ao desenvolvimento regional.

Foram também apresentadas as características das três regiões metropolitanas do Estado de São Paulo, ressaltando a existência de uma densa rede integrada entre elas, com funções produtivas complementares e, por arraste, englobando outras concentrações urbanas importantes no Estado, estando entre elas o Vale do Paraíba e Sorocaba. Especificamente com relação à Região Metropolitana de São Paulo, esta é considerada o maior pólo de riqueza nacional, concentrando uma série de serviços sofisticados e sedes de complexos industriais, comerciais e financeiros. A região constitui-se numa área de interesse para investimentos, como pode ser comprovado pelo acentuado número de empresas com capital de origem estrangeira instaladas na grande São Paulo, nos últimos anos. São Paulo, portanto, constitui-se em um dos nós da rede de cidades nas transações comerciais e financeiras globalizadas, principalmente no que diz respeito à América do Sul e à América Latina. Os efeitos da globalização são sentidos na cidade e caracterizados por intermédio dos movimentos urbanos, verificados nas últimas décadas. Esses movimentos configuram-se por novas tendências de ocupação de antigas áreas industriais de São Paulo, bem como pela instalação de empresas das áreas de logística e distribuição ao longo das principais vias de acesso ao município de São Paulo. Os urbanistas apontam como solução para o futuro de São Paulo, uma metrópole caracterizada pela descentralização, com o desenvolvimento de "centros" nos bairros que contenham uma mistura de atividades e que possam atender a interesses de diversos grupos, passando por uma necessária revisão das políticas de ocupação do solo e de zoneamento para a cidade. 
A mudança do perfil econômico do entorno da Cidade Universitária em São Paulo gera necessidades e oportunidades. Caracterizando a necessidade, esta micro-região passa por uma fase de redução da atividade econômica local, pela saída de várias indústrias e empresas tradicionais, compondo um cenário de áreas degradadas e economicamente deprimidas. Este movimento urbano evoca oportunidades estando entre elas ações de revitalização dessas áreas, de forma criativa e inovadora, já compatíveis com os requisitos da economia do conhecimento.

No contexto da região abordada encontram-se três subprefeituras do município de São Paulo, a saber: Butantã, Lapa e Pinheiros. Nessas subprefeituras, bem como nas outras regiões da cidade, está sendo orquestrado o movimento das "Operações Urbanas Consorciadas", coordenadas pelo Poder Público Municipal, que conta com ampla participação das comunidades, desde moradores até investidores privados, com o objetivo de, ao final do processo, alcançar em áreas específicas transformações urbanísticas estruturais, melhorias sociais, valorização ambiental e a ampliação e qualificação dos espaços públicos. Em decorrência, surge a oportunidade de implantação de iniciativas estruturantes como os parques tecnológicos urbanos, no caso, focalizando principalmente as regiões próximas à Cidade Universitária, cujos projetos devem contribuir para essas transformações e que se insiram na vida das regiões, baseados em conceitos que promovam a melhoria da qualidade de vida em suas áreas adjacentes, bem como estejam de acordo com os requisitos das operações urbanas.

Com relação à metodologia de pesquisa, foram aplicados os fundamentos do método científico hipotético-dedutivo e da pesquisa social ao planejamento e execução das fases deste estudo. Utilizando-se o instrumento de pesquisa desenvolvido bem como as entrevistas realizadas, foram analisadas sete experiências nacionais e três experiências internacionais, tendo sido possível conhecê-las em detalhe, sobretudo no que concerne às dimensões estabelecidas no referido instrumento, a saber: os aspectos relacionados à localização; o contexto sócio-econômico, político e cultural da região; a legislação de apoio; os aspectos estratégicos (missão, metas e concepção do modelo); aspectos relacionados ao gerenciamento; aspectos financeiros $e$ incentivos ao investimento; marketing e comunicação, incluindo aqui as ações de 
sensibilização; aspectos relacionados à formação e treinamento, privilegiando a gestão de negócios e o empreendedorismo; e os resultados obtidos e avaliação de impacto nas regiões de influência. Entre as conclusões da pesquisa de campo foram identificadas práticas de sucesso entre as experiências analisadas, ressaltando-se entre elas:

- A estrutura de legislação de apoio destacando-se: legislação referente à utilização e posse de terrenos, sistema de incentivos fiscais - casos das experiências de Parque de São Leopoldo (RS), Parque Tecnológico de Andalucía (Espanha) e Tagusparque (Portugal); a Lei de Pesquisa \& Desenvolvimento e apoio ao empreendedorismo por intermédio do Ministério da Indústria e Comércio (Departamento Cientista Chefe), no caso de Israel;

- As ações de estímulo às pesquisas e empresas que trabalham com produtos inovadores e que aproveitam as riquezas da região - a experiência do PADETEC (CE);

- A cooperação técnica internacional bem articulada que traz amplos benefícios aos projetos: o exemplo do Porto Alegre Tecnópole (com França e Espanha) e do Parque Tecnológico de Andalucía (Espanha) com as redes de cooperação internacional;

- O modelo do "Science Park Virtual" - serviços "on-line" para os associados - o exemplo do Tagusparque (Portugal) em associação com outros parques da Alemanha, Finlândia e Grécia;

- O Sistema de "Plataformas" do "Londrina Tecnópolis", decorrente de diagnóstico realizado na região alvo do projeto que identificou as potencialidades e gargalos por setor da economia local;

- As "Ações de Animação" do "Londrina Tecnópolis", que mantêm a comunidade informada e sensibilizada para as ações do projeto, angariando as simpatias e participação nas ações programadas;

- As ações de articulação para a recuperação de uma área degradada e economicamente deprimida - o exemplo do Porto Digital (PE); 
- A articulação de atores para utilização do potencial econômico, científico e tecnológico de uma região - o exemplo do Pólo de Alta Tecnologia de Campinas;

- A valorização da atividade acadêmica e da vocação tecnológica da região contando com 0 apoio institucional e político dos atores envolvidos - o exemplo do Parque Tecnológico de Rio de Janeiro.

Ainda com relação à pesquisa de campo são feitos os seguintes comentários:

- O Plano Diretor (ou estrutural) deve considerar o impacto ambiental na região de instalação do parque, principalmente sob os aspectos de proteção ambiental e melhoria ou recuperação de áreas degradadas;

- Os projetos arquitetônicos e a infra-estrutura de serviços devem conceituar uma visão holística, principalmente quando localizados no meio urbano, integrando as operaçōes do parque à vida da comunidade local, servindo também como uma opção de lazer e cultura, e de trabalho, auxiliando na formação de futuros empreendedores e apoiando as políticas urbanas implementadas pelo poder público; entre os elementos constitutivos dos parques tecnológicos, além dos serviços genéricos prestados à população que os freqüenta, devem existir, quando possivel, áreas residenciais e serviços de apoio a estas áreas (escolas, comércio), com o intuito de facilitar a vida dos trabalhadores e freqüentadores do parque, bem como proporcionar um movimento e animação salutar na região;

- Possíveis barreiras culturais existentes na região podem ser suplantadas por meio do desenvolvimento de fortes parcerias locais e de uma linguagem comum, contando para isso com eficientes projetos de comunicação e de ações comportamentais; a necessidade de investir na visibilidade do parque é considerada importante para o seu bom desenvolvimento;

- $80 \%$ dos entrevistados consideraram que a proximidade do parque a instituições de pesquisa e universidades traz benefícios para as empresas residentes; em decorrência, o desenvolvimento de 
instrumentos de parceria com essas instituições torna-se fator de importância para obtenção de resultados positivos;

- O arcabouço legal para apoio ao projeto foi considerado fator determinante para o sucesso do empreendimento; algumas das experiências analisadas enfrentam problemas por falta de definições legais quanto à cessão ou arrendamento de terrenos e edificações; considera-se que o primeiro fator de atração dos empresários para participação no projeto sejam os incentivos ou benefícios fiscais, muito embora esses reconheçam que a aproximação e facilidade de acesso a centros de ensino e pesquisa são fatores importantes para sua manutenção e sucesso;

- Nos casos analisados, os modelos, em sua maioria, iniciam-se a partir de uma incubadora de empresas, compondo-se, em sua estrutura, além da incubadora: condomínios empresariais, empresas ou organizações "âncoras", centros de pesquisa, empresas privadas de base tecnológica; a forma de organização varia entre empresas constituídas; entidades sem fins lucrativos, organização social ou organização civil de interesse público; ou mesmo fazendo parte de universidade, sendo administrado por meio de fundações de apoio;

- Os modelos de gestão são variados, sendo que nos casos nacionais é considerada importante a existência de um Conselho Superior com representantes de todos os parceiros e principais forças indutivas da comunidade, uma diretoria ou gerência executiva e um órgão fiscal, como estrutura básica; as experiências estrangeiras espelham uma realidade de estrutura de empresa;

- A atuação em redes temáticas é considerada importante para o desenvolvimento dos parques tecnológicos; o estabelecimento de cooperações internacionais traz ganhos positivos para 0 desenvolvimento das iniciativas;

- A preocupação em estimular as ações de treinamento em empreendedorismo e gestão de negócios na região de influência das experiências analisadas foi observada durante as entrevistas e nas informações veiculadas, embora a maior parte delas não atue 
diretamente na estruturação de cursos e treinamento nesta área; pode-se observar a importância que é dada a este tema visto que, entre as experiências, são identificadas associações com organizações de ensino e fomento para fins de treinamento e estímulo à cultura do empreendedorismo, acentuando-se o aspecto estratégico regional;

- As experiências analisadas, em sua maioria, não dispõem de um conjunto de indicadores de resultados ou de impactos regionais para mensurar a influência dos empreendimentos no desenvolvimento da região; no entanto, indicadores clássicos de resultados são aplicados pelas experiências estrangeiras; observa-se que a visibilidade não é medida, ou seja, não existem evidências relativas ao grau de importância dos empreendimentos para a vida da sociedade local, comentada pela própria sociedade; não estão estabelecidas práticas rotineiras de identificação e medição de impactos regionais.

Com base nos resultados da pesquisa de campo e nos estudos e realizados durante a pesquisa bibliográfica, foi desenvolvido um modelo conceitual para um parque tecnológico urbano, particularizando para o Parque Tecnológico de São Paulo, tendo sido, em seguida, realizada a discussão do modelo proposto, por tentativa de falseamento.

As principais conclusões gerais são abordadas a seguir, relacionandoas às questões da pesquisa.

Neste ponto, relembram-se as questões de pesquisa, a saber:

a) Como um modelo de parque tecnológico pode contribuir para proporcionar alternativas, baseadas no conhecimento e na inovação tecnológica, para 0 desenvolvimento das regiões urbanas, particularmente para a cidade de São Paulo?

b) Como um modelo de parque tecnológico pode aproveitar a alta densidade de instituições de ensino e pesquisa existente na região, de forma a contribuir com iniciativas estruturantes para a organização da sociedade local, frente aos desafios do novo paradigma do conhecimento?

c) Que características são recomendadas para um parque tecnológico urbano, como instrumento para estimular a sinergia entre os atores 
demandantes e ofertantes de conhecimento e inovação tecnológica?

Com relação à primeira questão, observa-se que no plano estratégico do modelo proposto (matriz lógica) está caracterizado o apoio ao desenvolvimento regional, dinamizando a atividade econômica local por meio da formação e crescimento de empresas baseadas no conhecimento, do incremento das atividades comerciais e de exportação de produtos e serviços com alto valor agregado e da geração de emprego e renda. Por outro lado, o modelo envolve empreendimentos imobiliários que podem oferecer a infra-estrutura necessária e que tornam compatível esta estrutura com o ambiente urbano e seus planos de desenvolvimento e diretor, bem como devem incorporar em seus projetos o apoio ao desenvolvimento sustentável e a recuperação de áreas degradadas ou economicamente deprimidas nas cidades.

O modelo propõe a integração do Parque Tecnológico com a cidade, atraindo a animação urbana e criando um ambiente de multifuncionalidade. Isto pode ser caracterizado pela proposta inovadora de disseminação das ações do parque na cidade, irradiando seus benefícios para as regiōes próximas ou áreas de influência. $O$ modelo dá um passo adiante na concepção de um parque tecnológico urbano, visto que prevê a criação de um núcleo gestor do parque, composto por algumas de suas estruturas organizacionais e de apoio, e a disseminação desse parque no meio urbano, pela ocupação de áreas disponiveis por aglomerações de empresas e serviços baseados no conhecimento ("clusters" de negócios tecnológicos), promovendo a atração de capital para a região, e criando um aspecto modular para o projeto, que pode auxiliar não somente à sua viabilização como também a experimentação dos processos de implantação, tanto das estruturas do núcleo gestor, como das estruturas disseminadas no meio urbano.

Com relação às questões (b) e (c), os parques tecnológicos são iniciativas que pressupõem uma base científica e tecnológica de apoio e que podem estabelecer ou otimizar, por meio de estruturas organizacionais formais ou informais, a formação de um ambiente de relações profícuas, imprescindivel para o sucesso de suas ações. O modelo de parque tecnológico ora proposto valoriza a proximidade entre atores, partilhando o princípio de que, apesar de as relações 
poderem ser facilitadas por modernos instrumentos e mecanismos de comunicação, a proximidade física é fator importante no processo de "fertilização cruzada". Esta valorização encontra-se caracterizada em dois níveis, nesta proposta (conforme representados nas FIG. 7.1 e 7.2): pelo do núcleo do parque tecnológico que engloba as atividades dos representantes do tripé governoempresa-academia, propondo estruturas que caracterizam essas relações; bem como em sua localização, no campus ou próximo a ele, facilitando o contato direto com os diversos departamentos e laboratórios, serviços tecnológicos e gerenciais disponiveis ("hardware" e "software"), criando um ambiente de estímulo à manutenção de relações férteis (sinergia, redes interpessoais) para o desenvolvimento dos novos negócios e para a disseminação do conhecimento. A atuação entre os representantes do tripé governo-empresa-academia se dá por meio de ações (ou organizações) que promovem e estimulam a interação entre os mesmos, a saber: a incubadora de empresas de base tecnológica, as estruturas para a gestão da interação academia-empresa (centros de pesquisa cooperativa, centro de serviços e formação empresarial, alianças estratégicas) e as ações de treinamento e formação técnica e em gestão empresarial. O Condomínio Empresarial e os "clusters" de negócios tecnológicos, integrantes do modelo, consistem em estruturas intimamente ligadas ao Núcleo do Parque Tecnológico e, portanto, sendo estimulados pela interação dos atores envolvidos no processo de inovação.

Como recomendações para futuros estudos, foram identificadas algumas lacunas que podem ser alvo de pesquisas mais aprofundadas, sobre este tema. Entre elas encontram-se:

- Com relação à conceituação de "parques tecnológicos" - no âmbito nacional existe uma certa confusão no que tange à conceituação de "parque tecnológico", o que pôde ser observado durante a pesquisa de campo; neste sentido poderia ser desenvolvida uma metodologia de "certificação" para projetos de parques tecnológicos, de forma a criar um padrão mínimo para essas iniciativas; as agências de fomento e os órgãos governamentais seriam beneficiários desse estudo, uma vez que novas políticas e programas estão sendo propostos em apoio a essas iniciativas, sendo necessário, portanto, aprimorar os sistemas de avaliação para novos projetos; 
- Alguns modelos internacionais de parques tecnológicos têm demonstrado sucesso em suas regiões de atuação, e existem ainda poucas informações ou estudos sobre eles; sugere-se, nesse sentido, que poderiam ser desenvolvidos estudos sobre as iniciativas e modelos relacionados aos movimentos asiáticos, estando inseridos neste contexto, os casos chinês, indiano e coreano; também poderiam ser estudadas, no âmbito da cooperação internacional, as alianças (estratégicas) que estão sendo formadas entre parques tecnológicos, situados em diferentes países e até mesmo em diferentès continentes, de forma a intensificar a internacionalização de suas empresas, como uma experiência interessante a ser seguida por parques tecnológicos nacionais;

- Foi observado durante o desenvolvimento da pesquisa que a falta de definição de indicadores de desempenho e sua correlação com as estratégias consiste em uma falha no planejamento de muitas experiências de parques tecnológicos; as fases de controle e de ações corretivas ao desenvolvimento dos projetos não são bem desenvolvidas, o que permitira criar uma base de informações de fundamental importância para os gestores, no que tange à revisão do planejamento e de estratégias para atingir os objetivos inicialmente propostos; identifica-se, portanto, a carência do desenvolvimento de uma metodologia para estabelecimento de indicadores de desempenho e sua correlação com as estratégias, para parques tecnológicos.

Tecendo alguns comentários finais, o modelo de Parque Tecnológico desenvolvido nesta pesquisa reúne os elementos estratégicos conceituais para parques tecnológicos, relacionados ao meio urbano, a saber:

- Objetivos e estratégias são definidos;

- Prevê a existência de uma estreita relação entre instituições governamentais (em diversos níveis), instituições acadêmicas e o meio empresarial, que atuem em direção ao sucesso do empreendimento e como forças mobilizadoras, mantendo um constante ambiente de animação em torno do projeto, incluindo aqui o incentivo à "animação urbana"; 
- Prevê a participação de instituições "âncoras" que possam garantir a manutenção de uma rede de conhecimentos (universidades, centros de pesquisa, instituições de gestão da interação, entre outros) que suportem o pleno funcionamento e objetivos do parque tecnológico;

- Propõe estruturas organizacionais operacionais que possam desenvolver as ações do parque tecnológico, em suas diversas formas de atuação.

Embora o movimento de parques tecnológicos esteja crescendo no país, as experiências inseridas no contexto das grandes metrópoles nacionais são ainda discretas. Os parques tecnológicos urbanos, na concepção que aqui foi apresentada por meio do modelo desenvolvido que prevê uma interação com a urbe, podem se constituir em subsidios para políticas públicas, baseadas no conhecimento, que contribuam para o desenvolvimento das metrópoles. Nesse sentido, ações devem ser conduzidas com vistas a captar o interesse dos formuladores de políticas e tomadores de decisão, de forma a incluir essas iniciativas no contexto do planejamento urbano. 
FICHA DE IDENTIFICAÇÃO

NOME DO EMPREENDIMENTO:

ENDEREÇO COMPLETO:

CEP: CIDADE: ESTADO:

IDENTIFICAÇÃO DOS MUNICÍPIOS VIZINHOS OU NA ÁREA DE INFLUÊNCIA DO EMPREENDIMENTO:

NOME DO DIRIGENTE:

TELEFONE/FAX: e-mail:

ENDEREÇO DA PÁGINA NA INTERNET:

IDENTIFICAÇÃO DO RESPONSÁVEL PELAS RESPOSTAS AO QUESTIONÁRIO:

TELEFONE: e-mail:

ÓRGÃOS PÚBLICOS APOIOADORES DO EMPREENDIMENTO (Comitê Executivo):

INSTITUIÇÕES PRIVADAS APOIADORAS DO EMPREENDIMENTO:

DATA DE FUNDAÇÃO (INICIO DAS ATIVIDADES): 


\section{O SISTEMA AMBIENTAL LOCAL:}

A.1 - O Plano Estrutural do Parque CT considera o impacto ambiental na região?
() Sim
( )Não Por que?

A.2 - A localização do Parque CT foi escolhida levando em conta fatores relacionados à qualidade ambiental da região?

( ) Sim. Selecione os aspectos considerados nesta escolha (pode ser mais de um):
( ) proteção;
( ) melhoria (recuperação);
( ) herança cultural;
( ) acesso público a espaços abertos;

( ) Não. Por que?

\section{ARQUITETURA, INFRA-ESTRUTURA, SERVIÇOS:}

\section{Acesso ao Parque:}

A.4 - Existem acessos diretos a rodovias/estradas principais(plano rodoviário) que possam ser percorridos de carro em até 20 minutos (em horário de pico: 7:00 às 10:00 horas e de 17:00 às 20:00 horas)?

( ) Sim. (por favor, identificar a rodovia ou rodovias)

( ) Não. Em quanto tempo é possível este acesso?

\section{A.5 - Acesso a aeroportos mais próximos:}

A.6 - Disponibilidade de transporte público:

Existe estação ferroviária/metrô (que possa ser alcançada a pé - máximo $1 \mathrm{~km}$ de distância)?

( ) $\operatorname{Sim}$

() Não. Qual é a distância?

Existe linha de ônibus (municipal, inter-municipal) com acesso ao Parque?

() $\mathrm{Sim}$

( ) Não. A que distância (metros, quilômetros) fica a parada da linha de ônibus?

Existe estação rodoviária (distância de ônibus ou carro que possa ser percorrida em até

20 minutos em horário de pico)?

() $\mathrm{Sim}$

( ) Não. A que distância (metros, quilômetros) fica a estação rodoviária (horas minutos)?

Existem outros tipos de transporte disponíveis (ônibus fretado, caminhonetes, etc...)?

( ) Sim. Especificar.

( ) Não

A.7 - Qual é o percentual de freqüentadores/trabalhadores do Parque que usam automóvel particular para ir ao trabalho? Não se aplica.

( ) de 0 a $20 \%$

( ) de 21 a $40 \%$

( ) de 41 a $60 \%$

( ) acima de $60 \%$

A.8 - Na sua opinião, é necessário que o Parque CT esteja próximo à Universidade ou a Instituições de Pesquisa? Se positivo, discrimine os benefícios desta proximidade. Não se aplica a esta experiência. 


\section{INFRA-ESTRUTURA:}

A.9 - Qual era o principal uso anterior do local do Parque CT? (Não se aplica para esta experiência). O Projeto Londrina Tecnópolis está instalado, no momento, em uma sala na sede da ADETEC.

( ) terrenos/edificações sem uso, de propriedade do município (ou do estado, ou federal), ou de empresas públicas, cedidos ao Parque CT;

( ) terrenos/edificações sem uso, da Universidade ou de Instituições de Pesquisa públicas, cedidos ao Parque CT;

( ) terrenos agrícolas não explorados economicamente ( do poder público ), cedidos ao Parque CT;

( ) terrenos agrícolas privados cedidos ou desapropriados, para instalação do Parque CT;

( ) terrenos/edificações de empresas privadas, sem uso, cedidos para o Parque CT;

( ) terrenos/edificações adquiridos/construídos especificamente para o Parque CT.

A.10 - Área total do Parque CT: .......................(m² $\mathrm{m}^{2}$;

A.11 - Área construída do Parque CT: ..............( $\left.\mathrm{m}^{2}\right)$;

A.12 - Área para estacionamento: .....................( $\left(\mathrm{m}^{2}\right)$;

A.13 - Área verde/projeto paisagistico: ..............( $\left(\mathrm{m}^{2}\right)$;

A. 14 - Existe um Plano de Urbanização para o Parque CT? Se positivo, quais os itens que são considerados neste Plano?

( ) planejamento físico - uso dos espaços;

( ) localização - padrão de ruas;

( ) plano de circulação (tráfego);

( ) infra-estrutura de fornecimento de água, capacidade de esgotos, fornecimento de energia elétrica;

( ) redes de comunicação (telefonia, redes de fibra ótica, etc...);

( ) outros itens - especifique

A.15 - Existe uma política clara quanto à negociação de terrenos (arrendamento, venda, etc...)? Se positivo, descreva esta política.

A.16 - Existem ações programadas de controle arquitetônico e paisagístico? Se positivo, discrimine estas ações.

A.17 - Existem centros de serviços (comércio varejista, bancos, etc...) para atender aos integrantes do Parque CT? De que tipo?

PARTE B: CONTEXTO SÓCIO-ECONÔMICO, POLÍTICO E CULTURAL DA REGIÃO

INFORMAÇÕES DEMOGRÁFICAS DA REGIÃO:

B.1 - O Parque CT está localizado em:

( ) na região metropolitana de pela Lei de número de . Esta região metropolitana foi criada municípios e ocupando uma superfície de

( ) próximo ou na zona de influência da região metropolitana de Esta região metropolitana foi criada pela Lei de número de $1-1 \frac{1}{\mathrm{~km}^{2}}$, abrangendo municípios e ocupando uma superfície de

A região considerada nesta experiência, apesar de polarizar alguns municípios menores, não se constitui em uma região metropolitana.

B.2 - Na região onde está localizado o Parque CT vivem aproximadamente de habitantes. 
INFORMAÇÕES ECONÔMICAS DA REGIÃO:

B.3 - Assinale quais são os setores de atividade econômica da região onde está localizado o Parque CT (preferencialmente as informações devem estar relacionadas à região metropolitana):

() agricultura

( ) extração mineral

() indústria de transformação ( produtos minerais não metálicos, indústria metalúrgica, indústria mecânica, de material elétrico, eletrônico e de comunicação, indústria de material de transporte, indústria de madeira e mobiliário, indústria de papel, papelão, editoração e gráfica, indústria de borracha, fumo e couro, indústria química, indústria têxtil, vestuário, indústria de calçados, indústria de produtos alimentícios e bebidas, serviços industriais de utilidade pública)

( ) indústria da construção civil

( ) comércio (varejista, atacadista)

() serviços (ensino, médico, odontológico e veterinário, de administração técnica e profissional; de instituições financeiras, serviços de transportes e comunicações, serviços de alojamento e alimentação, serviços de manutenção e reparos)

( ) administração pública

( ) outros. Especifique Deve-se destacar a oferta considerável de serviços nas áreas de ensino e médico-hospitalar em Londrina.

B.4 - Discrimine as principais atividades econômicas que são influenciadas pelas ações/tecnologias/serviços do Parque CT.

B.5 - Discrimine as principais atividades econômicas de exportação da região.

ESTRATÉGIAS DE DESENVOLVIMENTO REGIONAL:

( Por favor, em todos os casos, indique leis, portarias, contratos, etc...)

B.6 - Discrimine as políticas de desenvolvimento regional, conduzidas pelo município, adotadas em apoio às atividades do Parque CT (por exemplo: redução de impostos sobre produtos com alto conteúdo tecnológico produzidos no Parque; políticas de criação de demanda por tecnologia pelo estabelecimento, na região, de infra-estrutura tecnológica básica; outras políticas para estimular mecanismos de difusão.)

B.7 - Discrimine as políticas de desenvolvimento regional, conduzidas pelo estado, adotadas em apoio às atividades do Parque CT.

B.8 - Discrimine as políticas de desenvolvimento regional, conduzidas com o apoio do governo federal, adotadas em apoio às atividades do Parque CT.

B.9 - Discrimine as políticas de desenvolvimento regional em apoio às atividades do Parque CT, que tem forte participação da iniciativa privada local.

POLÍTICAS PARA SUPLANTAR BARREIRAS CULTURAIS NA REGIÃO:

B.10 - Identifique que tipos de ações são desenvolvidas para suplantar barreiras culturais locais:

( ) desenvolvimento de parcerias locais. Especifique:

( ) ações no mercado local de trabalho. Especifique:

( ) desenvolvimento de uma linguagem comum, ações comportamentais, etc... Especifique

( ) outras ações. Especifique 
B.11 - Identifique os benefícios para as comunidades vizinhas com o advento do Parque de CT:

( ) valorização de imóveis;

( ) incremento da movimentação do comércio local ;

( ) reversão de benefícios pela arrecadação de impostos, serviços de empresas públicas;

( ) melhorias nas condições de vida da população local;

discrimine os três benefícios mais significativos para as comunidades vizinhas, desde o início das atividades do Parque CT

\section{AÇÕES DOS ÓRGÃOS DE DESENVOLVIMENTO REGIONAL:}

B.12 - Quais são os órgãos de desenvolvimento regional envolvidos com o Parque CT?

B.13 - Que tipo de ação desenvolvida por esses órgãos resultou em benefícios claros para o desenvolvimento do Parque CT?

\section{PARTE C: LEGISLAÇÃOO DE APOIO}

C.1 - Foi proposta e implantada uma legislação específica criando áreas para parques científicos/tecnológicos, sendo discriminadas claramente as formas de uso adequado dos espaços e tipos de atividades permitidas (usos industriais, usos para centros de serviços, etc...)? Caso positivo, por favor, informe: Lei número de _ _ _ _ _ , (municipal, estadual) e os principais artigos da Lei

C.2 - Indique leis, portarias que caracterizem apoio às ações do Parque CT (incentivos fiscais entre outras possibilidades de apoio) bem como visem acelerar o desenvolvimento regional.

C.3 - O Parque CT tem um regulamento interno ou outro documento que registre os seus aspectos normativos?

( ) Sim ( ) Não. Por que?

\section{PARTE D: MISSÃO, METAS, MODELO E ESTRUTURA DO PARQUE CT}

D.1 - Principais dados históricos da concepção/implantação do Parque CT.

(Discrimine 4 fatos históricos)

(a)

(b)

(c)

(d)

D.2 - Visão e Missão: 
D.3 - Objetivos estratégicos e Metas :

$\vec{D}$

Metas:

D

Entre os objetivos estratégicos do empreendimento, assinale com um " $X$ " na opção correta com relação aos aspectos que são considerados:

\begin{tabular}{|l|c|l|l|}
\hline \multicolumn{1}{|c|}{ Aspectos } & $\begin{array}{c}\text { Muito } \\
\text { importante }\end{array}$ & Importante & $\begin{array}{c}\text { Não } \\
\text { considerado }\end{array}$ \\
\hline $\begin{array}{l}\text { Ações de apoio ao desenvolvimento } \\
\text { regional }\end{array}$ & & & \\
\hline Ações de estímulo às exportações & & & \\
\hline $\begin{array}{l}\text { Ações de apoio à diversificação das } \\
\text { atividades econômicas da região }\end{array}$ & & & \\
\hline $\begin{array}{l}\text { Ações de apoio ao desenvolvimento } \\
\text { tecnológico na região }\end{array}$ & & & \\
\hline Ações de apoio à geração de empregos & & & \\
\hline $\begin{array}{l}\text { Ações de apoio à disseminação do } \\
\text { empreendedorismo }\end{array}$ & & & \\
\hline $\begin{array}{l}\text { Ações de busca da auto-sustentação do } \\
\text { empreendimento }\end{array}$ & & & \\
\hline
\end{tabular}

D.4 - Características do modelo adotado: (descreva as cinco (05) principais características; identifique algum modelo nacional ou internacional com características semelhantes)

\section{PARTE E: GERENCIAMENTO DO PARQUE}

MODELO DE GESTÃO

E.1 - Descreva a estrutura organizacional do Parque CT: (se possivel, insira figura do organograma oficial do Parque)

E.2 - Existe um Conselho Diretor, Consultivo ou Deliberativo. Qual a sua composição?

E.3 - Qual é a principal instituição gestora do Parque ( ou principais instituições gestoras)?

E.4 - Quais são as organizações "âncoras" ?

E.5 - Como é definida a equipe do Parque e qual é o processo de contratação de pessoal? 
E.6 - Como são gerenciados/executados os serviços de assistência técnica e gerencial às empresas residentes e/ou associadas? Utiliza 0 apoio de consultores externos? De que forma?

\section{PROCESSOS DE SELEÇÃO}

E.7 - Descreva a metodologia para o processo de seleção de empresas.

E.8 - Descreva a metodologia para o acompanhamento das empresas (processo de avaliação/ indicadores de desempenho adotados).

PROGRAMAS DE PARCERIA E PARTICIPAÇÃO EM REDES

E.9 - O Parque CT está associado a entidades/associações de Parques nacionais e internacionais? Quais?

E.10 - O Parque CT está associado a outras entidades/associações? Quais?

E.11 - Existem ações claras de estímulo à troca de informações/experiências com outros empreendimentos assemelhados? Seria possivel citar duas experiências bem sucedidas neste sentido?

E.12 - O Parque CT participa de redes de informação, de base tecnológica, regionais, nacionais ou internacionais? Por favor, discrimine as redes nas quais participa.

E.13 - Os projetos de cooperação desenvolvidos no âmbito do Parque CT são formalizados?

( ) Sim. Existe um modelo contratual estabelecido para este fim.

( ) Não. Não há formalização dos compromissos.

( ) Sim. Porém não há um modelo contratual padronizado para este fim.

\section{PROPRIEDADE INTELECTUAL}

E.14 - Os aspectos relativos à propriedade intelectual/industrial são considerados no regulamento do empreendimento?

( ) Sim.

( ) Não. Por que?

E.15 - Existe uma assessoria/consultoria específica contratada (ou mesmo no quadro de pessoal do empreendimento) para tratar desse assunto?

( ) Sim. Por favor, especifique de que forma é contratado este serviço.

( ) Não.

E.16 - Por favor, assinale as opções que correspondem à realidade da atuação do empreendimento com relação a este tema:

() Este tema não é uma preocupação importante para o empreendimento.

( ) Este tema não é uma preocupação importante, no momento, porém há fortes intenções de estabelecer uma política de atuação, bem como um regulamento com relação à propriedade intelectual/industrial. 
( ) Este assunto é deixado a cargo de cada uma das empresas incubadas ou participantes do empreendimento, não havendo qualquer atuação da gestão do empreendimento com relação a este assunto.

( ) Este assunto é tratado pelas instituições de pesquisa/universidade associadas ao empreendimento, por meio de seus escritórios de patentes ou da forma como este assunto é tratado naquelas instituições.

\section{PARTE F: ASPECTOS FINANCEIROS, INCENTIVOS AO INVESTIMENTO}

\section{ORÇAMENTO}

\section{F.1 - Qual é o custo operacional anual do Parque CT?}

( ) até $\mathrm{R} \$ 100.000,00$

( ) de $R \$ 101.000,00$ a $R \$ 500.000,00$

( ) de $R \$ 501.000,00$ a $R \$ 1.000 .000,00$

( ) acima de $R \$ 1.000 .000,00$

\section{F.2 - Distribuição percentual média do custo operacional do Parque CT:}

( ) \% Recursos provenientes de entidades privadas (por favor, discrimine as entidades)

( ) \% Recursos provenientes de pagamentos feitos pelas empresas do Parque.

( ) \% Recursos provenientes de entidades públicas, orçamentos de governo (municipal, estadual, federal), empresas de economia mista (por favor, discrimine as entidades)

( ) \% Recursos provenientes de Instituições e agências de fomento e apoio, públicas ou privadas (por favor, discrimine as entidades).

( ) \% Programas internacionais, agências internacionais e outras fontes internacionais (por favor, discrimine as fontes)

( ) \% Outras fontes (por favor, discriminar)

F.3 - Total de investimentos das entidades parceiras no empreendimento, desde sua concepção (incluindo prefeituras, governos, fundações, universidades, bancos de desenvolvimento, agências de fomento privadas e públicas, etc...):

$\mathrm{R} \$$ $\mathrm{R} \$$ da entidade parceira da entidade parceira

( inclua outros itens se necessário)

\section{ESTRATÉGICAS DE AUTO-SUSTENTAÇÃO}

\section{F.4 - Existem expectativas de busca da auto-sustentação do Parque de CT?}

( ) Sim, com as seguintes estratégias: anos. 


\section{F.5 - Quais os exemplos nacionais e/ou internacionais estão sendo considerados nesta busca pela auto-sustentação?}

\section{F.6 - Assinale a opção correta dentro da visão estratégica para o empreendimento.}

( ) O empreendimento será inteiramente auto-suficiente após sua plena implantação;

( ) O empreendimento será $50 \%$ auto-suficiente após sua plena implantação;

( ) O empreendimento continuará a receber recursos significativos (acima de $50 \%$ do seu custeio anual) para arcar com o seu custeio provenientes de órgãos públicos (por favor, discriminar).

( ) O empreendimento continuará a receber recursos significativos (acima de $50 \%$ do seu custeio anual) para arcar com o seu custeio provenientes de órgãos públicos e entidades privadas (por favor, discriminar).

\section{CAPITAL INICIAL E CAPITAL DE RISCO}

F.7 - O Parque de CT estimula a participação de fundos de capital de risco junto às empresas ligadas ao empreendimento?

( ) Sim

( ) Não. Por que?

F.8 - Como se dá a aproximação destes fundos ou a captação pelo seu interesse?

( ) A partir de eventos especificamente organizados para este fim, pelo Parque CT, com o apoio das entidades parceiras.

( ) A partir de aproximação independente realizada junto às próprias empresas, não havendo acompanhamento da gerência do Parque ou qualquer participação no processo.

( ) A partir de aproximação organizada pelo Parque CT, previamente planejada, de forma regular, observando-se os interesses das empresas e os objetivos estratégicos do empreendimento.

( ) A partir da promoção da participação das empresas em eventos promovidos por programas de Venture Capital de instituições governamentais ou privadas (como rodadas de negócios, Programa INOVAR/FINEP, etc..)

F.9 - Há uma preocupação do Parque CT em manter/disponibilizar informações atualizadas sobre oportunidades relativas à captação de capital de risco/ capital inicial para seus associados?

( ) Sim, isto é feito de forma organizada e regular, utilizando-se como meios de divulgação: (discrimine a forma de divulgação)

( ) Não, as oportunidades são tratadas à medida que aparecem.

PARTE G: MARKETING E COMUNICAÇÃO

\section{AÇÕES DE SENSIBILIZAÇÃO}

G.1 - São desenvolvidas ações organizadas de comunicação direta junto a lideranças e formadores de opinião da região? (assinale a opção correta)

( ) Sim. Utilizando-se os seguintes instrumentos: (por favor, discrimine os instrumentos de comunicação utilizados para ações de sensibilização tais como jornais, boletins, informes, reuniões, seminários, festas, etc...) 
( ) Não. As ações existentes não são organizadas, porém há uma preocupação em desenvolver contatos com lideranças e formadores de opinião da região.

( ) Não. Não são desenvolvidas ações junto a lideranças e formadores de opinião na região.

\section{G.2 - São desenvolvidas parcerias com organizações "âncoras" do Parque CT ou participante do empreendimento com vistas a estabelecer uma política de comunicação e marketing para a região?}

( ) Sim. Existe uma política de comunicação e marketing para a região com o apoio e forte atuação das empresas "âncoras" e do setor empresarial da área;

( ) Sim. Existe uma política de comunicação e marketing para a região com o apoio e forte atuação do setor privado e do setor público;

( ) Não. Não foi possível desenvolver, até o momento, uma parceria que propicie o desenvolvimento de uma política de comunicação e marketing para a região, com o setor privado, porém estão sendo despendidos esforços neste sentido.

( ) Não. Não foi estabelecida uma política de comunicação e marketing para a região em apoio ao empreendimento.

\section{ASSESSORIA DE MARKETING PARA AS EMPRESAS}

\section{G.3 - Existe um calendário anual de eventos que apoie as atividades das empresas participantes do empreendimento? (assinale a opção correta)}

( ) Sim, existe um calendário anual de eventos regionais que apoiam as atividades das empresas.

( ) Sim, existe um calendário anual de eventos programados, organizados pelo Parque CT e também externos, desenvolvidos por outras entidades, em outras regiões, que apoiam as atividades das empresas.

( ) Não existe um calendário anual de eventos programados, porém a equipe do Parque CT se preocupa em levantar eventos de interesse para as empresas e viabilizar sua participação nos mesmos.

( ) Não existe um calendário anual de eventos programados. A participação das empresas em eventos é responsabilidade e decisão das próprias empresas.

\section{G.4 - Como é realizada a assessoria em marketing para as empresas? (assinale a opção correta)}

( ) Por meio de uma empresa contratada pelo empreendimento para este fim, havendo limitações de serviços de acordo com o Plano de Marketing estabelecido pelo Parque CT.

( ) Por meio de uma empresa contratada pelo empreendimento para este fim, porém havendo um contrato de risco, ou seja, os serviços são pagos pelas próprias empresas, de acordo com suas necessidades específicas.

( ) O Parque CT disponibiliza, nos seus quadros, especialistas para apoiar as empresas nestes assuntos, porém os serviços adicionais (tais como gráficas, desenhos, etc..) são contratados pelas próprias empresas.

( ) O Parque CT não disponibiliza nem intermedia serviços de assessoria em marketing para as empresas.

( ) Outras formas de atuação. (especifique) 


\section{H.1 - O Parque CT organiza ações de treinamento em empreendedorismo?}

( ) Sim. Com o apoio de entidades de ensino, associações comerciais e/ou industriais, agências governamentais, da iniciativa privada (por favor, especifique as entidades que apoiam esta iniciativa). As ações de treinamento são voltadas para a comunidade do Parque bem como para a região.

( ) Sim. Com recursos próprios e contratação de consultores para este fim. As ações de treinamento são voltadas para a comunidade do Parque bem como para a região.

( ) Não. Porém estimula seus associados a participarem de eventos e cursos ministrados por outras entidades, facilitando este processo.

( )Não. Porém estimula seus associados a participarem de eventos e cursos ministrados por outras entidades sem, no entanto interferir ou facilitar este processo.

H.2 - O Parque CT procura realizar convênios ou acordos com instituições de ensino técnico para facilitar ações de treinamento entre os seus associados e para a comunidade do Parque CT?

( ) Sim. São efetuados convênios, contratos e/ou acordos com entidades governamentais ou da iniciativa privada para fins de treinamento e formação técnica, de acordo com as necessidades e estratégias estabelecidas pelo Parque CT e seus associados.(Discrimine os principais acordos realizados neste sentido, e o tipo de curso/evento de treinamento que é ministrado)

( ) Não. As iniciativas com relação a este assunto são realizadas pelos próprios associados, de acordo com seus interesses específicos.

( ) Não. As iniciativas com relação a este assunto são esporádicas,

H.3 - O Parque CT está associado a alguma organização ou rede para fins de treinamento?

( ) Sim. Com as organizações/redes:

( ) Não

H.4 - O Parque CT proporciona cursos especificamente para a elaboração de Planos de Negócios para seus associados?

( ) Sim. Com recursos próprios e com a contratação de consultores.

( ) Sim. Com recursos próprios e com pessoal próprio.

( ) Não. Porém os associados são estimulados a buscarem este treinamento em agências e outras organizações, por conta própria.

PARTE I: RESULTADOS OBTIDOS; AVALIAÇÃO DO IMPACTO NA REGIÃO

I.1 - Quais são as três principais transformações sobre a organização/ocupação da região provocadas pela instalação do Parque CT?

I.2 - Aponte os principais resultados obtidos desde a implantação do projeto:

( ano base para informações atualizadas - 2000)

( tratando-se de projeto ainda não implantado por favor, discrimine os resultados

esperados, previstos para após a implantação - última coluna) 


\begin{tabular}{|l|l|l|l|}
\hline Principais Resultados & $\begin{array}{c}\text { Desde a } \\
\text { implantação } \\
\text { do projeto }\end{array}$ & No ano 2000 & $\begin{array}{c}\text { Previsto a } \\
\text { partir da } \\
\text { implantação } \\
\text { do projeto }\end{array}$ \\
\hline $\begin{array}{l}\text { número de empresas de base } \\
\text { tecnológica criadas }\end{array}$ & & & \\
\hline número de empregos diretos gerados & & & \\
\hline número de empregos indiretos gerados & & & \\
\hline $\begin{array}{l}\text { faturamento total gerado pelas } \\
\text { empresas (R\$/ano) }\end{array}$ & & & \\
\hline $\begin{array}{l}\text { faturamento gerado pelo Parque com } \\
\text { prestação de serviços diversos } \\
\text { (R\$/ano) }\end{array}$ & & & \\
\hline $\begin{array}{l}\text { número de patentes de novos produtos } \\
\text { geradas pelas empresas associadas ao } \\
\text { Parque }\end{array}$ & & \\
\hline $\begin{array}{l}\text { número de sistemas produtivos locais } \\
\text { estruturados por influência do Parque } \\
\text { (cooperativas, distritos industriais, } \\
\text { "clusters", redes, incubadoras, etc...) }\end{array}$ & & \\
\hline $\begin{array}{l}\text { número de projetos cooperativos } \\
\text { desenvolvidos no âmbito do Parque } \\
\text { (entre as empresas e organizações } \\
\text { externas, incluindo instituições de } \\
\text { pesquisa e ensino) }\end{array}$ & & & \\
\hline $\begin{array}{l}\text { número de empresas de médio e } \\
\text { grande porte atraídas para a região }\end{array}$ & & & \\
\hline $\begin{array}{l}\text { volume de investimentos atraídos para } \\
\text { a região (em R\$ e em US\$) }\end{array}$ & & & \\
\hline $\begin{array}{l}\text { número de eventos realizados para a } \\
\text { sensibilização da comunidade local } \\
\text { para o projeto (incluindo o meio político } \\
\text { e o empresarial) (feiras, exposições, } \\
\text { seminários, reuniōes, visitas, etc...) }\end{array}$ & & & \\
\hline $\begin{array}{l}\text { número de participantes nos eventos } \\
\text { realizados para a sensibilização }\end{array}$ & & & \\
\hline $\begin{array}{l}\text { número de rodadas de } \\
\text { negócios/eventos promocionais em } \\
\text { apoio às empresas }\end{array}$ & & & \\
\hline $\begin{array}{l}\text { volume de negócios realizados a partir } \\
\text { desses eventos (R\$) }\end{array}$ & & \\
\hline $\begin{array}{l}\text { número de eventos de treinamento em } \\
\text { empreendedorismo realizados }\end{array}$ & & \\
\hline $\begin{array}{l}\text { número de participantes treinados } \\
\text { nesses eventos }\end{array}$ & & \\
\hline $\begin{array}{l}\text { número de eventos de treinamento em } \\
\text { cursos técnicos ou de qualidade, } \\
\text { incluindo informática }\end{array}$ & & \\
\hline $\begin{array}{l}\text { número de participantes treinados } \\
\text { nesses eventos }\end{array}$ & & \\
\hline $\begin{array}{l}\text { outros resultados considerados } \\
\text { relevantes para o projeto (discrimine) }\end{array}$ & & & \\
\hline
\end{tabular}




\section{Logical Framework do Projeto/Empreendimento}

Nome do Empreendimento:

\begin{tabular}{|l|l|}
\hline Objetivo Superior & \\
\hline $\begin{array}{l}\text { Objetivos imediatos ou do } \\
\text { projeto }\end{array}$ & \\
\hline $\begin{array}{l}\text { Produtos ou resultados } \\
\text { esperados }\end{array}$ & \\
\hline Efeitos/impactos & \\
\hline Pressupostos relevantes & \\
para o êxito do projeto & \\
\hline Melhores práticas & \\
\hline identificadas & \\
\hline
\end{tabular}




\section{REFERÊNCIAS BIBLIOGRÁFICAS}

1 ALBAGLI, S. Globalização e Espacialidade: o Novo Papel do Local.In: IBICT/MCT (Ed.). Globalização \& Inovação Localizada: Experiências de Sistemas Locais no MERCOSUL, Brasília: IBICT, 1999.

2 ANPROTEC; SEBRAE. Glossário dinâmico de termos na área de tecnópolis, parques tecnológicos e incubadoras de empresas. Brasília: ANPROTEC, 2002. Disponível em <http://www.anprotec.org.br/glossario>. Acesso em: 22 dez. 2002.

3 ANPROTEC. Panorama 2002. Brasília: ANPROTEC, 2002.

4 BENKO, G. Géographie des technopôles. Paris, França: Masson, 1991 apud TAVARES, H.M. Pólos Tecnológicos, Meio Urbano e Planejamento do Território In: VIII SEMINÁRIO DE PARQUES TECNOLÓGICOS E INCUBADORAS DE EMPRESAS. 1998, Belo Horizonte. Anais... Belo Horizonte: ANPROTEC, 1998.

5 BOLTON, W. The university handbook on enterprise development. Paris: Columbus Handbooks, 1997.

6 BORTAGARAY, I.; TIFFIN, S. Innovation clusters in Latin America. In: $4^{\text {th }}$ INTERNATIONAL CONFERENCE ON TECHNOLOGY POLICY AND INNOVATION. August 28-31, 2000, Curitiba, Paraná. Proceedings... Curitiba: CITS/PUCPR/IBQP-PR/TECPAR/PARANA CLASSE MUNDIAL, 2000. CDROM.

7 CASSIOLATO, J.E. A relação universidade e instituições de pesquisa com o setor industrial: uma abordagem a partir do processo inovativo e lições da experiência internacional. Brasilia: ABIPTI/SEBRAE/CNPq, 1996.

8 CASSIOLATO, J. E., LASTRES, H.M.M. Inovação, Globalização e as novas Políticas de Desenvolvimento Industrial e Tecnológico.In: IBICT/MCT (Ed.). Globalização \& Inovação Localizada: Experiências de Sistemas Locais no MERCOSUL, Brasilia: IBICT, 1999.

9 CASTELLS, M. A questão urbana. Tradução de Arlene Caetano. Edição revisada 1. Reimpressão. São Paulo: Paz e Terra, 1983. Título original: La question urbaine.

10 CASTELLS, M. The rise of the network society. Oxford: Blackwell Publishers, p. 92, 1998. 
11 CASTELLS, M. Fim de milênio. Tradução de Klauss Brandini Gerhardt e Roneide Venâncio Majer, 2.ed. São Paulo: Paz e Terra, 1999. Título original: End of millennium.

12 CASTELLS, M., HALL, P. Technopolis del mundo: la formación de los complejos industriales del siglo XXI. Madri, Espanha: Alianza Editorial, 1994 apud TAVARES, H.M. Pólos Tecnológicos, Meio Urbano e Planejamento do Território In: VIII SEMINÁRIO DE PARQUES TECNOLÓGICOS E INCUBADORAS DE EMPRESAS. 1998, Belo Horizonte. Anais... Belo Horizonte, M.G.: ANPROTEC, 1998.

13 DRUCKER, P. Sociedade pós-capitalista. Tradução de Nivaldo Montingelli Jr. São Paulo: Pioneira; São Paulo: Publifolha, 1999. Título original: Postcapitalist society.

14 EMPLASA. Empresa Metropolitana de Planejamento da Grande São Paulo, 2003. Apresenta dados sobre a região metropolitana de São Paulo. Disponivel em: http://www.emplasa.sp.gov.br/metropoles/. Acesso em 18 mar. 2003.

15 ERNO-KJOLHEDE, E.; HUSTED, K.; MONSTED, M.; WENNEBERG, S.B. Managing university research in the triple helix. Science and Public Policy, v. 28, n. 1, p. 49-55, 2001.

16 ETZKOWITZ, H. Incubation of incubators: innovation as a triple helix of university-industry-government networks. Science and Public Policy, v. 29, n.2, p. 115-128, 2002.

17 FINEP/CNI A indústria e a questão tecnológica. Brasília: FINEP, 2002. Disponível em: <www.cni.org.br/f-ps-sondind.htm>. Acesso em: 10 fev. 2003. 18 FOLHA DE SÃO PAULO Serviços invadem área industrial de SP. Folha de São Paulo, São Paulo, Imóveis 1, p. 1, 29 jul. 2001.

19 FORMICA, P. Atores inovadores do desenvolvimento econômico: empresas "acadêmicas" e universidades "empreendedoras" em ação nos ecossistemas territoriais e empresariais de inovação. In: GUEDES, M.; FORMICA, P. (Ed.) A economia dos parques tecnológicos. Rio de Janeiro: ANPROTEC, 1997.

20 GESVENTURE Glossário de termos sobre capital de risco. Lisboa, Portugal: GESBANHA, 2003. Disponivel em: <http://www.gesventure.pt/gloss.htm>. Acesso em: 03 fev. 2003.

21 GIL, A.C. Métodos e técnicas de pesquisa social. 5.ed. São Paulo: Editora Atlas S.A., 1999. 
22 GIUNTA, F.J. The emerging paradigm of new urbanism in science park development. In: V WORLD CONFERENCE ON SCIENCE PARKS. October 29-31, 1996, Rio de Janeiro. Proceedings... Rio de Janeiro:

AURRP/IASP/ANPROTEC, 1996.

23 HAMEL, G. Bringing Silicon Valley Inside. Harvard Business Review, p. 71 84, September-October 1999.

24 HAUSER, G. Parques tecnológicos e meio urbano. In: PALADINO, G.; MEDEIROS, L.A. (Org.) Parques tecnológicos e meio urbano: artigos e debates. Brasília, D.F.: ANPROTEC, p. 85-99, 1997.

25 IDEA. Catálogo general del Parque Tecnológico de Andalucía. Málaga, Espanha. Disponivel em: http://www.pta.es/. Acesso em: 23 jan.2003.

26 IPEA/IBGE/UNICAMP/SEADE Caracterização e tendências da rede urbana do Brasil. Campinas: IE-UNICAMP, 1999. Disponível em:

http://www.siriopreto.org.br/planejamento/Forum\%20de\%20Desenvolvimento/. Acesso em: 22 mar. 2003.

27 LACERDA, N.; ZANCHETI, S.M.; DINIZ, F. Planejamento metropolitano no Brasil: uma proposta de conservação urbana e territorial. Recife: CECIUFPe, 1998. Disponível em: http://www.ceci-br.org/Textos/. Acesso em: 22 mar. 2003.

28 LANDI, F.R. (coord.) Indicadores de ciência, tecnologia e inovação em São Paulo, 2001. São Paulo: FAPESP, 2002.

29 LEFEBVRE, H. O direito à cidade. Tradução de Rubens Eduardo Frias. São Paulo: Centauro, 2001. Título original: Le droit à la ville.

30 LONDRINA TECNÓPOLIS. Os segmentos econômicos de Londrina e região: análise das potencialidades e problemas visando a estruturação de um pólo de inovação tecnológica. 1. ed. Londrina: ADETEC, 2001.

31 LUNDVALL, B.A. Innovation policy and knowledge management in the learning economy. Aalborg, Dinamarca: Department for Business Studies, Aalborg University, 2000a. Disponivel em:

<http://in3.dem.ist.utl.pt/downloads/cur2000/papers/>. Acesso em: 01 nov. 2002.

32 LUNDVALL B.A.; JOHNSON, B. Promoting innovation systems as a response to the globalising learning economy. In: CASSIOLATO, J.E.; LASTRES, H.M.M. (Coord.) Arranjos e sistemas produtivos locais e as novas 
políticas de desenvolvimento industrial e tecnológico: estudos

temáticos: nota técnica 4. Rio de Janeiro: IE/UFRJ, 2000b. Disponível em: $<$ http://www.ie.ufri.br/gei/ativid/projetos/gil/public/public3.htm>. Acesso em: 01 nov.2002.

33 LUNDVALL, B.A. Innovation policy and knowledge management in the learning economy. In: $4^{\text {th }}$ INTERNATIONAL CONFERENCE ON TECHNOLOGY POLICY AND INNOVATION. August 28-31, 2000c, Curitiba. Book of Abstracts... Curitiba: CITS/PUCPR/IBQP-PR/TECPAR/PARANA CLASSE MUNDIAL, 2000.

34 MARTINEAU, Y.; POITRAS, C.; TREPANIER, M. Les agglomérations scientifiques et technologiques. Québec, Canadá: Institut National de la Recherche Scientifique-Urbanisation, Université du Québec,1999.

35 MASANO T. São Paulo Global. Exame, edição 745, no 6, 2001.

36 MAXIMINIANO, A.C.A. Administração de projetos: como transformar idéias em resultados. São Paulo: Atlas, 1997.

37 Medeiros, J. A., medeiros, L. A., MARTINS, T., PeRILO, S. Pólos, Parques e Incubadoras - A Busca da Modernização e Competitividade. Brasilia: CNPq/IBICT/SENAI, 1992.

38 MEDEIROS, J. A. Incubadoras de Empresas: Lições da Experiência Internacional. In: XIX SIMPÓSIO DE GESTÃO DA INOVAÇÃO TECNOLÓGICA, 1996, São Paulo. Anais... São Paulo: USP/PGT/FIA/PACTo, 1996a.

39 MEDEIROS, J.A. Pólos científicos, tecnológicos e de modernização. TECBAHIA Revista Baiana de Tecnologia, v.11, n. 1, p. 11-25, 1996b.

40 MEGACITIES. Megacities 2000 Foundation, 2001. Apresenta informações e textos sobre desenvolvimento das megacidades globais. Disponível em: http://<http://www.megacities.nl/foundation.htm . Acesso em 20 nov. 2001.

41 MOTTA, D. M. Dinâmica demográfica e rede urbana. In: FORUM INTEGRAÇÃO DE COMPETÊNCIAS E DESENVOLVIMENTO REGIONAL. São José do Rio Preto: PMSJRP, nov. 2001. Disponivel em: http://www.siriopreto.org.brl. Acesso em 22 mar. 2003.

42 MURPHY, Z. Parque Tecnológico de Stanford: os próximos cinqüenta anos. In: GUEDES, M.; FORMICA, P. (Ed.) A economia dos parques tecnológicos. Rio de Janeiro: ANPROTEC, p. 3-24, 1997. 
43 MYERS, M.D. Qualitative Research in Information Systems. Disponivel em: $<$ http://www.auckland.ac.nz/msis/>. Acesso em 20 dez. 2002.

44 NAISBITT, J. Paradoxo global. Tradução de Ivo Korytowski. Rio de Janeiro: Campus; São Paulo: Publifolha, 1999. Título original: Global paradox.

45 NONAKA, I. A empresa criadora de conhecimento. In: HAVARD BUSINESS REVIEW (Ed.). Gestão do Conhecimento. Tradução de Afonso Celso da Cunha Serra. Rio de Janeiro: Campus, 2000. p. 27-49. Título original: On knowledge management.

46 NÚCLEO DE GESTÃO DO PORTO DIGITAL. Plano bi-anual 2001-2002: revisão 2002. Recife: PORTO DIGITAL, 2002. Disponivel em: $<$ http://www.portodigital.org>. Acesso em: 21 jan. 2003.

47 OHMAE, K. O fim do estado-nação. Tradução de Ivo Korytowski. Rio de Janeiro: Campus; São Paulo: Publifolha, 1999. Título original: The end of the Nation state.

48 PADETEC. Relatório institucional referente às atividades do PADETEC no ano 2000. Fortaleza, 2001.

49 PAREJO, M., SANTOS, S. A. Parques Tecnológicos: uma análise comparativa de experiências consolidadas de países desenvolvidos. São Paulo: Universidade de São Paulo - Faculdade de Economia e Administração, 1992.

50 PEREIRA, J.C.R. Análise de Dados Qualitativos - Estratégias Metodológicas para as Ciências da Saúde, Humanas e Sociais. São Paulo: Editora Universidade de São Paulo, 1999.

51 PLATE, K. Reinventing science parks. In: V WORLD CONFERENCE ON SCIENCE PARKS, October 29 to 31, 1996, Rio de Janeiro. Proceedings...Rio de Janeiro: UFRJ, 1996, p. 358-364.

52 PLONSKI, G.A. A cooperação empresa-universidade: antigos dilemas, novos desafios. Revista USP. n. 25, p. 32-41, 1995.

53 PLONSKI, G.A. Cooperação empresa-universidade no Brasil: um novo balanço prospectivo. In: INSTITUTO BRASILEIRO DE INFORMAÇÃO EM CIÊNCIA E TECNOLOGIA (Coord.) Interação universidade empresa. Brasília: IBICT, p. 9-23, 1998.

54 PLONSKI, G.A. Cooperação universidade-empresa: um desafio complexo. Revista de Administração. v. 34, n. 4, p. 5-12, 1999. 
55 PLONSKI,G.A. Questões tecnológicas na sociedade do des(conhecimento). In: SANTOS, L.W.; ICHIKAWA, E.Y.; SENDIN, P.V.; CARGANO, D.F. (Org.) Ciência, tecnologia e sociedade: o desafio da interação. Londrina: IAPAR, 2002. p. 83-99.

56 POPPER, K.R. A lógica da pesquisa científica. Tradução de Leônidas Hegenberg e Octanny Silveira da Mota. 2.ed. São Paulo: Editora Cultrix Ltda., 1974. Título original: The logic of scientific Discovery.

57 PORTER, M. E. A vantagem competitiva das nações. Tradução Waltensir Dutra. Rio de Janeiro: Campus, 1989. Título original: The competitive advantage of nations.

58 PORTO ALEGRE TECNÓPOLE. Termo de referência. Porto Alegre: Prefeitura Municipal de Porto Alegre, 1995.

59 PREFEITURA MUNICIPAL DE SÃO PAULO. Programa desenvolvimento local. São Paulo: Prefeitura Municipal de São Paulo, 2002.

60 RIBEIRO, R.P.; RIBEIRO, O.C.; VASCONCELOS, J.R.P.; GUIMARÃES, P.M. Projetos de captação de recursos para organizações de P\&D: conceitos, metodologias e informações básicas. Brasília: EMBRAPA, 1998.

61 ROGERS, P.; COQUEREAUMONT, M.; HOLTZ, P. Performance monitoring indicators: a handbook for task managers. Washington, D.C., EUA: The World Bank, May, 1996. Disponível em:

<http://www.worldbank.org/html/opr/pmi/maintx.html>. Acesso em: 31 jan. 2003.

62 ROLNIK, R. O que é cidade. São Paulo: Brasiliense, 1995, p.84.

63 ROLNIK, R. Governar as metrópoles: dilemas da recentralização. São Paulo em Perspectiva, v. 14, n. 4, p.83-90, out. 2000.

64 ROLNIK, R. São Paulo. São Paulo: Publifolha, 2001.

65 ROLNIK, R. Zona Leste de São Paulo enfrenta novo milênio. Pesquisa FAPESP, n. 55, jul. 2000. Disponivel em: <www.fapesp.br/human55.htm>. Acesso em: 10 nov. 2002.

66 SALOMÃO, J. R. As Incubadoras de Empresas pelos seus Gerentes - Uma Coletânea de Artigos. Brasília: ANPROTEC, 1998.

67 SANTOS, L.W.; ICHIKAWA, E.Y. CTS e a participação pública na ciência. In: SANTOS, L.W.; ICHIKAWA, E.Y.; SENDIN, P.V.; CARGANO, D.F. (Org.) 
Ciência, tecnologia e sociedade: o desafio da interação. Londrina: IAPAR, p. 239-273, 2002.

68 SANTOS, R.C.B. Campinas como centro produtor e irradiador de alta tecnologia na estrutura do espaço urbano regional. Scripta Nova, Barcelona, Espanha: Universidad de Barcelona, 2000.

69 SANZ, L. Parques científicos y tecnológicos: breve visión panorámica de sus modelos y tendencias In: VIII SEMINÁRIO DE PARQUES TECNOLÓGICOS E INCUBADORAS DE EMPRESAS. 1998, Belo Horizonte. Anais... Belo Horizonte: ANPROTEC, 1998.

70 SANZ, L. El papel de los parques tecnológicos en la economía del conocimiento: granjas del saber. Málaga: IASP, 2001.

71 SAXENIAN, A. Culture and competition in Sillicon Valley and Route 128. Cambridge, Massachussets, EUA: Havard University Press, 1996.

72 SCHIFFER, S. R. Os impactos da globalização sobre São Paulo. Revista Pesquisa Fapesp. ed. 23. ago. 1997.

73 SCOTT, A. Global city-regions In: CONFERENCE ON GLOBAL CITYREGIONS. Los Angeles, 1999. Theme paper/

74 SILVA, C.G.; MELO, L.C.P. Ciência, tecnologia e inovação: desafio para a sociedade brasileira- Livro Verde. Brasília: Ministério da Ciência e Tecnologia \& Academia Brasileira de Ciências, 2001.

75 SILVA, G.P.A. Science parks: achieving client satisfaction and improving synergies through urban design. In: $V$ WORLD CONFERENCE ON SCIENCE PARKS. October 29-31, 1996, Rio de Janeiro. Proceedings... Rio de Janeiro: AURRP/IASPIANPROTEC, 1996.

76 SPOLIDORO, R. The paradigm transition theory: a tool for guiding technopolitan transformations. In. V WORLD CONFERENCE ON SCIENCE PARKS. October 29-31, 1996, Rio de Janeiro. Proceedings... Rio de Janeiro: AURRP/IASP/ANPROTEC, 1996.

77 SPOLIDORO, R. A sociedade do conhecimento e seus impactos no meio urbano. In: PALADINO, G.G.; MEDEIROS, L.A. (Org.) Parques tecnológicos e meio urbano: artigos e debates. Brasília: ANPROTEC, 1997.

78 SPOLIDORO, R. Habitats de inovação e empreendedores: agentes de transformação das estruturas sociais. TECHBAHIA Revista Baiana de Tecnologia, v. 14, n. 3, p. 9-21, 1999. 
79 SPOLIDORO, R. Uma metodologia inovadora de desenvolvimento regional. Brasília: NEOLOG Consultores Associados Ltda., 2000. Apostila.

80 STAL, E. Cooperação Institucional Universidade-Empresa.In: SEBRAE/RS (Ed.) Série Tecnologia para a Competitividade. Porto Alegre: SEBRAE/RS, v. 2, 1998.

81 STIGLITZ, J.E. A globalização e seus malefícios: a promessa nãocumprida de benefícios globais. Tradução de Bazán Tecnologia e Lingüística. São Paulo: Futura, 2001. Título original: Globalization and its discontents.

82 TAGUSPARK. Catálogo 2001. Oeiras, Portugal: TAGUSPARQUE, 2001.

83 TERRA, J. C. C. Gestão do conhecimento: o grande desafio empresarial: uma abordagem baseada no aprendizado e na criatividade. São Paulo: Negócio Editora, 2000.

84 THIOLLENT, M. Metodologia da pesquisa-ação. 11.ed. São Paulo: Cortez Editora, 2002.

85 UNCHS. United Nations Centre for Human Settlements (Habitat). Apresenta texto sobre as cidades do mundo. 2001. Disponivel em: http://www.unchs.org/. Acesso em 20 nov. 2001.

86 VEDOVELLO, C. Aspectos relevantes de parques tecnológicos e incubadoras de empresas. Revista do BNDES, v. 7, p.273-300, 2000.

87 VEDOVELLO, C. Parques tecnológicos e a interação universidade-indústria. In: XIX SIMPÓSIO DE GESTÃO DA INOVAÇÃO TECNOLÓGICA. 22-25 out. 1996. São Paulo. Anais... São Paulo: USP/PGT/FIA/PACTo, p. 384-398, 1996.

88 VEDOVELLO, C. Science parks and university-industry interaction: geographical proximity between the agents as a driving force. Technovation, v. 17, n. 9, p. 491-502, 1997.

89 VIALE, R.; CAMPODALL'ORTO; S. An evolutionary Triple Helix to strengthen academy-industry relations: suggestions from European regions. Science and Public Policy. v. 29, n. 3, 2002.

90 WILHEIM, J. O arquiteto faz seus comentários sobre a aprovação do Plano Diretor de São Paulo. set. 2002. Disponível em: http://www.fortalsampa.hpg.ig.com.br/pdnews001.htm. Acesso em: 23 mar. 2003. 
91 ZOUAIN, D.M., PLONSKI, G.A. Technology Park of Sao Paulo - building up a model to metropolitan regions of Sao Paulo State. In: $11^{\text {th }}$ INTERNATIONAL ASSOCIATION OF MANAGEMENT OF TECHNOLOGY (IAMOT) CONFERENCE. March 10-14, 2002. Miami Beach, Florida, USA. Proceedings... Miami, Florida: IAMOT, 2002. CD-ROM.

92 ZOUAIN, D.M.; PLONSKI, G.A.; RODRIGUES, C.; ROGERO, J.R. Núcleo do Parque Tecnológico de São Paulo - um "habitat" para promoção da inovação tecnológica na empresa. In: CONGRESSO ABIPTI 2002. 22-24 maio 2002. Curitiba, Paraná. Anais... Brasília: ABIPTI, 2002. CD-ROM.

93 ZOUAIN, D.M.; PLONSKI, G.A.; ROGERO, J.R. Parque Tecnológico de São Paulo - modelo de políticas públicas para aproximação de atores do sistema local de inovação. In: WORLD CONFERENCE ON BUSINESS INCUBATION - RIO 2001. October 23-26, 2001. Rio de Janeiro. Proceedings... Rio de Janeiro: COPPE/UFRJ/ANPROTEC/SEBRAE, 2001. CD-ROM.

94 ZOUAIN, D.M.; PLONSKI, G.A.; ROGERO, J.R.; VEDOVELLO, C. The technology park of São Paulo - a Project to stimulate the local knowledgebased innovation system. In: $4^{\text {th }}$ TRIPLE HELIX CONFERENCE. November 69, 2002. Copenhagen, Dinamarca. Proceedings... Copenhagen: The Triple Helix Conference Series, 2002.

95 ZOUAIN, D.M.; ROGERO, J.R.; PLONSKI, G.A. Parque Tecnológico de São Paulo - construindo um modelo para regiões metropolitanas. In: XXII SIMPÓSIO DE GESTÃO DA INOVAÇÃO TECNOLÓGICA. 6-8 nov. 2002. Salvador, Bahia. Anais...São Paulo: Núcleo de Política e Gestão Tecnológica da Universidade de São Paulo, 2002. CD-ROM.

96 ZOUAIN, D.M.; SILVA, L.L.C.; PONTES, J.A.P.; ROGERO, J.R.; PLONSKI, G.A. Implantação de um parque tecnológico na cidade de São Paulo - as primeiras iniciativas. In: X SEMINÁRIO NACIONAL DE PARQUES TECNOLÓGICOS E INCUBADORAS DE EMPRESAS E VIII WORKSHOP ANPROTEC. 22-25 ago. 2000. Belém, Pará. Anais...Belém:

ANPROTEC/SEBRAE/UFPA/FADESP, 2000. CD-ROM.

97 ZWINGLE, E. Megacidades - o futuro das metrópoles. National Geographic Brasil. p. 108-133. nov. 2002. 


\section{BIBLIOGRAFIA RECOMENDADA}

1 ABETTI, P.A. Infrastructure for technological entrepreneurship. In: THIRD BEIJING INTERNATIONAL CONFERENCE ON TECHNOLOGICAL INNOVATION AND ENTREPRENEURSHIP DEVELOPMENT. 8-12 May 1990. Beijing. Proceedings...

2 ALMEIDA, A.M.; MORAIS, D. Os fundos setoriais - financiamento e desenvolvimento de pesquisas nas instituições de ensino superior. Brasília: FUNADESP, 2002.

3 BRESSAN, A.; DISTLER, C. O mundo de amanhã. Tradução de Isabel St. Aubyr. Lisboa: Publicações Dom Quixote Ltda., 1989.

4 CALOGHIROU, Y.; VONORTAS, N.S.; IOANNIDES, S. Science and technology policies towards research joint ventures. Science and Public Policy. v. 29, n. 2, p. 82-94, 2002.

5 CASTELLS, M. O poder da identidade. Tradução de Klauss Brandini Gerhardt. São Paulo: Editora Paz e Terra S.A., 2001. Título original: The power of identity.

6 CASTRO, C.M. Estrutura e apresentação de publicações científicas. São Paulo: Editora McGraw-Hill do Brasil Ltda., 1976.

7 CHUNG, S. Catching up through international linkages: science, technology and the Korean experience. Science and Public Policy. v. 29, n. 6, p. 431437, Dec. 2002.

8 COMMISSARIAT GENERAL DU PLAN. Recherche et innovation: le temps des réseaux : rapport du groupe " recherche, technologie et compétitivité ». Paris : La Documentation Française, 1993.

9 CRUZ, C.H.B. A universidade, a empresa e a pesquisa que o país precisa. Parcerias Estratégicas. n. 8, p. 5-30, 2000.

10 EMMANUEL, A. Technologie appropriée où technologie sousdéveloppée? Paris : Institut de Recherche et d'Information sur les Multinationales. 1981.

11 FAGGION, G.A.; BALESTRIN, A.; WEYH, C. Geração de conhecimento e inteligência estratégica no universo das redes interorganizacionais. Revista Inteligência Empresarial. n. 12, jul. 2002. 
12 GERL, E. Bricks \& Mortar: renovating or building a business incubation facility. Athens, Ohio: NBIA Publications, 2000.

13 HAMEL, G. Bringing Silicon Valley Inside. Harvard Business Review, p. 7184, September-October 1999.

14 HARVARD BUSINESS REVIEW. Empreendedorismo e estratégia. Tradução de Fábio Fernandes. Rio de Janeiro: Campus. 2002. Título original: Harvard business review on entrepreneurship.

15 HARVARD BUSINESS REVIEW. Inovação na prática. Tradução de Fábio Fernandes. Rio de Janeiro: Campus. 2002. Título original: Harvard business review on innovation.

16 HSUEH, L.M.; LIN, A-L; WANG, S.W.; OKRASA, G. (ed.) White paper on small and medium enterprises in Taiwan - 2001. Taiwan: Small and Medium Enterprise Administration/Ministry of Economic Affairs, 2001.

17 IGAMI, M.P.Z.; ZARPELON, L.M.C. Guia para elaboração de dissertações e teses: preparado para orientação dos alunos de Pós-Graduação do IPEN. São Paulo: IPEN, 2002.

18 JONASH, R.S.; SOMMERLATTE,T. O valor da inovação: como as empresas mais avançadas atingem alto desempenho e lucratividade. Tradução de Flávia Beatriz Rössler. Rio de Janeiro: Campus, 2001. Título original: The innovation premium.

19 LIPSCOMB,M.; MCEWAN,A.M. Effective technology transfer intervention methods. The Institution of Electrical Engineers. London, UK: IEE, 2002.

20 MARTINS, J.; CELANI, M.A.A. Subsídios para redação de tese de mestrado e de doutorado. 2.ed. São Paulo: Cortez \& Moraes Ltda., 1979.

21 MEYER-KRAHMER, F. Government promotion of linkages between research institutions and industry in the Federal Republic of Germany. In: INTERNATIONAL SEMINAR ON INSTITUTIONAL LINKAGES IN TECHNOLOGICAL DEVELOPMENT: UNIVERSITIES, R\&D INSTITUTES, PRODUCTIVE SECTOR AND FINANCE. 25-28 November 1985. São Paulo. Apostila...São Paulo: Secretariat of Industry, Commerce, Science and Technology of the State of Sao Paulo/United Nations Financing System for Science and Technology for Development, 1985.

22 MIT/BANKBOSTON The impact of innovation. Massachusetts:

BankBoston/MIT, 1997. 
23 MIT Massachusetts Institute of Technology: facts 2002. Cambridge, Massachusetts: MIT, 2002.

24 MOLINA-MORALES, F.X.; HOFFMANN, V.E. Aprendizagem através de redes sociais: o efeito da proximidade geográfica. Revista Inteligência Empresarial. n. 12, jul. 2002.

25 NEGROPONTE, N. Creating a culture of ideas. Technology Review. Feb. 2003.

26 PAULO, F; CASTRO, G. Sistemas de inteligência competitiva: apoio estratégico aos clusters. Revista Inteligência Empresarial. n. 11, abr. 2002.

27 PEREIRA, J.C.R. Análise de Dados Qualitativos - Estratégias Metodológicas para as Ciências da Saúde, Humanas e Sociais. São Paulo: editora Universidade de São Paulo, 1999.

28 PEREIRA, T.S. International dimension of research in Portugal: the European research area and beyond. Science and Public Policy. v. 29, n. 6, p. 451461, Dec. 2002.

29 RICE, M.P.; MATTHEWS, J.B. Growing new ventures, creating new jobs: principles\&practices of successful business incubation. Westport, Connecticut, London: Quorum Books, 1995.

30 ROSENFELD, S.A. Just clusters: economic development strategies that reach more people and places - a synthesis of experiences. Carrboro, North Carolina: Regional Technology Strategies, Inc., Sep. 2002.

31 RUIZ, M. S. (coord.) Os segmentos econômicos de Londrina e região: análise das potencialidades e problemas visando a estruturação de um pólo de inovação tecnológica. Londrina: ADETEC, 2001.

32 SAENZ, T.W.; GARCIA CAPOTE, E. Ciência, inovação e gestão tecnológica. Brasília: CNI/IEL/SENAI/ABIPTI, 2002.

33 SAXENIAN, A. Bangalore: The Silicon Valley of Asia? Disponivel em: $<$ http://www-dcrp.ced.ber.../Bangalore\%20-\%20The\%20Silicon\%20Valley\%200f\%20Asia.htm>. Acesso em: 03 nov. 2002.

34 SEITZER, D. Technology transfer-a flexible link between research, university and industry. European Journal of Engineering Education. v. 24, n. 2, p. 139-149, 1999. 
35 SILVA, C.G.; MELO, L.C.P. (Coord.) Ciência, tecnologia e inovação: desafio para a sociedade brasileira - Livro Verde. Brasília: Ministério da Ciência e Tecnologia/Academia Brasileira de Ciências. 2001.

36 SIMMIE, J.; KIRBY, M. Innovation and the theoretical bases of technopole planning. Progress in Planning. v. 49, n. 3/4, p. 159-197, 1998.

37 SIQUEIRA, J.O. Características fundamentais de uma tese de doutorado em ciências sociais. Disponível em: <http://www.hottopos.com./convenit2/siq2.htm>. Acesso em: 30 nov. 2002.

38 STEIN, J. A. Globalisation, science, technology and policy. Science and Public Policy. v. 29, n. 6, p. 402-408, Dec. 2002.

39 STEIN, J. A. Science, technology and European foreign policy: European integration, global interaction. v. 29, n. 6, p. 463-477, Dec. 2002.

40 TORNATZKY, L.G.; WAUGAMAN, P.G.; GRAY, D.O. Innovation U.: new university roles in a knowledge economy. South Carolina: Southern Growth Policies Board. 2002.

41 VACCAREZZA, L.S. Ciência, tecnologia e sociedade: o estado da arte na América Latina. In: SANTOS, L.W.; ICHIKAWA, E.Y.; SENDIN, P.V.; CARGANO, D.F. (Org.) Ciência, tecnologia e sociedade: o desafio da interação. Londrina: IAPAR, 2002. p. 43-79.

42 VEDOVELLO, $C$. Science Parks and the university-industry links: a case study of the Surrey Research Park. Brighton, U.K.: SPRU/University of Sussex, 1995.

43 WAGNER, C.S. The elusive partnership: science and foreign policy. Science and Public Policy. v. 29, n. 6, p. 409-417, Dec. 2002.

44 WUDKA, J. The Scientific Method. Disponivel em: <http://phyun5.ucr.edu/ wwudka/Physics7/Notes_www/node6.html>. Acesso em: 30 nov.2002.

45 ZAKY, A.A.; EL-FAHAN, M.M. The university-industry gap and its effect on research and development. Engineering Science and Education Journal. P. 122-125, June 1998. 